Zuzanna Bogumił /

Małgorzata Głowacka-Grajper

\title{
Milieux de mémoire in Late Modernity
}

Local Communities, Religion and Historical Politics

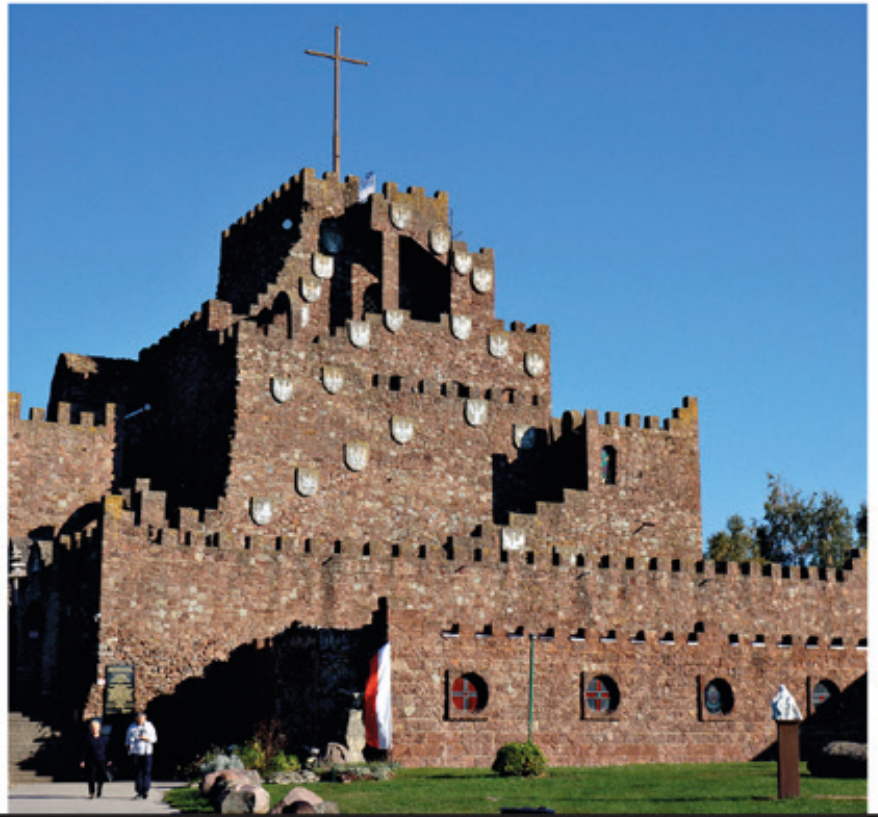




\section{Zuzanna Bogumił / \\ Małgorzata Głowacka-Grajper}

\section{Milieux de mémoire in Late Modernity}

This book shows how vernacular communities commemorate their traumatic experiences of the Second World War. Despite having access to many diverse memory frameworks typical of late modernity, these communities primarily function within religious memory frameworks. The book also traces how they reacted when their local histories were incorporated into the remembrance practices of the state. The authors draw on case studies of four vernacular communities, notably Kałków-Godów, Michniów, Jedwabne and Markowa, to argue that it is still possible in the Polish countryside to discover milieux de mémoire. At the same time, they show that the state not only uses local histories to bolster its moral capital in the international arena, but also in matters of domestic policy.

\section{The Authors}

Zuzanna Bogumił is Assistant Professor at the Maria Grzegorzewska University in Warsaw. She works on the religious dimension of memory. Her recent publications focus on rediscovery of Russia's repressive past and representation of the Second World War in Eastern European museums.

Małgorzata Głowacka-Grajper is Assistant Professor at the Institute of Sociology at the University of Warsaw. She has published several articles and books on ethnic minorities in Poland, ethnic identity and social memory in post-Soviet countries. 
Milieux de mémoire in Late Modernity 


\title{
GESCHICHTE - ERINNERUNG - POLITIK STUDIES IN HISTORY, MEMORY AND POLITICS
}

Herausgegeben von / Edited by Anna Wolff-Powęska \& Piotr Forecki

\author{
Bd./Vol. 24
}


Zuzanna Bogumił / Małgorzata Głowacka-Grajper

\section{Milieux de mémoire in Late Modernity \\ Local Communities, Religion and Historical Politics}




\section{Bibliographic Information published by the Deutsche Nationalbibliothek}

The Deutsche Nationalbibliothek lists this publication in the Deutsche

Nationalbibliografie; detailed bibliographic data is available in the internet at http://dnb.d-nb.de.

\section{Library of Congress Cataloging-in-Publication Data}

A CIP catalog record for this book has been applied for at the Library of Congress.

Cover image: $\odot$ Dariusz Bogumił

This project was supported by the National Science Centre in Poland grant no. DEC-2013/09/D/HS6/02630.

English translation and editing by Philip Palmer

Reviewed by Marta Kurkowska-Budzan, Jagiellonian University

ISSN 2191-3528

ISBN 978-3-631-67300-3 (Print)

E-ISBN 978-3-653-06509-1 (E-PDF)

E-ISBN 978-3-631-70830-9 (EPUB)

E-ISBN 978-3-631-70831-6 (MOBI)

DOI $10.3726 / \mathrm{bl} 5596$

\section{PETER LANG

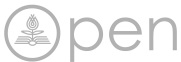

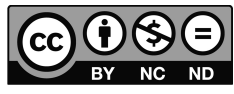

Open Access: This work is licensed under a Creative Commons Attribution Non Commercial No Derivatives 4.0 unported license. To view a copy of this license, visit https://creativecommons.org/licenses/by-nc-nd/4.0/

(c) Zuzanna Bogumił / Małgorzata

Głowacka-Grajper, 2019

Peter Lang -Berlin · Bern · Bruxelles · New York ·

Oxford $\cdot$ Warszawa $\cdot$ Wien

This publication has been peer reviewed.

www.peterlang.com 


\section{Acknowledgments}

This book is the product of a long period of cooperation fueled by our common desire to comprehend the crucial influence religious modes of commemoration exert on meaning attributed to the past, and in particular to twentieth-century history. We have repeatedly encountered such religious modes of commemoration over the course of field trips undertaken in Poland over many years. In fact, crosses, memorial stones engraved with religious symbols, churches, and sanctuaries containing epitaphs, commemorative plaques, sacred figures, or stained-glass windows form an integral part of the Polish cultural landscape. These memory markers became such a frequent topic of discussion during the regular meetings we organized to reflect on our research that we eventually decided it would be worth investigating the issue of religious commemoration systematically. We achieved this by developing a project titled Milieux de mémoire in Eastern Europe - the Polish Case Study, which the National Science Center generously agreed to fund ${ }^{1}$. The project was coordinated by Zuzanna Bogumił and administered by the Maria Grzegorzewska University in Warsaw. Małgorzata Głowacka-Grajper and Marta Karkowska were the main investigators in this project. We would like here to offer our very warm gratitude to Marta Karkowska for the many years she devoted to the project, carrying out research in Kałków-Godów, Michniów, and Markowa, conducting analytical work, taking part in discussions and critically reading each chapter of the book, all of which enabled her to offer us very valuable comments that helped us put the finishing touches to the manuscript. Our analysis of articles that Marta Karkowska published about Michniów ${ }^{2}$ and the manuscript she prepared for another article on Markowa were an important point of departure for us when we started writing the chapters of this book devoted to these places.

1 Project no 2013/09/D/HS6/02630 (2014-2017). We write about the assumptions behind the project on the project website: www.milieuxdememoire.aps.edu.pl.

2 Marta Karkowska. "Międzypokoleniowe Transmisje pamięci. Na podstawie badań we wsiach świętokrzyskich.” [Intergenerational Memory Transmissions. Based on Research in Villages in the Holy Cross Region] Studia Socjologiczne, Vol. 222, 2016a, pp. 101-132; Marta Karkowska. "Pamięć społeczności lokalnej w jej publicznej i prywatnej odsłonie. Przykład Michniowa." [The Public and Private Memory of a Local Community] In: Przemiany kulturowe we współczesnej Polsce: ramy, właściwości, epizody, ed. Joanna Kurczewska. Warsaw: Wydawnictwo IFiS PAN, 2016b, pp. 376-401. 
We would not have been able to complete our research without the institutional support we received from the universities where we work. We would not only like to offer our heartfelt gratitude to the Maria Grzegorzewska University's ViceChancellors, first, Professor Jan Łaszczyk, then, Stefan Kwiatkowski, but also to its Vice-Chancellor for Science, Professor Jarosław Rola, and the Directors of the Institute of Sociology, first, Professor Elżbieta Tarkowka, then, Danuta DuchKrzystoszek, all of whom supported the project throughout its implementation. We would also like to express our gratitude to Professor Andrzej Waśkiewicz, Director of the Institute of Sociology at the University of Warsaw, and Renata Włoch, Director of Academic Affairs at the same institute, and Professor Andrzej Rychard, Director of the Institute of Philosophy and Sociology at the Polish Academy of Sciences (PAN), for their support and assistance with the practical aspects of our research.

In October 2014, an international conference titled Memory and Religion in Central and Eastern Europe was held at the Maria Grzegorzewska University. Those who attended shared their reflections on the influence religion has exerted on the manner in which twentieth-century history is commemorated. At this juncture, we would like to offer our most sincere gratitude to Dominique Moran, Jay Winter, Mariusz Sulkowski, Matilda Mroz, Tatiana Voronina, Piotr Kwiatkowski, Agnieszka Halemba, Marta Łukaszewicz, Tomasz Zarycki, Joanna Derdowska, and Mārtiņš Kaprāns for their thought-provoking contributions to the seminar, inspiring presentations, and valuable comments, all of which enabled us to refine our theoretical framework for the project.

From 2014 to 2017, we conducted research throughout Poland, aided by Aleksandra Ciecieląg, Ewa Szczecińska-Musielak, Karolina Obrębska, Aleksandra Jarosz, and first and foremost, Marta Karkowska. Without their devoted assistance, we would not have been able to collect the material we needed. We would also like to thank the students who took part in activities exploring links between memory and religion - led by Zuzanna Bogumił at the Maria Grzegorzewska University and Małgorzata Głowacka-Grajper at the Institute of Sociology at the University of Warsaw (UW) from 2014 to 2015 - for assisting in the collection of materials and contributing to valuable discussions.

Our conception for the book crystallized over a number of conferences and academic seminars. We would like to express our special gratitude to Professor Robert Traba for the valuable comments he offered during the presentation of our project at a seminar at the PAN Center for Historical Research in Berlin in October 2016. First and foremost, however, we would like to extend our gratitude to the participants of the Memory of Wartime Trauma in Local Communities seminar held during the University of Warsaw's Interdisciplinary Social Memory 
Laboratory in March 2017. It was at this point that the entire conception for the book was critically evaluated. The comments made at the time by Kamila Baraniecka-Olszewska, Małgorzata Wosińska, Anna Wylegała, and Karolina Wigura enabled us to refine our conception for the book, so we are extremely grateful for them.

We would also like to pass our words of gratitude on to Philip Palmer, who translated the Polish manuscript into English while taking care to ensure that the text would be understandable to the anglophone reader without any specialist knowledge of Polish history and culture. We would like also to acknowledge Marta Kurkowska-Budzan for her careful review of the book and very helpful comments, as well as Zofia Wóycicka, who read some parts of the book and left us very important remarks.

Finally, we would like to direct our words of gratitude and empathy towards our husbands, children, and parents, who provided their support and understanding while we were implementing our project and writing this book. In my role as project coordinator, I would like to thank Małgorzata Głowacka-Grajper and Marta Karkowska one more time for working with me on this project, their understanding, the support they provided, and, first and foremost, the inspiring conversations and endless discussions we had together. I would also like to offer my further gratitude to Małgorzata Głowacka-Grajper for working with me on this publication.

This book presents only some of the findings from research conducted within the framework of the Milieux de mémoire in Eastern Europe - the Polish Case Study project. Other project results have already been presented in the following articles: "Pamięć jako kapitał społeczności lokalnej. Narracje o Bitwie Warszawskiej 1920 roku w Radzyminie" [Memory as the Local Community Capital. Narratives of the Battle of Warsaw 1920 in Radzymin] by Małgorzata Głowacka-Grajper, "Zbrodnia katyńska. niespójna pamięć w kontekście miejsc pamięci o Katyniu na terenie Warszawy" [The Katyn Massacre. Incoherent Memory within the Context of Sites of Memory in Warsaw Commemorating Katyn] by Aleksandra Jarosz, "Muzeum ks. Jerzego Popiełuszki w Warszawie jako miejsce kształtowania tożsamości społecznej poprzez doświadczenie religijne" [The Jerzy Popiełuszko Museum in Warsaw as a Place for Shaping Social Memory through Religious Experience] by Karolina Obrębska, and "Miejsca pamięci i formy upamiętniania cywilnych ofiar rzezi warszawskiej Woli (sierpień $1944 \mathrm{roku}$ )" [Sites of Memory and Forms of Remembering the Civilian Victims of the Massacre in the Warsaw District of Wola] by Ewa Szczecińska-Musielak, all of which were published in a book titled Stare i nowe tendencje w obszarze pamięci społecznej [Old and New Tendencies within the Social Memory Sphere] edited by Zuzanna Bogumił and 
Andrzej Szpociński (Warszawa: Scholar, 2018); and also in the following scholarly articles: Marta Karkowska. "Międzypokoleniowe Transmisje pamięci. $\mathrm{Na}$ podstawie badań we wsiach świętokrzyskich" [Intergenerational Memory Transmissions. Based on Research in Villages in the Holy Cross Region]. Studia Socjologiczne, Vol. 222, 2016, pp. 101-132; Zuzanna Bogumił. "Pamięć religijna społeczności lokalnych - przykład Jedwabnego" [The Religious Memory of Local Communities - the Jedwabne Example]. Kultura i Społeczeństwo, Vol. 3, 2017, pp. 161-184; Zuzanna Bogumił. "Pamięć o konfliktach i dialogach Polaków z sąsiadami zapisana w kulturowym krajobrazie stolicy” [Memory of Poles' Conflicts and Dialogues with Their Neighbors within the Capital's Cultural Landscape]. In: Przemiany kulturowe we wspótczesnej Polsce: ramy, właściwości, epizody, ed. Joanna Kurczewska. Warsaw: Wydawnictwo IFiS PAN, 2016, pp. 402-426; Marta Karkowska. "Pamięć społeczności lokalnej w jej publicznej i prywatnej odsłonie. Przykład Michniowa" [The Public and Private Memory of a Local Community]. In: Przemiany kulturowe we wspótczesnej Polsce: ramy, właściwości, epizody, ed. Joanna Kurczewska. Warsaw: Wydawnictwo IFiS PAN, 2016, pp. 376-401; Zuzanna Bogumił. "The Blessed Jerzy Popiełuszko Museum in Warsaw: Between History and Religion” In: Cultures of History Forum (12.01.2018), URL: http:// www.culture-of-history.uni-jena.de//exhibitions/poland/the-blessed-jerzypopieluszko-museum-in-warsaw-between-history-and-religion/; Zuzanna Bogumił. "Polish Experiences of Dialogues about Difficult Past in XX Century with Neighboring Nations" In: Conflicted Past: Politicization of History in Europe and Asia, ed. Nobuya Hashimoto. Tokyo: Iwanami Shoten, 2018, pp. 135-163. 


\section{Contents}

List of Abbreviations

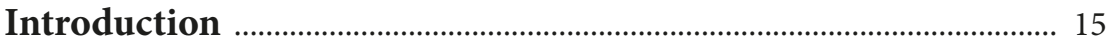

The Local Community in Late Modernity ......................................................... 21

The Second World War as a Key Event in Poland's Most Recent History ...... 23

The Global Turn Toward Moral Narratives ..................................................... 29

The Catholic Church and Religious Language Used for

Commemorating the National Past ................................................................. 34

Postwar Forms of Remembrance - a Time of Crosses and Shrines ....... 35

Forms of Remembrance of the 1980s and 1990s - a Time of

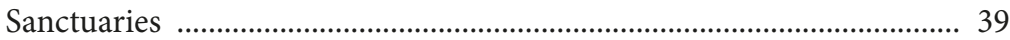

Forms of Remembrance in the Twenty-First Century - a Time of Narrative Projects .......................................................................................... 43

Research Methodology ............................................................................ 46

The Book's Structure ............................................................................... 48

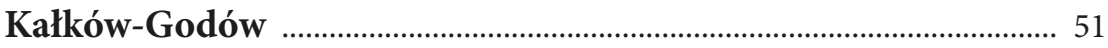

Kałków-Godów During the Second World War .............................................. 53

Vernacular Memory of the Second World War ............................................... 55

Local Controversies Connected with Memory of the Second

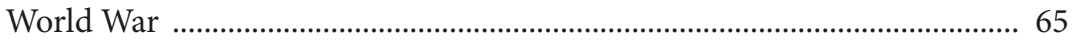

National Martyrdom in the Sanctuary Narrative ............................................ 67

Kałków-Godów as a Site of Memory for Peasants .......................................... 77

The Power of Religious Memory ……………………........................................ 82 
Michniów During the Second World War ...................................................... 88

The History of the Michniów Pacification's Memorialization .................... 90

The Memory of a Rural Community and Historical Policy .......................... 102

Controversies Relating to Narratives of Wartime Events ........................ 103

Controversies Surrounding Commemoration of the Pacification ........ 109

Anniversary Ceremonies: Between Local and National Memory ......... 117

The Transmission of Memory on a Local, National and Global Level ...... 119

Between Traditional and Modern Methods of Commemoration ............... 125

Jedwabne .......................................................................................... 127

Jedwabne During the Second World War ....................................................... 129

The Massacre of 10 July 1941 and Its Contemporary Interpretation ......... 138

Memory of the Massacre of Jews in Jedwabne up to 2001 ............................ 141

Jedwabne from 2000 to 2001 .......................................................................... 152

The Jedwabnians as a Parish Community ....................................................... 157

The PRL Monuments in Jedwabne ................................................................... 163

The "Jewish" Monument - a Lost Milieu of Memory? .................................. 167

Jedwabne's "Monument Therapy" - the Sybiraks Memorial ........................ 170

Stage Two of "Monument Therapy" - the Tomb of the Unknown

Soldier .................................................................................................. 174

The Jedwabnians' Post-Vernacular Memory ................................................... 178

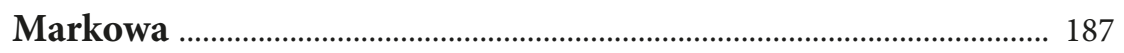

The History of Markowa ..................................................................................... 191

The Ulma Family ........................................................................................... 195

The Beginnings of the Ulmas' Commemoration ...................................... 198

Family Memory and the Ulmas' Commemoration ...................................... 208 
The Beginnings of Religious Commemoration - 2003: The Watershed Year

Between Religious and Secular Remembrance .......................................... 218

The Museum Memory Project and National Memory of the Ulmas ........ 224

The Meaning of Material Repositories for Memory of the Ulmas ............. 231

Not only the Ulmas - On the Polish Righteous ............................................ 233

The Religious and National Political Dimensions of Memory of the Ulmas

Conclusion 249

List of Figures 259

Bibliography 263

Note on Authors 283

Index 285 



\section{List of Abbreviations}

\begin{tabular}{|c|c|}
\hline AK & Armia Krajowa (Home Army) \\
\hline CBOS & $\begin{array}{l}\text { Centrum Badania Opinii Społecznej (Centre for Public Opinion } \\
\text { Research) }\end{array}$ \\
\hline IDO & $\begin{array}{l}\text { Institut für Deutsche Ostarbeit (Institute for German Work in } \\
\text { the East) }\end{array}$ \\
\hline IPN & Instytut Pamięci Narodowej (Institute of National Remembrance) \\
\hline MPRŻ & $\begin{array}{l}\text { Muzeum Polaków Ratujących Żydów podczas II Wojny Światowej } \\
\text { im. Rodziny Ulmów (Ulma Family Museum of Poles Saving Jews } \\
\text { during the Second World War) }\end{array}$ \\
\hline NKVD & $\begin{array}{l}\text { Komissariat Vnutrennikh Del (The People's Commissariat for } \\
\text { Internal Affairs) }\end{array}$ \\
\hline NSZ & Narodowe Siły Zbrojne (National Armed Forces) \\
\hline OZLP & $\begin{array}{l}\text { Okręgowy Zarząd Lasów Państwowych (District National Forest } \\
\text { Administration) }\end{array}$ \\
\hline OrPo & Ordnungspolizei (Order Police) \\
\hline PiS & Prawo i Sprawiedliwość (Law and Justice party) \\
\hline PSL & Polskie Stronnictwo Ludowe (Polish People’s Party) \\
\hline PRL & Polska Rzeczpospolita Ludowa (Polish People’s Republic) \\
\hline PTTK & $\begin{array}{l}\text { Polskie Towarzystwo Turystyczno-Krajoznawcze (Polish Tourist } \\
\text { and Sightseeing Society) }\end{array}$ \\
\hline ROPWiM & $\begin{array}{l}\text { Rada Ochrony Pamięci Walk i Męczeństwa (Council for the } \\
\text { Protection of Struggle and Martyrdom Sites) }\end{array}$ \\
\hline SL & Stronnictwo Ludowe (People’s Party) \\
\hline SiPo & Sicherheitspolizei (Security Police) \\
\hline SS & Schutzstaffel (Protective Echelon) \\
\hline UB & Urząd Bezpieczeństwa (Office of Security) \\
\hline UPA & Ukraińska Powstańcza Armia (Ukrainian Insurgent Army) \\
\hline USSR & $\begin{array}{l}\text { Soyuz Sovetskikh Sotsialisticheskikh Respublik (the Union of } \\
\text { Soviet Socialist Republics) }\end{array}$ \\
\hline $\mathrm{WiN}$ & Wolność i Niepodległość (Freedom and Independence) \\
\hline ZBOWiD & $\begin{array}{l}\text { Związek Bojowników o Wolność i Demokrację (Society of Fighters } \\
\text { for Freedom and Democracy) }\end{array}$ \\
\hline
\end{tabular}





\section{Introduction}

Shortly after the road from Warsaw to Pruszków passes the Warsaw Commuter Railway level crossing, a stone shrine containing a statue of the Virgin Mary emerges from a group of old trees in the village of Reguły in the Commune of Michałowice. A plaque over the alcove containing the statue bears the following inscription: "Lord, keep us from Famine, Fire and War". Below this inscription, the shrine's history has been clearly and carefully engraved: "The inhabitants of the Gromada of Reguły are erecting this memorial on the third anniversary of the victorious conclusion of the war as a votive offering expressing our gratitude to God for rescuing the village and its inhabitants from the extermination during the world war and Nazi occupation from 1939 to 1945 and that we may ask Christ the Lord and Our Lady Queen of Peace for Eternal Peace. 1948." The shrine has been well looked after and painted. It is decorated with immaculate, carefully-fastened colored ribbons. Freshly planted flowers grow within the enclosure partitioning off the sacred space and in pots placed around the statue of the Virgin Mary. Evidently, this place attracts regular, enthusiastic visitors. This is clear from the candles burning around the shrine and the new bench placed there in 2010 as part of a revitalization project. The shrine is located next to the commune office, which was built a few years ago, and an enormous parking lot. The course of the road was changed to accommodate the new office's construction, but the shrine was not moved. Instead, it stands where the village's inhabitants erected it in 1948. Even though it looks surreal surrounded by an old stand of trees that fails to integrate with space developed according to the rules of contemporary urban planning, it continues to "live on" as a site that attracts local residents celebrating holidays or gathering for religious rituals. Does this place prove the continued durability of milieux de mémoire?

Pierre Nora introduced the notion of lieux de mémoire into the social sciences and humanities, contrasting these sites of memory with milieux de mémoire, or environments of memory. However, he did not define what, in his view, these environments possessing real memory actually consisted of. Undoubtedly, Nora believed that such milieux no longer exist because they have been completely replaced in the contemporary world by sites of memory. Yet the existence of such environments of memory is illustrated, in his view, by primitive or archaic societies. He describes this type of memory as "an integrated, dictatorial memory - unself-conscious, commanding, all-powerful, spontaneously actualizing, a memory without the past that ceaselessly reinvents tradition, linking 
the history of its ancestors to the undifferentiated time of heroes, origins, and myth"3. It appears that it would not be possible to find such milieux containing real memory in modern Europe. However, Nora's notion inspired us to investigate the relations between the remnants of milieux de mémoire and the contemporary lieux de mémoire that had been taking their place. Sites of memory are a community's response to the feeling that their ties to the past and their traditions are being eroded and therefore need special places in space, ceremonies, books, and symbols to enable this community to remember what has happened to it over the years. The question then arises of how we can be sure that such a milieu used to exist ${ }^{4}$. Could it not in fact be a creation of the imagination constructed in opposition to what contemporary Europeans observe around themselves, a creation, in fact, that mythologizes life "in olden times"? If people do not remember now, they surely did in the past. If they have the feeling that things are changing suddenly now, they surely once had a feeling of permanency and lack of variability. On the other hand, such sites as the roadside shrine mentioned above show that certain past events live on in the memory of a community, irrespective of the passage of time. What is more, these memory markers outline the spatial dimension of a community's life while serving as memory rituals of a religious nature. Since similar shrines and their histories can be encountered at other sites in Poland, we became intrigued by the relation between allusion to the past (memory) and the religious aspect of life (along with the narrative, ritual, material, and spatial dimension of this).

At the outset, we want to emphasize that we believe that environments of memory (milieux de mémoire), as conceived by Pierre Nora, do not in fact exist in contemporary Poland. Nevertheless, we believe that local communities possess their own vernacular mode of remembering and commemorating the past. In fact, the increasing number of research projects being conducted in the Polish countryside have demonstrated the existence of such vernacular commemoration practices ${ }^{5}$. However, most authors perceive these vernacular

3 Pierre Nora, "Between Memory and History: Les Lieux de Mémoire." Representations, Vol. 26, 1989, p. 8.

4 Sabine Marschall, "Collective Memory and Cultural Difference: Official vs. Vernacular Forms of Commemorating the Past." Safundi. The Journal of South African and American Studies, Vol. 14, No. 1, 2013, p. 78.

5 See, for example: Mateusz Magierowski, "Between Dissonance and Convergence: The Dynamics of Interactions between Vernacular and Official (Non-) Memories of the Mass Murder of Germans by Poles in Nieszawa." Polish Sociological Review, Vol. 1(197), 2017, pp. 83-94; Mateusz Magierowski, “(A)symmetry of (Non-)memory. The Missed Opportunity to Work Through the Traumatic Memory of the Polish-Ukrainian Ethnic 
commemorations as mostly non-lieux de mémoire, that is, "sites whose past does not allow them to be completely negated (...), but which, for unarticulated reasons, are not-to-be-included in local history. Since an effort is being made to neutralize their meanings, they are not completely forgotten"6. These sites are, therefore, “accessible but invisible," as Roma Sendyka claims: "rather than a state of amnesia, we are dealing with a set of impulses - taking the form of a half-measure or homeopathic remedy - that preserve relations to the past while keeping it at a safe distance"7.

We believe that it would be risky to use the non-site of memory category, despite its intellectual appeal, to analyze vernacular forms of remembrance. The most important consideration for us is that if the non-site of memory is a homeopathic half-measure substituting for real commemoration, it means that there must be a non-homeopathic mode of remembrance that is completely genuine. But what form might this take? That of a monument? Postcolonial researchers have shown that the perception that secular monuments are the most efficient repositories of memory arose from the manner in which Western culture perceives processes of remembering and forgetting, so a perception of this nature should be deconstructed and reconsidered. As Sabine Marschall claims, vernacular memory, much like official memory, forms a society's collective memory but uses different markers and material objects to do this. Vernacular commemorations are strongly linked to grassroots traditions, since they include "a diverse range of collective memory practices, often highly localized, informal,

Conflict in Pawłokoma." East European Politics and Societies and Cultures, Vol. 30/4, 2016, pp. 766-784; Mateusz Magierowski, “'Trauma sprawców’ jako przedmiot społecznie kształtowanych procesów pamiętania i zapominania w społeczności lokalnej. Przypadek Gniewczyny." Studia Humanistyczne AGH, Vol. 13/3, 2014, pp. 247-258; Roma Sendyka, "Nie-miejsca pamięci i ich nie-ludzkie pomniki." Teksty Drugie, vol. 2, 2017, pp. 86-108; Lubańska, Magdalena. "Postmemory of Killings in the Woods at Dębrzyna (1945-46): a Post-Secular Anthropological Perspective." Ethnologia Polona, Vol. 38, 2018, pp. 15-45; Tomasz Rakowski, "Etnografia, pamięć, eksperyment: w stronę alternatywnej historii społecznej.” Teksty Drugie, Vol. 6, 2016, pp. 268-281.

6 Sendyka, Nie-miejsca pamięci, p. 88. For more on non-sites of memory, see: Roma Sendyka, "Pryzma - zrozumieć nie-miejsce pamięci (non-lieux de mémoire)." Teksty Drugie, Vol. 1/2, 2014, pp. 323-344; Mateusz Magierowski, "Historyczne, kulturowe i społeczne czynniki kształtujące społeczną (nie-) pamięć o zbrodniach popełnionych przez Polaków na przedstawicielach innych grup etnicznych w Gniewczynie i Pawłokomie." Sensus Historiae, Vol. XX, 2015, pp. 49-60.

7 Roma Sendyka, "Niepamięć albo o sytuowaniu wiedzy”, p. 264. 
spontaneous, ephemeral, community-based, or rooted in tradition, local custom, or popular culture"8. Marschall also stresses that the fact that there are no visible signs of commemoration need not mean that a local community has forgotten its past. Marschall references traditional South African commemoration practices to demonstrate that "grave sites are not necessarily physically marked or publicly visible. They exist primarily in communal memory; knowledge about them is rehearsed and transferred through oral tradition, notably poetry; specific taboos or rules of avoidance (hlonipha) govern the treatment of and access to such sites"'. What Marshall wants to stress most is that all vernacular commemorative practices stand in a symbiotic relationship with vernacular memory ${ }^{10}$. It should, therefore, be analyzed as such rather than through reference to monumental commemorations ${ }^{11}$.

In our opinion, the specific reference point which should be taken into consideration while analyzing vernacular memory in the Polish countryside is the Roman Catholic religion. As Antoni Sułek, a Polish sociologist who has conducted over 15 years of research on the Holocaust in his home region in Central-Eastern Poland, claims, "the spiritual atmosphere in a town or village is greatly inspired by its parish church" ${ }^{\prime 2}$. This is confirmed by our own research, whose findings we present in this book. Our research also shows that in the Polish countryside, it is still possible to discover memory based on a religious conception of the social order. Successive events can be permanently incorporated into memory

8 Marschall, "Collective Memory and Cultural Difference", p. 79.

9 Marschall, "Collective Memory and Cultural Difference", p. 84.

10 A good example of this kind of symbiotic relationship is memory of the genocide committed against the Roma and Sinti by the Nazis during the Second World War. Lech Mróz, a Polish anthropologist, explains that Roma and Sinti memory has a very vernacular framework. It may appear to outsiders that such memory has been forgotten, but in fact, the texture of this memory is redolent of its vernacular character. See Lech Mróz, "Niepamięć nie jest zapomnieniem. Cyganie-romowie a Holocaust." Przegląd Socjologiczny, Vol. 2, 2000, pp. 89-114. Examples of this kind of vernacular memory in Roma and Sinti communities and the processes of adjusting them to "the modern memory practices" are also presented in a book by Sławomir Kapralski titled Naród $z$ popiołów. Pamięć Zagłady a tożsamość Romów. Warsaw: Wydawnictwo Naukowe Scholar, 2012.

11 Paul Stangl, "The Vernacular and the Monumental: Memory and Landscape in Postwar Berlin." GeoJournal, 73(3), 2008, pp. 245-253.

12 Antoni Sułek, "Both Researcher and Second Generation Witness - On Rescuing Local Memory of the Holocaust in Poland." East European Politics and Societies and Cultures, 2018, DOI: $10.1177 / 0888325418798692$. 
of this type, thereby incorporating them in a memory sequence that defines a community's identity while remaining consistent with its notions of the world and the rules that prevail within it.

However, contemporary local communities do not live wholly within a world organized by religious thought exclusively managed by ecclesiastical institutions. On the contrary, each community functions within a state and encounters the various institutions of the state in question on a daily basis (from local authorities to the general education system). Apart from the narrative alluding to the religious tradition, there is another functioning narrative, a national narrative ${ }^{13}$ (though in Poland's case, these two narratives are sometimes closely interwoven). These communities also function in a globalized world where a system of swift information transferal (comprising the mass media or Internet) not only enables them to keep track of events from other parts of the world, but also to show the world what is happening in their part of the world. At the same time, there are globalized remembrance narratives that transcend the boundaries of the community from which they originate, a classic example of these being memory of the Holocaust, in particular its narratives and the way in which it uses the mass media $^{14}$.

Any investigation of the Polish cultural landscape will reveal this diversity of forms and remembrance narratives. However, it quickly becomes apparent that religious language maintains a continuous hold over both local and state national history remembrance practices, including the commemoration of the most recent twentieth-century history, such as the Second World War and the communist period. Our main focus of interest was in fact the predominance of religious language in these Second World War commemorative practices. While they were in power, the communist authorities attempted to create a secular, non-religious language for commemorating the war. As far as the communist regime was concerned, the war, which it perceived as an event legitimizing its power, demanded a new language of remembrance ${ }^{15}$. Despite the construction

13 For the analysis of different contexts in which local memory is shaped, see, for example, Jacek Nowak, Społeczne reguły pamiętania. Antropologia pamięci zbiorowej. Kraków: Nomos, 2011.

14 Michael Rothberg, Multidirectional Memory. Remembering the Holocaust in the Age of Decolonization. Stanford: Stanford University Press, 2009.

15 Joanna Wawrzyniak, Veterans, Victims, and Memory. The Politics of the Second World War in Communist Poland. Translated by Simon Lewis. Frankfurt a.M. [usw.]: Peter Lang, 2015; Marcin Zaremba, Komunizm, legitymizacja, nacjonalizm. Nacjonalistyczna legitymizacja władzy w komunistycznej Polsce. Warsaw: Wydawnictwo Trio, 2001. 
of memorial complexes and many smaller, secular memory markers, it is sites of memory of a religious nature that predominate in today's cultural landscape. Moreover, after 1989, there was a clear turn toward religious language of commemoration when the war was being remembered. The question of commemorating the war is all the more important because, as sociological studies show, memory of wrongs suffered during the Second World War exerts a key influence on the memory and identity of Poland's inhabitants ${ }^{16}$. The fact that the texture of this memory is increasingly religious in nature has become very significant.

In this book, we concentrate on showing how memory of the war is manifested within the vernacular environment and what functions it performs. We have chosen Kałków-Godów, Michniów, Jedwabne, and Markowa because these are villages or small towns located far away from large cities containing vernacular communities centered around a parish church. In all of these places, the Church plays a very important role, not only within the religious sphere but also within the domain of memory. The state or Church became interested in these places at various points, attempting to use them as a basis for the creation of their own national memory project, so we decided to investigate how a vernacular community reacts to the appearance of an external memory actor that begins creating a memorial on their land, based on the local history but alluding to Polish national history. We attempted to respond to a number of questions. How does a local community respond to a project possessing the status of a Polish national site of memory being created within its territory and to the vision of the past this project expresses? Are the commemorative structures a local community has erected in response to their own war experiences more important to them than the newly created "national" ones? What language, symbols, and narrative motifs are employed in vernacular memorials and those created for the nation as a whole and how do they interact? Moments of confrontation seemed to us to be important because they force a local community to act and articulate its arguments. No matter whether a community chooses to accept or reject an external interpretation of its past, every action it takes forces it to justify its decision verbally. Consequently, the actions local communities take and the arguments they evoke reveal their way of thinking about the past, what they want to preserve for posterity, and how and why they wish to do this. On the other hand, we are also interested in the reasons why the state or Church suddenly

16 Piotr Kwiatkowski, Pamięć zbiorowa społeczeństwa polskiego $w$ okresie transformacji. Warsaw: Scholar, 2008; Barbara Szacka, Czas przeszły, pamięć, mit. Warsaw: Wydawnictwo Naukowe Scholar, 2006. 
begins to take an interest in local history, rediscover it, and make it an important component of their historical policy.

In this book, we put forward the thesis that, despite the local communities we studied having access to many diverse memory frameworks typical of late modernity, they primarily function within religious memory frameworks that are highly characteristic of milieux de mémoire. It is religion that provides them with a tool for remembering and interpreting the past while also forming the basis for evaluating, accepting, or rejecting memory narratives originating from other social orders. We also show that the state turns to religious language and symbolism as well when commemorating the war. It does this to bolster its moral capital in the international arena and matters of domestic policy. Incorporating the war into the centuriesold history of Christianity effectively sacralizes its meaning as an important historical event. Wartime attitudes have taken on a moral dimension as they begin to be exploited in state historical policy ${ }^{17}$. This is very important because in late modernity, as Michał Łuczewski claims, there has been a weakening of "the hegemony of economic capital through the dynamic accumulation of moral capital"18. The Church, with its centuries-old tradition, is in effect legitimizing the version of events proposed by the state. This turn by the state toward the stories of the nation's past being proposed by the Church is, therefore, a consequence of the global social transformations occurring in late modernity, a time when the vision of unstoppable progress has been exhausted and is being replaced by various forms of returning to the past.

\section{The Local Community in Late Modernity}

The era of late modernity in which we live is characterized by a form of social self-reflexivity toward traditions and our past that is provoking increasingly radical social changes ${ }^{19}$. However, although all communities are subject to narratives of change, the situation is rather more complex with traditional communities. In fact, there is no clear consensus among scholars about how such communities think, or even what they actually consist of. Furthermore, ethnographic studies show that our knowledge of the life of local communities is very limited and more reflective of what anthropologists and ethnographers imagine it should

17 Michał Łuczewski, Kapitał moralny. Polityki historyczne w późnej nowoczesności. Kraków: Ośrodek Myśli Politycznej, 2017.

18 Łuczewski, Kapitał moralny, p. 97.

19 Anthony Giddens, The Consequences of Modernity. Cambridge: Polity Press, 1999, p. 38. 
consist of than an accurate representation of the experienced reality ${ }^{20}$. Existing descriptions of traditional or rural communities are dominated by the conviction that such communities are "steeped in the past"21, or, turning to Pierre Nora's terminology, it may be said that they are living in milieux de mémoire. A classic example of this stance is the description of Polish peasant culture created by Ryszard Tomicki, who claims that in peasant culture "the past does not so much sacralize the history of a community because it does not possess such a history as sacralize its ageless or timeless cultural present. Every element of culture, even if it was relatively new yet accepted by the group, was 'synchronized' with all the other elements of culture by referring it to the past [...] which simultaneously, by 'confirming' its value, made it an integral ingredient ex definitione of an unchanging world order" 22 . In an approach of this type, the past, conceived as a constant presence permeating every aspect of communal life, is granted a key role in the explanation of the form assumed by a given culture. Such a stance has been adopted by researchers of illiterate societies who have treated them as "peoples without a history", communities permanently living or immersed in the past, or communities in which the past is at once their present and past ${ }^{23}$. These researchers emphasize that stability, invariability, and a tendency to preserve group values grounded in a system of beliefs are of paramount importance to the traditional community ${ }^{24}$. Ethnographers highlight the religious roots of the belief systems they describe in the Polish countryside. Such religious beliefs have become ever more deeply ingrained in the Polish national identity as traditional local communities undergo processes of transformation ${ }^{25}$.

In the local communities we studied, past time is concrete and has a place on a timeline that is distinct from what is happening today. In their own narratives,

20 Magdalena Lubańska, "Problemy etnograficznych badań nad religijnością." In: Religijność Chrześcijan obrządku Wschodniego na pograniczu polsko-ukraińskim, ed. Magdalena Lubańska. Warsaw: Wydawnictwo DIG, 2007, pp. 7-31.

21 Claude Lévi-Strauss and Georges Charbonnier. Conversations with Claude Lévi-Strauss. London: Cape, 1973.

22 Ryszard Tomicki, "Kultura-Dziedzictwo-Tradycja.” In: Etnografia Polski: przemiany kultury ludowej, Vol. 2, ed. Maria Biernacka et al. (Wrocław: Ossolineum, 1981), p. 362.

23 Harry Elmer Barnes, and Howard Becker. Social Thought from Lore to Science. New York: Dover Publications, 1961; Jacques Le Goff, History and Memory. New York: Columbia University Press, 1996.

24 Nora, "Between Memory and History"; Jerzy Szacki, Tradycja. Warsaw: WUW, 2011; Jan Vansina, Oral Tradition as History. Madison: University of Wisconsin Press, 1985.

25 Michał Łuczewski, Odwieczny naród. Polak i katolik w Żmiącej. Toruń: Wydawnictwo Naukowe UMK, 2012. 
people separate "wartime" from the continuum of social life and the dates appearing on the vernacular commemorative signs they construct serve as a continuous reminder of the passing of time. What really makes the manner in which these communities function stand out is their attitude toward the dead. At a local level, remembering the dead is more than a personal need. It is also a social and religious duty applicable to the whole community. There is an unquestioned belief among the community that deceased persons should be buried, then remembered in prayers, religious rituals and by tending to their places of burial. However, the fact that people from any given community fell victim to enemy action around the same time and were buried in collective graves also means that they will be remembered collectively. The same applies to religious rituals commemorating their deaths since these often comprise services that gather together the whole local community. Such evocations of religious language integrate past events into another reality in which the victims of these past events and those living today become one community. The duty to remember the dead is religious in nature and commemorative practices and the transmission of narratives of the past acquire a moral dimension. This is particularly evident in the case of memory of Second World War victims because the war lives on as a component of the community's memory. Witnesses to these events continue to live in the villages where they happened, passing on their personal stories to younger generations and tending to sites of memory. The institution assisting them as they perform these duties is the Catholic Church.

\section{The Second World War as a Key Event in Poland's Most Recent History}

Jay Winter ${ }^{26}$ points out that the two world wars were of crucial importance since they were the most convulsive events of the twentieth century. In Poland's case, both wars exerted a crucial influence on its current territorial and demographic state as well as its outlook on the world. In 1918, the First World War and geopolitical transformations in Europe led to Poland reappearing on the map of Europe as a sovereign state after a period of partition. This was a country mainly comprising lands that had historically belonged to the First Polish Republic, which existed from 1569 to $1795^{27}$. In the second half of the eighteenth century, these territories

26 Jay Winter, Remembering War: The Great War between Memory and History in the Twentieth Century, New Haven: Yale University Press, 2006.

27 On history of the First Polish Republic see Norman Davis, God's Playground: A History of Poland, Vol. 1: The Origins to 1795. New York: Columbia University Press, 1982. 
were incorporated into the Prussian, Austro-Hungarian, and Russian Empires, respectively, following the partitioning of Poland among these powers. This division of territory lasted until the end of the First World War ${ }^{28}$. The newly established Second Polish Republic was a multiethnic state, extremely diverse economically and assailed by continual political problems. Despite attempts at reform, ethnic conflicts became increasingly evident and nationalist and anti-Semitic attitudes came to the fore, which were given additional impetus by radicalizing sentiments visible throughout Europe. This politically and socially divided, economically weak country was then faced with the outbreak of the Second World War ${ }^{29}$.

On 1 September 1939, the armies of the Third Reich advanced into Polish territory from the west and north without declaring war. A few days later, on 17 September, under the provisions of the Ribbentrop-Molotov Pact, which had been signed by the Third Reich and Union of Soviet Socialist Republics (USSR) on 23 August 1939 and contained a secret protocol providing for the division of the states of Central and Eastern Europe between the two signatories, the Second Republic's eastern territories were occupied by the USSR ${ }^{30}$. The line dividing Poland between the Third Reich and USSR, which ran along the River Bug, was demarcated according to a Treaty on Borders and Friendship signed between the two powers on 28 September 1939 and remained in force until the armies of the Third Reich's surprise attack on the USSR on 22 June 1941. On the lands incorporated into the USSR, the Soviet system of administration was introduced, collectivization was implemented and repressions commenced. People from the uppermost social classes, representatives of the intelligentsia, employees of Polish state structures and all the uniformed services (from soldiers to policemen and foresters), the clergy, and wealthiest peasants were deported deep into the USSR, incarcerated in Narodny Komissariat Vnutrennikh Del (NKVD) prisons or killed.

The territories occupied by the Third Reich were divided up, with the lands in the west being directly incorporated into the German state and the remainder being transformed into the so-called General Government, with Kraków as its capital city. The position of governor was held by Hans Frank throughout the Government's existence. After the Third Reich attacked the Soviet territory in Galicia (the southeastern part of the Second Republic), the District of Galicia was created, which was then incorporated into the General Government, while

28 Norman Davis, God's Playground: A History of Poland, Vol. 2: 1795 to the Present Revised 2nd Edition. York: Columbia University Press, 2005.

29 Davis, God's Playground.

30 Timothy Snyder, Bloodlands: Europe Between Hitler and Stalin. New York: Basic Books, 2010. 
the rest of the land seized from the retreating Soviet army was divided into two Reichskommissariate. The region around the city of Białystok was also divided off to create a separate unit known as Bezirk Bialystok.

The German occupiers employed numerous methods of repression inhabitants of the occupied territories were sent deep into Germany to work, a system of food rationing was established, higher education establishments and numerous cultural and research institutions were closed down, representatives of the Polish intelligentsia were liquidated, there were mass executions on the streets, and villages were pacified; any attempt at resistance was punishable by death. The Jewish population was subjected to a policy aimed at their exploitation, repression, and, ultimately, extermination. Jews were deprived of their property and resettled in ghettos (the one functioning in Warsaw being the largest in Europe), where they died in enormous numbers from starvation and illness, as well as being deported to concentration camps. In 1942, Operation Reinhardt was launched, during which around two million Jews were sent to death or concentration camps and murdered. It was also in this year that the death penalty for hiding Jews was introduced in the General Government. In total, around three million Jews who had been Polish citizens before the war lost their lives during the war.

Throughout the war, the structures of the Polish state functioned as the government-in-exile, first based in France and later in London, and the Polish Underground State, which operated in occupied Poland. Resistance was organized on two levels, as an armed struggle and a civilian unit managed by the Directorate of Civil Resistance, which was formed in 1941. The underground armed forces, known as the Union of Armed Struggle, were formed in November 1939 and later transformed into the Home Army, ${ }^{31}$ which numbered about 380,000 soldiers. The underground organizations reflected political divisions from before the war. Besides the Home Army, there were a number of other military organizations, including the Peasant Battalions, which were created in 1940 by the peasant movement, the National Armed Forces, created in 1942 by the national camp (which continued an underground struggle with the Red Army and forces of communist Poland after the war) and the Gwardia Ludowa (People's Guard), created in 1942 by the Polish Workers' Party (which merged in 1944 with the Home Army, by then

31 The Home Army (AK) was the biggest Polish military resistance organization during the Second World War, active both on the territories occupied by Nazi Germany and the Soviet Union. It was subordinated to the Polish Underground State. For the history of the Home Army and the resistance movement in Poland, see Alexandra Richie, Warsaw 1944: Hitler, Himmler, and the Warsaw Uprising. New York: Farrar, Straus and Giroux, 2013, pp. 141-188. 
fighting alongside the Red Army). The largest of these organizations was the Home Army, which conducted about 730,000 operations over the course of the war ${ }^{32}$. The Polish government-in-exile responded to Operation Reinhardt and the commencement of the liquidation of the Warsaw ghetto by establishing the Council to Aid Jews (operating under the pseudonym of Żegota) in occupied Poland, which attempted to assist people living in and hiding outside the ghettos ${ }^{33}$.

The territories contained within the eastern part of the newly established Poland were liberated in 1944, and the first state structures dependent on the Soviet Union were created. The decision that over half of Poland's pre-war territory would not be included within the borders redrawn after the war was taken at the end of 1943 at the Tehran Conference. Furthermore, at the beginning of 1945, it was finally established at the Yalta Conference that Poland would be located within the Soviet zone of influence, receiving land taken from the German state as compensation for its lost eastern territories. Poland, therefore, emerged from the war and the double wartime occupation as a completely different state ${ }^{34}$.

The Second World War had altered Poland's borders, political system, and social structure. The Polish state lost almost half of its pre-war territory to the Soviet Union. The lost territories had been the most ethnically and religiously diverse part of the country. Moreover, over $90 \%$ of Poland's Jewish population had been lost to the Holocaust. The Polish state had been transformed from a multi-ethnic country in which national and ethnic minorities had made up $30 \%$ of the population to a state that was almost uniform in terms of nationality (today, no more than $4 \%$ of the population is made up of ethnic minorities). This also meant that the country was much less religiously diverse, with representatives of religions and denominations other than Roman Catholicism constituting only a fraction of Polish society after the war.

Profound social changes also occurred after the war. Not only did Poland find itself within the Soviet zone of influence, but a new socialist political system was introduced to the country ${ }^{35}$. Nationalization and agricultural reform led

32 Andrzej Friszke, Polska. Losy państwa i narodu 1939-1989. Warsaw: Iskry, 2003; Andrzej Paczkowski, Pół wieku dziejów Polski. Warsaw: Wydawnictwo Naukowe PWN, 2005.

33 Andrzej Krzysztof Kunert and Andrzej Friszke, “Żegota”. Rada Pomocy Żydom 19421945. Wybór dokumentów. Warsaw: ROPWiM, 2002.

34 Anna Wylegała, "Krajobraz po wojnie: anatomia rozpadu świata społecznego na przykładzie Polski w okresie II wojny światowej.” Studia Socjologiczne, No. 3, 2016, pp. 133-163.

35 Norman Davis, Heart of Europe: The Past in Poland's Present. Oxford: Oxford University Press, 2001. 
to the noble and gentry classes not only losing their position in the state and society but also their landed estates. According to the official state ideology, it was the working and peasant classes that were to receive most support from state institutions. In Poland, unlike other countries in the socialist bloc, no attempt was made to collectivize agriculture. Although state-owned farms were created on the Soviet model, collectivization was not the dominant mode of organizing agricultural production. Private ownership of farms was retained, but land was taken away from the landed gentry and wealthiest peasants and given to poorer inhabitants of the countryside. The countryside was gradually modernized, but the traditional way of life - which was based on family ties and associated with the institution of the Church and religious practices - lost none of its importance ${ }^{36}$.

Some scholars researching the effect of the war and post-war sociopolitical transformations on the life of villages and small towns stress that the social situation after the war markedly changed over time, as such phenomena as the "traditional village community" became a thing of the past ${ }^{37}$. Others emphasize that although a social revolution was taking place in post-war Poland, Polish society barely noticed this so failed to consider what effect it might have on the contemporary social situation in their country ${ }^{38}$.

Sociological studies emphasize the potent position the war occupies in Polish social memory: "Memory of the Second World War is living history, a source of family traditions and the focus of discussions with those who witnessed it. According to $72 \%$ of respondents to a $\mathrm{CBOS}^{39}$ survey conducted in 2009, the Second World War is, for them, 'a part of Polish history that continues to live on

36 Andrzej Paczkowski, Pół wieku dziejów Polski. Warsaw: Wydawnictwo Naukowe PWN, 2005.

37 According to Joanna Zalewska, the disappearance of the traditional community was primarily an outcome of transformations in daily life provoked by the transition of Polish society from custom to fashion. This transformation was brought about by the consumer revolution that took place in the Polish People's Republic after the war. See Joanna Zalewska, "Consumer revolution in People's Poland: Technologies in everyday life and the negotiation between custom and fashion (1945-1980)." Journal of Consumer Culture, Vol. 17, No. 2, 2017, pp. 321-339; Joanna Zalewska, Człowiek stary wobec zmiany kulturowej. Warsaw: Wydawnictwo Scholar, 2015.

38 Andrzej Leder, Prześniona rewolucja. Ćwiczenia $z$ logiki historycznej. Warsaw: Wydawnictwo Krytyki Politycznej, 2013.

39 The CBOS (Centre for Public Opinion Research) is a Warsaw-based opinion-polling institute. 
and of which we should be continually reminded" "40. A distinguishing feature of Polish memory of the war is the conviction that immediate family members were participating in events and processes of immense importance to the history of the whole nation, and as many as $86 \%$ of Poles point out that members of their closest family took part in it ${ }^{41}$. The war resonates very strongly with Poles and wrongs suffered by their compatriots during the war are perceived as wrongs suffered by people immensely close to them, whether family or acquaintances. As far as Polish remembrance policy is concerned (whether it is expressed through public discourse or transmitted by the education system), the war is primarily interpreted by means of two interlinked narratives, one, heroic, and the other, martyrological ${ }^{42}$. The events that are of key importance to the Polish memory discourse are the Warsaw Uprising of $1944,{ }^{43}$ the Katyn Massacre, ${ }^{44}$ and the establishment of Auschwitz ${ }^{45}$. Memory of the war has been incorporated

40 Lech M. Nijakowski, "Pamięć o II wojnie światowej a relacje Polaków z innymi narodami.” In: Między codziennością a wielką historią. Druga wojna światowa w pamięci zbiorowej społeczeństwa polskiego, eds. Piotr T. Kwiatkowski, Lech M. Nijakowski, Barbara Szacka, Andrzej Szpociński. Warsaw: Scholar, 2010, p. 241.

41 Piotr Kwiatkowski, Pamięć zbiorowa społeczeństwa polskiego w okresie transformacji. Warsaw: Scholar, 2008 p. 188-89; Piotr Kwiatkowski, "World War II as Collective Experience for Polish Society." In: World War II and Two Occupations. Dilemmas of Polish Memory, eds. Anna Wolff-Powęska, Piotr Forecki, Frankfurt am Main, Berlin, Bern, Bruxelles, New York, Oxford, Vienna: Peter Lang, 2016, pp. 13-38.

42 For an analysis of heroic and martyrological narratives in Polish culture that uses the example of historical museums, see Zuzanna Bogumił, Joanna Wawrzyniak, Tim Buchen, Christian Ganzer, and Maria Senina. The Enemy on Display. The Second World War in Eastern European Museums. Oxford and New York: Berghahn Books, 2015, p. 78-91, 95-97.

43 The Warsaw Uprising was an operation masterminded by the Polish resistance, in particular the Home Army. Its objective was to liberate Warsaw from German occupation. It started on 1 August 1944 and lasted for 63 days. See Włodzimierz Borodziej, The Warsaw Uprising of 1944. Madison: University of Wisconsin Press, 2006.

44 For the significance of Katyn for Polish contemporary culture and identity, see Aleksander Etkind, Rory Finnin, Uilleam Blacker, Julie Fedor, Simon Lewis, Maria Malksoo and Matilda Mroz, Remembering Katyn. Cambridge: Polity, 2012; Piotr Kosicki, "Forests, Families, and Films: Polish Memory of Katyń, 1943-2015." East European Politics and Societies and Cultures, Vol. 29, No. 4, 2015, pp. 730-760.

45 Geneviève Zubrzycki writes about the significance of Auschwitz for Catholic Poles. See Geneviève Zubrzycki, The Crosses of Auschwitz: Nationalism and Religion in PostCommunist Poland. Chicago: The University of Chicago Press, 2006. However, it should be stressed that in recent times Catholic Poles' perception of Auschwitz has changed, with the site increasingly being perceived as a "Jewish" site. See Marek Kucia Marta 
into a series of traumatic events ever present in Polish social memory, thereby becoming another instance of the Polish fate and often being viewed as the culmination of that fate.

\section{The Global Turn Toward Moral Narratives}

Remembrance policy and modes of commemoration are not suspended in a social vacuum - they need to react to the actions of other actors. Patterns of commemoration are continuously being influenced by new methods of transferring information (including multimediality and McDonaldization), a shift from the historical process toward an interest in biographies and the history of ordinary people and the referencing of global symbols within local contexts. Every reinterpretation of past events performed in one country provokes a response in others, and these responses can be particularly strong if such transformations of social interpretations are being applied to collective history ${ }^{46}$. As Conny Mithander, John Sundholm, and Arien Velicu pointed out while analyzing the memory situation in post-communist European countries, "Whereas in 1945 there was much that was in need of being forgotten, 1989 required a lot to be remembered. Thus, the 1990s witnessed the undertaking of several revisions of the post-war memory culture, both officially, due to state interventions and demands from the European Union, and locally, through initiatives by individual actions and minority groups" ${ }^{\prime 7}$. However, this explosion of memory work has prompted questions regarding what should be remembered, who has the right to call themselves a victim, how burgeoning memory conflicts should be resolved, and to what extent this can be achieved, if at all ${ }^{48}$.

The 1939-1945 war was a global conflict, so every action offering a reinterpretation of these events resonates around the world. This is particularly important in Europe, where the conflict began and the Holocaust took place - an event of

Duch-Dyngosz and Mateusz Magierowski, "The Collective Memory of Auschwitz and Second World War among Catholics in Poland: A Qualitative Study of Three Communities." History and Memory, Vol. 25, No. 2, 2013, pp. 132-173.

46 Jeffrey K. Olick, "Genre Memories and Memory Genres: A Dialogical Analysis of May 8, 1945 Commemorations in the Federal Republic of Germany." American Sociological Review, Vol. 64, 1999, pp. 381-402.

47 Conny Mithander, John Sundholm and Arien Velicu (eds). European Cultural Memory Post-89. Amsterdam. New York: Rodopi, 2013, p. 14.

48 Richard S. Esbenshade, "Remembering to Forget: Memory, History, National Identity in Postwar East-Central Europe.” Representations, 49 (1995): 72-96. 
global import that is recognized throughout the world - but it is also important for reflections on European identity. Initially, only the Germans were forced by the Holocaust to construct memory on negative grounds, but this challenge later began to apply to other nations as well: "Every nation that strived for full membership in the family of Europe had to adjust its narratives about the Second World War into a moral story" ${ }^{\prime 9}$. As a result, memory of the Holocaust has become, as Jeffrey Olick expressed it, an "entry ticket" to the European community ${ }^{50}$.

The Polish sociologist Michał Łuczewski maintains, in an analysis of the transformations that occurred in postwar attitudes to the past, that in late modernity economic capital is decreasing in importance while moral capital is becoming increasingly significant. He writes that "The most important thing for modern states constructing a story of the past is to establish, create and forcefully project a story of their own that is moral, universal and widely applicable (...) The most important task for the creators of historical policy is to construct a vision of the past that provides the nation they represent with a high moral status" ${ }^{51}$. Inspired by Aleida Assmann, ${ }^{52}$ and Michael Walzer, ${ }^{53}$ Łuczewski stresses that the key task for states is to define their own group within dimensions delineated by two dichotomies: victims/ perpetrators and victors/ the defeated. It is, therefore, possible to aspire to assign a given group to one of four social positions: heroes, victorious victims (the heroic), defeated victims (the traumatized), or perpetrators ${ }^{54}$.

The highest moral status in the contemporary global memory and commemoration network is offered by the position of the victim because "victims arouse the strongest moral emotions in us" ${ }^{\prime 5}$. These transformations in attitudes to the past in Europe have led to a memory boom and the construction of various memory projects aiming to accumulate the moral capital of particular nations. However, Michał Łuczewski focuses in his book exclusively on state historical

49 Mithander, Sundholm and Velicu, European Cultural Memory Post-89, p. 15.

50 Jeffrey K. Olick, The Politics of Regret. On Collective Memory and Historical Responsibility. New York: Routledge, 2007.

51 Łuczewski, Kapitał moralny, p. 25.

52 Aleida Assmann, "1998 - między historią a pamięcią”, trans. Magdalena SaryuszWolska. In: Pamięć zbiorow i kulturowa; współczesna perspektywa niemiecka, ed. Magdalena Sarytusz-Wolska. Kraków: Universitas, 2009, pp. 162-170.

53 Michael Walzer, Spheres of Justice: A Defense of Pluralism and Equality. New York: Basic Books Publishers, 1983.

54 Łuczewski, Kapitał moralny, p. 26.

55 Łuczewski, Kapitał moralny, p. 28. 
policy and the memory games that states conduct amongst themselves using their status as victims, victors, and perpetrators, thereby bolstering their own moral capital. He does not, in fact, draw attention to the role played in this process by Churches and religious narratives.

A similar opinion about the global turn toward narratives focusing on victims and perpetrators has been reached by the Korean memory researcher Jie-Hyun Lim, who has described the transnational phenomenon of victimhood nationalism. Lim, in his survey of the memory of various national and ethnic groups in Europe and Asia competing for primacy over the scale of the wrongs that have been inflicted on them and the victimhood they have borne, shows that this struggle is a transnational phenomenon that aims to create a hierarchy of victims. Uncontroversial victims par excellence who simply died senseless deaths are less valued than victims of the "sacrificial" type who gave up their lives in the name of higher values ${ }^{56}$. However, like Łuczewski, he does not attach any importance in his analyses to the role played in this process of sacralizing and conferring meaning on victims by religion and ecclesiastical institutions.

Any failure to take into account the role played by Churches and religion in the construction of moral capital in contemporary historical policy greatly narrows the scope of any attempt to understand this phenomenon. Secular language is lacking in words, metaphors, or narrative construction tools that are able to adequately describe and explain the mass sacrifice of non-combatants or victims of mass persecutions, cleansings, or shootings. Such events cannot be reduced to the notion of a struggle "for the survival of the nation". While significant persons or heroes can be commemorated through the erection of monuments that contain no religious references (for example, they may simply portray the dedicatees or take the form of a memorial obelisk bearing an inscription), commemorating large-scale group trauma is more difficult. In the case of heroes, it is their lives and achievements that are being commemorated, while victims of mass killings are commemorated as precisely that, so it is their deaths that are the subject.

Surviving a mass execution or being a witness to mass killings is a traumatic experience. However, as Jeffrey Alexander and Elizabeth Butler Breese claim, collective trauma differs markedly from individual trauma. "Individual victims react to traumatic injury with repression and denial, gaining relief when these

56 Jie-Hyun Lim, "Victimhood Nationalism in Contested Memories: National Mourning and Global Accountability." In: Memory in a Global Age. Discourses, Practices and Trajectories, eds. Aleida Assmann and Sebastian Conrad. Houndmills: Palgrave Macmillan, 2010, pp. 138-162. 
psychological defenses are overcome, bringing pain into consciousness so they are able to mourn. For collectivities, it is different. Rather than denial, repression, and working through, it is a matter of symbolic construction and framing, of creating a narrative and moving along from there" ${ }^{57}$. Alexander and Butler Breese develop their idea, arguing that "we must be constructed via narrative and coding, and it is this collective identity that experiences and confronts the danger" ${ }^{\prime 5}$. This is why not every example involving the massive suffering of individuals, even if this suffering is collective, leads to collective trauma. This can be analyzed on the example of the allied bombing of Germany that has not become a German collective trauma because "representations of the bombings never amounted to an authoritative representation orienting collective political and moral perceptions" 59 . In other words, there was no memory actor attempting to transform this mass experience into an identity-changing event. As a result, individuals suffered and may have experienced trauma, but this did not apply to the collectivity.

This is what makes a religion different. As Chris N. van der Merwe claims, "looking at trauma from the perspective of the loss of life-narratives puts the focus on the search for identity, meaning, and values. In the search for values, religion often plays an important role - not religion as a simplistic answer to all life's problems, but as a source of meaning"60. This power of religion to provide continuity and renewal for both individuals and the collectivity at times of trauma has been raised by both postcolonial and subaltern studies researchers, who have stressed that religion is capable of managing change both in personal life and within society. This is because religion offers a "representation of trauma". As Magdalena Lubańska writes, religious narratives "seek to find some added value in suffering; for instance, passion (in its etymological sense of suffering) can be viewed as a condition in which transcendence can manifest itself" ${ }^{\prime \prime}$.

57 Jeffrey C. Alexander and Elizabeth Butler Breese, "Introduction: On Social Suffering and Its Cultural Construction." In: Narrating Trauma: On the Impact of Collective Suffering, eds. Ronald Eyerman, Jeffrey C. Alexander and Elizabeth Butler Breese. New York: Routledge, 2011, p. XII-XIII.

58 Alexander and Breese, "Introduction", p. XIII.

59 Alexander and Breese, "Introduction", p. XIV.

60 Chris N. van der Merwe, "Rethinking Religion in a Time of Trauma." In: Trauma, Memory, and Narrative in the Contemporary South African Novel: Essays, eds. Ewald Mengel and Michela Borzaga. Amsderdam, New York: Rodopi, p. 196.

61 Lubańska, "Postmemory of Killings", p. 22. 
In the Christian religious imagination, which is one of our main concerns in this book, there is no such thing as meaningless suffering. All suffering can amount to martyrdom, and, as such, can have fundamental religious significance. If these victims were to be portrayed using secular imagery, they would become "meaningless victims" - a message that is hardly positive ${ }^{62}$. However, religions are able to construct positive narratives of this nature. If we consider European history, and such cultural constructs as, for instance, Moscow as a Third Rome, ${ }^{63}$ victimhood nationalism, ${ }^{64}$ and messianism, ${ }^{65}$ it becomes clear that historically, religion has always been able to deliver the social imaginary required for working through the traumatic past.

Modernity has also contributed to the development of forms of renewal associated with tradition ${ }^{66}$. As a consequence, when sacred rites return, they return in altered form. As Hervieu-Léger shows, that which is "religious" is more broadly defined in such a case. The new form which would appear to offer the strongest support for our argumentation is ethno-religion, which helps to rebuild the "we", a community destroyed by modernity. A rebuilding process of this nature implies the reorganization of forms of mobilization on the basis of symbols borrowed from historical religious traditions. Hervieu-Léger recalls the example of the "Polish-Catholic", a phenomenon that reached its fullest expression during Poland's Communist period. However, very similar phenomena are also present in other European countries. This opinion is shared by José Casanova, who claimed that "cultural matrices rooted in particular religious traditions and related institutional arrangements still serve to shape and encode, mostly unconsciously, diverse European secular practices" ${ }^{17}$.

62 Michał Bilewicz and Katarzyna Jabłońska, “Dobrze być ofiarą? - rozmowa.” Więź, Vol. 53, No. 2-3, 2010, p. 35

63 Peter Duncan, Russian Messianism. Third Rome, Revolution, Communism and After. London: Routledge, 2000.

64 Jie-Hyun Lim, "Victimhood Nationalism and History Reconciliation in East Asia." History Compass, Vol. 8(1), 2008, pp. 1-10.

65 Duncan, Russian Messianism; Andrzej Walicki, Filozofia polskiego romantyzmu. Kraków: Universitas, 2009.

66 Daniele Hervieu-Léger, Religion as a Chain of Memory. (Transl. from La religion pour mémoire by Simon Lee.). New Brunswick, New Jersey: Rutgers University Press, 2000.

67 José Casanova, “The Religious Situation in Europe.” In: Secularization and the World Religions, eds. Hans Joas and Klaus Wiegandt. Liverpool: Liverpool University Press, 2009, p. 228. 
Casanova and Hervieu-Léger show that this influence from religion is particularly evident in modern communities' attitude toward their past and assumes the form of the aforementioned constructs of Moscow as a Third Rome, victimhood nationalism or messianism. For many researchers, these concepts exemplify underdevelopment and a reluctance to confront the past. Others draw attention to the fact that "millions of people still live outside 'history. They do have theories of the past; they do believe that the past is important and shapes the present and the future, but they also recognize, confront, and live with a past different from that constructed by historians and historical consciousness. They even have a different way of arriving at that past" ${ }^{\prime \prime}$. We claim in this book that this phenomenon can readily be applied to the relationship some vernacular communities, for whom religion is the primary system of meanings and values, have with the past.

As Polish sociologist Jerzy Szacki stresses, there are two ways of looking at the past. Evidence in it can be sought for the persistence of the same virtues and sins, ideas, and values (of the present), or differences and disjunctures can be sought to the exclusion of anything else ${ }^{69}$. Memory research inspired by Aleida Assmann's conception of memory mostly concentrates on differences and disjunctures. However, to understand contemporary cultures of remembrance in Poland, it seems that explanations that seek the same virtues and sins in the past are much more useful. The events experienced in the twentieth century were so destructive and dislocating that there is a dramatic need in Poland to maintain a link with the past, and religion plays an enabling role in this.

\section{The Catholic Church and Religious Language Used for Commemorating the National Past}

From the end of the eighteenth century, when Poland disappeared from the map of Europe following the partitioning of its lands between Russia, Prussia, and Austria, the Catholic Church was able to strengthen its position as the most capacious repository of Polish culture, traditions, and collective memory because it was the only institution uniting Poles from different sectors of the partitioned country ${ }^{70}$. As a result of this development, religious symbols

68 Nandy Ashis, "History's Forgotten Doubles." History and Theory, Vol. 34, No. 2, 1995, p. 44.

69 Szacki, Tradycja, p. 237.

70 José Casanova, Public Religions in the Modern World. Chicago: Chicago University Press, 1994; José Casanova, Religion, European secular identities, and European integration. 2004. http:/www.bpb.de/system/files/pdf/XLKRLX.pdf (25 Feb. 2016). 
became important memory markers. The Catholic Church began to be perceived as a bastion of Polishness, and the concept of "Poland as the Christ of nations"71 completed the task of welding together religious and national elements. Poland's period of communism also played an important role in the strengthening of this relationship between nation and religion because it led to a situation where "Polish Catholicism historically has served more as a public civil religion than a private religion of individual salvation"72. The Catholic religion also performed the role during this period of a reservoir of national values (defined as being very closely allied to Catholicism) and one of the most important forces of opposition to the communist regime. Catholicism also proposed its own, alternative language for commemorating the past, which was embedded in religious and national tradition. As Ozan Can explains, "The external symbols such as monumental statues and mnemonic objects have a considerable significance in creating the cultural memory for groups which do not have one, and it boils down to the fact that the externally constructed symbolic objects, statues, institutions (...) contribute to both formulating and preserving the memory"73.

\section{Postwar Forms of Remembrance - a Time of Crosses and Shrines}

The first sites of memory appearing in the cultural landscape shortly after the Second World War were of a religious nature. Most of them were crosses spontaneously erected by people returning to towns and villages who wished to preserve the memory of their loved ones in the traditional manner. Apparently, the first attempts at commemoration in such places as Auschwitz-Birkenau or Majdanek were bottom-up grassroots initiatives ${ }^{74}$. However, from the end of the 1940s, most of these sites, and especially those regarded as being of key

71 This is a concept developed during the partitions in the Polish Romantic literary canon by the poet Adam Mickiewicz. He accounted for the sufferings of the Polish nation by claiming they would lead to the salvation of other nations, i.e. to them gaining their independence. Poland's resurrection was meant to lead to other national groups gaining their own states as well.

72 Casanova, Public Religions, p. 113.

73 Can Ozan, "Religion and Cultural Memory: A Case Study of Roman Catholic Sacraments, Monumental Statues, and Iconography." Anthropology of Communication, 5 December 2017, Budapest Metropolitan University, manuscript.

74 Zofia Wóycicka, Arrested Mourning. Memory of Nazi Camps in Poland, 1944-1950. Frankfurt am Main: Peter Lang, 2013. 
importance to the construction of a communist vision of the Polish nation's wartime martyrdom, were monopolized by the state language of remembrance ${ }^{75}$. Overwhelmingly, these new state memory markers replaced traditional forms of remembrance. A good example of this is the manner in which Warsaw's space was restructured after the war. In 1948, the Warsaw authorities announced a competition calling for memory projects commemorating sites of combat and martyrdom within the capital. It was won by the Warsaw-based sculptor Karol Tchorek and from that time onwards, traditional forms of remembrance were replaced by bas-reliefs carved in grey sandstone centered around Maltese crosses bearing the inscription: "A site sanctified by the blood of Poles who fought for the freedom of the motherland". From the 1950s to the 1990s, plaques designed by Tchorek were erected in great numbers at sites of memory located in Warsaw and towns and villages in close proximity to the capital. Despite their standardized form and ideologized language, the plaques in Wola marked the places where the loved ones of those who had survived the wartime murders in this

75 In 1945 the Main Commission for the Investigation of Nazi Crimes was created to conduct investigations into crimes that had been committed by Germans in Poland. Changing political circumstances have led to the commission being renamed several times. Between 1945 and 1949 it was named the Main Commission for the Investigation of German Crimes in Poland. In 1949, after the creation of two separate German states, the Main Commission was renamed the Main Commission for the Investigation of Hitlerite Crimes. This name functioned until 1991, when the scope of the commission's investigations was extended to incorporate Stalinist crimes and it was accordingly renamed the Commission for the Investigation of Crimes against the Polish Nation. Finally, in 1999, this body was replaced by the Main Commission for the Prosecution of Crimes against the Polish Nation, which formed part of the Institute of National Remembrance (IPN), which had been created in 1998. As the official English name frequently used in the literature to describe the period between 1945 and 1999 is the Main Commission for the Investigation of Nazi Crimes, we also use this term when we refer to this period of the commission's functioning. Only when we refer to the time after 1999 do we use the term the Commission for Prosecution of Crimes against the Polish Nation, because this is in fact a new institution. For more information. see: Alina Skibińska. Guide to the Sources on the Holocaust in Occupied Poland (Translated, revised and updated edition of the original Polish Źródta do badań nad zagłada Żydów na okupowanych ziemiach polskich by Alina Skibińska, Warsaw, 2007) https://jri-poland.org/help/Sources-on-the-Holocaust-in-OccupiedPoland.pdf; Pamięć wiecznie żywa. 40 lat działalności Rady Ochrony Pomników Walki i Męczeństwa 1947-1987. Warsaw: Rada Ochrony Pomników Walki i Męczeństwa, 1988; Irena Grzesiuk-Olszewska, Polska rzeźba pomnikowa w latach 1945-1995. Warsaw: Wydawnictwo Neriton, 1995. 
district of Warsaw had died. These survivors treated them as a symbolic grave where they could come and pray. This process was aided by the cross engraved on the plaques.

At sites where the authorities believed that these markers posed no threat to the state ideology, traditional forms of remembrance have survived to this day. One such example is the votive crosses and shrines commemorating the wartime fate of specific vernacular communities. This spontaneous post-war erection on a massive scale of religious memory markers by local populations laid the foundations for an alternative manner of commemorating the war that differed from the methods previously favored by the state. Rather than proposing a new language of remembrance like the state-sponsored memory projects that had appeared after the war, these shrines and crosses were regarded as traditional repositories of Polish memory. Many of these shrines constructed after the war can still be found in Poland today. Most of them have blended into the Polish rural cultural landscape and are viewed, along with other roadside crosses and shrines, as adding local color and an element of folklore rather than markers providing information about historical events, even though they usually contain an inscription making it clear what occasion they were erected to mark ${ }^{76}$. These sites are still generally well-maintained today, as is clear from the burning candles and fresh flowers that have been placed by them. Evidently, they serve as a focus of social life, though most of those praying at these sites tend to be older people.

The Polish People's Republic period was dominated by ideologized state memorial projects. The authorities constructed memorial complexes that were artistic in form and ideological in content at such sites as Majdanek, Westerplatte, and Auschwitz in order to commemorate events that were meant to shape the identity of any citizen of the People's Republic ${ }^{77}$. These projects commemorated in secular fashion heroes who had fallen in battle fighting for freedom. At the same time, they kept the fear of war alive and were meant to construct a national community based on vernacular communities' memory of their fate and pride at the final victory ${ }^{78}$.

76 Jan Adamowski and Marta Wójcicka (eds.), Krzyże i kapliczki przydrożne jako znaki społecznej, kulturowej i religijnej pamięci. Lublin: Wydawnictwo Uniwersytetu Marii Curie-Skłodowskiej, 2011.

77 Wóycicka, Arrested Mourning; Grzesiuk-Olszewska, Polska rzeźba pomnikowa.

78 Joanna Wawrzyniak, Veterans, Victims, and Memory. The Politics of the Second World War in Communist Poland. Translated by Simon Lewis. Frankfurt a.M.: Peter Lang, 2015. For the politics of memory of the Polish People's Republic, see Bartosz Korzeniewski, "World War II in the Politics of Memory of the Polish People's Republic 
In 1947, a state organization known as the Council for the Protection of Struggle and Martyrdom Sites was established that was tasked with creating sites of memory, maintaining them, and supervising the ideological and esthetic coherence of any new projects that were being created ${ }^{79}$. However, it was not only sites of memory regarded as symbols of the terror under occupation (such as the grounds of former concentration camps, prisons, battle sites) that were subject to state-sponsored remembrance practices, for, over time, vernacular sites of memory came under the influence of the state as they were incorporated into a national network of such sites by virtue of them being located on the newly created Martyrology of the Polish Nation Trails. Citizens participating in excursions along martyrological trails were able to discover the scale of the suffering that had been experienced, find out facts and information, and contribute to the construction of the community of fate the authorities wished to create ${ }^{80}$. The towns

1944-1970." In: World War II and Two Occupations. Dilemmas of Polish Memory, eds. Anna Wolff-Powęska, Piotr Forecki, Frankfurt am Main, Berlin, Bern, Bruxelles, New York, Oxford, Vienna: Peter Lang, 2016, pp. 61-80.

79 Pamięć wiecznie żywa.

80 In 1964, on the 25th anniversary of the outbreak of the Second World War, the Council for the Protection of Struggle and Martyrdom Sites published the first Guide to Sites Commemorating the Struggle and Martyrdom from the War Years 1939-1945, which contained ca. 2,000 entries providing information about sites "at which the Nazis committed their greatest crimes". The guide's goal, acknowledged at the time, was to educate Poland's youth by acquainting them with the actions that were "most important, commendable, and magnanimous in our history. At the same time, we want our youth to learn about the ideals in whose name the best sons of our nation died, so they may assimilate them and erect permanent memorials in their hearts to the fallen heroes". Around 20,000 sites were considered as potential entries for the next edition, but only some of them were chosen, those "that are particularly important due to the historical events [taking place] at that time". Consequently, as the authors of this edition explained, "we only marked those sites on it where NO LESS THAN 50 POLES died. (...) This is precisely how the truth about the years of the nation's struggle and the years of Nazi occupation in Poland presents itself". It was stressed in the preface to the third edition, published in 1980, that its authors' main objective was to continue "the process of educating society on the basis of historical facts while pointing out the role - in the struggle for freedom and human dignity - played by our nation's most progressive social forces". It was made clear in the preface to the fourth edition, published in 1988, that that edition covered "nearly all the memorial sites connected with the history of the Second World War and Nazi occupation in Poland. Thank to this special design, the 'Guide' is able to document the 40 years of activity of the Council for the Protection of Struggle and Martyrdom Sites, which (...) has led to those fighting for the freedom and independence of the Motherland 
of Jedwabne and Michniów, which are described in this book, were located on routes taken by such martyrological trails.

During the same period, an alternative system of sites of memory dedicated to those whom the communist authorities did not want to commemorate, in particular Home Army soldiers, Warsaw Uprising insurgents, and victims of the massacres at Katyn and in Volhynia, was created in church and cemetery grounds. The shrines, epitaphs, and commemorative plaques appearing in churches and cemeteries could not reveal the whole truth, give the names of organizations, or indicate exact sites, so they had to commemorate those the state was reluctant to commemorate by using religious symbols to incorporate them into a community comprising their dead ancestors. These places were perceived to be expressing the truth about the past and frequently became spaces for spontaneous protests against the authorities ${ }^{81}$. As a result, the commemorated freedom fighters also became champions of genuine remembrance of the past expressed using legitimate symbols. This was particularly evident during the Carnival of Solidarity ${ }^{82}$.

\section{Forms of Remembrance of the 1980s and 1990s - a Time of Sanctuaries}

The signing of the Gdańsk Agreement not only led to the legalization of the Solidarity Independent Self-Governing Labor Union, partial recovery of civil liberties, freedom of speech, the right of assembly, and restrictions on censorship, but also the commemoration of a past the communist authorities had tabooed.

and also the victims of the Nazi terror being honored in fitting fashion". Przewodnik po upamiętnionych miejscach walk i męczeństwa: lata wojny 1939-1945, eds. Czesław Czubryt-Borkowski and Jerzy Michasiewicz. Warsaw: Wydawnictwo "Sport i Turystyka", 1980; Przewodnik po upamiętnionych miejscach walk i męczeństwa: lata wojny 1939-1945, ed. Czesław Czubryt-Borkowski, Zygmunt Czarnocki [et al.]. Warsaw: Wydawnictwo "Sport i Turystyka", 1988.

81 See Aleksandra Jarosz, “Zbrodnia katyńska. Niespójna pamięć w kontekście miejsc pamięci o Katyniu na terenie Warszawy." In: Stare i nowe tendencje w obszarze pamięci społecznej, eds. Zuzanna Bogumił and Andrzej Szpociński. Warsaw: Scholar, 2018, pp. 145-176; Małgorzata Głowacka-Grajper, "Pamięć jako kapitał społeczności lokalnej. Narracje o Bitwie Warszawskiej 1920 roku w Radzyminie." In: Stare i nowe tendencje w obszarze pamięci społecznej, eds. Zuzanna Bogumił and Andrzej Szpociński. Warsaw: Scholar, 2018, pp. 318-352.

82 A term used to describe the period between August 1980 and 13 December 1981. This period saw the partial granting of civil liberties and restriction of communist censorship. 
Memorials taking the form of crosses and commemorative plaques containing cross symbols appeared in many places in Poland, becoming a distinct iconic element of the Solidarity movement's language of remembrance. The most significant example of this kind of commemoration is a memorial dedicated to the shipyard workers killed during the strikes of December 1970. It assumes the form of three monumental crosses. The memorial was unveiled in December 1980.

The imposition of martial law in December 1981 signaled the end of freedom and opportunities to legally commemorate the past ${ }^{83}$. The return of the repressions led to people appealing again to the Catholic Church to express the truth about the past. During this period, such places as St Stanislaus Kostka Church, where Solidarity's chaplain Father Jerzy Popiełuszko gave his "Masses for the Homeland", grew to the status of a symbol. After he was murdered by the security forces, the church changed into a sanctuary dedicated to Popiełuszko's memory, and his grave became a frequently visited site of memory ${ }^{84}$. Throughout Poland, other sanctuaries also appeared that attempted to comprehensively express the history of the martyrology of the Polish nation by combining modern history with the past. Examples of these include the Sanctuary of the Martyred Polish Brothers in Bydgoszcz, the Sanctuary to the Fallen and Murdered in the East at St Boromeusz Church in the Warsaw district of Powązki, and Our Holy Cross Lady of Sorrows Sanctuary in Kałków, which we write about in this book.

The increasing importance of Polish religious symbolism has caused the first conflicts over the symbolism of remembrance. The most prominent dispute was over the construction of a Carmelite convent and erection of crosses in a gravel yard in Auschwitz. This provoked a period of fierce conflict over Polish-Jewish memory that lasted for the whole of the 1990s and reached its culmination in the Jedwabne debate that took place at the beginning of the twenty-first century. This dispute was primarily concerned with how the past should be interpreted, but also considered the language of remembrance and who and what should be commemorated using which symbols. The dispute over the crosses in the gravel yard strengthened an existing conviction among Catholic conservative circles that it was in fact religious symbols that should be used to describe the Polish nation's fate ${ }^{85}$.

83 Gregory Domber, Empowering Revolution: America, Poland, and the End of the Cold War (The New Cold War History). Chapel Hill: The University of North Carolina Press, 2014.

84 Zygmunt Malacki Grzegorz Pfeifer and Ewa Anna Zając, Muzeum Sługi Bożego Ks. Jerzego Popiełuszki. Warsaw: Wydawnictwo Sióstr Loretanek, 2005.

85 Zubrzycki, The Crosses of Auschwitz. 
After the change of political system in 1989, the state slowly began constructing memorials to events that had earlier been tabooed ${ }^{86}$. The memorials created during this period commemorated specific groups of victims. However, no single central state monument or museum was created that commemorated all the war's victims. Such comprehensive visions of the fate of the nation only found their expression at the sanctuaries mentioned above.

Moreover, after the 1993 elections, some former communists returned to power who were not interested in commemorating the past and seeking a new language of remembrance ${ }^{87}$. Consequently, the main onus for the remembrance process in free Poland's first decade fell on army veteran circles and the families of victims. They were aided by Catholic priests who, faced with a lack of interest from the state, had become involved in commemorating those whose memory was yet to be commemorated in fitting fashion. This process found its expression in such actions as the placing of epitaphs and commemorative plaques in churches and the construction of memorials to Katyn, or Golgothas of the East, which were fervently advocated by the Chaplain of Katyn Families, the prelate Zdzisław Peszkowski. Furthermore, stained glass windows containing patriotic and religious scenes were installed in both freshly constructed and old reconstructed churches. If these are examined from close quarters, it can be seen that they represent a comprehensive vision of the past that superbly expresses the martyrology of the Polish nation ${ }^{88}$. Such memorials created on the initiative

86 Memorials of this kind unveiled in Warsaw included the Monument to the Heroes of the Warsaw Uprising unveiled in 1989, the Monument to Martyrs of the Communist Terror 1944-1956 unveiled in 1995, and the Monument to the Fallen and Murdered in the East. See Wojciech Ziembiński, "Pomnik Ofiar Agresji Sowieckiej 17 IX 1939." In: Warszawa o czym mówia pomniki i kamienie, eds. Karol Mórawski and Andrzej Stwarza. Warsaw: Muzeum Niepodległości, 2000, pp. 260-263; Irena GrzesiukOlszewska, "Pomniki stolicy ostatniego dziesięciolecia." In: Warszawa o czym mówiq pomniki i kamienie, eds. Karol Mórawski, Andrzej. Warsaw: Muzeum Niepodległości, 2000, pp. 276-284. In 1997, a monument was unveiled in Białystok known as the Tomb of the Unknown Siberian Deportee, which was transformed the next year into the Sanctuary of Siberian Deportees. See: Znaki Pamięci Polskiej Golgoty Wschodu województwa podlaskiego. Białystok: Buniak-Druk, 2015.

87 Tomasz Rawski, "Nieudana korekta? Post-komunistyczna polityka pamięci w polskim parlamencie (1989-2014)". A paper delivered to the G74 group at the 16th Sociology Convention, 14-17 September 2016, the University of Gdańsk.

88 A good example is provided by the stained-glass windows in the Church of St James the Apostle on Narutowicz Square in Warsaw. These were funded in 1988 by the September 1939 Soldiers, and veterans of the Home Army, and domestic and overseas Polish 
of victims supported by Catholic priests have appeared in many cities, towns, and villages in Poland, thereby becoming an integral component of the cultural landscape.

Even though discussions were already ongoing during this period on the need to create museums telling of the wartime fate of Poles that would also offer new interpretations of significant events, ${ }^{89}$ such institutions were not being created in the 1990s. Nevertheless, Halls of Memory were appearing, such as the one devoted to Siberian deportees at the Church of the Holy Spirit in Białystok ${ }^{90}$ or the first Katyn Museum, which was created by the Federation of Katyn Families and operates as a branch of the Polish Army Museum in Warsaw ${ }^{91}$. However, rather than serving as history museums with archives, these halls contained exhibitions of family memorabilia and resembled Germany's Heimat museums. Repressed persons or the close relatives of victims brought such memorabilia to the halls, which were then put on display according to their own feelings rather than museological-exhibiting principles. These places primarily served the close relatives of victims as a space for working through their past rather than as a space for general state education. It was they who guided visitors around these personal museums and the visitors they were showing around tended to

Armed Forces to mark the seventieth anniversary of the regaining of independence. The windows commemorate the struggle with "the hordes of the German occupier of Poland and Europe". Full of national and religious symbolism, Romantic literary quotes, and reconstructions of iconic symbols of particular historical events, they offer comprehensive narratives that are simple for a person raised within Polish culture to decode. This symbolic aspect was perfectly expressed by one of the people we interviewed, who, when asked about the symbolism of the windows, commented as follows: "These symbols are important. On the one hand, we see historical, and yes, patriotic elements, and on the other hand, there are religious elements. These are illustrated through such symbols as a tank and cross. It's clear what unites them. Bearing the cross was tiring and arduous, and the same applies to a tank going to war. I think that is how these symbols bear comparison. (...) Everything's connected. Everything boils down to one thing... to suffering. We've got the cross, we've got the tank, we've got the thorns. There are no smiling faces... every one of them is gloomy because war is terrible and evil. Everything relates to this suffering... to the Way of the Cross, which Jesus trod. All of this comes together as one. Could we even say a unified whole?"

89 Discussion about the establishment of the Warsaw Uprising Museum was taking place from the 1980s.

90 Znaki Pamięci Polskiej Golgoty.

91 Alina Siomkajło, Katyń w pomnikach świata. Warsaw: Agencja Wydawnicza CB, 2002, pp. $146-150$. 
be pilgrims rather than tourists. This state of affairs remained unchanged until the beginning of the twenty-first century, when important new memory actors emerged. The first of these was the state, which became interested in exploiting the past as a tool of historical policy and using history to bolster its moral capital. The other new memory actors mainly consisted of non-governmental organizations, associations, artists, and local government activists who perceived the past as an important element in the construction of a modern local community.

\section{Forms of Remembrance in the Twenty-First Century - a Time of Narrative Projects}

The beginnings of narrative remembrance in Poland are bound up with the foundation of the Warsaw Uprising Museum in 2004\%2. This first-of-its-kind modern, multimedial, and narrational institution of culture aroused enormous public interest and achieved political success, leading to other political circles becoming interested in replicating such success ${ }^{93}$. With the traditional monument and official state commemorations in a state of crisis, the potential of museums as new repositories of memory became apparent. During this period, existing museums were undergoing modernization and new institutions largely devoted, as it happens, to twentieth-century history were being created ${ }^{94}$.

It is worth adding that ecclesiastical circles were also beginning to turn to the language of the museum narrative during this period. In the same year as the Warsaw Uprising Museum was opened, the Blessed Father Jerzy Popiełuszko

92 Maria Kobielska, Polska kultura pamięci w XXI wieku: dominanty. Zbrodnia katyńska, powstanie warszawskie i stan wojenny. Warsaw: IBL Wydawnictwo, 2016; Monika Żychlińska, "Muzeum Powstania Warszawskiego jako wehikuł polskiej pamięci zbiorowej.” Kultura i Społeczeństwo, Vol. 53, No. 3, 2009, pp. 89-113.

93 Zuzanna Bogumił, "Miejsce pamięci versus symulacja przeszłości - druga wojna światowa na wystawach historycznych." Kultura i Społeczeństwo, Vol. LV, No. 4, 2011, pp. 149-170.

94 In 2007, a branch of the Historical Museum of the City of Kraków was opened at Oskar Schindler's Enamel Factory in Kraków, and this was followed by the opening of a number of other museums. Those which have been most widely discussed and aroused most public interest are the European Solidarity Center in Gdańsk (2014), the POLIN Museum of the History of Polish Jews in Warsaw (2014), the new Katyn Museum in Warsaw (2015), the Ulma Family Museum of Poles Saving Jews during Second World War Museum in Markowa (2016), and the Museum of the Second World War in Gdańsk (2017). Work is currently in progress on the Museum of the Martyrdom of Polish Villages in Michniów, the Museum of the Siberian Deportee in Białystok, and the Museum of Polish History in Warsaw. 
Museum was opened in the crypt of the St Stanisław Kostka Church in the Warsaw district of Żoliborz ${ }^{95}$. Subsequently, two more multimedia museums devoted to Father Jerzy Popiełuszko were opened, showing that museums were a form of remembrance that had now become typical of the Church as well as secular organizations ${ }^{96}$. Although these institutions have different missions and set themselves different goals, they employ the same exhibition techniques, which often reference the same historical sources and archival photographs. The line between the secular and sacred is becoming blurred, which cannot but influence the image of the past these places connote.

The aforementioned museums are drawing attention to another important dimension of the changes that are occurring, notably a clearly visible process in which institutions are turning to local histories and stories to highlight the exceptional nature of ordinary people's fates and explore the characteristics of the memory and identity situations at specific places. This interest in local history is manifesting itself in many different ways and serving various purposes. Some of the commemorative activities being undertaken do indeed merely aim to show the exceptional nature of a specific community's fate, isolating it, as it were, from national history. An excellent example of such activities are the attempts being made by non-profit organizations to incorporate memory of Jews into the memories of the Warsaw district of Muranów and city of Łódźp ${ }^{97}$. Such activities are also being undertaken by smaller associations in other regions of Poland.

Nevertheless, the remembrance system is becoming ever more centralized. The conservative Law and Justice party's three-year tenure in power from 2005

95 Karolina Obrębska, "Muzeum ks. Jerzego Popiełuszki w Warszawie jako miejsce kształtowania tożsamości społecznej poprzez doświadczenie religijne.” In: Stare i nowe tendencje w obszarze pamięci społecznej, eds. Zuzanna Bogumił and Andrzej Szpociński. Warsaw: Scholar, 2018, pp. 233-263; Zuzanna Bogumił, “The Blessed Jerzy Popiełuszko Museum in Warsaw: Between History and Religion." Cultures of History Forum. 12.01.2018. http://www.culture-of-history.uni-jena.de//exhibitions/poland/ the-blessed-jerzy-popieluszko-museum-in-warsaw-between-history-and-religion/ (16 Sept. 2018).

96 Another example is the Holy Father John Paul II Family Home Museum in Wadowice, which has been breaking attendance records.

97 Zuzanna Maciejczak, "Murale na warszawskim Muranowie jako nośniki pamięci miejsca." In: Stare $i$ nowe tendencje $w$ obszarze pamięci społecznej, eds. Zuzanna Bogumił and Andrzej Szpociński. Warsaw: Scholar, 2018, pp. 196-232; Joanna GubałaCzyżewska, "Upamiętnienie Holocaustu w Łodzi. Stare i nowe tendencje." In: Stare $i$ nowe tendencje $w$ obszarze pamięci społecznej, eds. Zuzanna Bogumił and Andrzej Szpociński. Warsaw: Scholar, 2018, pp. 77-109. 
to 2007 meant a return to the creation of official interpretations of the past and open conversations about the need for the state to develop its own historical policy. Furthermore, the state began to play the role of a guardian and propagator of the history of groups whose past was tabooed during the Polish People's Republic. These groups' tradition of remembrance based on the use of national and religious symbols was continued in the hope that if the state remained true to this language, it would be able to count on these groups' support. At the same time, the state consistently pursued its own historical policy, which led to the Parliament of the Republic of Poland becoming increasingly active in the creation of commemorative resolutions (a trend that continued over the years that followed). From 2007 to 2015, the liberal Civic Platform party was in power and also began to pursue its own historical and museum policy, although this policy focused more on the international (European) dimension of memory of Poland's past. Under the Civic Platform governments' tenure, such museums as the POLIN Museum of the History of Polish Jews, European Solidarity Center and Second World War Museum were established. The last of these museums became the focus of controversy when Law and Justice returned to power in 2015 and accused it of not showing enough Polish history and focusing more on the suffering of civilians than the heroism of combatants. This served as a clear signal of a shift in historical policy in which the heroic-martyrological aspect would take center stage again. In 2016, the Council for the Protection of Struggle and Martyrdom Sites was disbanded. This institution created during the Polish People's Republic, which had been tasked with developing a new, secular language of remembrance, had been shaping the Polish memory landscape for years, approving the form that monuments took, passing judgment on the content of the inscriptions they contained and taking care to ensure that remembrance ceremonies correlated with each other. Following the change of political system in 1989, this institution had devoted increasing attention to the history of the earlier mentioned groups emerging from the shadows and appropriated their religious-national language of remembrance to create sites of memory, mainly in the East, commemorating the martyrology of the Polish nation. Despite this turn toward the religious language of remembrance, the Council was disbanded because it was still associated with the old system.

The Council's dissolution did not amount to the state liberating memory and giving its assent to the free expression of remembrance. The Council's role was assumed by the Institute of National Remembrance (IPN), an institution created in 1998, which is still primarily occupied with the gathering and management of documents issued by the security organs during communist times, the conduction of academic research and investigations into Nazi and communist crimes, 
and public education. The IPN has also become the central state organ for commemorating the past. As things stand, the IPN is not only the guardian of Polish history but also the manner in which it is commemorated ${ }^{98}$.

It is worth drawing attention to another significant post-1989 change, namely a change in focus applying to the subjects around which debates on the past are centered. Rather than focusing on the Polish-German or Polish-Russian past to which most monuments of the 1990s such as the Katyn Memorials or Golgothas of the East were dedicated, the most heated debates on television and the pages of the most prominent newspapers and opinion-forming dailies are centered around Poles' wartime relations with their neighbors, in particular relations between ethnic Poles and their Jewish compatriots and the Polish-Ukrainian conflict ${ }^{99}$. Consequently, although victims of the Third Reich and USSR are currently the primary focus of official memorials in Poland, the strongest emotions are being provoked by debates about the victims of conflicts with groups of neighbors who were citizens of the same Polish state before the war. The transformations taking place in Polish memory are inextricably linked to global remembrance narratives and are imbued with an undeniable moral dimension.

\section{Research Methodology}

Although this book was inspired by the findings of the ongoing Milieux de mémoire in Eastern Europe - the Polish Case Study project, the aims of that project are more wide-ranging than the findings we present here (see the Acknowledgements section). In this book, we have limited ourselves to explaining the manner in which vernacular communities commemorate the past by drawing on case studies of four such communities in Poland: Kałków-Godów, Michniów, Jedwabne, and Markowa. We also trace how those communities reacted as they came to realize that at particular points in time and for various reasons their local histories had gained such fame throughout Poland that they had been incorporated into the

98 In April 2016, the government enacted a law "on the prohibition of the propagation of communism or any other totalitarian system through the naming of buildings, structures and facilities for public use", which aimed to complete the process of decommunizing street names in Poland: https://ipn.gov.pl/pl/aktualnosci/polityka/ zmiany-nazw-ulic/37180,Zmiany-nazw-ulic.html (last accessed 23 July 2017).

99 Andrii Portnov, "Clash of Victimhoods: the Volhynia Massacre in Polish and Ukrainian memory" (16 November 2016). https://www.opendemocracy.net/od-russia/andriiportnov/clash-of-victimhood-1943-volhynian-massacre-in-polish-and-ukrainianculture. 
remembrance practices of actors operating on behalf of state institutions or the Church.

The book is based on empirical material collected in the field from 2014 to 2017. We visited each of the places we were analyzing at least twice during the course of our research. At each of the places we investigated, we conducted between ten and twenty in-depth interviews with local inhabitants and the main memory actors operating at the time in these localities, including museum staff, local authority representatives, teachers, clerics, creators of new forms of remembrance and local history enthusiasts (around 50 interviews in total). We also conducted observations of vernacular remembrance ceremonies and documented each site of memory photographically. However, we did not limit ourselves to field work. We also conducted preliminary research of various online and print publications relating to each of the places under study. Apart from this, we analyzed the websites of every relevant commune (an administrative unit in Poland) and local museum in the areas we studied as well as other materials relating to our research focus. Preliminary archival research was conducted, where applicable. The research methodology we applied could be described as a patchwork or bricolage methodology ${ }^{100}$. Such an approach is typical of work conducted within a grounded theory paradigm in which research is not subjected to the constraints of a single methodology in dogmatic fashion. Instead, methods and sources are continuously verified, enabling the phenomenon under investigation to be described as fully and accurately as possible. In the case of our project, it was more important that no research had been previously conducted on milieux de mémoire, a phenomenon yet to receive an unequivocal definition. This explains why it was so important to find methods that would allow us to capture and describe the motifs lying behind vernacular modes of remembrance while also assisting us in the creation of theoretical frameworks allowing us to explain the phenomenon under investigation.

The matter was further complicated by the conviction, widely shared among researchers, that religious forms of commemoration in Poland are an outcome of the influence exerted by the Polish national martyrology, a phenomenon described and researched in depth by many other researchers ${ }^{101}$. Our research

100 Marta Kurkowska-Budzan, Antykomunistyczne podziemie zbrojne na Białostocczyźnie: analiza współczesnej symbolizacji przeszłości. Kraków: Towarzystwo Wydawnicze "Historia Iagellonica", 2009.

101 Maria Janion, Do Europy - tak, ale z naszymi zmarkymi. Warsaw: Wydawnictwo Sic!, 2000; Zubrzycki, The Crosses of Auschwitz. 
was therefore treated as a further contribution to other research on a well-known phenomenon rather than a project without precedent. Nevertheless, we believe that reductionism of this nature limits and narrows the meaning and perception of religious commemorations. As our research progressed, we became increasingly convinced that, while it was clear that institutional or individual actors well-versed in the Polish martyrological literature were consciously and willingly supporting this conception of commemoration, the fact that rural inhabitants employ the cross as a form of remembrance is not provoked by a desire to become part of the Polish martyrological narrative. In this case, their use of the cross stems from a personal ethical, esthetic, and epistemological conviction of the correctness of precisely this form of remembrance. This explains why, as we demonstrate in this book using Michniów as an example, the martyrological memory project imposed by the state can arouse the opposition of local inhabitants. Even though this project makes use of religious symbols, it is perceived as being in opposition to vernacular memory. This is because vernacular memory perceives religious symbols, especially those erected at important places for the local community, in its own way and is ready to defend its "own" manner of perceiving them even if this is at the expense of the Polish martyrology being more fully expressed.

We chose the four places mentioned above (Kałków-Godów, Michniów, Jedwabne, and Markowa) because we wished to show as fully as possible how a local community reacts to the appearance of an external memory actor that uses the example of that community's local history to create a national Polish memory project on the community's land. These are all places whose fate was dramatically affected by the Second World War yet did not experience any significant population exchanges during the period after the war. At the same time, they are small in size and far away from larger population centers. On the other hand, each of the cases we have presented displays a different problem and shows a local community employing different strategies and ways of functioning.

\section{The Book's Structure}

Each of the chapters can be read separately or they can be read in pairs. The local communities of Kałków-Godów and Michniów experienced German pacifications during the war but display two different responses to the experiencing of these. Moreover, these examples show that the reaction of a local community to a top-down memory project varies depending on whether the project is to be created by the Church or state. By contrast, Jedwabne and Markowa are examples of the manner in which memory of wartime relations 
between ethnic Poles and Polish Jews (in particular the killing and rescuing of Jewish compatriots) can function within local communities.

Every chapter is similar in structure. We provide brief information about a village or small town and use the existing historical literature to reconstruct a wartime event that has influenced the identity of the place in question today. We then go on to present the history of post-war remembrance practices. We show, in turn, who erected memory projects dedicated to the place under study's wartime experience and when and why they did this. After describing vernacular remembrance strategies, we present the assumptions and meaning of a top-down state- or church-sponsored memorial that has appeared in the place under investigation. We also present the local community's response to that top-down project. In cases where such a process occurred, we reconstruct the process of negotiation that determined the form assumed by the main memorial. We also attempt to show what provoked the ensuing conflict within the remembrance sphere.

In the first chapter, which is devoted to Kałków-Godów, we show that vernacular experiencing of trauma does not always become an identity-building element for subsequent generations. Moreover, despite the fact that KałkówGodów's local history inspired the construction of a top-down memory project, both local and national histories are being told and commemorated within different social orders and in a separate manner. At the same time, this example shows the symbolic and cultural potency of a project created by the Catholic Church and the inherent weaknesses of the political policy being pursued by mainstream political parties.

We go on in the next chapter to analyze the example of Michniów, showing how a traumatic experience can become an identity-building element for a local community. At the same time, this example shows how attached a local community can become to forms of remembrance it has created itself as well as its opposition to attempts to destroy its own mode of remembrance and tendency to treat such attempts as a threat to its own identity.

In the third chapter, which is devoted to Jedwabne, we show that a crime committed by a local community cannot be forgotten and necessitates a collective effort to cope with the sense of guilt. Rather than possessing the characteristics of a reflexive working through of the past, vernacular strategies tend to be embedded in vernacular collective perceptions of reality. However, they enable the community to live with feelings of guilt. Any attempts by external actors to impose a mode of commemorating and interpreting the past on a community are perceived by the community in question as a threat to its group identity. This explains why the community attempts to resist such impositions with enormous determination. 
In the final chapter, which is devoted to Markowa, we show the process leading to the creation of heroes and saints. We pay attention to the potency of family memory and the significance of the determination family members display during the process of making memory of their forebears public knowledge. The family we examine in this chapter, the Ulmas, have achieved the status of both national heroes and servants of God, so we show how state historical policy and the canonization process have been influencing actions taken by the local community and how it views its past. 


\section{Kałków-Godów}

Perhaps we haven't visited that many sanctuaries in our lives, but we have been to a few. In our view, the one in Katków-Godów is one of the most surprising places we've managed to get to and one of the most unforgettable shrines.

Kasia and Maciej Marczewski

Kasia and Maciej Marczewski run the Ruszaj w Droge (Hit the Road) Foundation, which promotes travel around Poland. As well as appearing on the radio and television and organizing training sessions and presentations, they run their own travel blog, which is visited by thousands of people a month ${ }^{102}$. They are tourists rather than pilgrims. After reading information about the Our Holy Cross Lady of Sorrows Sanctuary in Kałków-Godów, ${ }^{103}$ they went to visit it in 2013. As they explain: "It was not so much, however, the description of this place that caught our attention as its large pyramidal architectural form, which intrigued Maciek so much that he insisted on viewing it close up". The Marczewskis are referring here to the enormous medieval-castle-shaped Golgotha of the Polish Nation (Fig. 1.1), which towers over the Sanctuary.

Their visit to the Sanctuary made a huge impression on the bloggers. As they explain: "Our Holy Cross Lady of Sorrows Sanctuary in Kałków-Godów is one of the most interesting and thought-provoking monuments to Polish history". Their vivid blog entry concludes by asking why no information about this place can be found in Polish guidebooks: "Maybe the theme is not 'touristy' enough or fails to match the profile of a commercial attraction?" Indeed, there is no point in searching for information about Kałków-Godów in any of the popular Polish guidebooks. This does not, however, mean that the place is unknown or unvisited. In fact, Kałków receives around 800,000 visitors a year, favorably comparing

102 Ruszaj w Droge, a blog by Kasia and Maciej Marczewski: https://www.ruszajwdroge. pl/p/o-nas.html (last accessed: 8 Feb. 2018).

103 Kałków and Godów, normally known as Kałków-Godów, are two villages in the gmina (or Commune) of Pawłów in Starachowice County in the Świętokrzyskie (lit. Holy Cross) Voivodeship founded as early as the Middle Ages. 


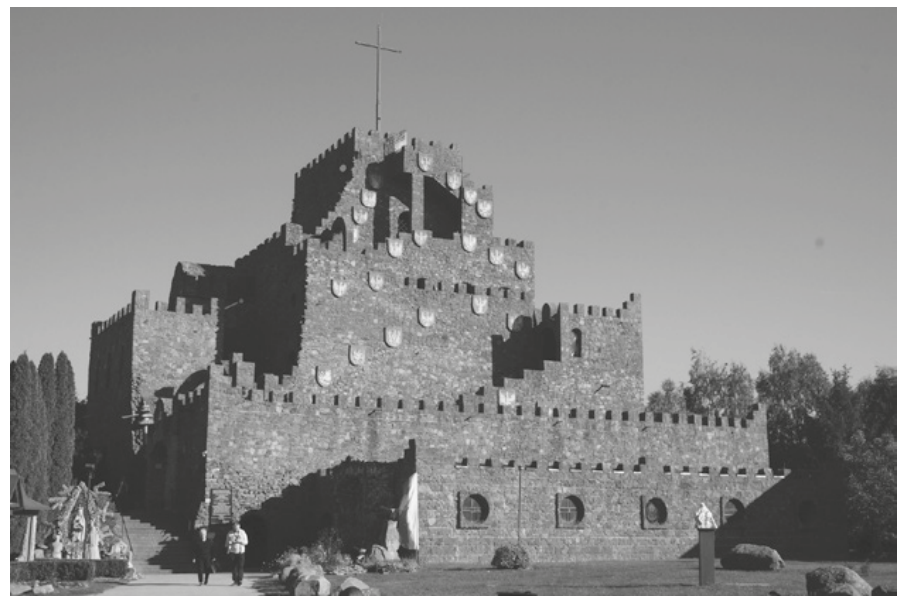

Fig. 1.1: The Golgotha of the Polish Nation in the Our Holy Cross Lady of Sorrows Sanctuary in Kałków-Godów. Photograph by Dariusz Bogumił.

with attendance figures at the Warsaw Uprising Museum, which is regarded as the most popular historical museum in Poland and Warsaw's top attraction, yet only attracts around 600,000 visitors (535,000 in $\left.2013^{104}\right)^{105}$. Everyone visiting Kałków climbs up to the Golgotha of the Polish Nation, which the Marczewskis' describe as an "extraordinary building", a patchwork of "chambers, cells and alcoves or larger cells, every one resembling a single painful event in Polish history. (...) These exhibition-memorials are laden with meaning. The saturation of descriptions, photographs and remembrances compel visitors to reflect. Even we - modern people, who would appear to have never felt the effects of war - had to bow down our heads and experience the sadness of the Polish nation's difficult history".

In their description of Kałków-Godów, the Marczewskis write nothing about the local history despite the fact that it is clear from other entries on their blog

104 “Muzeum Powstania Warszawskiego najciekawszym miejscem 2013.” Polskie Radio. 30 Dec. 2013. http://www.polskieradio.pl/5/3/Artykul/1013418,Muzeum-PowstaniaWarszawskiego-najciekawszym-miejscem-2013 (last accessed: 23 Mar. 2016).

105 During the millennial year of 2000, around a million pilgrims visited Kałków. See Stanisław Durlej and Janusz Gmitruk, Panteon chłopów polskich na ziemi świętokrzyskiej. Kielce-Warsaw: Ludowe Towarzystwo Naukowo-Kulturalne Oddział w Kielcach, Muzeum Historii Polskiego Ruchu Ludowego, 2008, p. 11. 
that they like to unearth and acquaint their readers with such history. This is all the more curious because this place's local history is inextricably interwoven with, or was even interrupted by, the Second World War - a war, according to the bloggers, which visitors cannot help but think about when they are there. Our interest in researching Kałków-Godów was primarily sparked by the lack of narrative continuity between the story of the past offered by the Sanctuary and the tragic events that occurred locally during the Second World War.

The description in this case study shows how, in a place where German troops carried out a pacification of the local population, a memory project arose that commemorates the trials of the entire Polish nation. We show how the local population remember the tragic events of 1943 and memorialize them by creating vernacular sites of memory. The local people are also being encouraged by their parish priest to become involved in the creation of a Sanctuary redolent of the suffering of Poland, or even that of the whole of humanity. The Sanctuary and Golgotha were created on the initiative of a priest of the Catholic Church, so our case study primarily focuses on how the local community are reacting to a religious meta-project commemorating the war and what kind of social and cultural role this project is fulfilling.

\section{Kałków-Godów During the Second World War}

During the Second World War, villages situated in the vicinity of the present day Kałków-Godów fell victim to the German policy of ensuring villagers bore collective responsibility for the actions of local partisans ${ }^{106}$. On 24 May and 11 November, divisions of the German military police carried out the pacification of the villages of Gębice and Żuchowiec ${ }^{107}$. These two operations led to the deaths of a probable combined total of 136 people, of whom most came from these

106 Tomasz Domański and Andrzej Jankowski, Represje niemieckie na wsi kieleckiej 19391945. Kielce: IPN, 2011.

107 This village's name is recorded variously in different documents and academic papers - sometimes as Żuchowiec, and at other times as Rzuchowiec. The "Rzuchowiec" variant appears in the Rejestr miejsc i faktów zbrodni popetnionych przez okupanta hitlerowskiego na ziemiach polskich $w$ latach 1939-1945. Województwo kieleckie. Warsaw: Ministerstwo Sprawiedliwości, Główna Komisja Badania Zbrodni Hitlerowskich w Polsce, 1980), and once in a paper titled Represje niemieckie na wsi kieleckiej 1939-1945, but the latter instance refers to another settlement near the town of Ostrowiec Świętokrzyski. However, the "Żuchowiec" variant is used more frequently. Moreover, this is how the name of this settlement has been recorded on every monument. 
two villages, though there were other victims from the villages of Doły Biskupie, Godów, and Krynki ${ }^{108}$.

The first pacification was carried out following an attack by an operation group of the Gwardia Ludowa from a nearby outpost in the commune of Kunów. Partisans from this group carried out a sabotage operation, cutting the telegraph cables along the Brody-Ilża and Styków-Gębice lines. In response, on the morning of 24 May 1943, Gębice was surrounded by a cordon. All the males over 14 years of age captured from Gębice, Żuchowiec, and nearby Doły Biskupie were led away from the village in a column and ushered to the shafts of an old metal ore mine. There they were shot with machine guns. Only one of them survived the execution by managing to escape. On the same day, the burning down of five houses led to the deaths of about 18 people, mostly women and children ${ }^{109}$.

The next pacification took place on 11 November 1943, when a small detachment of Germans appeared in Gębice. They were looking for the village leader. The soldiers came under machine gun fire from above, where the forester's lodge was located. A few hours later, the Germans responded to this firing incident by surrounding the villages of Żuchowiec and Gębice. All the inhabitants of both villages, irrespective of their age, were gathered together by the hunting lodge, which was first plundered and then torched. After nightfall, the detained villagers were taken behind the lodge and executed by firing squad. The only people to survive, when a few stray bullets missed their target, were two female residents of Żuchowiec. This November operation resulted in the deaths of 30 people ${ }^{110}$.

Those who survived the pacification had nothing to return to because whole villages were burnt to the ground. The resultant depopulation of these two settlements led to them being incorporated into the village of Godów after the war. Today, this village is known as Kałków-Godów, as the villages of Kałków and Godów are close enough to each other to have merged into a single line of buildings. Nevertheless, from an administrative point of view, they are regarded as separate units.

108 According to the findings of the 1968 session of the Kielce District Commission for the Investigation of Nazi Crimes in Poland, 23 inhabitants of Żuchowiec lost their lives, 54 from Gębice, 11 from Doły Biskupie, 7 from Godów, and 1 person from Krynki (Rejestr miejsc i faktów zbrodni, pp. 65-67).

109 Domański and Jankowski, Represje niemieckie, pp. 200-202.

110 Rejestr miejsc i faktów zbrodni, pp. 65-67. 


\section{Vernacular Memory of the Second World War}

The residents of Kałków-Godów remember the pacifications of the neighboring villages that the Germans carried out in 1943 . There are still people alive today who directly witnessed these events or were raised in an atmosphere in which they were continuously reminded of murdered family members and neighbors. The victims of the pacifications of 24 May 1943 from Żuchowiec, Gębice, and Doły Biskupie were initially buried by their relatives and neighbors in collective graves close to the burned villages. Later, their remains were exhumated and buried in the parish cemetery in Krynki, ${ }^{111}$ which is about 9 kilometers from Kałków-Godów. Nevertheless, the List of Sites of Martyrdom of the Holy Cross Voivodeship prepared in 1989 by Longin Kaczanowski and Bogusław Paprocki ${ }^{112}$ provides the information that the cemetery in Krynki contains "the grave of members of the Koniasz family murdered during the pacifications of the villages of Gębice and Żuchowiec, 24 May and 11 November 1943”, but nothing about a collective grave for all the murdered villagers in the cemetery. However, at the place of execution of the villagers in the wood one can also find another collective grave. The victims of the pacification of 11 November 1943 that were executed in the forest are buried there, "at the lodge", a site near to the place where they lost their lives. Today, this grave is surrounded by a wooden fence (Fig. 1.2), to which a plaque is affixed that reads: "The place of eternal rest of 28 people murdered by the Nazis at the lodge, 11.XI.1943, Honor their memory!”

Memory of the murdered victims was transmitted orally within families. Such methods of commemoration arise from the principles inherent in fulfilling both a religious obligation toward the deceased and the social obligation to preserve their memory. These are culturally sanctioned and have been practiced for many generations. According to statements made by the oldest people we interviewed, the pacifications and their victims were discussed almost constantly and remembering them was part and parcel of day-to-day life. There was not only a need to explain the absence of loved ones - including parents or siblings - to the

111 Up until the 1980s, Kałków and Godów belonged to the parish in the village of Krynki, which also contains the parish cemetery. Father Czesław Wala was the curate in this parish. Following the foundation of the new parish in Kałków-Godów, he became the parish priest.

112 Longin Kaczanowski and Bogusław Paprocki, Miejsca pamięci narodowej w województwie kieleckim 1939-1945. Biuro Dokumentacji Zabytków: Kielce, 1989. 


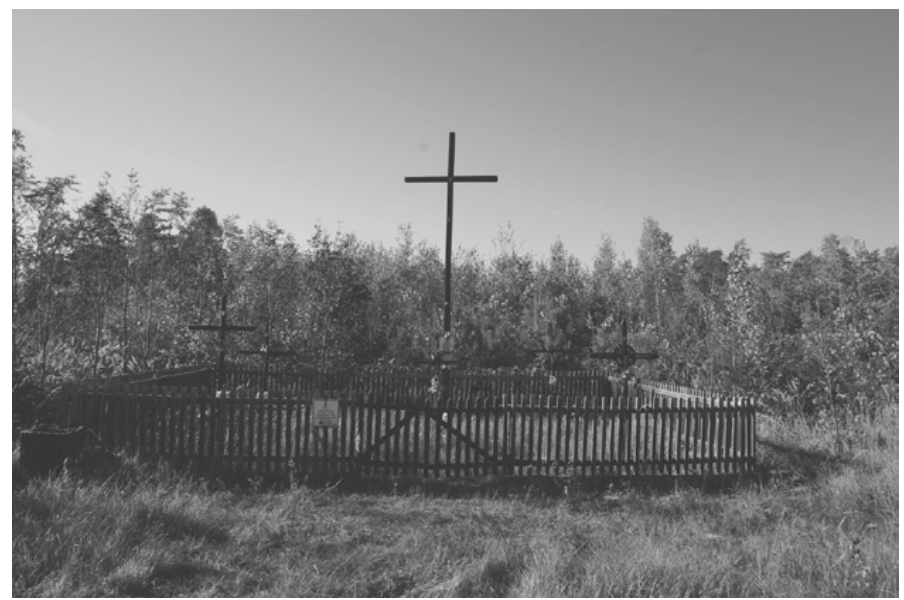

Fig. 1.2: The mass grave of the victims of the November 1943 pacification. The plaque contains the inscription: "The place of eternal rest of 28 people murdered by the Nazis at the lodge, 11.XI.1943, Honor their memory!” Photograph by Dariusz Bogumił.

generations that followed, but also to constantly revise a narrative relating the dichotomous division of the world into the evil - the German occupiers - and the good - the Poles, the villagers. This narrative was entirely consistent with the prevailing narratives promoted by the state after the war, ${ }^{113}$ which were socially transmitted through the education system, media broadcasts, and ceremonies organized by the local and central authorities.

In 1967, Father Czesław Wala was dispatched to the parish of Krynki. When he was still a curate, he attempted to increase levels of engagement with his parishioners, whom the local hierarchy perceived as a difficult target audience for pastoral work due to them not being very involved in the life of the Church. Czesław Ryszka describes an episode during this period of Father Wala's life when he had just arrived in Krynki parish and was accompanying his ministers on the local pilgrimage trail: "the road led through Żuchowiec, Kałków and Godów. He was not entirely sure which of these distant villages belonged to his new parish. He also did not know why the inhabitants of Żuchowiec took fright

113 Paweł Skibiński, Tomasz Wiścicki and Michał Wysocki, Polityka czy propaganda. PRL wobec historii. Warsaw: Muzeum Historii Polski, 2009. 
when they saw a priest. Only later, when he learned about their tragedy during the last war, did he understand their fear (...). This information was devastating for the young priest, arousing an even greater desire in him to serve the local residents" ${ }^{114}$. The local guide provides people visiting the Sanctuary with similar information. During our visit, she stressed that when Father Wala visited the villages lost between the forests, he noticed that "the lives of many more local inhabitants are dominated by memories of the war; those settlements of Gębice and Żuchowiec were burned to the ground, destroyed, their inhabitants were murdered" (F, ca. 35 years old, Kałków-Godów, November 2015).

Czesław Ryszka attributes the villagers' mistrust of the new priest to the fact that the Holy Cross Mountains were a theater of bloody battles between the partisans and Germans ${ }^{115}$. After the war, the secret political police captured former partisans and terrorized their families, explaining why the older villagers tried to live far away from the rest of the world and the Church, "believing that if they did this the communist authorities would forget about them"116. Having acquainted himself with these people's story, Father Wala, "immediately began to think about establishing a museum or hall of memory to pay homage to former Home Army soldiers", thus "dissolving [any obligations to] this patriotic bond and providing an outlet for a distinctive form of cult worship directed at elements of the past connected with the war"117.

In the 1970s, the Council for the Protection of Struggle and Martyrdom Sites erected national memorials at two sites associated with the pacification that took place in May 1943 (the first one close to the former village of Żuchowiec and the second one close to the former village of Gębice). The first monument (Fig. 1.3) bears the following inscription: "At this site on 24 May 1943 Nazis murdered 27 residents of the village of Żuchowiec. Honor to their Memory" and is signed by the "community of Iłża County May 1970"118. The central component of the national monument erected in 1970 that commemorates those residents of Żuchowiec who died in the May 1943 pacification is a granite stele. Today, this space is occupied by a statue of Our Lady, Queen of Poland, who

114 Czesław Ryszka, Sanktuarium pod Świętym Krzyżem: Kałków-Godów. Kraków-Radom: Wyd. Sióstr Loretanek, 2007, pp. 45-46.

115 Ryszka, Sanktuarium pod Świętym Krzyżem, p. 74.

116 Ryszka, Sanktuarium pod Świętym Krzyżem, p. 74.

117 Ryszka, Sanktuarium pod Świętym Krzyżem, p. 75.

118 All the described villages were in Iłża County, which existed until 1973. 


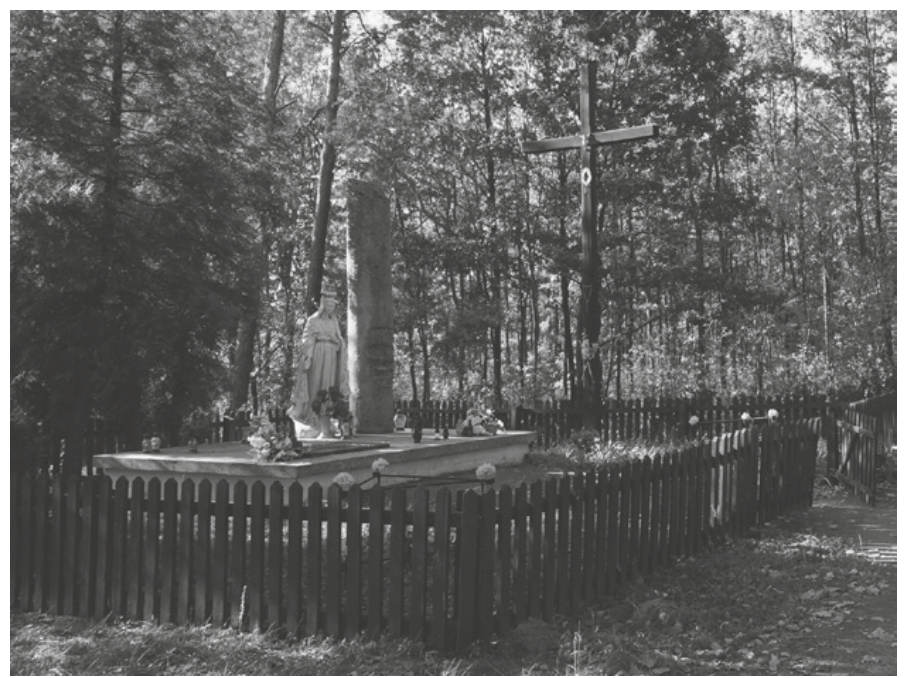

Fig. 1.3: The monument erected at the site of the mass pacification that took place in May 1943. The inscription provides the following information: "At this site on 24 May 1943 Nazis murdered 27 residents of the village of Żuchowiec. Hail to their Memory". The monument was erected in May 1970. Photograph by Dariusz Bogumił.

has a crowned eagle emblazoned on her chest. The second monument (Fig. 1.4) bears the following inscription: "A place sanctified by the martyrs' blood of 52 residents of the village of Gębice murdered by Nazis 24 May 1943. Honor to their Memory".

After the war, the villagers transferred the bodies of their loved ones from the pits dug in the forest (where the corpses were buried in 1943 and the monument erected in the 1970s stands today) to the parish cemetery in Krynki. One interviewee recalled that stories she heard from her family and neighbors indicated that everyone buried their loved ones in separate graves. Although these graves were next to each other, this was not regarded as a collective grave. The initiative to create an authentic collective grave and erect a single monument came from two female villagers who lost their fathers in the pacification. In the parish cemetery in Krynki, a collective grave was constructed in the 1980s, which was funded by donations from villagers (Fig. 1.5). Organizing a collective site of memory turned out for the locals to be a way of coping with their tragic memories. There is an inscription above a list containing the names of the victims, which reads: "They died that you might live" - a sentiment in keeping with both 


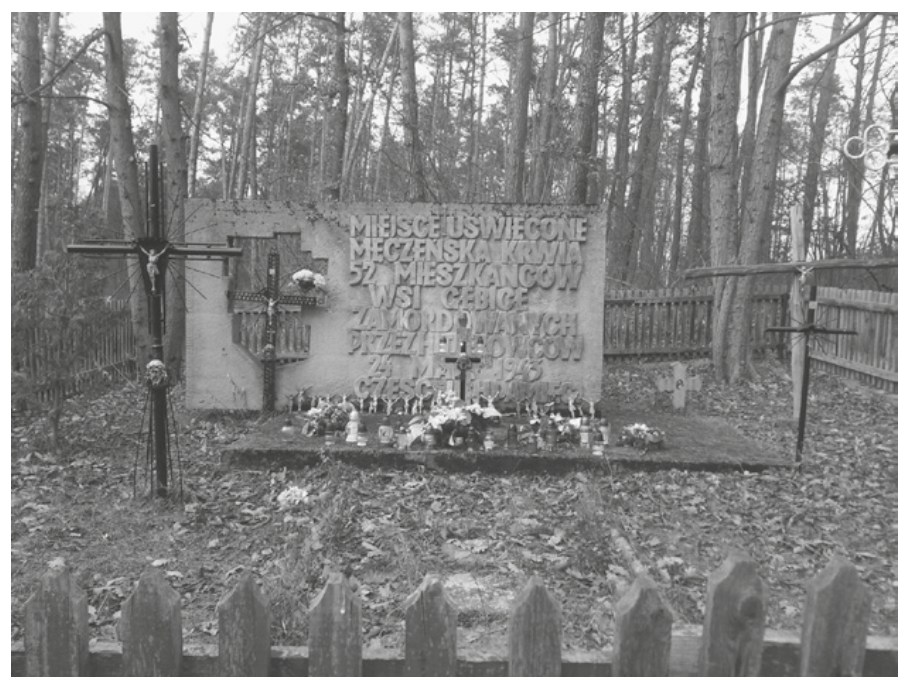

Fig. 1.4: The monument erected on site of the mass pacification that took place in May 1943. The inscription provides the following information: "A place sanctified by the martyrs' blood of 52 residents of the village of Gębice murdered by Nazis 24 May 1943. Honor to their Memory". Photograph by Marta Karkowska.

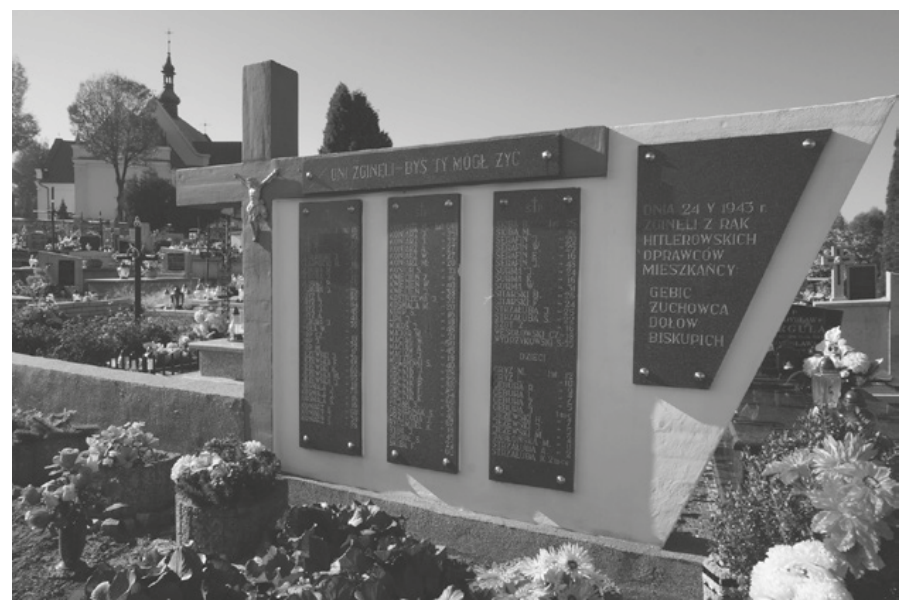

Fig. 1.5: The collective grave at the cemetery in Krynki, which was constructed in the 1980 s and funded by donations from villagers. Photograph by Dariusz Bogumił. 
the religious and national interpretations of the villagers' deaths. The bestiality of those who carried out the pacifications is emphasized by the inclusion of two lists on the monument, the first, a list of adult victims and the second, a list of murdered children, of which the youngest was only two months old. An inscription alongside these names reads: "On 24 V 1943 residents of Gębice, Żuchowiec and Doły Biskupie died at the hands of Nazi murderers". Over time, the Masses celebrated by this grave on the anniversaries of the pacifications have become a sacrosanct component of the local community's calendar, transforming them into a vernacular tradition. In 2016, the grave was renovated ${ }^{119}$.

After the new collective grave had been established at the cemetery in Krynki, people began taking the tiny metal crucifixes that had been affixed to the old wooden crosses erected at this cemetery to the site in the forest marking where their loved ones had been executed and standing them below the monument there (Fig. 1.4). As the interviewee mentioned above recalls, "these small crosses from individual graves were brought to the memorial, because people didn't want to profane them by throwing them away" (F, ca. 40 years old, Kałków-Godów, November 2015). Consequently, these objects of remembrance gained a second life as an element of the memorial that was constructed at a later date. However, the old memory markers were not removed for religious reasons - people could not imagine divesting themselves in any manner whatsoever of the crosses that had been standing on the victims' grave and commemorating specific people or families. Furthermore, even though the villages of Gębice and Żuchowiec had not functioned as separate entities since they had been destroyed during the war, memory of the murdered victims was inextricably linked to the names of the places from where they were killed. Despite the fact that two places no longer exist, those who were murdered are still known as the "victims from Żuchowiec" or the "victims from Gębice". These old place names are preserved over time in collective memory even if any connotations with today's administrative space have long since disappeared. People from both villages have been commemorated separately at the site where the tragic events took place, but they are jointly commemorated at the parish cemetery and on a plaque near the church in Kałków-Godów - places that are accessible to all inhabitants.

Every year, in May, a Holy Mass and remembrance ceremony for those who were murdered are held on the anniversary of the May pacification. The

119 “Zbiorowa mogiła w Krynkach odnowiona." 28 Oct. 2016. Echodnia.eu. http:// www.echodnia.eu/swietokrzyskie/wiadomosci/starachowice/a/zbiorowa-mogila-wkrynkach-odnowiona,10889349/. (last access: 9 Jan 2018). 
monument by the statue of Our Lady, Queen of Poland serves as focal point for this ceremony, which is organized by management and teachers from the nearby elementary school in Godów in cooperation with local government representatives and clergymen from the local Sanctuary. It comprises both artistic and religious elements. In 2017, the following was written about these events on a local information website ${ }^{120}$ : "As is the tradition, on the 74th anniversary of the pacification, the families of those who were murdered gathered together by the memorial to the victims with pupils from the Godów Elementary School looked after by Wanda Ciepielewska, the headteacher, firefighters from Kałków and the Wiarusy [lit. Old Comrades] Theater Group. The pupils presented a tailor-made program and the Wiarusy troupe performed a medley of melodies specially prepared for this ceremony. They received a standing ovation".

By contrast, the events of November 1943 are mentioned during church services organized to mark National Independence Day (11 November) that are held during the Holy Mass for the Motherland celebrated at the church at the Sanctuary in Kałków-Godów. While Father Wala was custos of the Sanctuary, the congregation used to walk in procession to the Pieta - a memorial alongside the entrance to the Sanctuary's church dedicated to those killed in action in the Holy Cross region (Fig. 1.6). This memorial was constructed on Father Wala's initiative in 1984 three years after the new parish's foundation (see below). One of the groups commemorated at this site with a separate plaque are the victims of both the pacified villages. The plaque, which is affixed to a stone, bears the following inscription: "In remembrance of the 104 Poles who fell in the pacification of the villages of Żuchowiec and Gębice 24 May and 11 November 1943. The living pay homage to them. 11 November $1984 " 121$.

It is worth stressing that neither the memorial-grave in the parish cemetery in Krynki nor the memorial in front of the Sanctuary (and maybe even the statue of the Our Lady, Queen of Poland near one of the national monuments dating from the 1970s) would have been created without Father Wala's assistance. The priest was not from one of the neighboring villages. He actually came

120 Kazimierz Cuch, "Uroczysta rocznica pacyfikacji Żuchowca i Gębic. Władze zlekceważyły wydarzenie." 29 May 2017. Echodnia.eu. http://www.echodnia. eu/swietokrzyskie/wiadomosci/starachowice/a/uroczysta-rocznica-pacyfikacjizuchowca-i-gebic-wladze-zlekcewazyli-wydarzenie,12124324/ (last accessed: 9 Jan. 2018).

121 Allusions to the pacifications can also be found in one of the images containing the text of a prayer to Mary, Mother of God at the bottom part of the Sanctuary's church. 


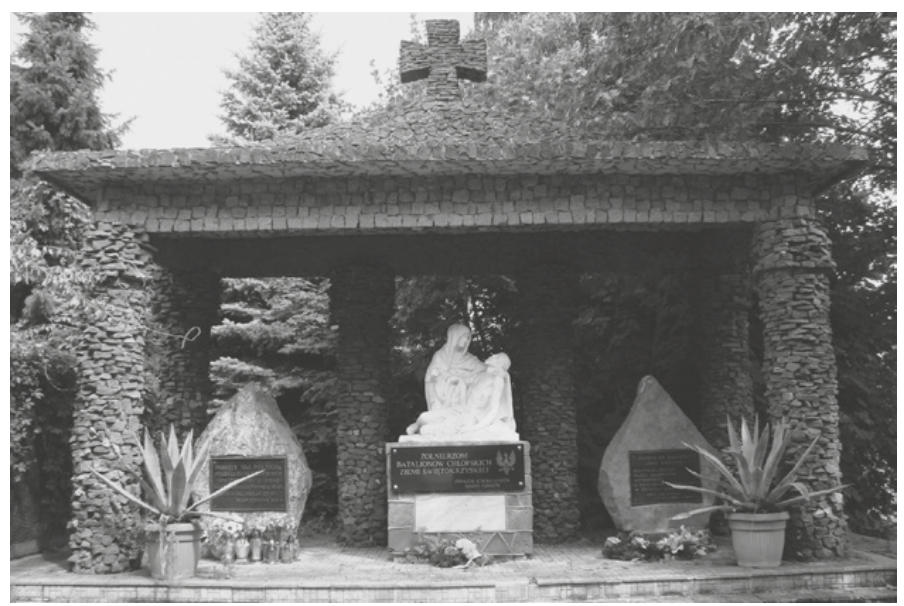

Fig. 1.6: Pieta - a memorial alongside the entrance to the Our Holy Cross Lady of Sorrows Sanctuary in Kałków-Godów dedicated to those killed in action in the Holy Cross region during the war, and the stone monument containing a plaque commemorating the victims of Żuchowiec and Gębice, the villages pacified in 1943. Photograph by Marta Karkowska.

from the town of Rudnik nad Sanem in the Subcarpathian Voivodeship and was dispatched to the parish of Krynki to complete pastoral work by his church superiors. Seeing that his parishioners were living in the shadow of a tragic wartime experience, he was very quick to become involved in memory work. Thanks to his efforts, the villagers acquired sites at which they could practice collective remembrance rituals. These practices transformed a collection of individuals who had lost loved ones into a community of victims. Their tragic story and the pain they experienced when remembering it were now officially acknowledged and recognized, thereby contributing to both a religious narrative (by means of the villagers' favored method of commemoration) and the prevailing national narrative (through them being clearly defined as Polish victims of German crimes).

The interviewees expressed differing opinions about the meaning of the wartime events and the role memory of these should play in relation to successive generations. For some of them, the memory of these events lives on by being efficiently transferred from generation to generation. It has its own rituals, the most important being the annual collection of money from local residents for the organization of the Mass for the murder victims on 
the anniversary of the pacifications. One of the interviewees was personally involved in the collection of this money for many years, but her role has now been taken over by two other, younger women who lost grandparents in the pacifications: "that's how it passes from generation to generation" (F, ca. 90 years old, Kałków-Godów, November 2015). In her view, schoolteachers also do their utmost to pass on local memory and get children involved in the remembrance ceremonies: "that's how it's been since the fifties, from school to school, from generation to generation, the teachers see to everything" (F, ca. 90 years old, Kałków-Godów, November 2015). However, other interviewees are not so optimistic, claiming that although the children and grandchildren of direct witnesses to the tragedy constantly hear stories about it at home, they are not actually interested in the past or in the remembrance activities. This was mentioned by one of the older interviewees: "Those whose family members were among the victims know to give for the Mass. But there are others who are young and won't even move their butts, they don't even go to the Mass" (F \& M, group interview, ca. 95 years old, Kałków-Godów, November 2015).

Some villagers are of the opinion that memory of the murder victims is increasingly limited to the victims' closest family members. An interviewee who works at the school claims that the priest announces when the ceremonies will take place in the press, and some of these are attended by people who have not lived in the area for a long time yet have preserved the memory of these events. Nevertheless, if the families and communities of the two villages affected by the pacification are discounted, there is little awareness of local past events. The leader of the local commune even claims that young people who do not live in these villages do not know anything about the pacification.

When he was interviewed, he also highlighted transformations linked to a nationwide reorientation of memory policy that had provoked changes in the educational system: "I don't think there's much [coverage], this subject rarely crops up in conversation and in the press. When I was still young, I remember those distant times, a lot of emphasis was placed [on it], once this Polish role in the Second World War was very prominent. This was probably also policy related, but a lot was said about the pacifications, less was said about the Katyn crimes, and more about the German pacifications" (M, ca. 40 years old, KałkówGodów, November 2015).

The change in memory policy after 1989 entailed a greater focus being placed on facts that had been concealed about Polish-Russian and Polish-Soviet relations and on the reconstruction of memory of events connected to these facts. Consequently, German war crimes were pushed into the background though not 
forgotten. Sometimes, the fact that less emphasis was placed on remembering these was justified by the prevailing raison d'etat - establishing the best possible relations with the Germans. In such an atmosphere, the organization of remembrance ceremonies was abandoned in the early 1990s, as one person from the local school recalls: "this was abandoned and at the end of the nineties, the ceremonies were resumed” (F, ca. 40 years old, Kałków-Godów, November 2015). However, their resumption was not provoked by the aspirations of local residents or a change in state memory policy, but rather by the fact that Józef Kwiecień, ${ }^{122}$ a man whose family had lost many of its members during the pacifications, became Marshall of the Holy Cross Voivodeship. He ensured the continuation of the ceremonies commemorating his family and the neighbors from his village by bringing about their official resumption. However, it is noteworthy that this break of almost 10 years had no effect on vernacular commemorations that were of a religious nature - the Masses for the murder victims were held every year during this period. The hiatus only applied at local government level. The authorities abandoned their involvement in the ceremonies and stopped organizing the secular part of them.

However, it turns out from statements made by people connected with the Sanctuary in Kałków-Godów that the issue of intergenerational transfer does not present a special challenge for them. In their view, evoking the suffering and passion of Christ or the traditions of Polish patriotism make the transferred message understandable enough to require no further explanation. Statements made by one of the priests reveal his conviction that the younger generations can become active recipients of the entire narrative: "The older people identify themselves [with the history], and the younger people, as [part of an] educational, patriotic education or upbringing, it's as if they learn this history from commemorative plaques, oratories, and such like" (M, ca. 50 years old, Kałków-Godów, November 2015). For the younger generations and people with no personal connection to the events presented in the Sanctuary's narrative, the most important factor should be its overall message, and this should reveal the connection between personal sacrifice and the fate of the nation as well as the close relationship between religion (both in the institutional sense and as a set of symbolic tools explaining reality) and national history.

122 Józef Kwiecień is a local politician. He was born in 1944 in Godów and from 2001 to 2002 was Marshall of the Holy Cross Voivodeship. 


\section{Local Controversies Connected with Memory of the Second World War}

While everyone regards the desire to commemorate the victims of the pacifications as clear and morally ambiguous, no consensus has been reached over the interpretation of the sequence of events that led to it. The leader of the commune, who does not come from either of the two villages affected by the tragedy, recalls how surprised he was by the atmosphere accompanying the procedure of naming a school in the nearby village of Rzepin after "Ponury" - the Home Army officer sent from Warsaw to command the local partisans during the war: "and the older people who remembered the time of guerrilla warfare did not remember this time well. (...) there were certainly not any such positive recollections, though we have an idealized image (...) almost every day, they encountered those problems, remembered that fear, while we remember the heroism of those partisans, we value it" (M, ca. 40 years old, Kałków-Godów, November 2015).

In the opinion of some of the local residents, it was the campaigns organized by Ponury that drew German reprisals upon villagers who had nothing to do with the partisans' operations. A third-generation local resident stressed that: "the partisans weren't from around here, but it was here that people were helping them" (F, ca. 40 years old, Kałków-Godów, November 2015). Referencing a story told her by her grandmother, she stated:

I believe they weren't aware enough of the issue of the struggle against the occupiers to become involved themselves. Yes, they lived their lives, but as grandmother recalled, sometimes partisans appeared and some bread had to be baked for them and at other times, it was Germans, and then Russians. As for the pacification that took place here, that was an act of retaliation for helping the partisans, but the locals didn't really understand that either. (...) and this wasn't a genuine attempt at cooperation, it was more like one person wishing to help another, and it ended in tragedy. (F, ca. 40 years old, KałkówGodów, November 2015)

The inhabitants of the pacified villages are therefore presented in these locally appearing interpretations as victims of a Grand History played out above their heads. The conflict between the German occupiers and the Polish resistance movements placed them in an impossible situation. Their only intention was to continue living their traditional, peaceful lives, but they were dragged into this conflict against their wills, even though, as can be concluded from the aforementioned interview comments, their awareness of what it meant to be Polish did not extend far beyond identifying themselves with a specific language and religion, let alone affiliation to an ideological national community. This not only means 
that they became victims of a Polish-German (defined in terms of national ideology) conflict during the war, but their subsequent memory of these events fell victim to an official unifying national narrative, which transformed partisans into national heroes fighting for Poland's independence ${ }^{123}$. As the leader of the commune states: "nobody would dare to protest more vocally, but in this environment such things were said" (M, ca. 40 years old, Kałków-Godów, November 2015). This is why the local community did not come out with an initiative to construct a monument or site of memory in their village, even though such sites were being established in other regions in the Holy Cross Mountains ${ }^{124}$. One of the most important of these is the Chapel of the Home Army Partisans in the grounds of the Sanctuary (see below), but this was built on Father Wala's initiative.

The villagers cherish the family memory they pass down from generation to generation. However, this memory is bound by religious constraints explaining that every instance of suffering, every death has some point in God's eyes, however unnecessary or senseless it may be in purely human terms. This is the interpretation they relate to most closely because it can be assimilated into their lives and manner of perceiving the world more seamlessly than the need to wage a struggle with an occupying force in the name of national liberation even at the cost of multiple human casualties. However, in their villages, the religious and national narratives are closely interlinked in numerous remembrances of twentieth-century events, including the vernacular ones found in the Sanctuary. However, the historical description presented at the Sanctuary makes no attempt to justify any need to incur casualties for the sake of the nation. On the contrary,

123 In the latter stages of the Second World War and after the war, many former soldiers of different military organizations became members of the anti-communist resistance in Poland (1944-1956). The communist propaganda called them "cursed" soldiers. They were also referred to as "doomed" or "damned" soldiers. In 2016, the Polish government established a memorial day to commemorate these partisans. This is called the "Indomitable Soldiers National Remembrance Day" and is celebrated on 1 March. For the Polish anti-Soviet resistance, see Chris Kostov, The Communist Century: From Revolution To Decay: 1917 to 2000. AUK Authors, 2015, p. 72; Tennent H. Bagley, Spy Wars: Moles, Mysteries, and Deadly Games. Yale: Yale University Press, 2007, pp. $120-130$.

124 In the Holy Cross Mountains region, there are many remembrances to be found of Ponury (e.g., his grave at Wykus, where his remains were transferred in 1988 from Navahrudak) and other partisans. Such remembrances can also be found in the grounds of the Sanctuary in Kałków-Godów. 
it throws light on national history by presenting the fixed notion of a need to sacrifice oneself in the name of common, primarily religious, values.

\section{National Martyrdom in the Sanctuary Narrative}

The parish established in Kałków-Godów in 1981 was the first community in Poland dedicated to St Maximilian Maria Kolbe - a Polish Second World War martyr murdered at Auschwitz, ${ }^{125}$ beatified in 1971, and canonized in 1982. Before the Sanctuary was founded, its future parish priest Father Czesław Wala had built a chapel in the village dedicated to the same saint. Initially, it served as a classroom used for instructing children in religion, but after some time church services and patriotic religious ceremonies began to be held in $i^{126}$. The introduction of martial law on 13 December 1981 provided the impetus to create the Our Holy Cross Lady of Sorrows Sanctuary ${ }^{127}$. On the initiative of Father Czesław Wala, founder of the Sanctuary and its custos for many years (1982-2012), night vigils for the Motherland commenced on the first Saturday after this key date of 13 December 1981. Father Wala recalled this event as follows: "As soon as this shameful decree was declared, we began penitential vigils for the Motherland. The motivation for this form of piety was born of the needs of the heart and [our] faith. Services were held every Saturday. With every passing week, an increasing number of people who prayed sincerely took part. We adopted Our Lady with the Eagle on her breast as a patron for our vigils, because She alone loves Polish hearts and will never forsake them"128.

The construction of the shrine commenced in April 1982, though the local authorities were very inimical to the initiative. In May, an image of the Blessed Virgin Mary with a crowned eagle on her breast was transferred there from the Sanctuary in Licheń, a very important place linking the Marian cult with national ideology (due to the veneration surrounding the image in Lichen of the Blessed Virgin Mary Listening Patiently and a miracle that occurred there in 1850 , during the Russian partition period $\left.{ }^{129}\right)$. Father Wala's parishioners and

125 Maximilian Maria Kolbe (1894-1941), a Polish Conventual Franciscan friar, missionary, martyr, and Catholic saint.

126 Czesław Ryszka, Kałków-Godów: Sanktuarium pod Świętym Krzyżem. Warsaw: Wydawnictwo Sióstr Loretanek, 2002.

127 Ryszka, Kałków-Godów.

128 Cited from website of Our Holy Cross Lady of Sorrows Sanctuary in Kałków-Godów http://www.kalkow.com.pl/Historia.php (last access: 23 July 2017).

129 For the history and contemporary significance of the image of the Sanctuary in Lichen, see Kinga Sekerdej, Agnieszka Pasieka and Marta Warat, "Popular Religion 
inhabitants of neighboring villages built the church with their own hands, completing the building in November 1983, after 153 days of labor.

On 10 June 1984, during Pentecost, the lower church was ceremoniously consecrated along with the chapel dedicated to Home Army partisans that is inside it. As Czesław Ryszka writes, "The patron of the partisans' chapel is Our Lady of Sorrows from Wykus, that is, from that forest clearing in the Holy Cross Mountains, on the road from Rataje to Bodzentyn, which Ponury called the Home Army's home"130. The chapel walls contain images whose content has been gleaned from the "Holy Cross Litany". The first solemn Mass for the Motherland was held there on 11 November 1984. As Ryszka has written, partisans from all over Poland came to this Mass to take part in the all-night "vigil for the Motherland"131. On the same day, the ceremonial consecration of the Pieta monument (Fig. 1.6), which commemorates local wartime history, took place. The central component of this memorial is the Pieta itself, namely a representation of Mary holding Jesus' body, under which there is a plaque bearing the inscription: "To the soldiers of the Peasant Battalions of the Holy Cross region. The Veterans Association of the commune of Pawłów". Alongside this inscription is a carving of a crowned eagle - a symbol of the nation. On the righthand side, there is a stone devoted to the AK (Home Army) soldiers executed by firing squad following battles in the village of Święta Katarzyna, about 30 kilometers from Kałków. To the left, there is a stone commemorating those who were murdered in the pacifications of the villages of Żuchowiec and Gębice on 24 May and November 1943. The victims of the pacification are therefore only one of the groups commemorated at this site and are certainly much less visible than the AK partisans to whom the chapel in the lower church was also dedicated.

Over time, Kałków increasingly began to assume the form of a site of memory commemorating the Polish nation's twentieth-century martyrology. The key year in this process was 1986, when the Golgotha of the Polish Nation ${ }^{132}$ was built in

and Postsocialist Nostalgia. Lichen as a Polysemic Pilgrimage Centre in Poland." The Polish Sociological Review, Vol. 4(160), 2007, pp. 431-444.

130 Ryszka, Sanktuarium pod Świętym Krzyżem, p. 102.

131 Ryszka, Sanktuarium pod Świętym Krzyżem, p. 103.

132 The incorporation of elements from Polish history into the religious narrative of the Savior's Passion and resurrection is not only a feature of the local imagination in the Holy Cross region. It is a nationwide phenomenon. Golgothas with a national dimension are being established in other places in Poland, e.g., Tylicz (in South-East Poland) contains the Golgotha of the Beskids; Bydgoszcz (the capital of a province north of Warsaw) contains the Golgotha of the 20th Century (known as the Bydgoszcz Calvary); Będzin (in South Poland) contains the Sanctuary of the Polish Golgotha of 
the Sanctuary's grounds (Fig. 1.1). The Golgotha resembles a castle with a cross. As Jan Pałyga wrote:

The thing about a castle is that it stands and defends land, people, values. And if it no longer has a defensive function, it bears witness to what was important for a particular region of people who lived and died here. It reminds posterity that there is no escaping history. That it is inscribed into the land and the people who live here. Man cannot detach himself from the roots and lifeblood he has drawn from the ground. That is why the building has this form rather than any other (...) For as the earth collects ashes, the castle bears witness to history ${ }^{133}$.

The building is 33 meters high and surmounted by a 15-meter-high oak Cross of Salvation, which is visible from far away (and illuminated by night). This cross testifies to the "cross's presence in the life of every person, in the life of the nation and the state"134. The building's façade is embellished with 22 Polish coats of arms from various eras. As one of the priests explains, the coats of arms gradually work their way up to the cross surmounting the building that is illuminated by night:

by which I mean our nation's path to victory through the cross. Such is the nature of the Golgotha in its entirety, by showing special personalities and historical events, the history of our nation, as it were, though this [approach] of course has its limitations, because there is no other way [of presenting this history], but all these oratories show great people, figures who have made their mark on the history of our nation, also without necessarily viewing things from a typically ecclesiastical perspective [but concluding instead] that this is a priest or bishop, but there are also [important] secular people. Every person who has come into being has become part of the history of the nation through their conduct, word, deeds or heroism. (M, ca. 50 years old, KałkówGodów, November 2015)

The five-story stone building houses 30 chapels and oratories commemorating historical figures and events regarded as crucial for comprehending the Polish nation's fate in the twentieth century. Their dedicatees include: Our Lady of Częstochowa ${ }^{135}$ and other important figures in the Polish church (including

the East; the Calvary Road of the Polish Nation (commemorating the deeds of Polish soldiers in 1920) has been built in Radzymin (a city near Warsaw, site of the Battle of Warsaw (1920), also known as the "Miracle on the Vistula"); Iwonicz-Zdrój (South Poland, in the Beskid Niski Mountains) contains the Golgotha of the Polish Nation.

133 Ryszka, Sanktuarium pod Świętym Krzyżem, p. 113.

134 Ryszka, Sanktuarium pod Świętym Krzyżem, p. 113.

135 Our Lady of Częstochowa, also known as the Black Madonna, is an icon of unknown authorship kept at a monastery in Jasna Góra that presents the Blessed Virgin Mary 
Cardinal Stefan Wyszyński, often referred to as Primate of the Millenium, Saint Zygmunt Szczęsny Feliński, the Blessed Jerzy Popiełuszko, and Saint Maximilian Maria Kolbe ${ }^{136}$ ), tragic events from twentieth-century Polish history (for example, the nine miners murdered in the Wujek Coal Mine, the shipyard workers that died on the Baltic coast in $1970^{137}$ ), and also orally and aurally challenged people from all over Poland. Space is also provided for national and regional activists of the Solidarity Independent Governing Trade Union, bus drivers, miners, railroad men and miners from all over Poland, members of the AK, NSZ, and $\mathrm{WiN}^{138}$ and also the Polish People's Party ${ }^{139}$. There are chapels dedicated to Poles murdered and incarcerated in the East, including the Polish officers murdered at Katyn. By the entrance to the Golgotha, there is an expansive exhibition devoted to Poles honored with the title of "Righteous among the Nations" for saving Jews during the Second World War, something which was - as chroniclers of local events have emphasized - immensely important to the Sanctuary's founder, Father Wala, whose ancestors came from a devout Jewish family ${ }^{140}$.

By the entrance to the Golgotha, there is a memorial to Smolensk that was erected to commemorate the catastrophic airplane crash there on 20 April 2010

with the Baby Jesus. This icon, regarded as miraculous, is treated with special veneration and is one of the most recognizable symbols of Christianity in Poland.

136 All these people are figures of importance to Polish history of the nineteenth and twentieth centuries and the Polish Catholic Church. They are regarded as symbols of steadfastness, the struggle over the right to assert Polish identity, and self-sacrifice for the good of one's faith and humanity.

137 These are the crimes committed by the communist system that are most frequently cited in contemporary public discourse to underline the oppressiveness of this system.

138 The National Armed Forces (NSZ), much like the Home Army (AK), was a military organization active during the Second World War. After the war, it was also known for its anti-communist activities. WiN is an acronym for a resistance movement known as "Freedom and Independence". This was a civilian military organization founded in 1945 in Warsaw whose role was to fight both politically and militarily against the communists.

139 The Polish People's Party (PSL) is the oldest and most powerful peasant party in Poland. It only attracts modest countrywide support (although enough for it to be represented in every parliament), but it is very influential in rural areas. It is in the Holy Cross Voivodeship that it enjoys its greatest support, and initiatives commemorating Second World War victims from a peasant background are often supported by this party's politicians.

140 Ryszka, Kałków-Godów. 
in which the President of the Republic of Poland and many representatives from the highest echelons of government lost their lives. Since this is a relatively recent event that still provokes political controversy in Poland, one of the priests clearly emphasized that this project has no links other than to the sphere of memory ${ }^{141}$ : "memory, not politics, don't confuse these two notions $(\ldots)$ this is just memory, there is no attempt to distinguish whether someone is a Catholic or a non-Catholic or Orthodox, it makes no difference. Whether someone is a believer or non-believer makes no difference. These are people we wish to remember" (M, ca. 50 years old, Kałków-Godów, November 2015).

The catastrophe afflicting the presidential plane was an event without precedent in Polish history and so tragic that the memorial's creators believed that it was very important to commemorate it at a site that combined a narrative of the suffering and deaths of individuals with the history of the nation. Moreover, everyone who died in the catastrophe was on their way to ceremonies commemorating another tragic event - the execution of Polish officers at Katyn on the orders of the Soviet authorities in $1940^{142}$. There is therefore an element of dying for the liberation of one's country in this episode even though this does not directly apply to the biographies of those on the plane to Smolensk.

As Czesław Ryszka has written: "When new chapels were being built year by year on the Golgotha, [chapels] dedicated to great and holy Poles and those Poles who have left a permanent mark on the history of our nation, everyone stopped questioning the sense of this building. Everyone was convinced that the latest Polish history had been recorded inside it, an extraordinary history encapsulated in paintings and events, a history of suffering, struggling and death, the history of the Polish soul"143. Further expansion of the Golgotha is not anticipated due to lack of space. The narrative of this Golgotha has been closed and completed. The most that could happen is more commemorative

141 The monument was criticized by Polish liberal press for its lack of esthetic values and its creators for their "parochialism". Such arguments are typical among the liberal press for criticizing pious local rural communities for their "backwardness" and ideological stance on national issues. In all likelihood, it is opinions such as these that made people connected with the Sanctuary ill-disposed toward any attempts to engage them in conversation, so it was only possible to conduct a few, quite perfunctory interviews with them. This situation had an impact on the research material we collected.

142 Etkind et al., Remembering Katyn.

143 Ryszka, Sanktuarium pod Świętym Krzyżem, p. 114. 
plaques could appear on the building's walls (M, ca. 50 years old, KałkówGodów, November 2015).

It is worth stressing that after the Golgotha was constructed, the stone containing the plaque commemorating the victims of the pacification of Gębice and Żuchowice was not brought into its space. The local tragedy is not commemorated within the bounds of the Golgotha in any manner whatsoever. As a local woman working at the Sanctuary explained: "but why duplicate these places? There's a monument here already, this is something even grander, everything concerning this site here is already special and distinct, this is near the church and this is something very important; there [on the Golgotha] there is the martyrology of the Polish nation, and [the stone] here is [dedicated] to those people, those two villages and those who were murdered from those two villages" (F, ca. 70 years old, Kałków-Godów, November 2015).

The local tragedy is therefore remembered outside the Golgotha, at sites that are important for, and resonate emotionally with, the villagers as well as being closely linked to the constancy of their daily religious practices. The first such site is the collective grave at the parish cemetery in Krynki. The second one is the aforementioned monument standing near the entrance to the church in the grounds of the Sanctuary in Kałków-Godów that serves as the villager's parish church.

According to the official interpretation presented on the Sanctuary's website: "The Golgotha was meant to commemorate the sacrifice of martyred Poles from ancient and modern times and to bear testimony to the fact that Poland has kept its faith in the Cross and the Gospel. Inside the Golgotha the latest Polish history has been recorded, (...). In this, Christ's Passion and the torments of the Polish nation merge into one"144. The history of twentieth-century Poland and the tragic events that accompanied it have therefore been granted an unequivocal interpretation. The victims of the Second World War and the communist era are being presented as contemporary martyrs - their example is shaping models of morality and their sacrifice demands to be commemorated and venerated. Their deaths must be granted the status of an ultimate sacrifice possessing eschatological overtones.

Although there are many oratories and remembrances of individuals on Golgotha, its general meaning relates to the whole Polish nation. The people that are referenced are not only illustrations and examples of this suffering, but also

144 Quotation from official website of the Sanctuary, http://www.kalkow.com.pl/view1. php?MMcat=g\&MMarg=0; (last accessed: 9 Jan. 2018). 
of fortitude in the face of an enemy that is the personification of evil. The key element linking the history of salvation and that of the nation is the concept of sacrifice. Both religious and national memory are of a martyrological nature, for they focus on the notion of paying the ultimate sacrifice and the consequences of this, which are defined in terms of other individuals and a community being granted a new life. The fundamental objective of both forms of memory is to preserve for future generations a narrative promoting sacrifice in the name of one's fellow man and the community.

The term martyrdom has therefore acquired a national dimension, yet still retains its universal application. The religious language applied to the remembrance of victims of war and the communist era provokes and nurtures strong emotions. Moreover, it facilitates the transmission of memory of these victims because tragic historical events are becoming part of the universal schema of the martyred victim who makes it possible for future generations to live. If such an interpretation is applied, memory becomes a social obligation and an important component of collective identity. The effectiveness of this form of transmission can be confirmed by citing another entry from Kasia and Maciej Marczewskis blog quoted at the beginning of this case study, in which they reflect on their trip as they climb the Golgotha: 'Astonishment, shock, pain and the question 'why?' But that's not all how could it be that our ancestors died for... a country. What was driving them to do that? Bravura? Courage? Or maybe... though it's scary to say this today - love for the Motherland?" When they reached the second floor, they wrote: "a sense of defiance and anger began to well up in us at what had been done to us, to Poles, at the injustices visited on our compatriots, at the suffering that Poland had been through, and that includes us - children of the third generation - though nowadays few people are aware of this".

The climax of the path through the Golgotha is the entrance to its summit, which affords a panorama of the surrounding area. A similar approach has been used there to the one employed at the new Yad Vashem museum, where viewers who have finished looking at the exhibition walk out to a terrace affording a view of Jerusalem to deeply reflect on what they have just encountered. However, there is a subtle difference between these two types of reflection. In the case of Yad Vashem, the view is meant to provoke reflection on Israeli statehood, while the panorama in Kałków urges viewers to reflect on the meaning of their own lives. Kasia and Maciej Marczewski express this phenomenon on their blog as follows:

And when we left the Sanctuary with heavy hearts, the repulsive and uncomfortable thought gnawed at our minds that war is a universal concept and universally dreadful and that ... unfortunately ... evil resides in man. Quite possibly in any of us. And against all expectations, this Sanctuary has become a symbol and very telling sign that if I, you, 
any of us fail to control this evil that resides in us, it could reap an ominous harvest. And the Golgotha of the East ${ }^{145}$ is becoming a warning for us.

These blog comments show that these travelers learned the moral lesson inscribed in the Golgotha, where national memory is linked to religious memory by means of the notion of martyrology.

The moral instruction explicitly inscribed into the Golgotha's message is what distinguishes church-managed museums from typical historical museums ${ }^{146}$. However, it is worth stressing that people do not generally visit Kałków-Godów to acquire historical knowledge. They are more interested in learning how historical examples can be evoked to explain the essence of human suffering. Consequently, this history is introduced for purely illustrative purposes. It is a means to another end. The interpretations of the people connected with the Sanctuary constantly allude to the broad view of human suffering that forms the essence of the narrative this place presents. This was confirmed by one of the guides as she showed around a group of visitors: "This entire building is meant to help Poles regain their national and religious identity, but the main purpose of this place is to show concern for others, for their problems, in particular for the sick, the disabled and children" (F, ca. 35 years old, Kałków-Godów, November 2015).

The national marytrology is therefore becoming a form of suffering, but not the only one. The Sanctuary contains 10 homes for older people suffering from cancer and villages for orally and aurally challenged children (which accommodate about 80 people). It is a place of pilgrimage for orally and aurally challenged people from all over Poland, a place where sermons are delivered in sign language, of which the Sanctuary's founder and first custos had a firm command. Occupational therapy and vocational activation workshops for the disabled are also run from the Sanctuary complex. The church is a place of prayer for sick and missing children where anyone can hang a photograph of the child they are praying for on the church walls.

145 On their blog, they erroneously refer to the Golgotha of the Polish Nation as the Golgotha of the East. One of the oratories at the very bottom bears this name. However, the Golgotha as a whole is called the Golgotha of the Polish Nation.

146 Zuzanna Bogumił, "The Blessed Jerzy Popiełuszko Museum in Warsaw: Between History and Religion." Cultures of History Forum. 12.01.2018. http://www.cultureof-history.uni-jena.de//exhibitions/poland/the-blessed-jerzy-popieluszko-museumin-warsaw-between-history-and-religion/ (last accessed: 16 Sept. 2018). 
The manner in which the whole Sanctuary is organized demonstrates that suffering may affect individuals (when associated with illnesses, disability, family traumas, or the loss of loved ones) or communities. This communal aspect of suffering is divided into two further aspects, one passive and the other active: suffering derived from being affiliated to a national group (and therefore from the fate of that group and how it is defined by others) and suffering derived from actions undertaken for that group's benefit. All forms of suffering converge at one point established by the Christian history of salvation - Golgotha. As was previously mentioned, the Golgotha of the Polish Nation is surmounted by a cross which, as the guide explains during our visit: "is supposed to remind us that the history of our nation, our lives are interwoven with pain, suffering, with the Catholic faith, that death, death as painful, as cruel as the death of Jesus Christ on the cross is an indelible part of our lives" (F, ca. 35 years old, KałkówGodów, November 2015).

Such a broad, universal formula enables both the national and the vernacular (or individual) narratives to be incorporated into the Sanctuary. In stories about the Sanctuary's history, different kinds of narratives of suffering and martyrdom are not only cemented together by their theological dimension, but also by a human aspect - the biography of that place's founder. The biography of the prelate, Czesław Wala - and in particular his personal suffering and sensitivity to the suffering of others around him - appears as a narrative strand both in the accounts of guides and conversations with inhabitants of neighboring villages.

The narrative of his life might justifiably be classified as a mythic story of someone overcoming their suffering and that of others by focusing it on a single location marked by the salvific death of Christ. The priest suffered from tuberculosis from a young age. The same illness took his sister. His health was so bad that he struggled to graduate from his seminar $y^{147}$. Despite these misfortunes, he never gave up and tried to engage with his parishioners as closely as possible. During his pastoral visits, the priest not only encountered suffering that was caused by poverty or illness, but also by painful wartime experiences that were clearly closely linked to Poland's history. He gradually expanded the scope of his pastoral work, commencing with religious instruction for children organized at private homes, and later at the chapel, before ultimately going on to found a new parish and beginning to construct a church and a local Stations of the Cross surmounted by the Golgotha. It is clear from talking to the oldest villagers that their memories of the personal contributions they made to the Sanctuary's

147 Ryszka, Kałków-Godów. 
construction are still fresh, and they are still proud of what they managed to create and how many people their small village has begun to attract as a result of their efforts.

The manner in which today's narrative of the Sanctuary was constructed is also important for the people connected with the shrine. There were indeed plans from the outset for the Golgotha to resemble a medieval castle with a façade emblazoned with Polish coats of arms from various historical periods. However, individual oratories gradually began to appear inside it in response to public demand. Individuals or groups submitted their proposals for remembrances to be included within the Golgotha. The majority of these were not related to local history, and their very existence demonstrates the powerful influence the Sanctuary exerted far beyond the region where it was created. For example, it contains a chapel dedicated to the Warsaw Uprising devised by "people who actually participated in the Warsaw Uprising” (F, ca. 35 years old, Kałków-Godów, November 2015) as well as another chapel devoted to the nine miners from the Wujek Coal Mine shot by the security forces during the first days after the imposition of martial law in 1981. One of the guides made the following comment about this place: "due to firearms being employed, nine miners lost their lives. That's another cross in our history" (F, ca. 35 years old, Kałków-Godów, November 2015). The various chapels are therefore places of remembrance for those who gave up their lives for a national and/or religious community and values that were important to them, thereby becoming part of a sequence of events from Polish history that are presented at the Sanctuary as tragic yet ultimately victorious. As one of the priests stated, "The Golgotha is the element that identifies our sanctuary" (M, ca. 50 years old, Kałków-Godów, November 2015).

The Sanctuary and its individual remembrances play a dual role in the memory transmission process. The people behind the development of the individual oratories who actually participated in the events they commemorate chiefly perceive the Golgotha as a reminder of the past. At the same time, the Golgotha bears witness to the fact that they are fulfilling their duty to preserve the memory of these events. It allows them to consolidate their position within a shared vision of reality and strengthen their identities by constantly reminding them that the events they had participated in or witnessed were important enough to be incorporated into the Golgotha, thereby granting them the status of constitutive elements of the national history. It is these people in particular who are most interested in making pilgrimages to the Sanctuary. However, it is worth stressing that younger generations can also become active recipients of this narrative. For these people, this narrative provides an interpretative framework for reflecting on the past as well as national identity. 
Finally, it is worth noting that the Sanctuary's message is reinforced by the fact that it is located near the first sanctuary in Poland devoted to Relics of the True Cross. This was built on Święty Krzyż (Holy Cross Mountain), which is 20 kilometers from Kałków. According to the custos: "our Sanctuary is at the foot of Święty Krzyż, it's as if these places were meant to harmonize with each other on national, religious and patriotic grounds" (M, ca. 50 years old, KałkówGodów, November 2015). The connection between these two places was most clearly expressed by Father Zygmunt Zimowski, Bishop of Radom, in a speech he gave in 2007:

God is the best geographer, establishing chosen places as sanctuaries. Indeed, these words render very well the history of the foundation of the Marian sanctuary in KałkówGodów (...) From the hill in the Sanctuary, the dark massif of the monastery on Święty Krzyż can be seen. There, in the 10th century, stood the True Cross; here, ten centuries later, Mary, Mother of God "is demanding" her rightful place under the cross. She has also, in her own special way, acted as a patron for the works created here, as is reflected in the words of the awestruck papal nuncio Archbishop Józef Kowalczyk, spoken during a visit on 6 June 1993: "The development of this Marian site is a miracle of the 20th century ${ }^{148}$.

In this way, the Sanctuary narrative, even though it focuses on twentieth-century events, is being incorporated into the much longer histories of both the Polish state and Polish Catholic Church.

\section{Kałków-Godów as a Site of Memory for Peasants}

In 1997, the Polish People's Party (PSL) attempted to transform Kałków into a central site of memory commemorating the role Polish peasants played in Poland's history. In the same year, Wincenty Stawarz, grandson of Wincenty Witos $^{149}$ and honorary chairman of the Polish People's Party, came to Kielce to speak to Father Czesław Wala about how eminent activists from the people's movement were to be commemorated in the Sanctuary grounds ${ }^{150}$. They decided that the wall of the Golgotha of the Polish Nation would be an appropriate place

148 Quotation after: Ryszka, Sanktuarium pod Świętym Krzyżem, p. 7.

149 Wincenty Witos was a politician representing the peasants' party and three-time Prime Minister of the Poland. He became prime minister for the first time during the Battle of Warsaw in 1920, which was a turning point in the Polish-Soviet War.

150 Stanisław Durlej and Janusz Gmitruk, Panteon chłopów polskich na ziemi świętokrzyskiej. Kielce-Warsaw: Ludowe Towarzystwo Naukowo-Kulturalne Oddział w Kielcach, Muzeum Historii Polskiego Ruchu Ludowego, 2008, p. 39. 


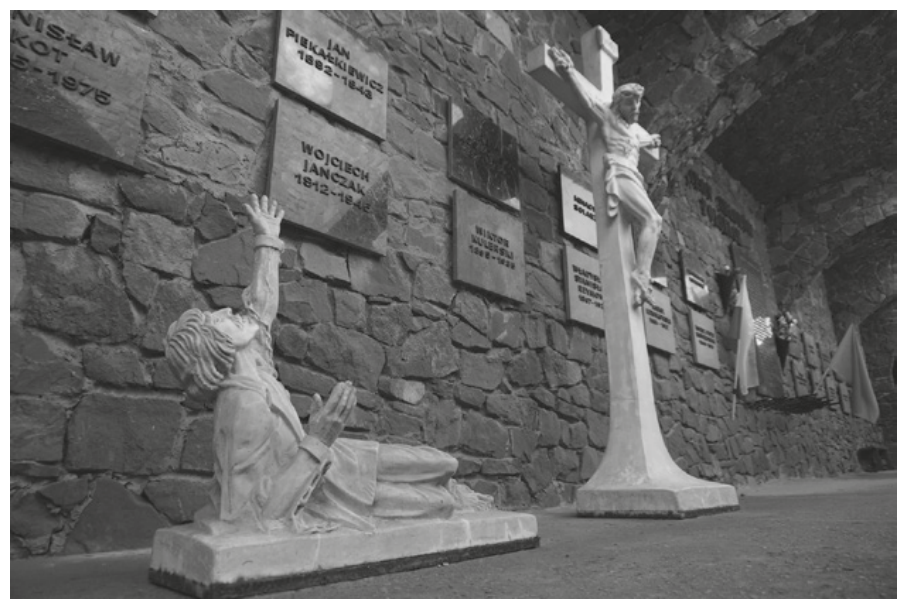

Fig. 1.7: The Pantheon of Polish Peasants in the Our Holy Cross Lady of Sorrows Sanctuary in Kałków-Godów. Photograph by Dariusz Bogumił.

to display commemorative plaques (Fig. 1.7). It was decided that a new plaque would be unveiled every year on 15 August - the anniversary of Peasant Action Day (Święto Czynu Chłopskiego).

This holiday dates back to the 1930s. It was established in 1936 by peasant movement activists as a symbolic response to the growing power of the Sanacja (Sanation) political camp concentrated around Marshall Józef Piłsudski. The date 15 August 1920 is recognized as the date of the victorious conclusion of the Battle of Warsaw, which brought the Polish-Soviet War to a close. The new holiday was established to highlight the role played by peasants and the leader of the people's movement, Wincenty Witos, in the victory over the Bolsheviks ${ }^{151}$. Sanacja propaganda attributed this victory to Józef Piłsudski’s military genius alone, but this interpretation provoked numerous controversies after the battle. Even the term used to describe the battle, "The Miracle on the Vistula", which has survived in Poland to today, initially had mocking overtones, since it implied criticism of Piłsudski's strategic capabilities ${ }^{152}$. However, given the coincidence that the date of 15 August happens to be shared by the Feast of the Assumption of

151 Durlej and Gmitruk, Panteon chłopów polskich.

152 Marek Tarczyński, Cud nad Wisłą. Bitwa Warszawska 1920. Warsaw: Instytut Wydawniczy Związków Zawodowych, 1990. 
the Blessed Virgin Mary, a very important holiday to the Polish Catholic Church, the national and religious elements of this day blended over time into one holiday emphasizing the exceptionality of this event from military, patriotic, and religious perspectives ${ }^{153}$.

The political situation in the Second Polish Republic was becoming so tense in the mid-1930s that a strike known in Poland as the Great Peasant Uprising broke out on the first anniversary of the newly introduced Peasant Action Day (15 August 1937). From 16 to 25 August 1937, peasants blockaded roads into cities, stopping food supplies and demanding both improvements in their social situation and domestic political change ${ }^{154}$. This was a mass protest led by the People's Party (SL) that involved several million protesters, mainly Polish, Belarusian, and Ukrainian peasants. It was the largest peasant strike in the interwar period yet had little impact on the policies being pursued by the government of the day ${ }^{155}$.

During the Polish People's Republic (PRL), there were no opportunities to commemorate an anniversary marking a victory over the Bolsheviks, but the anniversary of the Great Peasant Uprising was still celebrated. And the Catholic Church also continued to celebrate the Marian church holiday that shared the same date. Only when the post-PRL political transformation had already begun did it become possible to go back to commemorating the Battle of Warsaw, and on 15 August 1990, PSL's Supreme Council reinstated Peasant Action Day as well. As Gmitruk argues: "By re-establishing the celebrations, the [People's] Party leadership registered their opposition to the prevalence of unquestioning apologists within the sitting Solidarity government for the Sanacja policy and actions of Piłsudski and his supporters in 1920. By reevaluating the contribution of the peasants to the victory of 1920 , attention was brought to contemporary issues affecting the Polish countryside, which was bearing the highest costs of the political transformation"156.

Commemorating eminent peasants in a specially designed Pantheon in the grounds of the Marian Sanctuary where the Golgotha of the Polish Nation had been created seemed to be the perfect way to introduce memory of peasants

153 Marian, Marek Drozdowski, Warszawa w obronie Rzeczypospolitej. Czerwiec-sierpień 1920. Warsaw: Warszawska Oficyna Wydawnicza „Gryf”, Instytut Historii PAN, 1993; see also: Głowacka-Grajper, "Pamięć jako kapitał”.

154 Durlej and Gmitruk, Panteon chłopów polskich.

155 Wacław Wierzbieniec, Wielki Strajk Chłopski w 1937 roku. Uwarunkowania $i$ konsekwencje. Rzeszów: Wydawnictwo Uniwersytetu Rzeszowskiego, 2008.

156 Durlej and Gmitruk, Panteon chłopów polskich, p. 31. 
into the national history. All the more so, because memory of the patriotism displayed by peasants and the casualties they had incurred was marvelously suited to the Sanctuary narrative. The prevailing national memory narrative has been primarily created by the post-Solidarity intelligentsia of large cities who had adopted a narrative that marginalized Solidarity activists of peasant origin and memory constructs that failed to perceive the role peasants had played in Polish history as PSL's peasant activists did. The Pantheon of Polish Peasants in Kałków was therefore designed to counteract this marginalization and failure to remember.

The first plaque on the Pantheon was unveiled on 14 September 1997 on the sixtieth anniversary of the Great Peasant Uprising and Peasant Action Day. It bears the inscription "IN HOMAGE TO POLISH PEASANTS" and has been engraved with words spoken by Wincenty Witos, Stefan Wyszyński, and John Paul II about the role and importance of peasants in Poland's history. About seven thousand people came to Kałków for the first celebrations ${ }^{157}$. A speech was also given by Wincenty Witos' grandson, Wincenty Stawarz, who recounted the history of the Great Peasant Uprising and confirmed that from then on, the anniversaries of that event would be celebrated every year in Kałków.

Following Stawarz's death, Roman Malinowski, Marshall of the Sejm from 1985 to 1989, became an advocate and continuator of the remembrance in Kałków of eminent activists from the people's movement ${ }^{158}$. Over the years that followed, commemorative plaques of people who had rendered great service to the Polish countryside or people's movement were unveiled to mark Peasant Action Day or harvest festivals. They contained the names of the most distinguished politicians to emerge from the people's movement, including Wincenty Witos (three-time Prime Minister of Poland in the interwar period), Maciej Rataj (Marshall of the Sejm from 1922 to 1928), and Stanisław Mikołajczyk (Prime Minister of the wartime Polish government-in-exile from 1943). The annually unveiled plaques also commemorated the organizers of the peasant guerrilla resistance, educational activists, scientists of peasant origin, journalists, and members of cooperative movements.

Kałków-Godów has become the most important venue for the Peasant Action Day celebrations not only locally, but also across the country. Every year they are attended by representatives of PSL's top leadership. Even the Sanctuary's creator, Father Wala, when explaining why he had decided to become involved in this

157 Durlej and Gmitruk, Panteon chłopów polskich, p. 40.

158 Durlej and Gmitruk, Panteon chłopów polskich, p. 39. 
issue and support the idea of developing the Pantheon of Polish Peasants, said: "I love the Polish countryside and the whole of my forty-four-year life as a priest has been connected with the countryside. Anyone who does good in the countryside receives my wholehearted support. The Polish People's Party have done a great deal, and still do, for rural dwellers. That's why I'm happy that the plaques set into the Pantheon of Polish Peasants pay homage to and honor those who did good"159. These words clearly show that the Pantheon, which peasant activists treated as a political project designed to show how important the people's movement was to the Polish struggle for national liberation and provide them with moral capital in a political struggle, was, for Father Wala, another example of the narrative of human suffering and fortitude he had created.

The Pantheon of Polish Peasants' form is devoid of religious references. It comprises a row of rectangular plaques containing the names of the commemorated persons without any symbolic embellishment (Fig. 1.7). Nevertheless, the fact that the Pantheon is displayed on the wall of the Golgotha of the Polish Nation, within the Sanctuary, grants it a religious dimension. It appeared that such a form would appeal to rural communities regarded as relatively traditional and therefore more likely to identify with such a mode of presentation. At least that is how it appeared in 1997, when the project started to be developed. However, social transformations are also occurring in the countryside that are causing narratives of the past to be viewed in a new light. In particular, there has been a gradual reduction of interest in Kałków's Pantheon ${ }^{160}$ among members of the Polish People's Party (PSL), who are becoming increasingly involved in the development of another memory project, the Mausoleum of the Martyrdom of Polish Villages being created in Michniów, about 30 kilometers from Kałków. Nonetheless, in 2017, the Kałków celebrations were again attended by a high-ranking PSL representative (the Marshall of the Holy Cross Voivodeship, simultaneously serving as the party's deputy leader), while the leader of the same party celebrated the anniversary in front of a memorial to Wincenty Witos in Tarnów ${ }^{161}$.

159 Durlej and Gmitruk, Panteon chłopów polskich, p. 154.

160 Kazimierz Cuch, "Skromne święto Czynu Chłopskiego w Kałkowie". 15 Aug. 2015. Echodnia.eu., http://www.echodnia.eu/swietokrzyskie/wiadomosci/ starachowice/a/skromne-swieto-czynu-chlopskiego-w-kalkowie,10517228/ (last accessed: 10 Feb. 2018).

161 "Ludowcy upamiętnili Święto Czynu Chłopskiego." The official website of the Polish People's Party. 16 Aug. 2017. http://www.psl.pl/swieto-czynu-chlopskiego-2017-2/ 
Both places - Kałków-Godów and Michniów - use religious conceptions. Since religion is perceived as an important component of the cultural heritage of the local and national community, it is becoming a culturally sanctioned tool for the construction of narratives of the past. However, the manner in which these religious allusions are utilized is of crucial importance. At the Sanctuary in Kałków-Godów, the religious narrative dominates the narrative commemorating national history. The history of the nation is incorporated into the religious history of salvation and functions alongside other types of activity arising from the Kałków-Godów Sanctuary’s social mission. In Michniów, a modern secular state museum has been established that draws on religious conceptions yet it is historical representations that predominate there. Given the importance the Polish People's Party currently ascribes to both places, it would appear that this party's leadership believes that the museum in Michniów is better suited to introducing national history to communities of peasant origin than the Kałków Sanctuary with its Pantheon.

\section{The Power of Religious Memory}

Kałków-Godów's memory project intrigued us because this is clearly a place where religion prevails over both vernacular and national history. From a grand historical perspective, the Gębice and Żuchowiec pacifications of 1943 were two instances of the small-scale local exterminations that occurred in their thousands during the war. However, from the local community's point of view, these were events that transformed their lives forever. The few survivors and the murder victims' close family and relatives had to live on amid sites indelibly branded by the apocalypse they had suffered. This explains why they went to such pains to ensure that the deceased were commemorated in a dignified manner. The collective grave in the parish cemetery in Krynki was constructed to help bereaved villagers attain a sense of closure. It was just as important to mark sites where the tragedy had occurred with symbols protecting the community from these places' negative overtones, because, as ethnographers explain, such sites are perceived as safe.

For the communist authorities, the pacification sites provided even more historical evidence of the invaders' bestiality and were therefore exploited as such in the PRL's historical policy. This explains why, in the 1970s, a secular national

(last accessed: $10 \mathrm{Feb}$. 2018). The main ceremonies were held by this memorial to Wincenty Witos in the village of his birth, Wierzchosławice - a village near Tarnów. 
memorial was erected at the main murder site of the May 1943 pacification, thereby incorporating these sites into a national network of Sites of Memory of the Struggle and Martyrdom of the Polish Nation. This local history has been incorporated into national history as one of thousands of examples of wartime martyrologies.

Over time, the local community erected religious memory markers in an attempt to sacralize secular monuments dating from the PRL. One of these monuments, a statue of Our Lady, Queen of Poland, became a focal point of vernacular remembrance ceremonies. However, in 2017, a post on a local online news service noted: "The local authorities presiding over the communes of Pawłów, Brody and Kunów and Starachowice County have ignored the seventyfourth anniversary of the pacification of villages located in their communes"162. Someone did in fact write in a comment that, rather than totally ignoring them, they had gone to the site of "the grave of all the murder victims rather than just the memorial". Nevertheless, the manner in which the seventy-fourth anniversary of the pacification was observed in Kałków-Godów differed markedly from the approach in Michniów, where the local community created their own memory rituals marking the anniversaries of the pacification of their village, which have been consistently observed for many years (see the case study on Michniów).

As we have shown in this chapter, memory of the 1943 pacifications is transferred orally and primarily functions within the local community as memory of deceased close family members and relatives. Consequently, on the victims' grave and by monuments including the memorial in the Sanctuary grounds, one can still find candles acting as testimonies to someone's memory. The pacifications have not attained the form of an identity-changing event that would allow them to endure in cultural memory as an important event from the past. The sacred nature of the sites of memory commemorating the pacification is becoming increasingly evident as they blend into the religious landscape of the Holy Cross region.

This same process is occurring within the Sanctuary. It was created as a response to a very concrete historical event - the imposition of martial law in 1981. By contrast, the Golgotha of the Polish Nation was a very concrete

162 KazimierzCuch, "Uroczysta rocznicapacyfikacjiŻuchowcaiGębic. Władzezlekceważyli wydarzenie.” Echodnia.eu. 29.May.2017, http://www.echodnia.eu/swietokrzyskie/ wiadomosci/starachowice/a/uroczysta-rocznica-pacyfikacji-zuchowca-i-gebicwladze-zlekcewazyli-wydarzenie,12124324/ (last accessed: 10 Feb. 2018). 
contemporary response to both PRL-era historical policy, which excluded many social groups from national memory, and the memory environment of the 1990s, when these excluded groups found their voice and began fighting for their story to be incorporated into the history of the nation. This explains why the portrayal of the past at the Sanctuary does more than simply show the history of all these marginalized social categories. It is mainly focused on these social groups' incorporation into a national history concentrated around motifs of suffering and victory being achieved through making sacrifices for the common good. This is achieved by creating narrative frameworks enabling the history of all these people to be related as history common to all. The proposed narrative, based on the fate of individual groups being interpreted as an instance of the martyrology of the Polish nation, was not a new innovation. Instead, it was a reactivation of a conceptual structure rooted in Polish culture that draws from Catholic models. At a time when other structures able to comprehensively explain events from the recent past were yet to be created, such an approach appeared to be an authentic and convincing modus operandi. The message was further reinforced through the authority of the Catholic Church, which various opposition circles regarded at the time as a guardian of the History of the Nation.

The Golgotha narrative is primarily of national purport since it relates to the presentation of a cohesive vision of Poland's most recent history within the general context of a history of salvation. The prevalence of this particular context means that the local community's primary concern is not to get their history incorporated into the Golgotha narrative. However, all the commemorations of the Second World War pacification do in fact allude to the same religious context of a history of salvation. These sites are therefore not in competition with each other either spatially, socially (i.e., in relation to the communities they serve) or in terms of their manner of interpretation (all of them show innocent victims and the enemy's bestiality). Instead, they function alongside each other. The ceremonies at local sites of memory only attract people united by family ties to the pacified villages, whereas the pilgrims and tourists visiting the Sanctuary primarily focus on its national-religious and vernacular dimensions.

The Sanctuary's growing importance in the 1990s and the eloquence of its project led the Polish People's Party and local government activists (often identifying with the same party) to decide to make use of this site as a space through which they could introduce the narrative of the history of the peasants as a social class to the history of the Polish nation. Their idea came to form part of the Sanctuary's mission which was underscored with the notion of granting a voice to those who had been deprived of one for many years. The peasant movement's primary concern was to contest the principles of social exclusion inherent in the 
narrative of the nation created by the intelligentsia. However, the creation of the Pantheon of Polish Peasants and revival of Peasant Action Day did not lead to peasant memory becoming a component of national memory. This phenomenon can be accounted for in a number of ways, including the effects of a transformation in methods of relating the story of the past, which was accompanied by its estheticization. Traditional forms of presentation have lost their appeal and persisting narratives of the past will have to change ${ }^{163}$. However, such changes are highly unlikely to be adopted at Kałków-Godów because this place primarily caters for cult worship rather than the learning of history. The Golgotha or the Pantheon merely serve as symbols of human suffering and fortitude ${ }^{164}$. This explains why it is so difficult for peasant activists to make use of the Pantheon of Polish Peasants in their party's historical policy.

It should be stressed that the entire Sanctuary, which started out as a very political and socially relevant memory project, is increasingly becoming a project that is purely religious. The religious framework that turned the Sanctuary into an appealing memory project is making a continuous impact on visitors even when they are not coming as pilgrims. This makes sense because, as Maurice Halbwachs wrote, religious memory is distinctive for its ability to incorporate new motifs, albeit on the condition that they can be adapted to suit the needs of religious doctrine ${ }^{165}$. A notable consequence of this process, as applied to Kałków-Godów, is that the commemoration of peasants, much like that of the 1943 pacification, is progressively being transformed into another layer of the vernacular religious landscape, a landscape whose roots date back to the tenth century, when Poland's first sanctuary was established in this region.

163 Zuzanna Bogumił and Andrzej Szpociński (eds.), Stare i nowe tendencje w obszarze pamięci społecznej. Warsaw: Scholar, 2018.

164 It is Poland's sixth most popular pilgrim destination after Jasna Góra, Licheń Stary, Łagiewniki in Kraków, Kalwaria Zebrzydowska, and Niepokalanów. See: Durlej, Gmitruk, Panteon chłopów polskich, p. 11.

165 Maurice Halbwachs, On Collective Memory. Chicago: Chicago University Press, 1992, p. $81-117$. 



\section{Michniów}

The bill of indictment placed before the International War Tribunal in Nuremburg [not only] contains a synthesis of the crimes committed by Nazi Germany, but also mentions the destruction of towns and villages and murder of their inhabitants in Europe's occupied territories. As was indicated, the Nazis committed these crimes without any "justified military need". The Nuremburg document mentions the destruction of several villages in France, Greece, and Yugoslavia and the Czech village of Lidice. (...)

The Nuremburg act of indictment does not contain any data about the Polish villages destroyed by the occupying forces or their murdered inhabitants. Yet it was only under German occupation that over 800 villages on Polish soil were pacified, 180 of which were burned to the ground. This is a silent page, as it were, in our history under occupation. In Europe, and even among us Poles, the Nazi crimes committed on our soil are most often associated with Auschwitz. It was only a few years ago, when the notion was popularized of constructing the Mausoleum of the Struggle and Martyrdom of the Polish Village in Michniów, that the tragic fate of this village in the Świętokrzyskie (Holy Cross) Voivodeship which was leveled to the ground in July 1943 grew to symbolize the martyrdom of all the Polish villages in Central Poland and the Eastern Borderlands during the Second World War.

Thus wrote Janusz Gmitruk, Director of the Museum of the History of the Polish Peasant Movement, in his introduction to the catalog for the Płonety niebo $i$ ziemia (Heaven and Earth in Flames) exhibition ${ }^{166}$. Let us, therefore, trace the path taken by Michniów from a village that was leveled to the ground and absent from Polish - let alone global or European - memory narratives to the objective set for it by local memory actors and activists of the peasant

166 Janusz Gmitruk and Longin Kaczanowski, Płonęły niebo i ziemia/Mauzoleum Walki i Męczeństwa Wsi Polskiej w Michniowie. Warsaw and Michniów: MHPRL, 1998. 
movement, namely for it to become the most important, nationally and globally recognized symbol of the fate of inhabitants of Polish villages during the Second World War.

\section{Michniów During the Second World War}

The small village of Michniów lies on the outskirts of the Sieradowice Landscape Park, on the road linking the towns of Suchedniów and Bodzentyn. According to data presented in the National Census, it had 439 inhabitants in 2011. In June 1943, when the village was wiped from the face of the earth, there were 535 inhabitants ${ }^{167}$.

This was an area already occupied by the Germans at the beginning of September 1939 - the first days of the Second World War. In 1942, Michniów also became the first place to witness a mass execution by firing squad, when the German military police shot 17 people of Roma ethnicity there. Their names have never been established ${ }^{168}$. However, this event is not commemorated in any shape or form; it also fails to appear in any memory narratives, whether they be oral reminiscences, articles, or books about this village's wartime fate.

Partisan units appeared around the village from the first years of the German occupation. A Home Army platoon codenamed Kuźnia (lit. The Forge), which numbered around 40 people, was based at Michniów, and around the end of 1942, the Kielce Land division of the Gwardia Ludowa (lit. People's Guard) also began operating in the area ${ }^{169}$. At the beginning of 1943, the Home Army Central Command created the Directorate of Sabotage (Kedyw) and began organizing the operations of Kedyw detachments across occupied Poland. The mission to create such a detachment in the Kielce Region was entrusted in May 1943 to Lieutenant Jan Piwnik, whose pseudonym was Ponury (lit. Glum, Gloomy). He arrived at Michniów and made contact with local partisan units, which he gathered together at the Wykus rallying point, which was a nature reserve in

167 Longin Kaczanowski, Zagłada Michniowa. Warsaw: Muzeum Historii Polskiego Ruchu Ludowego i Muzeum Wsi Kieleckiej, 2013, p. 161. Michniów’s wartime fate has been the focus of many studies written for an academic and popular readership and press articles, see Tomasz Domański, "I nie widziałem ich więcej wśród żywych..." Pacyfikacja Michniowa 12 i 13 lipca 1943 r. w dokumentach i relacjach. Kraków: IPN, 2013.

168 Rejestr miejsc i faktów zbrodni, p. 150.

169 Kaczanowski, Zagłada Michniowa, pp. 31-32. 
the Siekierczyńskie Woods, just outside Michniów. At the briefing held on 12th to 13th June, an appropriate division of tasks between the individual units was established and it was decided that Ponury would direct all diversionary sabotage operations ${ }^{170}$. The Ponury detachment experienced its martial baptism on the night of 2nd and 3rd July, when it attacked two trains carrying German soldiers traveling from Kraków to Warsaw. Eight people were killed and around 30 or 40 injured. On 8 July, at an extraordinary meeting in Radom, the Germans decided to take action against the Michniów "bandits". The villagers were probably denounced by a traitor, normally identified as the Gestapo agent Jerzy Wojnowski, whose pseudonym was Motor (lit. Engine, Driving Force), though it is not entirely clear if it was he who had passed on information to the Germans about the Michniów villagers' involvement in partisan operations. On 11 July, German officers performed a reconnaissance in the village ${ }^{171}$. That same day, a dozen or so hours before the Michniów Pacification, newly accepted recruits to the Ponury detachment took their military oath ${ }^{172}$.

On 12th July 1943, units of the German Ordnungspolizei (OrPo) and Sicherheitspolizei (SiPo, of which the Gestapo was a suboffice) entered the village and arrested people accused of collaborating with the partisans or belonging to the Underground ${ }^{173}$. The Germans drove the men out of their homes and verified their names on pre-prepared lists. They then took them to five barns in the village. Some were shot with rifles, and others were blown up by grenades or burned to death. The Germans set fire to all the barns. The families of Władysław Materek and the forester Władysław Wikło were also shot and burned. That day, the Germans murdered 96 men, two women, and five children. Another 27 people were deported from the village, 18 of them, all women, being sent to forced labor camps in Germany, while the rest were imprisoned before being sent to concentration camps ${ }^{174}$. Only three of the latter were rescued; the other six died at Auschwitz ${ }^{175}$. On the day of the pacification, most of the village's buildings were plundered and then burned.

When news had spread of the events in Michniów, a group of Wykus partisans under the command of Jan "Ponury" Piwnik set off for Michniów. When they

170 Kaczanowski, Zagłada Michniowa, pp. 42-46.

171 Tomasz Domański and Andrzej Jankowski, Represje niemieckie na wsi kieleckiej 19391945. Kielce: IPN, 2011, p. 206.

172 Kaczanowski, Zagłada Michniowa, pp. 53-54.

173 Domański, I nie widziałem ich więcej, p. 28.

174 Domański, I nie widziałem ich więcej, pp. 28-30.

175 Kaczanowski, Zagłada Michniowa, p. 203. 
reached their destination, the German units had already departed. Having decided on reprisals, on the night of the 12 and 13th July, the partisans carried out an attack on a German train, probably shooting dead around 180 Germans ${ }^{176}$ before daubing the words "For Michniów" on its carriages ${ }^{177}$.

This partisan action met with an immediate response from the Germans. On 13th July, the Germans reentered Michniów, this time murdering everyone they came across in the village's buildings. The same day, all the homes and buildings that remained were burned to the ground. Over the two days, 204 villagers died ${ }^{178}$. The youngest victim, Stefan Dąbrowa, was only nine days old. The only survivors were those who had managed to flee Michniów ${ }^{179}$. Not until the fifth day following the pacification were the murder victims' families allowed to bury their remains. It was only then that a collective grave was created on a plot of land belonging to a school. The charred bodies were buried in containers that had survived the fires rather than coffins. Despite granting permission for the victims' burial, the Germans did not consent in the end to the grave being marked with a cross or any other marker and ordered that the ground be plowed over ${ }^{180}$. The German authorities not only forbade the villagers from rebuilding their village or cultivating the surrounding fields but also shot anyone found on the land it used to occupy or returning to their fields. In fall 1944, after the terrain had been liberated from German occupation, the first families returned to the village. The other villages did not return until the Third Reich's capitulation $^{181}$. These returnees began rebuilding the village and took action to commemorate those who had fallen victim to the pacification.

\section{The History of the Michniów Pacification's Memorialization}

Just a few days after the Michniów Pacification, partisans and scouts began spreading information about the German crime. The first campaign was

176 This is the number given by Polish sources. According to German sources, 5 people died and 14 were injured, Domański, I nie widziałem ich więcej, pp. 30-31.

177 Domański, I nie widziałem ich więcej, pp. 30-31.

178 There were probably more victims. Two hundred and four names have been identified as belonging to Michniów residents, but the victims could have also included people from other villages who happened to be in Michniów that day. Their number has been estimated as 20, see Kaczanowski, Zagłada Michniowa, p. 135.

179 Domański, I nie widziałem ich więcej, pp. 31-32.

180 Kaczanowski, Zagłada Michniowa, p. 97.

181 Domański, I nie widziałem ich więcej, p. 32. 
organized by the Gray Ranks ${ }^{182}$ of the First Suchedniów Scouting Troop. Placards were placed on both sides of the railway line, just before fast trains passed, which contained such slogans (in German) as "SS units murdered 200 women and children here, in the village of Michniów, and burned down the village" or "Deutsche Katyn"183. Information about the pacification appeared in the underground press in the Holy Cross region.

The partisans created many poems and ballads based on Michniów's fate, some of which are still familiar to, and continue to be performed by, today's inhabitants of Michniów and the surrounding region. The On Killing and Burning songs, created by the poets who formed part of almost every partisan unit as well as folk artists, together constitute an important ethnographic record of wartime events ${ }^{184}$. Michniów inspired four songs published in 1946, shortly after the war in the On the Partisan Trail. Remembering Michniów collection: Odwet Michniowa (The Michniów Reprisals), composed by Corporal Michał "Mściciel" ("The Avenger") Bas; Na zgliszczach Michniowa (In the Ashes of Michniów), created by a soldier with the pseudonym Olsza; Orle Gniazdo (The Eyrie), composed by Corporal "Strach" (Fear) and Pieśń o Michniowie (Song of Michniów), composer unknown ${ }^{185}$. The last of these has become the best known and is still sang today. Much as was the case with the military campaigns of the Gray Ranks scouts, its creator alluded in it to the Katyn Massacre. The song's first verse goes like this:

Michniów! Michniów! A Katyn happened in you,

$O$ wretch that I am, I once roamed around you.

You, village by a wood, Motherland to soldiers,

Let everyone see what corpses now there do lie.

The volume it was published in contains the date 26 July 1943, but the song was probably created earlier, because it is referenced in the ballad Orle gniazdo, which was composed on 18 February 1943. Information about the Katyn crime could have been passed on by Ponury's soldiers or by the commander himself because they came from a disbanded unit from the area around Pinsk (a city

182 The codename of the underground paramilitary Związek Harcerstwa Polskiego (Polish Scouting and Guiding Association).

183 Domański, I nie widziałem ich więcej, p. 33; Kaczanowski, Zagłada Michniowa, p. 149.

184 Helena Wolny, "Pieśń ludowa epicka jako obraz i utrwalenie wydarzeń autentycznych o martyrologii wsi polskiej w latach 1939-1945.” In: Druga wojna światowa w literaturze polskiej i obcej, ed. Lech Ludorowski. Lublin: Wydawnictwo UMCS, 1992, pp. 125-126.

185 Kaczanowski, Zagłada Michniowa, p. 152. 
under Soviet occupation until June 1941). Apart from this source, information about the Katyn crime gradually found its way from the London governmentin-exile to soldiers of the Home Army and other partisan units and scout troops. In all likelihood, Song of Michniów was composed by a member of a partisan unit who knew enough about what had happened in the Katyn forests to employ the name "Katyn" as a symbol of mass crime. He was also familiar with a song providing a setting to the words of a poet from the Romantic era, Wincenty Pol, because he alludes to this song in his own ${ }^{186}$. This song inspired the creation of many other folk songs and poems (including the song Tragedia Michniowa [The Tragedy of Michniowa] composed by the folk poets Rozalia and Wojciech Grzegorczyk). As Helena Wolny observes: "All these songs are almost mini chronicles giving an exact date, time and place and, more often than not, people's names and a crime trajectory. (...) These songs function as universal, anonymous compositions. They were adopted by the people as their own"187. The eyewitness accounts and songs circulating around the region's villages and towns were not only extremely important tools for the transmission of memories of wartime events but also appealed to the generations that followed. They played a crucial role in preserving information about the course of events in each town or village, but their words or lyrics also alluded to other places and historical events (both Second World War events, such as those taking place in Katyn, Auschwitz and Majdanek, and earlier battles against the Germans or the Order of Teutonic Knights), which placed local history within the broader context of national history. These songs also contained many religious motifs, which reference, in turn, Catholic visions of the sacrifice of innocents or the justice that would, over time, visit itself upon every wrongdoer.

In Michniów itself, the most important site of memory, both in the first months after the war and today, is the collective grave of victims of the pacification, which is in the village center (Fig. 2.1). The plot containing the grave where the victims' remains were laid a few days after the pacification was tended to as soon as the war finished. Michniów's surviving inhabitants and the families of those who had been murdered organized a collection, overseen by Adolf Morawski, the village leader, to raise money for a memorial. People donated both money and produce from their farms ${ }^{188}$. Over the grave, a red sandstone monument was erected with the victims' names engraved on it. An inscription in the

186 Wolny, Pieśń ludowa epicka, pp. 130-134.

187 Wolny, Pieśń ludowa epicka, p. 139.

188 Gmitruk and Kaczanowski, Płonęły niebo i ziemia, p. 95. 


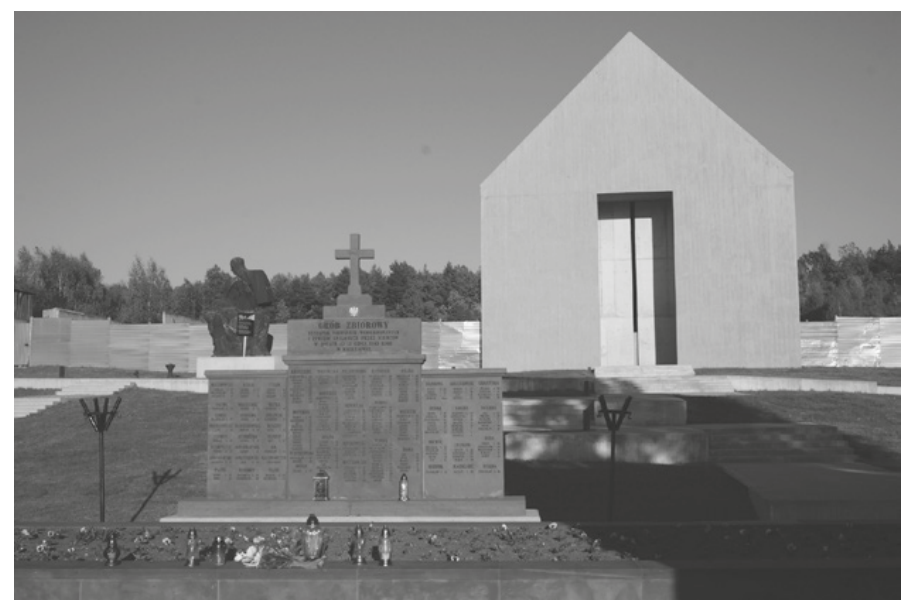

Fig. 2.1: The collective grave of victims of the pacification that took place in Michniów on 12th-13th July 1943. The inscription provides the following information: "The collective grave [containing] the remains of those undeservedly murdered and burned alive by the Germans on the 12th and 13th July 1943 in Michniów". In the background, the Mausoleum of the Martyrdom of Polish Villages in Michniów is visible. Photograph by Dariusz Bogumił.

center of the memorial reads: "The collective grave [containing] the remains of those undeservedly murdered and burned alive by the Germans on 12th and 13th July 1943 in Michniów." The upper part of the memorial contains Poland's coat of arms - a white eagle with a cross above it inscribed with the word "Pax". Over the following years, a fence was constructed. The memorial has remained unchanged to the present day. When people began resettling the village, the village leader submitted a request for aid, which he was granted, to the President of Poland, Bolesław Bierut. The money was distributed among those families that had lost their homes because of the pacification. However, 13 families had been completely wiped out. It was, therefore, decided that the money that would have been destined for them should be allocated toward the cost of building a new school. Consequently, the school building itself became an indirect reminder of the extermination that had taken place in the village. The construction work began on 1 September $1953^{189}$. In the 1950s, a small brick chapel dedicated to St Margaret was erected next to the collective grave (Fig. 2.2). It served as a religious

189 Kaczanowski, Zagłada Michniowa, p. 160. 


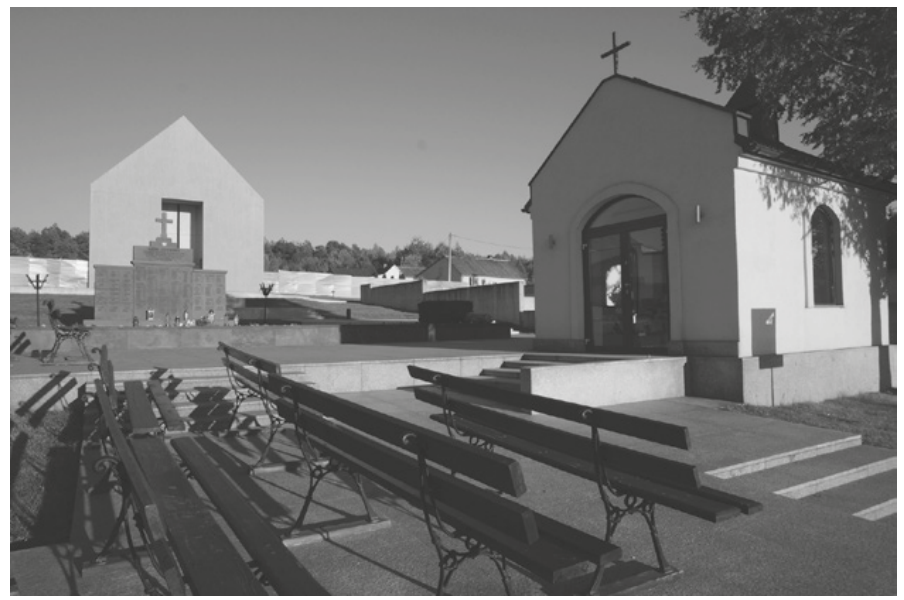

Fig. 2.2: The small brick chapel to the right, which was dedicated to St Margaret, was erected next to the collective grave in Michniów in 1953. Photograph by Dariusz Bogumił.

education and prayer room. People also gathered by it during the religious ceremonies on every anniversary of the pacification.

Vernacular memory of the Michniów pacification impressed itself very deeply. It also had its own infrastructure, which assumed both a material (the collective grave and memorial) and non-material (anniversary ceremonies, folk songs) form. Nevertheless, on a national level, the policy pursued by the authorities of the People's Republic of Poland meant that the events in Michniów were barely remembered at all. In fact, they strove to erase the memory of the Home Army from public consciousness. Michniów was an important center of support for the operations of the Home Army partisans (both logistically and personally - it was from this village that many of the partisans came), so it became an "inconvenient" site of commemoration from the point of view of state historical policy. In 1956, after the communist regime had softened its stance and announced amnesties for incarcerated Home Army (AK) members, a former AK soldier from Michniów, Hipolit Krogulec, submitted a proposal for the village to be granted Poland's highest military honor - the Virtuti Militari Cross - but the authorities did not respond. The village's AK past still lay heavily on $\mathrm{it}^{190}$.

190 Gmitruk and Kaczanowski, Płonęty niebo i ziemia, p. 71. 
Nonetheless, immediately after the war, the Polish state took punitive action against those who had perpetrated German crimes, including the Michniów Pacification, in occupied Poland. However, only two people were sentenced: Julian Hein, a direct participant in the pacification, in February 1946, and Herbert Böttcher, commander of the SS and Police in the Radom district, in June 1949. Both were sentenced to death ${ }^{191}$.

It was not until 24 May 1968 that the Kielce District Commission for the Investigation of Nazi Crimes in Poland commenced an official investigation into the Michniów Pacification case under the direction of Justice Andrzej Jankowski. An inspection of the crime scene was carried out in the village, and the testimonies of 35 witnesses and previously unknown German documents were collected. These materials, when combined with witness testimonies taken at trials that took place in the second half of the 1940s, constitute the basic material for reconstructing the course of events in Michniów. However, the investigation was suspended on 21 May 1976, because all the perpetrators of these crimes lived outside Poland, which made it impossible to arraign them before Polish courts.

In the late 1960s and early 1970s, when state policy began to more closely reflect the social situation in Poland, acts commemorating Michniów's wartime fate grew in intensity. On the one hand, the Polish state took action by commencing numerous investigations into German crimes (since these fell under a statute of limitations due to expire in Germany on 8 May 1965) and carrying out a nationwide campaign promoting the erection of memorials at sites associated with the Second World War. On the other hand, there were exceptional social circumstances at this time - the first post-war generation were reaching maturity and those who had survived the war as adults were entering the postproductive stage of their lives and beginning to take on the role of grandparents (creating favorable conditions for family histories to be passed on to the generations succeeding their own).

In 1970, local writer and sculptor Ryszard Miernik published Pieśń o Michniowie (Song of Michniów), which was illustrated by Henryk Papierniak and based on the first anonymous composition from the war and a poem by the folk poets Rozalia and Wojciech Grzegorczyk ${ }^{192}$. This text was set to music by Mirosław Niziurski, and the resulting cantata was premiered by the Kielce Philharmonic and State Music Schools Choir in Kielce, conducted by Henryk

191 Domański, I nie widziałem ich więcej, pp. 33-34.

192 Ryszard Miernik, Pieśń o Michniowie. Łódź: Wydawnictwo Łódzkie, 1970. This poem was republished in 1974 and again, for a third time, in 1983. 
Gostomski. It was also Ryszard Miernik's idea to erect a memorial in Michniów commemorating the pacification. It was designed by folk sculptor Adam Zegadło. However, these plans were never implemented ${ }^{193}$.

In 1971, a Hall of Memory, also described as a Hall of National Remembrance, ${ }^{194}$ was created in the Farmers' Club in Michniów, where it was tended to by one of the villagers who had survived the pacification - Maria Grabińska. In 1977, Michniów finally won recognition on a national scale, when the Council of State awarded the village a Third Class Order of the Cross of Grunwald. The ceremony at which the village was awarded this honor took place in July 1977, but not on the anniversary of the pacification. Instead, it took place on July 22 - the date which the communist authorities had established as National Rebirth of Poland Day. The occasion was marked in Michniów with large-scale ceremonies attended by around 15,000 people from the whole district. That same day, a new exhibition prepared by the National Museum and District Commission for the Investigation of Nazi Crimes in Kielce was opened in the Hall of National Remembrance, which had been transferred to a wooden house formerly belonging to the Grabiński family ${ }^{195}$. The Cross of Grunwald the village had just been awarded was also placed in the Hall. In the late 1960s and early 1970s, Michniów, the Hall of National Remembrance that functioned in it and the collective grave with its memorial also became a frequent destination for outings organized by the Polish Tourist and Sightseeing Society (PTTK), and a description of the village could be found in guides the PPTK published ${ }^{196}$.

In 1979, the Main Commission for the Investigation of Nazi Crimes first came up with the idea of creating a Mausoleum of the Martyrdom of Polish Villages ${ }^{197}$. In April 1981, this idea won support in a joint declaration by the chairman of the $\mathrm{ZBOWiD}^{198}$ national veteran organization, Leon Pająk and head

193 Kaczanowski, Zagłada Michniowa, pp. 165-166.

194 Ewa Kołomańska, Michniów. Mauzoleum martyrologii wsi polskich. Kielce: Muzeum Wsi Kieleckiej, 2010: 18.

195 Kaczanowski, Zagłada Michniowa, p. 162; Tadeusz Obara and Stanisław Durlej, Męczeństwo i pamięć. Kielce: Ludowe Towarzystwo Naukowo-Kulturalne, 2001: 130-131.

196 For example, Jankowski, Andrzej and Włodzimierz Sadowski, Kielce i okolice. Przewodnik. Warsaw: Sport i Turystyka, 1983.

197 Kołomańska, Michniów, p. 19.

198 Związek Bojowników o Wolność i Demokrację (Society of Fighters for Freedom and Democracy). For the history of this organization, see: Joanna Wawrzyniak, Veterans, 


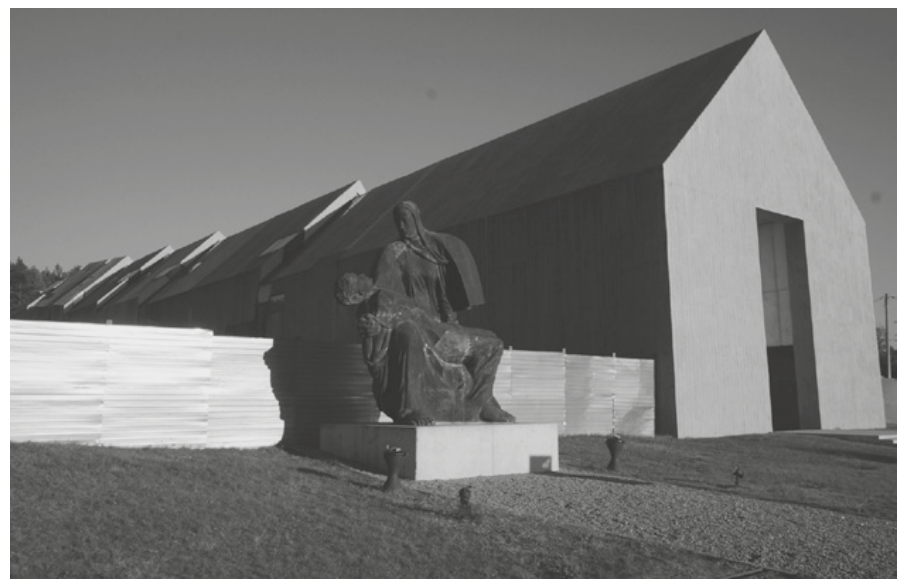

Fig. 2.3: Pieta Michniowska (The Michniów Pieta) erected in 1993. In the background, the Mausoleum of the Martyrdom of Polish Villages in Michniów is visible. Photograph by Dariusz Bogumił.

of the PTTK's Kielce branch, Zbigniew Chodak. However, following the imposition of martial law in Poland in December 1981, there were no longer any opportunities for developing this idea. But it was returned to in 1984, after the lifting of martial law, when the Organizing Committee for the Construction of a Mausoleum of the Struggle and Martyrdom of the Polish Village in Michniów was created, with Leon Pająk as chairman. Contributions to the Mausoleum's creation were also made by the peasants' party, which operated as the Zjednoczone Stronnictwo Ludowe (The United Peasants' Party) during the People's Republic of Poland. The party's chairman, Roman Malinowski, who was also Marshall of the Sejm, chaired the Honorary Committee for the Mausoleum's Construction. A competition was announced for the best design and the winning entry, titled Pieta Michniowska (Michniów Pieta), was selected in 1987 (Fig. 2.3). The design was meant to comprise three monumental sculptures and an underground sanctuary as well as a museum consisting of five parts. The design as a whole was on a monumental scale. It was planned that it would occupy as many as $2.5 \mathrm{ha}^{2}$. The mausoleum was supposed to open in 1993, on the fiftieth anniversary of the pacification. However, the escalating financial crisis and economic, social

Victims, and Memory. The Politics of the Second World War in Communist Poland. Translated by Simon Lewis. Frankfurt a.M.: Peter Lang, 2015. 
and political transformations provoked by the dismantlement of the communist system, which began after the June 1989 elections, meant that the idea was never implemented ${ }^{199}$. In the meantime, the Michniów Pacification was taken up as a theme by a Polish documentary maker. In 1986, a film titled 203 sprawiedliwych (The Righteous 203) was released, which was directed by Józef Gębski and won the Professional Prize at the Kraków Film Festival.

The idea of constructing a mausoleum also continued to be attractive for the changing peasants' party. At the unification congress in May 1990, at which Polskie Stronnictwo Ludowe (PSL, the Polish People's Party) was established, a resolution was adopted that highlighted the need to construct a mausoleum in Michniów. In January 1991, a new Organizing Committee for the Construction of a Mausoleum was established, which was presided over by the chairman of the Kielce chapter of PSL, Alfred Domagalski, and four months later, on May 9th, the Memorial-Mausoleum Fund was created in Michniów. However, the collected funds were only enough to finance the construction of the Pieta Michniowska memorial, which was designed by Wacław Stawicki and unveiled in July $1993^{200}$.

Apart from ideas for the construction of the mausoleum, other ideas appeared in the mid- eighties for commemorating the Home Army partisans who had operated in the Holy Cross region, in particular, the commander of the local Ponury partisan detachment and the foresters who had assisted them. In July 1986, a monument to the foresters who perished for assisting the partisans during the Second World War was unveiled in the woods near Michniów. The inscription on the memorial reads: "In remembrance of the foresters from the Holy Cross Forest who fell in combat against the Nazi invader or were murdered in the extermination camps and the pacifications of the village. The staff of the Suchedniów Forestry Commission and the OZLP Directorate"201. In 1987, Ponury's ashes were brought from the Navahrudak region, where he died, to the chapel at a monastery in Wąchock. In June 1988, his coffin was borne in a cortège past sites associated with the partisan activity, including the partisans' old rallying point at the Wykus nature reserve. After this, Ponury's funeral was held in the monastery's crypt ${ }^{202}$.

Following this, the Memorial-Mausoleum Foundation obtained funding from the Foundation for Polish-German Reconciliation and constructed a Hall of

199 Kaczanowski, Zagłada Michniowa, pp. 167-171.

200 Kaczanowski, Zagłada Michniowa, pp. 176-177.

201 OZLP - Okręgowy Zarząd Lasów Państwowych (District National Forest Administation).

202 Gmitruk and Kaczanowski, Płonęły niebo i ziemia, pp. 72-73. 
Memory ${ }^{203}$, also known as the House of National Remembrance ${ }^{204}$. The Hall of Memory's ceremonial opening in July 1997 was accompanied by the erection of the first crosses on a hill behind the Pieta, thereby starting off the process of turning the site into Michniów's Golgotha (also known as The Forest of Crosses). The plan was ultimately to erect crosses to commemorate all the villages in Poland pacified during the Second World War, and crosses were brought to Michniów by delegations from other pacified villages. These actions showed that inhabitants of Polish villages had begun to perceive Michniów as a central site of memory commemorating the fate of wartime peasants. The ceremony was attended by the incumbent chairman of the Polish People's Party, Waldemar Pawlak. The following year, during the next anniversary, the Heaven and Earth in Flames exhibition was opened at the Hall of Memory ${ }^{205}$.

In 2003, for the first time, a connection began to be officially made between the pacifications carried out by the Germans and the massacres inflicted on Polish villages in Volhynia and eastern Lesser Poland by the Ukrainian Insurgent Army (UPA). These two events coincided - the events in Volhynia reached their climax on 11 July 1943, so-called "Bloody Sunday", while the Michniów Pacification began the following day. The two crimes were explicitly linked in speeches to mark the sixtieth anniversary of the events, delivered in Michniów by the PSL chairman, Jarosław Kalinowski and the President of Poland, Aleksander Kwaśniewski, who was attending ceremonies of remembrance in Volhynia on the same day ${ }^{206}$. The following year, a monument titled The Volhynia Conflagration, which was funded by veterans of the Home Army's 27th Volhynia Infantry Division, was erected in the grounds of the future mausoleum. In 2006, another monument was unveiled at the site as a gesture of gratitude for the help the village's population had provided to partisan soldiers ${ }^{207}$.

Since 2008, the mausoleum has been co-owned by the Kielce District Countryside Museum, which has been implementing a historical education program incorporating museology lessons, publications, and exhibitions ${ }^{208}$. That same year, a new design for the mausoleum was presented, which was created at

203 Kaczanowski, Zagłada Michniowa, p. 178.

204 Kołomańska, Michniów, p. 19.

205 Kaczanowski, Zagłada Michniowa, p. 179.

206 Kaczanowski, Zagłada Michniowa, pp. 182-183.

207 "Martyrologia Wsi Polskich", http://www.martyrologiawsipolskich.pl/mwp/mauzoleumw-michniowie/2547,RYS-HISTORYCZNY-MAUZOLEUM-MARTYROLOGII-WSIPOLSKICH-W-MICHNIOWIE.html (last accessed: 19 Feb. 2018).

208 Kołomańska, Michniów, pp. 19-20. 
the Nizio International Design architecture studios. The investment was subsidized by the Ministry of Culture and National Heritage and the local authorities of the Holy Cross Voivoideship ${ }^{209}$ which were responsible for the Kielce District Countryside Museum ${ }^{210}$. In April 2010, in the presence of Waldemar Pawlak, who was then both deputy prime minister and chairman of the Polish People's Party, the Kielce District Countryside Museum signed an agreement with the Ministry of Culture and National Heritage, which set in motion the first stage of the Mausoleum's construction ${ }^{211}$. However, funding shortages have meant that, as things stand, the Mausoleum's modernization is yet to be completed - all that has been erected is a bare building.

The museum is supposed to resemble a cottage, illuminated at night by lights reminiscent of Michniów's burning buildings (Fig. 2.3; see also Fig. 2.1 and Fig. 2.2). The segments at the rear of the building are lower and are supposed to give the impression that they are crumbling and plunging into the wood behind the building, which is meant to symbolize the physical annihilation of many villages during the war. The exposition at the museum will be divided into seven modules: Michniów. A Kielce Village; The Village's Annihilation; The Village's Exploitation, 1939-1945; The Borderlands during the Second Polish Republic; The Village Fights Back; Crimes Not Falling under Any Statute of Limitations and Helping the Jews. A detailed description of the ground covered by each module can be found on a website devoted to the martyrology of Polish villages. This was launched in September 2011 by the Kielce District Countryside Museum. It contains information on various villages' fates during the Second World War and information on the construction of and conception behind the Michniów Mausoleum of the Martyrdom of Polish Villages ${ }^{212}$. The descriptions of the

209 "Obchody 70. rocznicy pacyfikacji Michniowa", 12 July 2013, Polonia Christiana, http://www.pch24.pl/obchody-70--rocznicy-pacyfikacji-michniowa,16267,i.html (last accessed: 19 Feb. 2018).

210 Since 2008, the Kielce Village Museum has been jointly organized by the Holy Cross Voivodeship and Minister of Agriculture and Rural Development. http://bip.sejmik.kielce.pl/78-wykaz-wojewodzkich-samorzadowych-jednostekorganizacyjnych.html.

211 "Uroczyste podpisanie umowy na modernizację Mauzoleum Martyrologii Wsi Polskich", Muzeum Wsi Kieleckiej, http://mwk.com.pl/pl/sg/nasze_obiekty/mauzoleum_ martyrologii_wsi_polskich_w_michniowie/uroczyste_podpisanie_umowy_na_ modernizacje_mauzoleum_martyrologii_wsi_polskich/(last accessed: 19 Feb. 2018).

212 Otwarcie wystawy „Michniów 1943. “Zbrodnia bez przedawnienia” oraz uruchomienie portalu poświęconego martyrologii wsi polskich - Kielce, 29 września 2011”, Instytut Pamięci Narodowej, https://ipn.gov.pl/pl/aktualnosci/ 
individual modules were prepared by representatives of various institutions involved in the commemoration of events that took place during the Second World War ${ }^{213}$. The following words were spoken by John Paul II served as a motto for the website and the mausoleum as a whole: "Świat powinien wiedzieć, ile nas, Polaków kosztowało prawo do swojego miejsca na ziemi” (The world

7067, Otwarcie-wystawy-Michniow-1943-Zbrodnia-bez-przedawnienia-orazuruchomienie-port.html (last accessed: 19 Feb. 2018).

213 The first module that visitors to the Mausoleum will encounter will be devoted to the local history of Michniów as well as other villages in the Kielce region. The Michniów Pacification has been described by Ewa Kołomańska, a member of the academic staff at the Kielce District Countryside Museum responsible for researching this topic. One of her colleagues at the institution, Katarzyna Jedynak, has written an outline of the history of the Kielce Region during the war. Professor Jerzy Gapys from the Institute of History at the local academic center - the Jan Kochanowski Museum in Kielce - has prepared a description of the annihilation of Polish villages during the war and collected data on those who were murdered. Finally, an outline of the issue of the exploitation of Polish villages in 1939-45 has been prepared by the chairman of the Foundation for Polish-German Reconciliation, Dariusz Pawłoś. The structure of the Borderlands during the Second Polish Republic module reflects the manner in which the Polish lands were perceived in the period after First World War rather than contemporary perceptions. In the early 1920s, the term "Borderlands" was used to describe land adjacent to both the western and eastern borders of the Polish state, but since the end of the two world wars, the term has been used exclusively in relation to the land in the eastern part of Poland during the interwar period. However, the website employs the manner of defining Polish territory in use before the Second World War. A description of the situation in the Western Borderlands has been prepared by Piotr Szubarczyk from the Gdańsk branch of the Institute of National Remembrance. The fate of the Eastern Borderlands has been described by two people: the history of the north-eastern part by Kazimierz Krajewski from the Warsaw branch of the Institute of National Remembrance and the south-eastern part by Ewa Siemaszko, a social activist striving to preserve the memory of the Volhynia genocide, an event that she is conducting research into. A text presenting the history of the participation of peasants in the struggle against the occupying force (part of the The Village Fights Back module) has been prepared by Jerzy Gmitruk, director of the Museum of the History of the Polish Peasant Movement in Warsaw. The material covered in the Crimes Not Falling under Any Statute of Limitation module has been presented in a text titled The Legal Aspects of Prosecuting the Perpetrators of Crimes Inflicted on the Inhabitants of Polish Villages during the Second World War, which was written by Antoni Kura from the General Commission for the Prosecution of Crimes against the Polish Nation. The contents of the final module, Helping the Jews, have been presented by Mateusz Szpytma - former director of the Ulma Family Museum of Poles Saving Jews during World War II in Markowa and, since 2016, vice-chairman of the Institute of National Remembrance. 
should know how much our right to our place on earth has cost us Poles). They will be displayed on the wall of a chapel housed within the Mausoleum.

On 16 March 2009, another attempt was made to identify and bring to justice the perpetrators of the Michniów Pacification. That day's investigation into the case was undertaken by the prosecutor Krzysztof Falkiewicz from the District Commission for the Prosecution of Crimes against the Polish Nation in Kraków. However, the case was dismissed on 27 May 2010 due to it being impossible to discover who the perpetrators were by identifying the names of those who had participated in the pacification ${ }^{214}$. Although all attempts to bring the perpetrators to justice have ended in failure, the remembrance activities have proved to be a success (particularly at a local level). The production of material and nonmaterial memory infrastructure centered around Michniów has continued over the years, preserving the memory of wartime events at a local level and serving as a point of departure for attempts currently being made to spread information across the whole of Poland about the contribution the villagers made to the war effort.

\section{The Memory of a Rural Community and Historical Policy}

The story of the Michniów Pacification has a long tradition, stretching from the first songs, written a few days after events, to the books and articles taking the form of museological presentations. The narrative of these events is expansive and rich in detail. It was created and propagated through both traditional means suited to a vernacular rural community and modern methods. Traditional methods of transmitting this narrative primarily related to Michniów's community of inhabitants. These comprised stories transmitted orally within the family and local community and religious acts of commemoration that took place by the collective grave in the village center (not only anniversary masses, but also numerous services held on All Souls' Day and throughout the year). The methods that can be characterized as "modern" not only involve the conducting of historical research and presentation of the results of this research in book and article form, but also the writing of books with more of a popularizing function and the creation of successive museum exhibitions. These two kinds of activity, which both allude to the past, are intertwined. The stories of witnesses are used in books and at the museum. The content of these is familiar to Michniów's

214 Domański, I nie widziałem ich więcej, pp. 35-36. 
inhabitants but can also be learned via direct contact (by viewing exhibitions or reading books) or through contact mediated by anniversary ceremonies at which the course of events is remembered, articles in the local press or television reports and the local history presented to schoolchildren.

\section{Controversies Relating to Narratives of Wartime Events}

There is significant overlap between the stories transmitted orally by eyewitnesses to wartime events or members of their families and the narratives presented in books or at the museum. During the interviews, it was only possible to find two places in these stories where the facts diverged. However, these inconsistencies are very important for the people that point them out. One of these inconsistencies relates to the site of the reprisal attack carried out on the German train by the Ponury detachment: "At night they arrived, the train came with German soldiers from the front, the wounded, just here in the corner (...) [see] how the rails run, but they write that it was near Łączna, don't believe a word (...) yes, this is a bit of a fib, they're not telling the truth, because they're saying behind Łączna, but this is not behind Łączna, the last house has finished, the railroad goes there and the rails and train passed by. Here, near Rutka" (F, ca. 90 years old, Michniów, July 2015). In another interview, another frequently repeated narrative motif (stating that the whole of Michniów burned down but for a single stone barn) is dismissed: "the whole of Michniów was burned down during the pacification (...) that's what they write, about the stone barn belonging to the Malinowskis. But there was another stone barn belonging to the Dulęba's and here is another stone barn (...) In other words, three barns survived, because they were made of stone" (F \& M, group interview, ca. 70 years old, Michniów, July 2015).

In the stories told by the people mentioned above, the overall narrative of German bestiality, the village's destruction, and the murder of its inhabitants are never called into question. The desire to point out these inconsistencies to people who come from outside the locality, and even the region, may be indicative of two phenomena. Firstly, it provides clear evidence of the fact that the inhabitants are familiar with the official historical narratives of the Michniów Pacification, including the details. Secondly, the desire to point out that professionals (historians, journalists, writers) are not as capable as local people of faithfully rendering local history shows who this history belongs to, whose lives and biographies it forms part of and for whom it is external history, something that is important and moving, but not directly related to a specific person's life. The villagers' desire to point out inconsistencies also shows the close relationship between memories and specific points in space. It is such places and buildings 
or objects that together constitute an anchor of memory that evokes images of events from the past and ensures they maintain their vitality. This is also why they are of greatest importance to the oldest generation - the eyewitnesses. The narratives that reach the next generations are more generalized, and the sites and events they contain acquire symbolic characteristics rather than serving as genuine anchors of memory. Consequently, the image of Michniów burned to the ground with only a single barn surviving the conflagration is more important to them than counting exactly how many such barns survived. However, for the oldest generation, such concrete details are quite simply their lives. For them, the pacification is, by its very nature, a real biographical event rather than a symbol uniting the generations (because the following generations can only experience the pacification through the mediation of narratives and then construct this experience using elements that have acquired symbolic significance).

The narratives of historians and popularizers of knowledge about the past also do not contain the kind of unverifiable elements that are the focus of speculation. Nonetheless, such elements are circulated by the local community. One of these elements was referenced by one of the interviewed people from the oldest generation who was a child during the pacification, but constantly heard stories about it from within his family and among the neighbors:

The youngest bandit according to these German files, the youngest bandit from Michniów was nine years old. Though I should add, since that is the official version and I'll tell the unofficial one, that, probably, the youngest bandit in Michniów - it's not known whether it was a girl or boy - had only been born an hour, maybe half an hour, before dying. There is... there are signs, recollections that Mrs. Miasek was at an advanced stage of pregnancy and had given birth. Anyway, she died and the child as well. Also, that is something that would be spoken of unofficially. But officially, it is that Stefanek Dąbrowa who is regarded as the youngest Michniów bandit. (M, ca. 70 years old, Michniów, July 2015)

The statements cited above do not, however, call into question narratives that had been established for years. The sequence of events during the pacification, the villagers' fate, and the subsequent actions at the same site were reconstructed in some detail on the basis of eyewitness accounts and documents. However, the situation is somewhat different when it comes to the interpretation of the actions taken by the partisan detachment commanded by Ponury. Undoubtedly, the Germans took action for the first time in Michniów on 12th July 1943, because they wished to punish those aiding the partisans, whereas the pacification on the following day was a response to the retaliatory action Ponury carried out on the night of 12th and 13th July. It was the Germans who perpetrated these actions on both days and it is they who all the narratives present 
as criminals. However, the Michniów villagers believe that problems of interpretation arise when they wish to respond to the question of why their village fell victim to such a pacification. Within the context of the action taken on 12th July, it is the traitor going by the pseudonym of Motor who is most often cited as betraying local partisan detachments, though it is also said that there could have been more such traitors. Traitors are also judged in purely negative terms in both the official narratives and the stories of local inhabitants. However, the situation is not so clear-cut when it comes to the second pacification on July 13th. On many occasions during the interviews, references were made to grievances that people harbored toward the partisans. This was mentioned not only by representatives of the oldest generation, but also members of the succeeding generations, explaining why this motif appeared in conversations and local stories: "All I know is it wasn't just her, many held a real grudge toward the partisans, because they knew. They didn't warn [us]. Many fewer could've died if everyone could've somehow got out. I really don't know what the Germans would [have done] then if they'd been driven to that level of fury..." (F, ca. 65 years old, Michniów, July 2015). A representative of the oldest generation working at the House of Remembrance stated:

One matter relating to Michniów is yet to be explained to this day. Why did Ponury not come when he should have done? His headquarters, his eyrie [as they called it] was here, people said (...) so he didn't come to this eyrie to help. Questions therefore remain that in fact are not being met with any public response. One can only hazard a guess or make conjectures. Anyway, it must be said that the village, the people held a grievance against him for that. But not any longer, because there are no more survivors. Yet I remember, as I was saying, those years, the early fifties, when they were openly expressing their doubts very plainly here. For it is one thing when a soldier holding a rifle dies, but completely different when the same happens to a child, a woman or some other innocent. They have no way of defending themselves, not the slightest chance. (M, ca. 70 years old, Michniów, July 2015)

It is only in interviews that the legitimacy of the partisan's actions was called into question; there is no mention of this either in the publications describing the pacification or the narrative of the museum exhibition at the House of Remembrance. Consequently, even when the museum staff talk about the controversies bound up with Ponury's decisions, none of this is reflected in how they convey memory of the pacification during their work. It can be concluded from this that a heroic, martyrological narrative requires clearly delineated roles - a division into the good and the evil. There is no place in such a narrative for questioning the correctness of decisions made by those ascribed the role of heroes. 
Another element impeding a clear division between the good and evil is the story of a "good German" who saved one of the children. It only appears in one interview and is not described in books about the pacification. One of the oldest women interviewed described this incident as follows:

The bullet passed close to his heart and from there, through his back, he was bleeding heavily and they set a fire, poured some fuel over it and moved on. He was moaning terribly. And a single serviceman approached. Whether it was some Pole taken [by the Germans], or a German or half German, that I don't know, because they themselves didn't know who was who because it was the middle of harvesttime. And he had heard this moaning when they set the fire and broke off [from the others] and he lifted his head and says: 'Anyone who is alive speak up now. And yes, that child was moaning terribly, he was bleeding (...) And this German came in and carried him out - most of the house had gone up in smoke - and [laid him down] in a rye field. And he brought him water and bandages there, bandaged him up and sat with him there until everything calmed down. (F, ca. 90 years old, Michniów, July 2015)

This behavior was so out of tune with the predominant image of German bestiality that the interviewee even wondered whether the man was definitely German or whether he had any Polish roots. This clearly shows that even stories presented as a faithful reflection of events are mediated by a general interpretative framework that enables a cohesive picture of wartime events to be maintained.

From the perspective of Poland's national history, the events in Michniów are another example of German terror - the story of the pacification of a village aiding partisans fighting an occupying force. However, at a local level, the question arises among the families of those who were murdered of whether it could have been possible to avoid such a large number of victims and whether refraining from inflicting such reprisals could have preserved their loved ones' lives. The former director of the House of Remembrance clearly indicates that this "brooding and doubting" type of memory of the causes of the pacification has receded into the past as the people who directly witnessed these events have died. The generations that followed, even if they know that some assessments of the partisans' actions raised doubts in the past, now accept a more generalized narrative that stops short of questioning the partisans' actions. As time passed, local inhabitants also developed a manner of presenting their doubts that enabled them to express these while refraining from any form of explicit judgment. This type of argumentation appears in the following statement given by the former director, who first criticizes Ponury's military prowess, then passes up the opportunity to assess the situation as a whole:

So there needs to be some conception of what is being done, how an operation should be led, how the detachment under one's command should be kept safe. All the more so 
since, as an officer [with experience gained] before the war, he should know a little about the tactics here. Yes, in my view... But all these critical comments are mine. I wanted to stress that they are my critical comments. It is easy for me to speak about certain issues retrospectively, but then maybe I don't know all the motives and I'm judging how it is, how I see this today. (M, ca. 70 years old, Michniów, July 2015)

It is not, therefore, the case that this assessment is positive. What this statement really shows is how impossible it is to make a positive assessment while defending one's right to harbor doubts. Interestingly, the impression may be gained that, rather than expressing the isolated stance of one person, this statement represents a locally adopted type of argumentation, because a similar line of reasoning also appears in the following statement by a representative of the middle generation working in a neighboring village:

What is more, like every thinking person, [I wonder] why they did that. But how can we think about this, we didn't experience these times, for that I'm thankful, yet I'm curious - what would we have done? (...) Maybe if they hadn't blown up that train, that massacre never would've happened. Yes, but why did the Germans shoot these men when they were only assisting the partisans? Yes, that's another way of looking at it. Also, all the time I'm repeating - we didn't live through those times, there's no way of knowing what we would've done in their place. (...) That is, yes, that's how the history's been recorded, so let's leave it at that. All credit to them for fighting as best they could. That's all they could do, it can't be helped that it happened that... there was such a reprisal. Yes, but they probably meant well, at least that's what I assume. (M, ca. 75 years old, Michniów, July 2015)

The national and local narratives converge on one point - no one questions the partisans' good and noble intentions. The expressions of resentment against them vanished along with the oldest generation, yet the younger generations are sometimes still aware that such controversies arose in the past. "Because there's no longer any resentment in the village, yet the memory lives on here." (M, ca. 70 years old, Michniów, July 2015), as the former director of the House of Remembrance claimed.

The fact that these resentments are still remembered has the strong potential to express the specific nature of the local experience - the villagers effectively become the focus of operations being carried out by the underground state rather than passive "extras" playing an auxiliary role or people who became involved in actions planned by others, in this case, Warsaw-based commanders. However, this might also turn them into double victims, firstly, of the German terror and secondly, of ill-considered decisions taken by the Polish partisan commanders. In the meantime, if the Polish national narrative of the struggle and martyrology of the villages is accepted, they become heroes - the people who fought with the 
occupying forces and paid with their lives for actions furthering the liberation of the Motherland. This is, in fact, the narrative being adopted by successive generations discovering about wartime events from books, textbooks, museums, and the programmed events of anniversary ceremonies. For them, local history has become yet another chapter in a general narrative relating the fate of the whole country and this chapter's specific characteristics arose from the escalation in cruelty apparent in the occupying forces' actions rather than a subversive narrative about poorly planned partisan actions. Another element of the local context is also important. According to studies carried out by historians, around 40 men from Michniów could have served in the Ponury detachment ${ }^{215}$. Accepting the narrative relating the partisans' errors would, therefore, be tantamount to attributing some blame to the family members of those who died. Thus, all the doubts under discussion exclusively relate to the conduct of Ponury, who was sent by the Warsaw command and did not have any previous ties with Michniów or the Holy Cross region.

Another narrative strand useful for interpreting wartime events reflects the diverse nature of the partisan forces operating in the region. In the area around Michniów, most people were recruited by Home Army or Gwardia Ludowa units, but the Chłopskie Bataliony (Peasant Battalions) also operated around the Kielce region as a whole. This diversity reflected the continued wartime presence of deep political divisions dating from the interwar period. After the war, during the Polish People's Republic, the Home Army was censured, but when the political transformation began in Poland in 1989, the situation reversed again. AK membership was now presented as a reason for pride, while the actions of the Gwardia Ludowa and Chłopskie Bataliony were perceived as duplicitous (both because they were "communist" and because they opposed some of the AK operations, especially those in rural areas that provoked reprisals from the Germans) and began to vanish from social memory. Nonetheless, the debate on the role played in various operations by the various formations continues to be emotive and important in social terms ${ }^{216}$. The House of Remembrance's former director, who has declared his strong opposition to the radical change in memory policy after 1989, perceives this issue as follows:

What did the average boy here in Michniów know about the Home Army back then? Well, maybe the AK command knew something, maybe so, but he was a partisan and he didn't care! I mentioned the Gwardia Ludowa, but the poor boy also didn't know that the

215 Domański, I nie widziałem ich więcej, p. 205; Kaczanowski, Zagłada Michniowa, p. 31. 216 See Karkowska, "Międzypokoleniowe transmisje...” 
guardsman over there is some sort of... what's he doing here?! Here he was in Ponury's detachment and over there was Sashka, they had escaped from Święty Krzyż $\dot{z}^{217}$. After all, there were also Russians there... And that's just the way it was, these people didn't realize or attach any importance to where they were. Basically, he wanted to serve with the partisans, wanted to fight, signed up [without considering the further consequences of] being in a particular resistance movement and what kind of movement that was. Whichever was closest to him. So that's how it was. And dividing people in such a situation into good and evil - "you were right, and you were wrong" - makes no sense whatsoever, both then and now. (M, ca. 70 years old, Michniów, July 2015)

He was the only interviewee to refer to this issue. The narratives of the others mainly focused exclusively on the Home Army because this was where the people of Michniów most often ended up. However, this type of justification of the wartime action taken by a village (i.e., referring to the lack of awareness, among peasants, of the political context) also appears in statements given in other places. It can also be interpreted as an attempt to show the importance of the wartime efforts of specific villages whatever the short-term political policies of the central government may be. This stance is also consistent, as it turns out, with that of the Polish People's Party. Peasants are presented as the social class that was most numerous during the war yet marginalized by contemporary history policy. Implementing the idea to include this class in the narratives flowing from the center may, therefore, entail a need to stress its relationship with the Home Army (whose history has been turned into one of the pillars of national identity constructed since the 1990s) or highlight the diverse contribution that villagers made to the war effort.

\section{Controversies Surrounding Commemoration of the Pacification}

The controversies associated with the reconstruction and interpretation of wartime events are slowly disappearing as one generation succeeds another, and these do not seem to provoke strong emotions among the local community anymore (or at least they are not mentioned in conversation with people outside the community). This is not the case, however, when it comes to the controversies provoked by the contemporary methods of commemorating the village's pacification, in particular, the construction of the modern Mausoleum of the Martyrdom of Polish Villages in Michniów. These disputes are centered around what form the commemoration of the village's fate should take. They lay bare

217 Lit. "Holy Cross", an internment camp in the Holy Cross Mountains where the Nazis held Soviet prisoners-of-war during the Second World War. 
how deep the differences are between national and local conceptions of what "commemorating" actually means. One point of disagreement relates to the conceptions of the religious aspect of commemoration. Another relates to the manner in which esthetic forms should be rendered - the museum's modern geometric form is not to everyone's liking. The third difference is engendered in tension between the desire of central memory actors (ministry staff, museum workers, historians, and architects) to present a generalized (in terms of both content and form) picture of Polish villages' wartime history and an alternative desire to portray the local tragedy.

The first difference is exemplified by disputes centered around St Margaret's the chapel erected beside the collective grave in the 1950s. The chapel serves as a venue for occasional religious ceremonies and, during the summertime, Holy Masses on Sundays. It is also a place where Michniów villagers bid farewell to the deceased before their coffins are taken to the ceremony. Nonetheless, there was no place for the chapel in the first mausoleum design. As one museum employee recalls, there were even plans for it to be demolished, although several decorative elements from its interior would have been incorporated into the first exhibition room at the museum:

We wanted to move it, we wanted to open this building with it. We wanted to move it, but we wanted to completely dismantle it and integrate it as an element of that building, as that first building is also ultimately a chapel. But the inhabitants didn't agree and we respected that and renovated it (...) somewhere this chapel will now be visually integrated with this new building (...) there were various proposals. Either it should be moved in its entirety into that forest of crosses that was to be there. Or it should just be dismantled and then elements of an altar or decorative elements could be created from the chapel. "No, because it's ours, we built it, through our toil, as it were, so it's hard for us to get rid of it, hard to dispose of what we've made." (F, ca. 45 years old, Michniów, July 2015)

This proposal clearly met with the villagers' fierce opposition. As one of them recalls: "As soon as we realized the chapel wasn't in the design we wrote to the relevant institutions to request that the chapel be saved" (F \& M, group interview, ca. 70 years old, Michniów, July 2015). The museum employee quoted above was most keen to emphasize the chapel's social significance, pointing out that it was difficult for people to part with something that they had made with their own hands. However, the local priest's interpretation expands on the sources of this protest:

It was also erected by the people, and not in the most favorable of circumstances, so there were differing opinions as to whether [the authorities] should leave [the chapel as it was] when this [Mausoleum] project was created, whether the two should co-exist, but 
the people stood firm and made it clear that this chapel should stay and I think it's good it did. This was built after the war, this chapel, but it was also a place thanks to which this memory, you know, the Eucharist was held, due to its presence, people come to say the rosary, for the May Day service, there's always this cross, this grave, which is there, it appeals to them. They are at this place and it creates this atmosphere of some kind of deeper religious experience. (M, ca. 55 years old, Michniów, July 2015)

Remembering the dead, rather than being perceived as a social duty, is mainly viewed as a religious duty, and the local community believes that religious rites are the best way of honoring the memory of their dead. This does not preclude the existence of other, secular forms of commemoration, but these can never replace the religious ones. The priest is not the only person to sense this. Such a perception of the importance of religious rites also occurs in the statements of other people who were interviewed - Michniów's inhabitants. For these villagers, especially those from the oldest generation, religious rites are a permanent feature of life, a standard practice alluding to a particular experience that cannot be replaced by anything else $\mathrm{e}^{218}$. The creators of the current design for the Mausoleum thought about religion in an areligious manner, that is, in terms of a general practice conducive to reflecting on human fate. This mode of thinking was expressed in the design for the creation (in the first room the visitor enters) of a Place of Silence - The Emblem of a Cottage Home. It was to be a place of reverie and reflection where services and prayers of various kinds could be held. It was in this place that elements of the dismantled St Margaret's Chapel where to be installed. However, the villagers interpreted this project as an attempt to divest them of a sacred space and propose that it be exchanged for a place that, even if it was going to be associated with religious practices, would never be sacred for them. They define the sacred, by force of necessity, in purely Catholic terms. One villager, on being asked whether the chapel by the mausoleum's entrance would be Catholic, responded as follows:

Well, how can it be Catholic when there's no cross on top?! How can it be? This is a chapel here. That chapel there can be for everyone. This is what I think. I think that if there was a cross outside, then the whole building would be, as they say, Catholic. Since they did what they did, they were trying so long to get this [local] chapel demolished and they said, 'you'll have another chapel [in the Mausoleum]', and that chapel is for everyone. Because a Protestant will come, a Jewish... - what do they call their priests? and they can celebrate their own Mass there! And no one will come here [to the local

218 Kamila Baraniecka-Olszewska, The Crucified: Contemporary Passion Plays in Poland. Berlin/ Boston: De Gruyter, 2017, pp. 53-55. 
chapel], because there's only a Catholic priest. (F \& M, group interview, ca. 70 years old, Michniów, July 2015)

Clearly, the Mausoleum's creators' proposal that the villagers be given a large chapel in a new building in exchange for their permission for the old chapel to be demolished was interpreted as an attempt to divest the village of a sacred place. A Catholic chapel built by the inhabitants themselves would have been exchanged for an ecumenical space within the concrete walls of the mausoleum building. However, the close bond the villagers feel with the Catholic religion ensures that Michniów's place of prayer will continue to belong to the local community. In the conversation extract cited above, the cross is not just perceived as a sign for the villagers' "own". It is primarily viewed as a sign for outsiders visiting the place in question. This transforms it into a sacred Catholic space that will not be disturbed by "outsider" priests.

The sacred space associated with the commemoration of the past not only comprises the chapel, but also the collective grave. The museum employee stressed that the villagers never refer to it as a monument, unlike outsiders visiting Michniów, who do this very often. This employee compared the situation in Michniów with that in a neighboring village that had also experienced a pacification, but whose victims had been buried in a cemetery:

This situation is different, for example, when victims, for example, of a pacification are buried in the place where that pacification took place, only buried in a cemetery. Things are a bit different then. (...) People believe that this place is, for sure, marked by history, but there's no longer such a sacred dimension. Because these victims were moved to a consecrated place, buried in accordance, usually, with the Christian, Roman Catholic rites, this burial was held and these victims were, as it were, there and this memory is concentrated around this place, this grave there, in the cemetery (...) for the people, for example, it is important that their loved ones have been laid to rest in this grave. There's a cemetery of sorts, there's contact with those who died. (F, ca. 45 years old, Michniów, July 2015)

The fact that victims of the pacification are buried in the village center in accordance with suitable religious rites makes this a sacred place. In such a case, the rural community's memory is focused around this place due to the religious rites bound to the place of burial rather than any secular (state or school) ceremonies that may take place there. In the view of the museum employee cited above, if the victims' remains had been transferred to a cemetery, it is on there that any commemorative religious rites would be focused. Reflecting on the obligations arising from a religion and commemorating the deceased are tightly interwoven phenomena. Religion provides remembrance with a form and language, explicating it within a broad metaphysical context. Since there are no other methods 
of commemoration functioning locally, there is a strong tendency to appeal to religion when remembering the dead. However, the Mausoleum's creators perceived religion as a set of symbols that could be placed anywhere and within any context. This approach was completely incompatible with the local perception of religiosity, which, first of all, was closely bound up with specific places marked and defined as sacred and secondly, relates to a particular faith with its own laws and rites, rather than religion viewed in general terms.

The second type of difference exhibiting the disparity between local and general visions of remembrance (national or even referencing global trends) emerged from a series of disputes over the spatial conception for the Mausoleum. The architect's vision greatly diverged from the expectations of both the local community and those of the museum staff. One museum employee recalled the first stages of their cooperation as follows: "Well, when Mr. Nizio came to us (...) he said that everything would have to be demolished. (...) So our first meeting was, let's say, heated. All well and good, but apart from this architecture, it would need to have some form of functionality. Only then was any thought given to... and he restructured it a great deal in terms of its functionality, ornamental features and the integration of the cross-monuments into the building itself" (F, ca. 45 years old, Michniów, July 2015).

The notion of destroying all the memory markers erected earlier was unacceptable to people working and living in Michniów. However, it is intriguing that such a notion could have surfaced at all. Maybe this attests to the existence of a general pattern of thinking about the composition of buildings of this type in which there is no place for local diversification of symbols, forms and methods of commemoration. Form imposed in top-down fashion (which is presented as corresponding to pre-approved and supposedly binding esthetic concepts) precludes the possibility of dialogue with the local community on whose land the building is meant to appear. If a compromise has now been reached, this is due to the local community expressing their opposition rather than the authorities taking into account the community's concepts and sensibilities when the design for the national site of memory was still at the planning stage.

Even when the local community manages to preserve memory markers that were created earlier, these markers are made to conform to a form imposed from the outside. This is what is meant to happen with The Forest of Crosses, which has long been a recognizable site associated with Michniów. As the local priest said:

Here there was a sort of cemetery, a kind of Holy Cross Golgotha, such a Holy Cross Grabarka $^{219}$, for it was a forest of crosses. (...) all of them are to be preserved... only in

219 Grabarka - a holy mountain and monastery complex in eastern Poland, the most 
military-style rows in a military cemetery (...) [The crosses will be lined up] in even rows, [visitors] will enter [the cemetery] from the back and leave it from the various sectors, and [the crosses] will be located there, but everything will also be in parallel lines. They were intriguingly diverse as they were, don't you think? Some were metal, some were wooden, some were carved and others not, smaller, larger, as one entered it, it was just like the grounds of a typical... typical cemetery. (M, ca. 55 years old, Michniów, July 2015)

The difference between a cemetery functioning within a specific vernacular community and a military cemetery lies in the manner in which space is organized and comes into being. Military cemeteries are often created as part of a single cohesive project. The deceased are buried at the same time, the form of remembrance is uniform and space is organized in such a manner as to impart a sense of military discipline (additionally associated with a soldier carrying out combat duties). Civilian cemeteries steadily expand with the passing of time. The deceased are buried at different times by different people. The esthetic forms of graves alter over time. Within socially and religiously accepted boundaries, there is room for the expression of human diversity - manifested in esthetic tastes, social status, traditions, and identities. It was this that was most apparent to the priest, as he observed over the years how delegations from various pacified villages erected their crosses commemorating the fates of their own communities. He perceived this diversity as a positive value. It was something natural to him, something that gave a traditional civilian cemetery its unique appearance. However, erecting identical crosses in even rows is an act of commemoration that the priest is also willing to accept. Nevertheless, although such an approach fulfills its own commemorative functions and alludes to a religious symbol, it eliminates local diversity by disregarding the unique identity of the communities being commemorated. The villagers are prepared to accept such a form, not because it appeals to them, but because it is officially approved of. The same applies to the entire Mausoleum building. One of the oldest interviewed people commented on it as follows: "It's just a lump of concrete there. (...) I don't know how it can be, in this day and age, that there are also those situations there in Ukraine; we are close, it could be used as a bunker (laughs) (...) Everyone who passes through here... what I'm saying is that no one's liked it yet. What I'm saying is - oh well, they've made it, they've made it like that, it's no concern of ours..." (F \& M, group interview, ca. 70 years old, Michniów, July 2015).

important center of cult worship for followers of the Orthodox faith in Poland. A multitude of votive crosses can be found there, brought by pilgrims from the nineteenth century to the present day. 
Although the Mausoleum's form is modern and has not only won the recognition of central government but also international acclaim, ${ }^{220}$ the villagers, especially the most elderly ones, distance themselves from the building, openly declaring their feelings and poking fun at the whole project. The building is not only alienated spatially (as a large concrete block in the middle of a small village) but also socially. "It's no concern of ours," claimed the villager cited above, yet the Mausoleum is supposed to present his own history - the history of Michniów's inhabitants. There is no overlap between the vernacular ways of conceiving the commemoration of victims of the war and the forms being implemented from the outside. They function separately. The villagers have reconciled themselves to this fact and are only really interested in preserving that space they perceive as sacred, space where genuine remembrance of the victims takes place.

Conflicting viewpoints also appear in discussions about how the Mausoleum should be managed and how it should function. These do not really affect the inhabitants of Michniów, but they are being encountered by the museum staff currently attempting to create a concept for the whole exhibition. They also perceive the Mausoleum as a kind of sacred space. Sacredness, thus conceived, rather than being closely connected to religion, has more in common with culturally reinforced mechanisms for showing respect to the dead. This can be contrasted with the perception, observed by a museum employee among central government officials, of museums as cultural-entertainment-economic enterprises:

when writing up grant applications to be sent to the Ministry of Culture, at some point I encountered the strange question of why nothing like the digging up of a dinosaur is offered for younger children and I was extremely surprised that someone could write me such a question, but I can say that I won't be doing any - pardon the expression - exhumations for younger children... I don't know, maybe there really are such guidelines [stating] that everything must be offered, but I believe we don't need to have everything everywhere. Or [as for the suggestion that] we have too monochrome an offer for visitors because everything is very serious, well, it's hard to organize a disco at a cemetery. In fact, we also need to approach this place as a kind of sanctuary, where we teach the history, show certain events and provoke reflection. (...) I won't be telling any jokes or saying anything witty by the grave of the murder victims, because this is not the place for that. (F, ca. 45 years old, Michniów, July 2015)

The appearance of such ideas at the central governmental level may attest to the emergence of a conceptualization of the museum as an institution fulfilling

220 In 2011, the design for the Mausoleum won a prize at the International Property Awards in the Highly Commended Public Service Architecture category Retrived from: https://propertyawards.net/europe-2011/ (last accessed: 01 Mar. 2018). 
various functions. As the interviewee cited above indicates, giving due consideration to a museum institution's specific features is of paramount importance. The commemoration of death, particularly death inflicted suddenly and on a mass scale, operates within social norms that sacralize the sites associated with a specific space even if the commemorative practices themselves are not of a religious nature. This sacralization need not allude to a supernatural reality, but it still transforms the space in question into a special place bound by behavioral norms that differ from those adopted outside it. In this sense, the Mausoleum may be described as a sanctuary.

Allusions to the sacred appear in every kind of commemorative practice occurring in Michniów. Apart from the collective grave, St Margaret's chapel, the newly constructed Mausoleum and The Forest of Crosses, a central place in the village is also occupied by the Pieta Michniowska memorial. The Pieta is a culturally well-established and widely recognizable symbol of the suffering of a mother faced with the death of her son. Any differences appearing in the interpretation of the Pieta Michniowska relate to the extent to which this image is open to generalization. The museum staff primarily perceive it as a universal symbol. According to the a website aimed at tourists: "Its universal message, redolent of the sacrifice and suffering of innocent victims, caused it to swiftly become a symbol of Michniów's Mausoleum"221. One of the museum employees explored its message in more depth, claiming that its primary allusion is to the fate of women:

The Pieta also alludes to that martyrdom, those mothers whose sons were murdered in the pacifications, murdered in partisan units, died as partisans, were murdered as Poles, so often it was basically the women who were left... the women remained, these were villages of widows, that's what they were called, that's how these settlements were created where these women had to fend for themselves for another four years of occupations. They found themselves in this reality [where they had to] work, [meet] all the German's demands and support themselves and their families and often they no longer had their cottages, because they had burned down. (F, ca. 45 years old, Michniów, July 2015)

The creator of the mother figure on the monument wanted it to display some regional elements, so she was dressed in a traditional Holy Cross apron. This information circulated among the villagers and was referred to in the interviews.

221 "Mauzoleum Martyrologii Wsi Polskich w Michniowie", Website Czas na wypoczynek. Retrived from: http://czasnawypoczynek.pl/Atrakcje,Michni\%C3\%B3w,C004988,Ma uzoleum+Martyrologii+Wsi+Polskich+w+Michniowie (last accessed: 2 Feb. 2018). 
However, one of these conversations contained an interpretation that made direct reference to historical events in Michniów:

As for the Pieta, it [relates to real events] here... She's called Materek ${ }^{222}$. (...) Materkowa survived, this son made it known to her that he had survived too, eight [children] were killed, she was wounded and her son, this son, was wounded. (...) This is that mother, Materkowa, with her son in her arms, [who's] dying. Because this was made as a remembrance, this is... Yes, this is a real person, this is a mother with this son in her arms who the German saved. As for that German, maybe he was a German, maybe a Pole, whatever the case... this is true. (F, ca. 90 years old, Michniów, July 2015)

This interpretation does not appear in any official sources, but the Materek family's story is evidently so touching that it has been associated with the scene depicted on the memorial. Consequently, the memorial not only has a universal dimension but can also be interpreted as being closely linked to local history. However, such diverse interpretations of the Pieta are not conflicting. The vernacular interpretations attempt to clarify the memorial's meaning without questioning its essence. What is being referred to here are not only the facts (symbolic ones, as its creator would wish, or literal ones - as is the understanding of one of the inhabitants), but also a form that is comprehensible to many groups of viewers. However, the situation is different when attempts are made to find alternative spatial locations for sacred objects or detach religious practices from their sociocultural context, as is the case with the Mausoleum project. In such a case, when interpretations relating to particular objects contradict each other, the local community objects to commemoration-related ideas coming from the center.

\section{Anniversary Ceremonies: Between Local and National Memory}

The dualism among memory practices is not only apparent in the material forms being created in Michniów, but also in the ceremonies accompanying successive anniversaries of the pacification. They always last two days, the first of which is of an official nature and the second, of a local, family nature ${ }^{223}$.

Since 12th and 13th July 1945 (regardless of what days of the week these dates fall on), anniversary ceremonies have been held by the grave of the pacification victims. The ceremonies on July 12th, the official day, are attended by the local (and sometimes central) authorities as well as representatives of various institutions, including schools. Nowadays, the ceremony on this date culminates

222 A family name. Materkowa is the feminine form.

223 See Karkowska, "Pamięć społeczności lokalnej..." 
in a Holy Mass, during which wreaths are laid on the grave by representatives from the Museum, the local and regional authorities and sometimes the government and PSL activists. Another component of the ceremonies is the delivery of speeches, and the whole event is accompanied by a commentary and background music: for many years, Ryszard Miernik's Song of Michniów has been performed on this day. The ceremonies are also accompanied by the color parties of various organizations (including veterans and the police, but also schools located in the neighboring village of Wzdół Rządowy, which is attended by children from Michniów). Sometimes there are other events accompanying the ceremonies, for example, on the seventieth anniversary of the pacification, a historical extravaganza titled In the Name of God, Honor and the Motherland was staged, which featured the participation of several historical reenactment groups ${ }^{224}$. Every year, the ceremonies on the 12th of July attract as many as several hundred people and receive coverage in the press and on TV, locally and sometimes nationally as well.

As previously mentioned, the ceremonies organized on 13th July are of a different nature. A Holy Mass is also held on this day, but it is more private in character and attracts much fewer people. Most of the attendees are villagers who survived the war and their families. There are no official speeches or laying of flowers on this day. The ceremonies are accompanied by music or artistic events, but they are more modest (for example, there may be performances by Suchedniów's local choir or local theater groups). The atmosphere of these ceremonies is also different. As one of the participants noted:

However, the second day, the thirteenth, is the kind of experience typical of this village's inhabitants. There are no big speeches or greetings there, all that is done on the first day, and that includes the laying of wreaths on the grave. But there is a Holy Mass, which is a little different from other such Masses, even those celebrated in the church, even the same place, [because] the grave itself urges all those who come to reflect deeply. All the more so, in the case of the people who still remember those who died... the thirteenth, they treat it as such, that's our family gathering. (F, ca. 45 years old, Michniów, July 2015)

An employee of the museum justifies the nature of the ceremonies of 13th July as follows: "because on the thirteenth mainly women and children died. As a matter of fact, it was on the thirteenth that the village ceased to exist" (F, ca. 45 years old, Michniów, July 2015).

224 "Obchody 70. rocznicy pacyfikacji Michniowa", Polonia Christiana, 12 July 2013, http://www.pch24.pl/obchody-70--rocznicy-pacyfikacji-michniowa,16267,i. html\#ixzz3t4AfEnve (last accessed: 9 Jan. 2018). 
The dualism of the village's remembrance practices is manifested in the division into official and private ceremonies: on the one hand, the Michniów Pacification is important for the vision of the past contained within state historical policy and on the other, it is important for memory within the local community. There is, therefore, no reason why the remembrance ceremonies and commemorative rituals themselves should provoke conflicts. They are divided as Jay Winter has written - firstly, into ceremonies and rituals that are meant to preserve and commemorate those motifs and visions of the past that accord with the interests of the wider community and construct identity at nation or state level while legitimizing the current political order and secondly, into ceremonies and rituals reliant on local circulation and the direct participation of members of a given community in practices of various kinds without the involvement of central institutions ${ }^{225}$. However, in Michniów's case, memory practices initiated by the central government and those established vernacular practices are not in conflict or competition with each other. They reflect the different needs that can be satisfied by memory practices. However, conflicts appear when central government decision-makers are unable to interpret all the needs and motivations inherent in vernacular memory practices - in Michniów's case, the need to remember the past is combined with religious motivations.

\section{The Transmission of Memory on a Local, National, and Global Level}

The local community in Michniów commemorated the murder victims in July 1943 and constantly return to these events either by practicing communal remembrance rituals or by mentioning them in private conversation. However, it is not the case that all those who witnessed the pacification wish to speak about it. The main obstacle is presented by the strong emotions they still feel: "But they didn't want to, maybe they didn't want to speak about it, because the experience was still very fresh to them, it really upset them, they wept. And now, well, we really regret that, as this... My dear mother told my girls a little [about it] but became emotional." (F \& M, group interview, ca. 70 years old, Michniów, July 2015)

225 Jay Winter, "Sites of Memory and the Shadow of War." In: Cultural Memory Studies: An International and Interdisciplinary Handbook, ed. A. Erll. Berlin: de Gruyter, 2008, p. 63. 
Another interviewee cited another reason for the lack of detailed information about the wartime period in her family: "We know very little about this subject now, because our parents didn't tell us so much, because they didn't want to talk about such matters, because they were afraid, because they were in the AK (...) And when they could've spoken about it, the system of government changed, they were already mixing things up, so now we can only keep guessing about what it was like. Or ask other people who still remember something about it" (M, ca. 75 years old, Michniów, July 2015).

In the interviews, statements of this type are in the minority, and the accounts collected in various publications show that witnesses did speak about the sequence of events during the pacifications and village's subsequent fate. However, they quite possibly did not speak in such detail about other aspects of the war period, for example, their involvement in partisan action. What is more, everyone was taking part in remembrance ceremonies, and schoolchildren were able to learn about the village's fate, during school trips, for example. On these, they had a chance to meet some of those who witnessed the wartime events and listen to their stories: "[When I was] at elementary school, grandma was still alive, sorry, I should say dad's mom, because mom's parents died early, so when I was on a such a trip with my class, we visited grandma, and grandma showed the boys and girls from my class what had happened" (F \& M, group interview, ca. 70 years old, Michniów, July 2015).

However, the following statement made by the local priest, a middle-aged man who comes from a nearby village called Strawczyn rather than Michniów itself, shows that information about the pacification was not taught at other schools in the region: "I also discovered about that Michniów history as a young lad when a group of villagers from Michniów visited, they recited various poems, you know the type - 'about the burned down village of Michniów', something like that... but at school, nobody explained anything to me about Michniów, even though we had history lessons [in a village] as nearby as Strawczyn, from where one sometimes traveled to Warsaw, [though] it was possible sometimes to travel up to Michniów. I don't know why so much was left unsaid" (M, ca. 55 years old, Michniów, July 2015). The priest only became acquainted with the details of the pacification when he became the local parish priest. Although he had a general grasp of what had happened during the pacification - he knew, for example, that Michniów had been burned down - he had not learned this from the history lessons at his school. However, he does point out that inhabitants of Michniów (most probably members of the local theater group) used to visit neighboring settlements to tell the history of their village. 
For the younger generations of Michniów inhabitants, it is their families rather than school that continue to be the most important sources of knowledge about the past. Crucially, an important role in this transmission of knowledge is played not only by the stories of witnesses, but also the non-material and material infrastructure commemorating the pacification, in particular, Song of Michniów and the area around the grave. One of the interviewees cited an example from his own family. After his niece had learned to sing Song of Michniów, he showed her where the events in the song had taken place: "I have a little niece, that Song of Michniów, my sister is really quite emotional, the grandma of this little one taught it to her. And that little mite can really sing. She's probably four years old at the moment... But a child already, I brought her here once with her parents to this place, because she was some four-year-old and already knew some of those verses that her mother, you know, had been repeating to her - they were about this, just so you know, it was here" (M, ca. 55 years old, Michniów, July 2015).

There are families, therefore, within which stories from history referring to the same commemorative elements are passed down from generation to generation. A large role is played here by the emotionality of the message. Due to the presence of these emotions and methods of morally assessing past events being shared within the community, even people who did not directly witness these events can share similar emotions to their ancestors ${ }^{226}$. However, the connection some of these families have with the place at which these events took place is crucial: "We, as inhabitants of Michniów, such natives as my husband and I, many people from our families died during the pacification, so we definitely experience things completely differently to those people who came later, because it's... it is remembered how, for example, my mother's sister died with her husband and child, another sister, two more sisters as well and so my mother, she was deeply affected [by the loss], and for as long as she lived, the twelfth and thirteenth of July were days of mourning. She always prayed a lot, she dressed in black" (F \& M, group interview, ca. 70 years old, Michniów, July 2015).

The memory of the murdered family members lives on through successive generations, reinforced by observation of the behavior of eyewitnesses to wartime events. The interviewee cited above recounts how her mother responded to successive anniversaries of the tragic events. However, the response of the interviewee's generation is not as emotional or strongly associated with

226 See Francesca Cappelletto, "Long-Term Memory of Extreme Events: From Autobiography to History." The Journal of the Royal Anthropological Institute, Vol. 9, No. 2, 2003. 
psychological pain as that of the generation that directly witnessed these events. There have even been cases when listeners from later generations have shown no interest in the witnesses' stories: "I remember that the man neither recorded nor noted down what he heard, because I was talking to a woman who was already of advanced age, from Michniów, an eyewitness to these events, she was saying how she lay somewhere in the potatoes unharmed, for as long as 48 hours as the burning continued... What a terrifying situation that was. Anyway, it didn't occur to the man to... She talked and talked in a similar manner. But little of this I remember, unfortunately" (F, ca. 65 years old, Michniów, July 2015).

A similar phenomenon once occurred in families. Only when the second generation reached maturity did they begin to realize how much knowledge about the past had been lost due to them not speaking to their parents about their wartime experiences: "That is to say in such conversations with older people, by which I mean our generation, we speak about it a lot. We regret that we didn't speak so much about this subject earlier... With our parents..." (F \& M, group interview, ca. 70 years old, Michniów, July 2015).

The gradually decreasing interest the next generations showed in the village's wartime past was perceived by the slowly vanishing generation of eyewitnesses. To this end, they have preserved the memory of the pacification throughout their lives, never losing their sense of the uniqueness of their village's fate and the huge effort they have put into commemorating it. Clearly, this generation wishes to be assured that Michniów's history will not be forgotten. Their restlessness and efforts are evident to museum staff: "Especially those inhabitants of Michniów, not only those people who survived the war, suffered somewhere during that war, or their families, [who] also realize that this history is being lost somewhere, needs to be shown somewhere, because they also see that sometimes their loved ones and their children or grandchildren are not really that interested in this history. But they want it to remain, to endure somewhere and this is how they are somehow saving it from oblivion" (F, ca. 45 years old, Michniów, July 2015). It appears from the observations of all the interviewees, both the oldest and youngest, that interest is slowly shrinking in the forms of remembrance that have been practiced to date.

According to a local teacher, young people's approach to history, including that of their immediate neighborhood, is changing. It is of such little interest to them that they do not even remember it:

As far as the schoolchildren are concerned... but these are ceremonies, as I was saying. Even I am terrified sometimes because even if there is some kind of commemorative ceremony at school, I've been trying to do that now, even if we tried to ask the children of 12 or 13 years old what it was about, [only] a few really do have some idea. It's another 
era. (...) There are no crowds, normally there are Michniów residents and those people who perhaps should be there. (...) This year, frankly speaking, I was counting on there being even more, but only because there are elections in the fall. Unfortunately [there weren't more], but that's how things look with us here too, and indeed there were more priority seats." (M, ca. 42 years old, Michniów, July 2015)

Since successive anniversaries ceremonies fail to attract broader interest, most of those who attend are older people and Michniów residents who wish to remember members of their own families. However, it is very clear that the ceremonies are still perceived as an event of social significance that is important to the local community because participating in these can form part of the campaigns of parliamentary candidates. The fact that the manner in which narratives of the past have been transmitted for decades is not getting through to the youngest generations is not a purely local phenomenon or one that only applies to the village. It is symptomatic of a broader global lifestyle change. According to one of the interviewees, when children can identify with the protagonists of stories about wartime events (for example, when they are children themselves) they are eager to listen to older people's stories. Nevertheless, such temporary instances of emergent interest in history do not alter the general outlook of social transformations:

Now children in the second and third grades write such things, I mean, they do group projects and one of them was really interested when he listened when his mother was telling him about these young children, as we also have a young child of this age... Look, I say, they were shown no mercy. (...). These days, everyone spends their lives rushing about trying to solve their own problems. It didn't use to be like this, because they only knew... there were no colorful objects, the older generation didn't know what was happening 200 or 300 kilometers away when we didn't yet have access to... don't you think? They concerned themselves with what was happening here, on their patch. But now everyone is turning this on, clicking that and disappearing upstairs. It's not like it was once, when everyone came out of their homes in the evenings to sit on their benches. That's all gone now. (M, ca. 42 years old, Michniów, July 2015)

The fundamental change, therefore, applies to the flow of information. Once this was obtained during conversations with residents of the same village. It was not only the latest news that was exchanged, but also memories (and such discussions were also conducive to the mutualization of memories because elements from some narratives could be incorporated into the stories of others ${ }^{227}$. These days, the Internet is the main source of such information. It has also changed the manner in which information is presented by shifting from textuality to visuality and expanding the range of possibilities (from multimedia and personalized 
searches to information interpretation). For this reason, many people view the new technologies appearing at the Mausoleum as offering the best chance for the memory of the Michniów Pacification to survive. For the local people, the best example that a technological approach of this kind can turn out to be successful is the Warsaw Uprising Museum (another project created by Nizio Design): "Because my son, for example, has already been to the Warsaw Uprising Museum, and liked it a lot. Maybe it doesn't necessarily appeal to older people, but young people like it very much" (M, ca. 42 years old, Michniów, July 2015).

Having observed the reaction of the youngest generation, the inhabitants of Michniów are beginning to think that even though such modern methods of presenting history may seem alien to them, they are the only chance of knowledge about the past being transferred down the generations. The Warsaw Uprising Museum is also an intriguing model for another reason which an employee of the local museum explains:

Much like the foundation of the Warsaw Uprising Museum, where suddenly the uprising began to be talked about. [It was said] that the memory wasn't only local or exclusive to Warsaw, but now it's [generally] known that there was an uprising [there]. And maybe thanks to this particular museum it will become known that the village also played an important role during the war. Because I... people are extremely surprised... there's a lot of tourist traffic, despite everything, just for the village and setting. That exhibition is all we have there, but if over twenty thousand people visit us every year, that's really a lot. And especially foreign tourists, where their eyes pop with amazement - 'How come? Poles died?' There is the talk of Polish Jews, the Holocaust, of such large-scale martyrological events of the Warsaw Uprising type, and for them... we heard that Jews, for example, were murdered in the countryside. And I say: but did you hear, for example, that in the countryside almost two-thirds of the Jews who survived were hidden in the countryside? That two-thirds of the partisan units lived in the countryside? That the village had to, for example, feed itself, the partisan units and the city? (F, ca. 45 years old, Michniów, July 2015)

The primary aim of the constructed Mausoleum is, therefore, to embed the village's importance to the history of Second World War Poland in the social consciousness (of both Polish citizens and people from other countries). The example set by the Warsaw Uprising Museum shows that an attractive form and skillful promotion can cause local history to become a recognizable element on both the national and international arena (though the reasons for this success are of course diverse $)^{228}$. In the meantime, according to the interviewee cited above,

228 Compare, for example, Maria Kobielska, Polska kultura pamięci w XXI wieku: dominanty. Zbrodnia katyńska, powstanie warszawskie i stan wojenny. Warsaw: IBL Wydawnictwo, 2016. 
the narrative of the village's wartime history can be woven into global Second World War narratives, such as resistance to occupying forces, the mass extermination of victims by the forces occupying Poland or the Holocaust and saving the Jews. Such references to widely known symbols of both martyrdom and the bestiality of the war years also appear in other statements. One of the interviewees claimed, when speaking of Michniów's potential to attract tourists, that: "this is like our region's miniature Auschwitz" (M, ca. 75 years old, Michniów, July 2015). This interviewee is also referring here to a widely known site of memory to show Michniów's importance to narratives of the history of the region and that of Polish villages. According to the museum employee cited above, this is history that is completely unknown outside Poland. As a matter of fact, even the narrative in Poland is fragmentary - particular events, people and places are spoken of, but there is no image in Polish society's collective memory of the contribution villages made to the resistance effort and the price they paid for this. Depicting this collective image combining the fates of the thousands of villages that existed in Poland before the war is to be the Mausoleum's primary task. In the view of the House of Remembrance's former director, this is an image that appeals to foreign visitors: "Of course most are English and German speakers. And all of them are astonished when they view our exhibitions, when they view our exhibits, astonished at the lack [of action] or indolence on the part of our authorities, astonished that we are not showing this to the world" (M, ca. 70 years old, Michniów, July 2015).

The notion of the central government in Poland underestimating the contribution the village made to the war effort is clearly reappearing here as a recurring motif. The Mausoleum offers hope that the local history - which, for many, has permanently defined their way of thinking, the emotions they associate with the past and the actions they have taken in their lives - will become recognizable on the national and international arena. Vernacular methods of commemoration and transmitting narratives of the past have finally reached the limits of their efficacy. As things stand, only modern methods of transmitting historical narratives and the involvement of national institutions are capable of ensuring that memory of the local victims will live on in the consciousness of Michniów's inhabitants and the whole world beyond the village's borders.

\section{Between Traditional and Modern Methods of Commemoration}

Memory of the Michniów Pacification is deeply embedded within this village's local community. For the majority of the villagers living their today, this memory 
is all the more important because it is family memory. The emotions that accompany their recollections of the past are therefore particularly strong because they are linked to their loved ones. Moreover, some people who were eyewitnesses of the burning of Michniów are still alive. However, the generations that remember the war from their own experiences are slowly passing away, so it is becoming crucially important to prepare a form of commemoration that will guarantee that their stories about the village's pacification survive into future generations. There is, therefore, a need to use a language that appeals to the youth of today. However, memory actors from Michniów and the surrounding region have also set themselves more far-reaching objectives - they want Michniów to become a center of the memory of the fates of Polish villages during the Second World War. An enterprise of this nature requires the assistance of such institutions as the peasants' party and Polish state, whose jurisdiction stretches beyond individual regions. The wartime fates of villages are also defined as "forgotten", since no place has been found for them in the official state memory narratives. They are not being discussed widely in course books, no films about them are appearing and they are not becoming symbols that are recognizable across the country as a whole (or even in other countries). Consequently, vernacular memory actors regard it as their duty to show the fate of their own village (and other rural communities) to the whole of Poland and across the world. However, this means changing the language used to narrate the past. This new language is accepted locally in those domains where it does not infringe on traditional modes of remembrance of a strictly religious nature that have been developed over many years. These traditional and modern methods of commemoration function in parallel at separate sites within the village space. One such site associated with traditional methods of commemoration is the chapel, while modern methods are practiced at such sites as the Mausoleum building. However, there are also parts of the village space that are shared between them. This first of these is the Forest of Crosses, which is in fact to be given a modern makeover, yet will retain its original religious meaning, which renders human suffering in the language of Christianity. The second of these is the victims' grave itself, which has a religious dimension, like any burial site consecrated in accordance with the appropriate religious rites. However, the fact that a modern form of commemoration in the form of a mausoleum is also perceived as an anchor of authenticity reminds visitors that they are in a place where a wartime tragedy actually took place and where its victims' remains are buried to this day. 


\section{Jedwabne}

In 2000, Jan Tomasz Gross published a book in Polish titled Neighbors: The Destruction of the Jewish Community in Jedwabne 229 that transformed Jedwabne into a globally recognizable symbol of the Holocaust, or, for others, a symbol of Polish anti-Semitism. Gross's book, which tells of a crime the Polish inhabitants of Jedwabne committed against their Jewish neighbors in 1941, suddenly thrust the inhabitants of this small town in the Podlasie region into the very center of a national debate on relations between ethnic and Jewish Poles during the Second World War and Polish attitudes toward the wartime fate of Jews in Poland ${ }^{230}$. As Piotr Forecki writes, "this was the debate that was the longest, profoundest and involved the largest number of participants"231. It flared up on the eve of the sixtieth anniversary of the crime, so the Polish authorities decided to honor the memory of the Jews murdered by their Polish neighbors by erecting a national memorial in 2001 and organizing remembrance ceremonies that involved the President of Poland, Alexander Kwaśniewski. For the incumbent Polish government, the head of state's involvement in the Jedwabne ceremonies was

229 In English, the book was published in 2001 by Princeton University Press, 2001. All references in this chapter are to the English publication.

230 See Barbara Törnquist-Plewa, "The Jedwabne Killings - A Challenge for Polish Collective Memory." In: Echoes of the Holocaust. Historical Cultures in Contemporary Europe, eds. Klas-Görnan Karlsson and Ulf Zander. Lund: Nordic Academy Press, 2003, pp. 141-177; Ewa Wolentarska-Ochman, "Collective Remembrance in Jedwabne. Unsettled Memory of Second World War in Postcommunist Poland." History and Memory, Vol. 18, No. 1, 2006, pp. 152-178; Marek Czyżewski, "Debata na temat Jedwabnego oraz spór o 'politykę historyczną’ z punktu widzenia analizy dyskursu publicznego." In: Pamięć i polityka historyczna. Doświadczenia Polski i jej sąsiadów, eds. Sławomir M. Nowinowski, Jan Pomorski, Rafał Stobiecki. Łódź: Instytut Pamięci Narodowej, 2008; Marek Czyżewski, "Polski spór o Strach Jana Tomasza Grossa w perspektywie 'pośredniczącej' analizy dyskursu." Studia Socjologiczne, Vol. 3, No. 194, 2009, pp. 5-26; Piotr Forecki, Od Shoah do Strachu. Spory o polsko-żydowska przeszłość i pamięć w debatach publicznych. Poznań: Wydawnictwo Poznańskie, 2010; Magdalena Nowicka, "Dynamika pamięci publicznej. Debata wokół książki Jana Tomasza Grossa a wybrane spory o pamięć zbiorową.” Kultura i Społeczeństwo, Vol. 3, 2014, pp. 237258; Sławomir Kapralski, “The Jedwabne Village Green?: The Memory and CounterMemory of the Crime." History and Memory, Vol. 18, No. 1, 2006, pp. 179-194.

231 Piotr Forecki, Spór o Jedwabne. Analiza debaty publicznej. Poznań: Wydawnictwo Naukowe Instytutu Nauk Politycznych i Dziennikarstwa UAM, 2008, p. 5. 
of symbolic importance. The year before, the countries of Europe had signed the Stockholm Declaration, which underlined the exceptional nature of the Holocaust experience and called for an education program, remembrance activities and more research on the Holocaust. The official apology Kwaśniewski gave for the crime committed in Jedwabne was supposed to demonstrate that Poland was a country ready to confront its difficult past and subscribe to the same values as other Europeans ${ }^{232}$. Ten years after these ceremonies, Aleksander Kwaśniewski commented on them as follows: "The commemoration of the slaughter site, the dignified homage paid to the crime's victims, the crime's documentation by historians from the IPN [Institute of National Remembrance] and ultimately, the presidential address all demonstrated that we have matured enough as a state to confront history that is very difficult for us"233. However, for Jedwabne natives, as one of the town's inhabitants would tell us in 2016, "What happened here in 2001 is a tragedy for us" (F, ca. 35 years old, Jedwabne, August 2016).

In this chapter, we treat the debate of 2000-2001 as an event that not only influenced how the events of 1941 were perceived and remembered, but also how Jedwabne's residents decided to construct their identity over the years that followed. For us, it is the kind of event that bears the hallmarks of a local cultural trauma that not only impacts the ongoing life of a community, but also its attitude to the past. As Piotr Sztompka writes, cultural trauma arises when "some kind of disorganization, confusion or lack of cohesion appears in an existing social structure, in other words, when the context of human life and social actions loses its homogeneity, coherence or stability"234. Social change is traumatic when it is sudden, radical, and impinges on social life's very essence. Furthermore, it is perceived as having been imposed from the outside, unanticipated and unpredictable ${ }^{235}$.

232 Poland was trying at the time to meet the conditions for accession to the European Union, which ensued on 1 May 2004, and the issue of recognizing the Holocaust as a foundation of European identity. Critically assessing its own attitude to the Jews' wartime fate was one of the crucial components of the negotiations among the states of Central and Eastern Europe before EU accession.

233 "Kwaśniewski o Jedwabnem: 'Przeprosiłem i nie żałuję" ("Kwaśniewski on Jedwabne: 'I apologized and have no regrets"”), an interview the ex-president gave to Emilia Świętochowska of Newsweek on 3 Feb, 2001. Retrieved from http://www.newsweek. $\mathrm{pl} /$ polska/kwasniewski-o-jedwabnem--przeprosilem-i-nie-zaluje,78902,1,1.html (last accessed 5 May 2018).

234 Piotr Sztompka, Trauma Wielkiej zmiany. Społeczne koszty transformacji. Warsaw: Instytut Studiów Politycznych PAN, 2000, p. 22.

235 Sztompka, Trauma Wielkiej zmiany, p. 22. 
In this chapter, we show how the war and mass murder of Jedwabne's Jewish inhabitants functioned in vernacular memory both before and after the debate of 2001 flared up. Our main concern is to show how the national debate was centered around the crime in Jedwabne and how the construction of a memorial commemorating the murdered Jews (erected against the wishes of the town's inhabitants) became a cultural trauma for Jedwabne's inhabitants that influenced how they remembered the crime. We also show that the local residents decided to counter the effect of this trauma by undergoing "monument therapy". Jedwabne's inhabitants responded to the erection of the national memorial in their town by erecting or restoring other monuments alluding to the war period. We, therefore, also show what kind of monuments they erected after 2001, and where they did this; and what place these monuments occupy and what function they perform in local vernacular memory. In effect, we are reconstructing the history of the local residents' construction of an alternative history for their town. At the same time, however, we make clear that the Jedwabnians are a community whose life is focused around church holidays and rituals, which explains why the only monuments in Jedwabne that have a social function allude to a tradition of erecting crosses and blend in with the cultural landscape.

\section{Jedwabne During the Second World War}

Jedwabne is a small town with a population of about 500 in the northeastern part of Łomża County in the Podlaskie Voivodeship. It is about 80 kilometers from Białystok, the capital of the Podlaskie Voivodeship, and first appears in historical records in the mid-fifteenth century. It received town privileges in the eighteenth century, losing them after the 1863-64 January Uprising, only to regain them in 1927. For centuries, Jedwabne was a Polish town with a large Jewish population.

Establishing exactly how many people of Jewish and Polish ethnicity inhabited Jedwabne before the outbreak of Second World War is no easy task because, as Marcin Urynowicz's analysis of documents and records dating from this period shows, the demographic situation was extremely fluid at the time ${ }^{236}$. In the 1920s, there were probably more Jewish than non-Jewish residents. However, by the 1930s the situation had reversed. This was the outcome of intensive economic migration as well as worsening relations between non-Jewish Poles and Polish

236 Marcin Urynowicz, "Ludność żydowska w Jedwabnem. Zmiany demograficzne od końca XIX wieku do 1941 roku na tle regionu łomżyńskiego." In: Wokót Jedwabnego. Vol. 1. Studia, eds. Paweł Machcewicz and Krzysztof Persak. Warsaw: Instytut Pamięci Narodowej, 2002, p. 96-97. 
Jews provoked by the anti-Semitic excesses of the National Democracy movement, ${ }^{237}$ which was particularly active in this region ${ }^{238}$.

The Catholic Church exerted a large impact on the worsening relations between Polish Jews and non-Jewish Poles. As Dariusz Libionka writes: "the Łomża diocesan press, much like all the Catholic press of the time, fulminated against the 'Judaization' of Polish cultural life and decline in European and Catholic values"239. They struck fear into their readership by warning them of the specter of a "Judeo-Polonia" looming on the horizon and the arrival of a Żydokomuna (Jew Commune) ${ }^{240}$. The Catholic press priests distributed among their parishioners was full of anti-Semitic slogans that called for the nationalization of the economy. Jewish shops began to be boycotted, shop windows were smashed, and market trade was obstructed as the physical violence escalated. As Lebionka writes, one of the most serious incidents occurred on 23 March 1933 in Radziłów, not far from Jedwabne. Camp of Great Poland ${ }^{241}$ activists freed their

237 National Democracy was a Polish nationalist movement founded at the end of the nineteenth century. Its primary ideologue and co-founder was Roman Dmowski. Dmowski was also the foremost ideologue of Polish nationalism and a rival to Józef Piłsudki, whose notion of a multi-ethnic country he opposed.

238 Urynowicz, "Ludność żydowska w Jedwabnem”, p. 93.

239 Dariusz Libionka, "Duchowieństwo diecezji łomżyńskiej wobec antysemityzmu i zagłady Żydów. In: Wokół Jedwabnego. Vol. 1. Studia, eds. Paweł Machcewicz and Krzysztof Persak. Warsaw: Instytut Pamięci Narodowej, 2002, p. 111; Anna Bikont, The Crime and the Silence: Confronting the Memory of the Burning of Jews by Their Neighbors in Wartime Jedwabne. Trans. By Alissa Valles. New York: Farrar, Straus and Giroux, 2015, p. 27-28. The Polish version of this book was first published in 2004 under the title My z Jedwabnego. All references in this chapter are to the English edition.

240 The Żydokomuna is a stereotype ascribing the primary role in the creation of communism to Jews. Communism was meant to open up a path for Jews to acquire power over the whole world. In Poland, this term was used by National Democracy in their propaganda. As Michael Steinlauf writes: "Even before the Soviet invasion of eastern Poland, the Żydokomuna (Jew Commune) had occupied a prominent place in nationalist diatribes. Here, supposedly, was the modern means to the long-attempted Jewish political conquest of Poland; the Żydokomuna conspirators would finally succeed in establishing a 'Judeo-Polonia." See Michael C Steinlauf, "Poland." In: The World Reacts to the Holocaust, ed. David S. Wyman. Baltimore and London: The Johns Hopkins University Press, 1996, p. 103.

241 Camp of Great Poland (Obóz Wielkiej Polski) was a radical political nationalistic organization initiated by Roman Dmowski in 1926 to combine the forces of opponents of the government having rightwing and nationalistic views. 
comrades from a police station and then proceeded to "demolish and loot Jewish business establishments". Several dozen people were injured and two died ${ }^{242}$. The Germans entered Jedwabne on 2 September 1939, looting, destroying, and humiliating the Jews, which may explain the perception that "For most Jews the Soviet occupation also meant hard times, but it offered some hope of surviving"243. Marek Wierzbicki writes that the Red Army was in fact welcomed by local Jews when it arrived. However, this did not apply to all the Jews living there: "They were so conspicuous that they were clearly remembered [later] by their Christian neighbors. Most of the welcoming party were young people, the poor and refugees from central Poland"244. A similar conclusion was drawn by Bikont, who notes that "the clear majority of the religious community of merchants and craftsmen could not possibly be happy with the Soviet system, which was atheistic and deprived them of their private property" ${ }^{245}$. Consequently, contrary to the ingrained stereotype that all Polish Jews supported the Soviet soldiers, the collaborators actually comprised both Jewish and non-Jewish Poles.

By 27 September 1939, the town had been occupied by the Red Army. The nationality policy in this region underwent a radical change after it was annexed by the Soviet Union. The Poles who lived there were repressed. Many were deported to Asian parts of the USSR as part of a nascent program of depolonization. Initially, local Polish elites were hit the hardest, as estates mainly belonging to the landed gentry were confiscated ${ }^{246}$. The Jews were treated as a harmless group. Initially, they were used to build new power structures, but they were later replaced by specialized personnel brought in from the USSR ${ }^{247}$.

The arrest and deportation of members of the Polish population to the furthest reaches of the USSR, including Kazakhstan and Siberia, began apace. In February 1940, military and civilians and foresters were deported and in April 1940, the same happened to the families of the policemen, senior officials, political party leaders, and local intelligentsia who had been arrested earlier. As Wierzbicki writes: "local Jews - local government officials or militia - were in

242 Libionka, “Duchowieństwo diecezji łomżyńskiej”, p. 113.

243 Bikont, The Crime and the Silence, p. 169.

244 Marek Wierzbicki, "Stosunki polsko-żydowskie na Zachodniej Białorusi w latach 1939-1941.” In: Wokół Jedwabnego. Vol. 1. Studia, eds. Paweł Machcewicz and Krzysztof Persak. Warsaw: Instytut Pamięci Narodowej, 2002, p. 131.

245 Bikont, The Crime and the Silence, p. 168.

246 Wierzbicki, "Stosunki polsko-żydowskie", p. 139.

247 Wierzbicki, "Stosunki polsko-żydowskie”, p. 141. 
many cases helping the Soviet authorities to track them down"248. However, the third deportation transport, which departed in June 1940, also included refugees from the General Government, mainly Jews. This explains why, as Bikont writes, "June 1940 went down in history as the time of great deportations, while Poles remember it as the time of the NKVD raid on the Kobielno wilderness area on the Biebrza river, where partisans and people evading imprisonment or selection for deportation were hiding in inaccessible swampy terrain"249. The partisan units stationed in the Kobielno reserve were annihilated by the Soviets.

In June 1941, two days before the outbreak of the Soviet-German War, the last deportation of prisoners' families began. The Soviets planned to evacuate the prisons but did not manage this in time. However, they did manage to deport the wives, families, and children of those who had been arrested. As Tomasz Szarota shows, the Laudański brothers, who left the NKVD prison a few days before the later pogrom, were among those who murdered the Jews ${ }^{250}$.

The first pogroms and murders took place as soon as the Red Army left in June $1941^{251}$. The first pogrom, which took place in Białystok on 27 June, was followed by others in Wąsosz ( 5 July) and Radziłów (7 July). The few who managed to survive sought shelter in neighboring villages and towns, including Jedwabne. The pogrom there took place on 10 July, but over the previous few nights, the Poles had already been raiding Jewish homes, murdering several families. The mass murder began on the morning of 10 July and was led by Marian Karolak, who had been elected as Mayor of Jedwabne on 23 June 1941. The Jews were ordered to gather in the Main Market Square, where they were forced to weed the grass. Those who did not want to leave their homes or fled were cruelly murdered on the spot. The Jews were ordered to remove the statue of Lenin erected during the Soviet occupation of this region and take to it to a barn owned by Bronisław Śleszyński. Next, all the Jews were driven into the barn, which was doused in gasoline and set alight. Those attempting to flee were killed.

A precise description of the course of events can be found in the witness testimony of Shmuel Wasserstein, who fled the pogrom and was subsequently hidden, along with six other Jews, by the Wyrzykowski family in the village of Janczewko.

248 Wierzbicki, “Stosunki polsko-żydowskie”, p. 139.

249 Bikont, The Crime and the Silence, p. 180.

250 Tomasz Szarota, "Mord w Jedwabnem. Dokumenty, publikacje i interpretacje z lat 1941-2000. Kalendarium”. In: Wokót Jedwabnego. Tom 1. Studia, eds. Paweł Machcewicz and Krzysztof Persak. Warsaw: Instytut Pamięci Narodowej, 2002, pp. 461-488.

251 Libionka, “Duchowieństwo diecezji łomżyńskiej”, p. 119. 
On 5 April 1945, Wasserstein gave evidence on the murder in Jedwabne before the Jewish Historical Commission in Białystok. It is this testimony, now housed in the archives of the Jewish Historical Institute in Warsaw, that formed the basis of Tomasz Gross' book Neighbors.

The Wyrzykowski family, who rescued the seven Jews, were subjected to repeated harassment after the war by Polish partisans. Antonina Wyrzykowska was severely beaten by local partisans because she did not want, in 1945, to hand over to them the last Jew she was hiding in her home ${ }^{252}$. This led to the Wyrzykowskis leaving Jedwabne and settling in Milanówek, just outside Warsaw. In 1976, Antonina and her husband Aleksander received the title of Righteous Among the Nations from Yad Vashem. Antonina Wyrzykowska stayed in contact with the Jews she had rescued to the very end of her life.

Another person who helped the Jews was Stanisław Ramotowski, who rescued Rachel Finkelstein from the pogrom by marrying her (she accepted baptism on 17 July 1941; the wedding took place on 9 September 1941). Both of them had to hide during the war $^{253}$. After the war, everyone knew that "Marianna" Ramotowska was of Jewish origin, but no one persecuted her because Stanisław Ramotowski, as he himself explained, was respected as a Home Army (AK) partisan. Izrael Grądowski also stayed in Jedwabne. Some of his family had died in the pogrom of 10 July 1941. He managed to survive with his wife and children, but they were incarcerated in the ghetto created in Jedwabne immediately after the pogrom. About a 100 of the surviving Jews were detained there ${ }^{254}$. In the fall of 1942, the ghetto was liquidated and the Grądowski family were transported with the other Jews to Łomża. From there, his wife and children were transported to the death camp at Treblinka. Grądowski escaped and was hidden by the Wyrzykowskis. After the war, he converted to Christianity, taking the name Józef and marrying his former housekeeper.

In the mid to late 1940s, Grądowski was a member of a criminal group involved in the illegal seizure of Jewish property. He often passed himself off as a relative of murdered Jews, assisting in this way with the appropriation of their property during the court cases that took place from 1947 to 1949 at the magistrates' court in $Ł o m z ̇{ }^{255}$. The cases relating to Jedwabne's deceased Jewish residents were conducted on the basis of a decree, dated 8 March 1946, on property abandoned

252 Bikont, The Crime and the Silence, p. 374.

253 Bikont, The Crime and the Silence, pp. 64-83.

254 Czesław Pilichowski, Obozy hitlerowskie na ziemiach polskich 1939-1945. Informator encyklopedyczny. Warsaw: Państwowe Wydawnictwo Naukowe, 1979, p. 208.

255 Krzysztof Persak, “Akta procesu z 1953 roku Józefa Sobuty oskarżonego o udział w zbrodn na ludności żydowskiej w Jedwabnem.” In: Wokót Jedwabnego. Tom 2. 
during the war (or whose owners were killed or died during the war) or belonged to Germans before the war ${ }^{256}$.

In 1949, the first trial against the Jedwabne residents participating in the massacre of Jews in 1941 was held. Twenty-two residents of Jedwabne were charged under a decree adopted on 31 August $1944^{257}$ on "the appropriate punishment for fascist Nazi criminals guilty of murdering and harassing the civilian population and prisoners-of-war and traitors to the Polish Nation"258. The impetus to initiate criminal proceedings in the case of the massacre of the Jedwabnian Jews was provided by a letter from Całka Migdał to the Central Committee of Jews in Poland, written on 29 December 1947 in Montevideo in Uruguay. In this letter, Migdał called for the murderers to be brought to justice. The letter was presented to the Ministry of Justice along with an account of events given by Shmuel Wasserstein on 5 April 1945 in Białystok. The Ministry responded

Dokumenty, eds. Paweł Machcewicz and Krzysztof Persak. Warsaw: Instytut Pamięci Narodowej, 2002c, pp. 720-21.

256 The aim of the new decree was to legitimize the appropriation of such property.

257 This decree, sometimes knows as the August Decree, provided for the death penalty for murder, harassment, and other forms of persecution of the civilian population and prisoners-of-war; and a prison term for blackmail that involved a ransom being demanded to prevent the victim from being denounced to the German authorities. The decree was used to prosecute and convict collaborators; szmalcownicy (people who had blackmailed Jews in hiding or those who were hiding them) and people responsible for complicity in the Holocaust; soldiers and activists operating on behalf of underground organizations; and civilian activists working for the Polish Underground State, which was loyal to the Polish government-in-exile. Drawing on Leszek Kubicki's findings, Andrzej Rzepliński writes that 16,819 people were convicted in 1946-60 on the basis of the August Decree. See Andrzej Rzepliński, "Ten jest z ojczyzny mojej? Sprawy karne oskarżonych o wymordowanie Żydów w Jedwabnem w świetle zasady rzetelnego procesu". In: Wokót Jedwabnego. Vol 1. Studia, eds. Paweł Machcewicz and Krzysztof Persak. Warsaw: Instytut Pamięci Narodowej, 2002, p. 354. He draws attention to the fact that Germans made up only $25 \%$ of the total number of those convicted, the majority of whom were Poles, but also Belarusians, Ukrainians and representatives of other nationalities. There is no data for the 1944-45 period. Rzepliński, “Ten jest z ojczyzny mojej?”, p. 355; endnote 8. For the decree, see Adam Lityński, Historia prawa Polski Ludowej. Warsaw: LexisNexis, 2005.

258 The full text of the decree can be found at: http://static1.money.pl/d/akty_prawne/ pdf/DU/1946/69/DU19460690377.pdf (last accessed 1 June 2018). 
quickly, sending both letters as evidentiary material to the Regional Court in Łomża. Nonetheless, an investigation was not commenced until the beginning of $1949^{259}$.

On 17 May 1949, the court convicted 12 and acquitted ten of the accused ${ }^{260}$. The justification of the sentence stated that: "colluding with the German state authorities - they participated in the capture of around 1,200 people of Jewish nationality, a large number of whom were burned to death in Bronisław Śleszyński's barn"261. The verdict also stated that the Germans murdered the Jews of Jedwabne aided by elements of the local population "drawn in by the violence". Finally, there is an annotation stating that: "As to the gravity of the crimes committed by the accused, it should be stressed [that this is an example of] mass crime against 1,500 defenseless people [of a nature] rarely encountered in the history of humanity"262.

The court sentenced the defendant Karol Bardon to death, basing its decision on the fact that he had taken part in the pogrom of his own free will. In January 1950, Bolesław Bierut ${ }^{263}$ pardoned him and commuted the death sentence to 15 years in prison, where Bardon remained for the rest of his life. The remaining defendants received custodial sentences of between 8 and 15 years. All of them appealed but must of their cases were dismissed. The last one to be released was Jerzy Laudański, who received conditional bail on March 1957. Apart from Karol Bardoń, Stanisław Zejer also died in prison. Krzysztof Persak writes that these sentences were severe by the standards of the time.

In 1953, another trial began. On this occasion, Józef Sobuta was seated on the bench of the accused. Although he had been named by many witnesses and suspects during the criminal proceedings in 1949 as one of the main organizers of the massacre, he had not stood trial at the time because he had been receiving psychiatric treatment at a hospital. When the Germans arrived, Sobuta became the deputy mayor, answerable to Marian Karolak. He was not only charged

259 A description of the trial and the court files were collected by Krzysztof Persak and published by the IPN, see Krzysztof Persak, "Akta procesu z 1949 roku dwudziestu dwóch oskarżonych o udział w zbrodni na ludności żydowskiej w Jedwabnem." In: Wokót Jedwabnego. Vol 2. Dokumenty, eds. Paweł Machcewicz and Krzysztof Persak. Warsaw: Instytut Pamięci Narodowej, 2002b, pp. 415-712.

260 Persak, "Akta procesu z 1949 roku", p. 429.

261 Persak, "Akta procesu z 1949 roku”, p. 591-92.

262 Quotation after Persak, "Akta procesu z 1949 roku", p. 597.

263 Bolesław Bierut was a communist politician and President of the Republic of Poland between 1947-1952. 
with complicity in the massacre but also of "handing over Czesław Kupiecki, a policeman during the Soviet occupation, to the German military police"264 and "drawing up lists of people to be sent to Germany for forced labor" ${ }^{265}$. He was eventually acquitted due to lack of evidence.

In 1961, the twentieth anniversary of the Jedwabne massacre, the first memory marker commemorating Jedwabne's Jews was erected at the scene of the crime. It bore the inscription: "The site of the slaughter of the Jewish population. The Gestapo and Nazi military police burned 1,600 people alive 10 July 1941". According to Tomasz Szarota, the stone was probably erected on the initiative of the local chapter of the Society of Fighters for Freedom and Democracy $(\mathrm{ZBOWiD})^{266}$. It was tended to by pupils from the local comprehensive high school as well as the ZBOWiD chapter ${ }^{267}$.

In 1966, the Regional Commission for the Investigation of Nazi Crimes in Białystok came into operation, immediately instituting several proceedings against Germans who had committed crimes in the Białystok Voivodeship. As Krzysztof Persak writes, "one of them was an investigation numbered Ds.-24/67 [relating to] 'the case of the immolation in a barn of 1,600 Jews in Jedwabne, Łomża County, by Germans in July 1941' '268. The investigation took place between 1967 and 1974. Many witnesses were questioned, but no convictions were obtained. As Krzysztof Persak writes, most of the materials collected at the time were not reliable enough sources to reconstruct the course of events accompanying the massacre of Jedwabne's Jews. Some of the witnesses' testimonies contradicted their earlier testimonies ${ }^{269}$. Persak writes that the prosecutor Waldemar Monkiewicz tried to find confirmation in the documents that the Germans were guilty of the massacre. In the 1980s, the local press published several of his articles that attempted to prove that the Jews had been murdered by the

264 Persak, "Akta procesu z 1953 roku Józefa Sobuty”, p. 713.

265 Persak, "Akta procesu z 1953 roku Józefa Sobuty", p. 715.

266 Szarota, "Mord w Jedwabnem”, p. 472. On history of ZBOWiD see Wawrzyniak, Veterans, Victims, and Memory.

267 Jan Onacik, Przewodnik po miejscach walk i męczeństwa woj. białostockiego, lata wojny 1939-1945. Warsaw: Wydawnictwo Sport i Turystyka, 1970, p. 114.

268 Krzysztof Persak, "Akta śledztwa z lat 1967-1974 prowadzonego przez Okręgową Komisję Badania Zbrodni Hitlerowskich w Białymstoku w sprawie zbrodni na ludności żydowskiej w Jedwabnem.” In: Wokół Jedwabnego. Vol 2. Dokumenty, eds. Paweł Machcewicz and Krzysztof Persak. Warsaw: Instytut Pamięci Narodowej, 2002d, p. 817.

269 Persak, “Akta śledztwa z lat 1967-1974”, p. 826. 
German "Kommando Bialystok" 270 . These were not the only articles to appear in the local press. In the 1980s, an increasing number of historians and journalists began to become interested in what had happened in Jedwabne in 1941. In 1986, the local magazine Ziemia Łomżyńska published an article by local historian Zdzisław Sędziak describing the fate of the Jews under German occupation in Łomża County. Two years later, on 10 July 1988, the forty-seventh anniversary of the crime, the local Łomża newspaper Kontakty published a report by Danuta and Aleksandra Wroniszewski titled “...aby żyć” (“...to live”). The authors reference extensive passages from Shmuel Wasserstein's account, which they came across during their research at the Jewish Historical Institute in 1986. However, their article attracted little attention. Not until the publication of Jan Tomasz Gross's book did the issue of the Jedwabne massacre become widely known, not only within, but also outside, Poland.

In 2000, the incumbent mayor of Jewabne, Krzysztof Godlewski, went to the memorial erected in 1961 to lay flowers he had purchased himself. They contained the following message: "In memory of the murdered Jewish residents of Jedwabne, and as a warning to others. From the Community"271 (Bikont 2015: 336). Bikont cites Godlewski, who explained that through this action and his subsequent assistance with the organization of the state ceremonies, he wished to help local residents work through the trauma. As he went on to explain: "I see how hard it is for residents to live with the consciousness that Jedwabne is seen as a town of murderers. I had an idea for turning this around"272. Despite his efforts, he was unable to achieve this. Immediately after the state ceremonies that took place on 10 July 2001, the City Council relieved Godlewski of his duties as the town's mayor.

At that time, a further investigation into the Jedwabne murder case that had been begun in August 2000 was still in progress. On this occasion, it was being conducted by the Institute of National Remembrance. On 9 July 2002, the prosecutor, Radosław Ignatiew, informed the public about the investigation's final findings. These stated: "Insofar as the Polish population's complicity in the execution of the crime is concerned, it should be accepted that this played a decisive role in the execution of the murderous plan [...] it should be stated that it is justified in a criminal law assessment to assign blame for this crime to the Germans as its perpetrators sensu largo [in a broad sense - P.M.]. The executors

270 Persak, “Akta śledztwa z lat 1967-1974”, p. 826.

271 Bikont, The Crime and the Silence, p. 336.

272 Bikont, The Crime and the Silence, p. 338. 
of this crime, as perpetrators sensu stricto [in a strict sense - P.M.] were the Polish residents of Jedwabne and its environs - at least 40 men"273.

\section{The Massacre of 10 July 1941 and Its Contemporary Interpretation}

There is a consensus among historians that the pogrom of 10 July 1941 resulted in almost all the town's Jewish inhabitants losing their lives. Historians also concur as to the general course of events. The Jews were rounded up on the main market square, where they were forced to weed the grass. They were then forced to take the Lenin monument to the barn belonging to Bronisław Śleszyński, where they were burned alive. Historians also agree that the crime in Jedwabne was possible due to the existence of specific social conditions provoked by the Third Reich's surprise attack on the USSR on 22 June 1941, which led to the Soviets suddenly retreating from the part of Poland they had been occupying. Historians show that pogroms following a very similar scenario to the pogrom in Jedwabne also occurred at other times and locations, so what happened in Jedwabne can only really be fully understood by analyzing it within a wider temporal and spatial context. At this juncture, the first problem of interpretation arises because different researchers define this broader context in different ways. Should consideration only be given to the period from the beginning of the Second World War and attempts to comprehend the specific nature of the Soviet occupation of this area? Or maybe the pogrom's causes should be sought in the interwar period and the social equalities that were prevalent at the time, above all, the nationalistic ideology that found fertile ground in this particular area, since it received additional support from the Catholic Church ${ }^{274}$ ? Despite historians agreeing that both the interwar period and that of the Soviet occupation are important, different historians place an emphasis on different elements or, more often than not, interpret the same documents or events differently from one another.

However, the main dispute between historians relates to the murderers' actual identity. Were they Germans or Poles forced or inspired by the Germans, or maybe Poles who committed the crime after gaining the Germans' consent? In spite of the investigation into the Jedwabne murder case conducted by the Institute of National Remembrance (IPN) in 2001, historians are yet to uncover

273 Quotation after Paweł Machcewicz, “Wokół Jedwabnego.” In: Wokół Jedwabnego. Vol 1. Studia, eds. Paweł Machcewicz and Krzysztof Persak. Warsaw: Instytut Pamięci Narodowej, 2002, p. 17.

274 Dariusz Libionka, “Duchowieństwo diecezji łomżyńskiej”, pp. 105-128. 
any sources that could provide a conclusive answer. Significantly, there are differences of opinion among the historians who actually conducted the research required for the IPN investigation. Tomasz Szarota writes: "the Germans' role in Jedwabne has still not been altogether clarified, though there is a great deal of circumstantial evidence that it was significantly larger than Gross's findings would suggest. It is very possible that in the case of Jedwabne, we are dealing with what was termed a "self-purification action" organized by a unit belonging to the operational groups. However, as things stand, conclusive evidence of this is lacking. I personally believe that SS-Hauptsturmführer Wolfgang Birkner, commander of the "Commando Bialystok" was responsible for the Jedwabne massacre (...)"275. In support of his thesis, Szarota cites the existing historical sources that Gross did not consult when writing his book. They show that these groups could have been dispersed across the Białystok region. This thesis is contested by Sylwia Szymańska and Andrzej Żbikowski, who in the first instance refer to documents produced by a delegation of the Republic of Poland that informed the government-in-exile in London that the people inhabiting this area were ill-disposed toward the Jews and welcomed the Germans enthusiastically. Secondly, the authors write that "in the period that concerns us most (June - July 1941), the German authorities in this area essentially relied on small, understaffed military police stations. The field commands (Feldkommandanturen) organized here implemented German policy," but they go on to add that they were not sufficiently organized at that point. The main goal of the Third Reich's field commands at the time was to uncover and liquidate those who sympathized with the previous government. For this, they needed the help of the local community ${ }^{276}$. For Szymańska and Żbikowski, this proves that the Poles were neither inspired nor acting under the influence of German pressure and that the killing of the Jews was undertaken on their own initiative.

Historians are also doubtful about the number of victims, as it is difficult to determine whether there were actually 1,600 of them, that is, more or less as many Jews as lived in Jedwabne before the war. This is the figure given in Shmuel Wasserstein's testimony, and also the number engraved on the first memorial, which was erected at the crime scene in the 1960s. However, many historians

275 Tomasz Szarota, "Mord w Jedwabnem”, pp. 462-63.

276 Sylwia Szymańska and Andrzej Żbikowski, "Relacje ocalałych Żydów o losach ludności Żydowskiej w Łomżyńskiem i na Białostocczyźnie po 22 czerwca 1941 roku”. In: Wokół Jedwabnego. Vol. 2. Dokumenty, eds. Paweł Machcewicz and Krzysztof Persak. Warsaw: Instytut Pamięci Narodowej, 2002, pp. 254-65. 
claim that there were far fewer victims. The Institute of National Remembrance's decision, taken on 30 June 2003, to dismiss the investigation mentions "no fewer than 340 "277 victims of Jewish nationality. All of these nuances and shifting emphases have transformed an interpretation of the crime that appeared to be indisputable and unequivocal following the publication of Gross's book into something increasingly vague and ambiguous. Those investigating the Jedwabne crime are split into two camps, those who view native Poles as being guilty of committing the crime (in particular, Jan Tomasz Gross ${ }^{278}$ and the journalist Anna Bikont ${ }^{279}$ ) and those who believe that the Germans either committed the crime themselves or forced others to commit it on their behalf (Marek Jan Chodakiewicz ${ }^{280}$; Tomasz Strzembosz ${ }^{281}$; Jerzy Robert Nowak ${ }^{282}$; Ewa Kurek ${ }^{283}$ ). Given the fact that Tomasz Strzembosz and Jerzy Robert Nowak were both awarded the title of honorary citizen of Jedwabne (in 2004 and 2006, respectively), it can be surmised that it is their evaluation of the events of 1941 that the Jedwabnians have adopted as their own. Certainly, it is this vision that the current municipal authorities are promoting and have adopted as their official proclamation on the issue. The local townspeople express themselves in a similar spirit when directly questioned about the meaning of the memorial and ceremonies. However, when such conversations are prolonged enough for the manner in which they speak of the mass murder of the Jews to be examined, it becomes clear that their attitude to what happened in 1941 is much more complex.

When we conducted our research in Jedwabne in 2016, the people we interviewed generally did not need to be prompted to begin talking about the memorial, which they called the "Jewish" monument, and the ceremonies in 2001. In fact, everybody was unanimous in their negative assessment of the ceremonies and regarded the memorial as an out-of-place memory marker imposed on them from above. As one female interviewee stressed, "as far as local residents

277 "Postanowienie o umożeniu śledztwa", http://www.ipn.gov.pl/ftp/pdf/jedwabne_ postanowienie.pdf (last accessed 25 Oct. 2018).

278 Gross, Neighbors.

279 Bikont, The Crime and the Silence.

280 Marek Jan Chodakiewicz, The Massacre in Jedwabne, July 10, 1941: Before, During and After. Boulder, CO: Columbia University Press 2005.

281 Tomasz Strzembosz, "Jedwabne 1941." Translated by Mariusz Wesolowski. 2000. http://www.antyk.org.pl/ojczyzna/jedwabne/strzembosz.htm/ (1 June 2018).

282 Jerzy Robert Nowak, Sto kłamstw J. T. Grossa o Jedwabnem i żydowskich sasiadach. Warsaw: Wydawnictwo von Borowiecky, 2001.

283 Ewa Kurek, Jedwabne - anatomia kłamstwa. Lublin: Wydawnictwo Clio, 2018. 
are concerned, no matter how divided they are on matters of class, earnings or voting preferences, when it comes to this topic, we are, I think, united" (F, ca. 35 years old, Jedwabne, August 2016). However, this assessment related to the events of 2001 rather than those of 1941. The residents did not speak to us about the latter, arguing that they did not directly witness the mass murder of the Jews. However, an awareness of the resounding ambiguity surrounding what had happened in Jedwabne in 1941 was evident in many of their statements. One female interviewee spoke of this as follows: "What I'll say is always, in every story, the greater part is the truth, but there's also a smattering of things that are preconceived, added on or transformed, so to speak, so... the same applies here to this matter of the Jews, does it not? So what I'm saying is I don't want to talk about this at all; I wasn't around in those times; it turned into a tragedy, but what really happened...? Everyone has something different to say" (F, 41 years old, Jedwabne, June 2016).

Another person made the following comment: "In any case, Poles did great harm to Jews and Jews did great harm to Poles too, for instance, the deportations to Siberia were more often than not inspired by the Jewish people" (F, ca. 35 years old, Jedwabne, August 2016). This comment would appear to be of particular interest, not only because it evokes the stereotypical image of the Żydokomuna but because it uses a comparison to temper the native Poles' guilt. Since other people we interviewed expressed similar opinions, it is fair to suppose that their knowledge of the events of 1941 is much greater than they officially declare. Nonetheless, they are loath to admit this to outsiders. As one of the female interviewees said, "At a certain point in time, things happened as they did and from 2001 I don't think anyone sent their child there [to the Jewish memorial] (...). Not because we stopped honoring the memory of these people or suddenly thought that didn't happen there. No, we'll never change history, but how we were treated [in 2001] as Jedwabnians, I think that was not fair" (F, ca. 35 years old, Jedwabne, August 2016). This is not an isolated statement. All the interviewees objected to the fact that their town, with its long history of which they are so proud, had become a negative symbol of global significance. Even though the Jedwabnians attitude to the events of 1941 was never clear or unequivocal, the image of the crime that prevails today is influenced by the events of 2001 . The latter act as a prism through which the former are interpreted.

\section{Memory of the Massacre of Jews in Jedwabne up to 2001}

Our knowledge of how memory of the Jedwabnian Jews functioned before the national debate in 2001 is fragmentary. What we have is mainly drawn from 
historical sources and the files of the court cases that took place after the war, which were later gathered into a collection of documents prepared by the IPN titled Wokót Jedwabnego ${ }^{284}$ (Concerning Jedwabne). We also have access to interview excerpts collected and published by Marta Kurkowska-Budzan, ${ }^{285}$ a historian native to Jedwabne who conducted research in her hometown before the debate exploded. In addition, we have transcriptions and extracts from interviews conducted by Anna Bikont, ${ }^{286}$ who regularly visited Jedwabne during the course of the debate and the recordings of statements made by local residents contained within Agnieszka Arnold's film Neighbors (2001). These materials are incomplete or fragmentary because they were collected in various historical periods and the motivations of those who collected the materials and those who spoke on them differ markedly from one another.

None of the documents the IPN commission managed to collect would be able to show how the Jedwabnians began to organize their lives after the mass murder. It is clear from the accounts that the Białystok journalists Danuta and Aleksander Wroniszewski ${ }^{287}$ (1988) collected when they visited Jedwabne to write an article about what had happened there during the war that the local residents had mixed responses to the massacre:

Two days afterwards I went to the town to visit my mother. So many people were arriving with carts for looting! The Germans didn't interfere in the least. Even with those people who were finding gold among the [bodies of the] dead. (...) I'm not afraid to speak about this because I didn't benefit from that burning at all. One feather quilt, two pillows and a wardrobe were all mom took for me. I had to be really inventive to get them out of there! We were staying with my mother-in-law and she was somewhat of a "tertiary": she prayed for the Jews, grieved for them and castigated those who profited from their misfortune ${ }^{288}$.

284 Paweł Machcewicz and Krzysztof Persak, ed. Wokół Jedwabnego. Tom 1. Studia. Tom 2. Dokumenty. Warsaw: Instytut Pamięci Narodowej, 2002.

285 Marta Kurkowska-Budzan, "Imaging Jedwabne. The Symbolic and the Real." Polish Sociological Review, Vol. 1, No. 137, 2002, pp. 113-117; Marta Kurkowska-Budzan, "My Jedwabne." In: The Neighbors Respond. The Controversy over the Jedwabne Massacre in Poland, eds. Antony Polonsky and Joanna B. Michlic. Princeton and Oxford: Princeton University Press, 2004, pp. 200-206; Marta Kurkowska-Budzan, "Jedwabne and Wizna. Monuments and Memory in the Łomża Region." Polin. Studies in Polish Jewry, Vol. 20, 2007, pp. 244-270.

286 Bikont, The Crime and the Silence.

287 Danuta and Aleksander Wroniszewski. “...aby żyć," Kontakty (Łomżyński Tygodnik Społeczny, Pismo PZPR), 10.07.1988, Vol. 27, No. 403, pp. 1, 8-9.

288 The Wroniszewskis. “...aby żyć”, p. 9. Tertiaries are members of a holy third order or religious association operating within the bosom of the Catholic Church who 
All that can be learned from the IPN investigation is that in August 1945 the Jedwabne authorities responded to a summons from the Main Commission for Investigation of Nazi Crime by recording in the questionnaire the Commission sent them that the massacre had been perpetrated by Germans ${ }^{289}$. However, it is not clear what factors guided their assessment of the incident. It is difficult to determine today whether this was routine conduct devoid of any political context or whether they were hoping to profit from having a site of memory in their possession or whether they wished to fend off potential accusations of being involved in the crime. The fact is that a few months earlier, at the beginning of April 1945, Shmuel Wasserstein had given his testimony of events in Białystok in the presence of Manachem Turk, who chaired the Jewish Provincial Historical Commission. Wasserstein's testimony described the course of the massacre of Jews in Jedwabne and implicated the town's non-Jewish Polish residents. It is not known whether Jedwabne's inhabitants were aware of the existence of Wasserstein's statement. However, it is known that rescued Jews gave their testimonies, which were published immediately. One example of such a publication is Szymon Datner's Walka i zagłada białostockiego getta ${ }^{290}$ (The Struggle and Extermination of the Bialystok Ghetto), published in 1946, in which the author describes murders committed "against the Jewish population with German approval by reactionary local riff-raff and hoodlums"291. The political situation in the Białystok region was very unstable in this period ${ }^{292}$. As Krzysztof Persak writes, the new people's government installing itself in these lands "in practice,

live according to the rule of the order they have selected (Franciscan, Dominican, Carmelite, etc.), but do not take holy vows. St Francis of Assisi is considered to have founded the first third order when he wrote a rule for laypersons who wished to share the ideals of his order without renouncing the secular aspects of their lives (Orlando O. Espín, James B. Nickoloff. An Introductory Dictionary of Theology and Religious Studies. Collegeville, MN: Liturgical Press, 2007, pp. 1363-64.).

289 Marcin Urynowicz, "Ludność żydowska w Jedwabnem. Zmiany demograficzne od końca XIX wieku do 1941 roku na tle regionu łomżyńskiego." In: Wokót Jedwabnego. Tom 1. Studia, eds. Paweł Machcewicz and Krzysztof Persak. Warsaw: Instytut Pamięci Narodowej, 2002, p. 102.

290 Szymon Datner, Walka i Zagłada białostockiego getta. Łódź: Wojewódzka Żydowska Komisja Historyczna w Białymstoku, 1946.

291 Tomasz Szarota, "Mord w Jedwabnem", p. 468.

292 The people's government was locked in a struggle with the armed anti-communist underground, which was very active in this area. See Kurkowska-Budzan, Antykomunistyczne podziemie zbrojne; also see Tomasz Danilecki (ed.). Podziemie Niepodległościowe w województwie białostockim. Warsaw: IPN, 2004. 
did not get as far as Jedwabne. Up until the amnesty in 1947, the Jedwabne region was controlled by post-AK nationalistic partisans and later on by the anti-communist underground. As late as September 1948, an anti-communist partisan unit commanded by Stanisław "Wiarus" Grabowski controlled the Commune Administration Office in Jedwabne, from where it removed, among other things, the tax books" ${ }^{293}$. In Jedwabne and the surrounding area there were spontaneous acts of revenge, as scores were settled, some of a political nature and others associated with the seizure of former Jewish property or the desire to remove eyewitnesses. Krzysztof Persak references a testimony in his analysis of civil court case files given by Aleksander Wyrzykowski, who had hidden seven Jews, including Shmuel Wasserstein, on his farm for two years, yet evasively stated when testifying before the magistrates' court in Łomża: "Piekarska died at the same time as all the Jews" ${ }^{\prime 294}$. Wyrzykowski did not indicate that the Germans perpetrated the crime but, according to Persak, his evasive response proves that he could have feared for his life. Surviving accounts show that he was harassed for helping the Jews and this is why he took the decision, in the end, to leave Jedwabne and settle down near Warsaw. As Persak writes, "The truth about the Poles' involvement in this crime must have been widely known in the first years after the war to the town's inhabitants (...). However, this truth was not intended for outsiders and the Polish witnesses, at least, had no reason to break this taboo" 295 .

It is worth adding that memory of score-settling and summary reprisals endured until the end of the eighties. Danuta and Aleksander Wroniszewski noted the death of the wife of Marian Karolak, who was mayor of Jedwabne on 23 June 1941 and, according to historians, initiated and led the massacre. However, he never stood trial because he disappeared after the war and was never heard of again. As the Wroniszewskis write: "The older children fled to Warsaw; his wife stayed in Jedwabne with the youngest child. Revenge was taken on her instead. As she lay, murdered, in the street, the infant was still squirming around on her, sucking at her breast... No one searched for the perpetrators of that crime"296. It is not known who took revenge on Karolak by killing his wife and why they did this. It can only be assumed that his collaboration with the Germans in itself provided the motive. The fact that he left Jedwabne after the war, leaving his whole

293 Persak, “Akta postępowań cywilnych z lat 1947-1949”, p. 378.

294 Quotation after Persak, “Akta postępowań cywilnych z lat 1947-1949”, p. 378.

295 Persak, “Akta postępowań cywilnych z lat 1947-1949”, p. 378.

296 The Wroniszewskis. “....aby żyć”, p. 8. 
family behind, shows that his relations with some of the local residents must have been strained.

The situation was complicated further shortly after the war by the cases relating to the deceased Jewish inhabitants of Jedwabne that came before the magistrates' court in Łomża from 1947 to 1949 under the decree of 8 March 1946 on the legal appropriation of property that had either been abandoned or was once owned by Germans. Since the winners of such cases stood to gain abandoned property, a group of profiteers appeared that sought to exploit the situation. The case files contain a number of testimonies that show how attempts were made to manipulate information and above all, to use the argument that the Germans had perpetrated the massacre of the Jews in Jedwabne to take ownership of the homes that had belonged to the murder victims. Two years of court cases and the arguments and conflicts surrounding the former Jewish properties certainly influenced the manner in which the Jedwabnians perceived the event itself. In the 1980s, the Wroniszewskis recorded the following testimony from a woman who was then seventy years old: "Thirty Jewish families once lived here where four brick villas stand today"297.

During the course of the 1949 investigation, the fullest clarification was given by Julia Sokołowska, who was working on the day of the massacre as a cook for the military police. Sokołowska listed by first name and surname seventeen people who allegedly participated in the pogrom and also revealed that it was the native Poles who murdered the Jews rather than the Germans, who only photographed the whole incident ${ }^{298}$. According to the findings of Krzysztof Persak, who analyzed all the case files, between one and two hundred people took part in the massacre ${ }^{299}$ (Persak 2002: 421).

The families and neighbors of those arrested in connection with the Jedwabne murder case provided them with alibis and several dozen of them also signed letters. According to Krzysztof Persak, this shows that Jedwabne's residents were highly mobilized in defense of those who had been detained ${ }^{300}$. A bill of indictment was issued on 31 March 1949. It listed the surnames of 22 people suspected

297 The Wroniszewskis. “....aby żyć”,., p. 9.

298 Persak, “Akta procesu z 1949 roku”, p. 463-465; Andrzej Rzepliński, “Ten jest z ojczyzny mojej? Sprawy karne oskarżonych o wymordowanie Żydów w Jedwabnem w świetle zasady rzetelnego procesu”. In: Wokół Jedwabnego. Vol. 1. Studia, eds. Paweł Machcewicz and Krzysztof Persak. Warsaw: Instytut Pamięci Narodowej, 2002, pp. 353-459.

299 Persak, "Akta procesu z 1949 roku”, p. 421.

300 Persak, "Akta procesu z 1949 roku”, p. 426. 
of being involved in a crime against the Jewish population in Jedwabne. Krzysztof Persak concluded from an investigation he undertook of these people's identities and their biographies that the suspects did not belong to the margins of society. Most of them were ordinary citizens. They varied in age from 19 and 22 (the Laudański brothers) to 52, with a mean age of 40 . The majority came from Jedwabne, were married with children and poorly educated ${ }^{301}$. It is worth adding that Bolesław Ramotowski, Roman Górski, and Franciszek Łojewski revealed in 1947 that they had served in the Home Army.

As mentioned above, on 17 May 1949, the court convicted twelve and acquitted ten of the defendant ${ }^{302}$. Paweł Machcewicz writes that if these trials had been held in a democratic country with full media access, they certainly would have been widely commented on and reported across the media, becoming an important event in the life of the community, much like similar trials of the time. Poland was not, however, democratic, so debate and research relating to "the most sensitive episodes in the German occupation and Polish-Jewish relations" got off to a late start ${ }^{303}$. Machcewicz is thinking here of the national debate because throughout the People's Republic, trials involving those accused of complicity in the massacre of Jedwabne's Jews were nothing out of the ordinary for Jedwabne's inhabitants.

In his analysis of the case files relating to the crime committed against Jedwabne's Jewish population, Krzysztof Persak focuses on proving the unreliability of the investigations conducted by the prosecuting attorneys. His extensive analysis incorporated the case files of the 1949 trial and the 1953 trial of Józef Sabuta as well as the files of the criminal trials conducted between 1967 and 1974 by the District Commission for the Investigation of Nazi Crimes in Białystok. He also shows how the witnesses themselves from trial to trial or even within single trials gave contradictory statements relating to the indictment of others. One of these regular witnesses who attended every trial was Józef Grądowski, who was rescued from the pogrom of the Jews. As Krzysztof Persak shows, Józef Grądowski had to testify under enormous pressure from the community. The testimony he gave in the criminal proceedings of 1949 favored some of the accused and he also "signed petitions in their defense". However, in Sobuta's trial, he was a witness for the prosecution ${ }^{304}$. He also testified during investigation

301 Persak, "Akta procesu z 1949 roku”, p. 428.

302 Persak, "Akta procesu z 1949 roku", p. 429.

303 Machcewicz, “Wokół Jedwabnego”, p. 15.

304 Persak, "Akta procesu z 1953 roku Józefa Sobuty”, p. 721. 
proceedings initiated on 27 May 1967, making the following accusation against Antoni Grzymała: "Around 8 in the morning, I received a visit from Feliks Żyluk, Antoni Surowiecki and Grzymała, who told me to leave my apartment and head to the market square in Jedwabne to get to work weeding the grass. I calculated that they could drag me out by force, so I went voluntarily. They had iron bars and wooden clubs and I was afraid that they could beat me if I didn't go voluntarily" ${ }^{305}$. However, in his next testimony, which he gave before the County Court in Łomża in November the same year, Grądowski testified as follows: "When we turned up at the market square, all the men were separated from the women and children and then the men were led out of the town to Śleszyński's barn. I didn't go to this barn because the Poles, Feliks Żyluk and Antoni Surowiecki (....) and Grzynała, whose first name I don't recall, but he currently lives by the mill, took me, my wife and the children and hid us in Żyluk's home"306. Persak concludes from his analysis of Grądowski's testimonies that the defendants pressurized him into changing them. Given that Grądowski stayed in Jedwabne after the war, a period during which he was called upon to testify ten times at various criminal trials, Persak claims that "he must have therefore yielded to pressure from the local community" ${ }^{307}$. When the Wroniszewskis spoke to Grądowski's wife at the end of the 1980s, she recalled:

My husband was very pious and that is probably the only reason why he humbly bore various insults. In the night, we continuously heard gunshots of some kind or other and banging at the door. We never opened it. Felek $\dot{Z}$ moved out after a time to the Recovered Territories, ${ }^{308}$ because his family had grown in size (...). When he was visiting family, he learned of my husband's death. He came by my home, resentfully demanding to know why I hadn't informed him about the funeral. That was the last straw. "Józef would have turned in his grave if I'd done that." And now Felek is also in the cemetery, this is my time, and no one will be reminding me of old injustices and grievances ${ }^{309}$.

This statement recorded over forty years after the massacre perfectly conveys the tension under which witnesses to the events and the entire town lived for all those years.

305 Testimony cited after Persak, “Akta śledztwa z lat 1967-1974”, p. 829.

306 Persak, "Akta śledztwa z lat 1967-1974", p. 839.

307 Persak, "Akta śledztwa z lat 1967-1974", p. 819.

308 The Recovered Territories was the term used by the Polish People's Republic authorities to describe post-German lands annexed to Poland after the Second World War. The term "recovered" was used to underline that these lands had once historically belonged to Poland.

309 Wroniszewskis. “...aby żyć”, p. 9. 
Other witnesses yielded to the same pressure from the local community, including Julia Sokołowska, who had been working in 1941 as a cook at the military police station. As previously mentioned, she listed the surnames of 17 alleged perpetrators of the Jedwabne massacre under interrogation in 1949. However, during the court case, as Persak writes, "possibly under pressure from the families of the people she had accused, she was the only witness to present a version [of events] in which 68 Gestapo officers arrived in the town"310. In 1974, she added more Germans to this total in her testimony ${ }^{311}$. Other witnesses gave similarly confusing evidence. Finally, in 1974, all the cases were dismissed and no one was convicted on the grounds that the alleged perpetrators and the German military policemen were living outside Poland ${ }^{312}$. As Krzysztof Persak writes, the prosecutor leading the final investigation, Waldemar Monikiewicz, deliberately accused the Germans of committing the massacre in Jedwabne and sought confirmation of this in the evidentiary material, often manipulating it in the process. As Persak explains, the political situation in Poland changed after March $1968^{313}$ and "prosecuting Poles for crimes committed against fellow Jewish citizens was unthinkable, especially when these had been perpetrated in cooperation with the Germans" 314 . However, it is worth considering whether the Jedwabnians who had once again been summoned before a court after the war to testify in relation to this case were actually aware of the changing political climate in the late 1960s.

None of the available sources are able to provide us with an unequivocal response to this question. However, from the Jedwabnians' perspective, it would seem to be important that for many years, criminal cases were being brought against the town's residents and accusations being put forward against one person after another. The fact that twelve of the accused were convicted also had

310 Persak, "Akta procesu z 1949 roku”, p. 429.

311 Persak, “Akta śledztwa $z$ lat 1967-1974”, p. 822.

312 Persak, “Akta śledztwa z lat 1967-1974”, p. 823.

313 "March 1968", as it is known in Poland, was a complex political crisis involving mass protests by students and intellectuals against the Polish People's Republic and the government's campaign of aggressive anti-Semitism. The crisis resulted in the suppression of student strikes by security forces and the mass emigration of Polish Jews, who were forced to leave the country on one-way passports, as well as intellectuals who could not see themselves gaining any further opportunities while living in Poland (cf. Wawrzyniak, Veterans, Victims, and Memory, pp. 196-211). For the campaign of anti-Semitism, see Darius Stola's article "The Anti-Zionist Campaign in Poland 1967-1968”, available online at http://web.ceu.hu/jewishstudies/pdf/02_stola.pdf, (last accessed 9 Jan. 2018).

314 Persak, “Akta śledztwa z lat 1967-1974”, p. 823. 
a bearing on the life of the community since their families had to cope without their help while they served out their sentences. After being released, some of those who had been convicted returned to live in Jedwabne, living in homes that had once belonged to their victims, near to the scene of the crime and those who had testified against or defended them during the trial. It is difficult to tell from the documents we have today how they spoke amongst themselves about the crime. The statements recorded by the Wroniszewskis and Agnieszka Arnold in her Neighbors film only show fragmentary evidence of the tension, conflicts, and pressures that had existed within the community.

The situation was further complicated by the fact that in 1961, on the twentieth anniversary of the crime, the first memory marker commemorating Jedwabne's Jews was erected at the scene of the crime. It should be emphasized that this was several years before the March 1968 political crisis and the resulting change in the political climate that had such an impact on the Jews in Poland. The memorial was erected in response to the national memory policy at the end of the fifties and beginning of the sixties. This was beginning to ever more forcefully emphasize the significance of the wartime suffering of the civilian population. At the time, as Joanna Wawrzyniak writes, "The martyrdom of the village, towns and cities and even entire regions was emphasized" 315 . A distinctive feature of this period of remembrance was a tendency not to separate the fates of the Jewish Poles from those of the non-Jewish Poles, which, according to Wawrzyniak, contributed to a vision, prevalent at the time, of a progressive Polish nation ${ }^{316}$. The existing political climate, further mediated by the local press, must have filtered down to the local community and influenced the way it remembered the Jews.

We were not able to find any documents indicating how the Jedwabnians reacted to the memorial built on the twentieth anniversary of the crime or who instigated its construction, what motivations dictated the need to build such a memorial, what form the unveiling ceremony took or who attended this ceremony. Nevertheless, it is known that it was immediately added to the official lists of sites of memory devoted to the martyrdom of the Polish nation ${ }^{317}$. As Kurkowska-Budzan ${ }^{318}$ writes, young people visited the memorial because it was excellently suited to the communist ideology of the day and soon become part

315 Wawrzyniak, Veterans, Victims, and Memory, p. 197.

316 Wawrzyniak, Veterans, Victims, and Memory, p. 199.

317 Przewodnik po upamiętnionych miejscach walk i męczeństwa: lata wojny 1939-1945. Warsaw: Wydawnictwo Sport i Turystyka, 1964.

318 Kurkowska-Budzan, "Jedwabne and Wizna" 
of a network of sites of memory devoted to the martyrdom of the Polish nation during the Second World War. Although it was written on the memorial that it marked the site where the Jewish population had been slaughtered, this did not prevent anyone, whether they were visitors or members of the local community, from approaching it to honor the memory of "our suffering". Even when the political system changed in 1989, the memorial retained its significance. All the people we spoke to in 2016 assured us that it was still a very important site of memory for them.

Kurkowska-Budzan, who spoke with Jedwabne's residents in the late 1990s about their lives before the war and relations with the Jews, concluded that they experienced the sensation from the day of the crime that "the devil had taken up residence in the town" and subsequently perceived every tragedy, especially when someone met a sudden death, as divine retribution. This researcher provides evidence that the Jedwabnians believed that God expected them to atone for their sins by citing a story about a female employee of the municipal waste disposal company who prevented a lawn that had grown over the sidewalk from being trimmed because the grass had formed into the shape of a cross. This was the place where a young Jewish woman with a child in her arms had died. As Kurkowska-Budzan wrote, "people regarded this as a miracle - a sign from God addressed to Jedwabne's sinners - so they gathered together and prayed"319.

Kurkowska-Budzan writes that despite the passage of time, the local residents still recall enjoying themselves with the Jews in their club and their neighbors getting married. Many of them also remember Yiddish words and songs. She goes on to write that she realized at one point that "my interviewees had in a sense lost part of their lives. This lost world was also 'their' world" ${ }^{320}$. KurkowskaBudzan's interviewees also stated without being prompted that "they miss 'something' they have lost" 321 while also being unable to free themselves from traumatic memories of the day of the murder ${ }^{322}$.

The Wroniszewskis' article, Marta Kurkowska-Budzan's texts, and Agnieszka Arnold's Neighbors demonstrate how Jedwabne's inhabitants were speaking about the crime a year before the debate. Some of the statements they contain clearly demonstrate that at least some of the inhabitants were experiencing remorse and

319 Kurkowska-Budzan, "My Jedwabne”, p. 205.

320 Kurkowska-Budzan, "My Jedwabne”, p. 203.

321 Kurkowska-Budzan, "My Jedwabne”, p. 204.

322 See testimonies in Arnold's Neighbors documentary, 2001. 
were unable to free themselves from pervasive images of the day of the massacre. One of the female residents ${ }^{323}$ commented as follows on camera: "they decapitated a young child and played with the head like a ball. Oh, dear God! (sighs) One has to have a conscience of some kind or other. What was this child guilty of? Take him, cut off his head and play with it like a ball. Anyway, I don't know. Maybe an eviler executioner is needed [in such cases]. If a German had done it, it would make little difference, [the same] if a Russian had done it, but a Pole?". The same woman continued: "Of course... that cry returns... again and again ... Just as one's sitting calmly and there's no one around, that cry... One has to have a conscience. Apparently, they went to church, they prayed; why continue to go to church [only] to offend God?"324

Another person interviewed in the film, a man, commented:

There are so many typical names (...) that it's difficult to say who it was. Young people with sticks. I wouldn't call them sticks, more like clubs, something of the sort, kind of thick. Anyway, the column [of Jews] looked resigned (long pause). The age varied from young children to the elderly (long pause). What I remember as I passed the column on Piękna Street were the objects lying there, small hoes that were most probably used to weed the grass, forks, spoons, the occasional shoe and... (pause). I have lived with this image for sixty years (waving his finger to signal disagreement), for fifty-nine ${ }^{325}$.

Marta Kurkowska-Budzan also recorded a statement given by a woman who had a Jewish woman as a neighbor and even attended her wedding. When she went to the barn two days after the pogrom, she saw her dead body and those of her children lying in the corner of the burnt-out barn. Having seen this, she was unable to speak for several days. Kurkowska-Budzan writes: "Recounting this to me, Natalia seemed to see it just in front of her" ${ }^{\prime 22}$.

Agnieszka Arnold's documentary contains statements that show that some of the residents made an attempt to comprehend the reasons for what had happened and wanted to work through the past. Janusz Dziedzic commented as follows on camera: "And this should be made crystal clear. There's no getting out of this. We apologize to you because we destroyed you. Just as we demand apologies from the Nazis, just as we demand apologies from the Russkis, let us also apologize. It's not only Jedwabne. We need to talk about everything, everything

323 The voices of some of the people in the films have been disguised, while the voices of others, who show their faces, remain unaltered. There are also people who do not show their faces.

324 Citation taken from Agnieszka Arnold's Neighbors, 2001.

325 Citation taken from Agnieszka Arnold's Neighbors, 2001.

326 Kurkowska-Budzan, "My Jedwabne”, p. 204. 
that happened. The truth is disagreeable and painful, but the truth needs to be told so that [future] generations remember. For telling the truth is the only way of preserving peace in the world".

Marta Kukowska-Budzan concludes from her analysis of her interviewees' statements that the manner in which Jedwabne's inhabitants spoke about the mass murder many years later was notable for its photographic precision, which proves that this, for them, was a traumatic event that "cannot be forgotten and cannot be remembered" 327 . Similarly, the witnesses speaking in front of Agnieszka Arnold's camera take long pauses, gesticulate, shake their heads and shrug their shoulders as they speak. The shrugging of shoulders, apparent lack of emotion and statements that contain nothing but description "mark a point between witness and testimony that can be seen as a moment of trauma, a moment in which the historical real and the memory of it as demanded by the imperative to testify to it disintegrate and present for the witness and the interviewer (...) a break" ${ }^{\prime \prime 28}$. This "break" is extremely important because it shows the presence of trauma which is impossible to express in words ${ }^{329}$. The way the inhabitants of Jedwabne were describing the massacre of Jews before 2000 shows that it was a kind of traumatic, undomesticated history ${ }^{330}$.

\section{Jedwabne from 2000 to 2001}

There is a rich literature, some of it composed in English, ${ }^{331}$ devoted to the causes and trajectory of the Polish debate as well as its dynamics and the arguments evoked as it progressed. We shall therefore, focus in this part of the chapter on

327 Kurkowska-Budzan, "My Jedwabne”, p. 202.

328 Michael Bernard-Donals and Richard Glejzer, "Between Witness and Testimony: Survivor Narratives and the Shoah." College Literature, Vol. 27, No. 2, 2000, p. 2.

329 Cathy Caruth, Unclaimed Experience. Trauma, Narrative and History. Baltimore: Johns Hopkins University Press, 1995.

330 Kurkowska-Budzan, "My Jedwabne", p. 202.

331 Törnquist-Plewa, "The Jedwabne Killings"; Wolentarska-Ochman, "Collective Remembrance in Jedwabne"; articles devoted to Tomasz Gross's book, the Jedwabne massacre, the meaning of this event and the Polish debate revolving around Jedwabne have been, published in such journals as the Slavic Review (61 [3]: 2002), Polish Sociological Review (1 [137]: 2002), East European Politics and Societies (16 [1] 2002), Holocaust and Genocide Studies (17 [1]: 2003), POLIN: Studies in Polish Jewry (15: 2002). 
showing how the debate was received by the Jedwabnians and how it influenced their memory of the crime that had been committed. However, it is worth mentioning that few historians or journalists actually visited the town in person. The debate proceeded outside the object of its reflection, as it were, even though it was referring very realistically both to the town and the biographies and attitudes of real people living in Jedwabne.

In his book Neighbors, Jan Tomasz Gross writes: "Usually the canon of collective identity is assembled from deeds that are somehow special, striking, or remarkable. It is made up, in other words, of actions that depart from routine, that are unusual. And even though it is only a Fryderyk, a Jan, or a Mikołaj who has actually performed such deeds, as constitutive components of the canon they also belong to the collective 'us'" "332. According to this line of reasoning, the Polish musical establishment "is proud of 'our' Chopin; Polish science of 'our' Copernicus; and Poland thinks of itself as a 'bastion of Christianity' [przedmurze chrześcijaństwa] in no small part because King Jan Sobieski defeated the Turks in an important battle near Vienna. For this reason, we are entitled to ask whether the deeds committed by the likes of Laudański and Karolak - since they were so striking and unusual - engage Polish collective identity as well" ${ }^{\prime 33}$. Generalizations of this type led to the debate on Jedwabne transcending the conceptual framework of a discussion on the wartime experiences of a small town in Podlasie to such an extent that it became a reflection on Polish national identity.

These words acquired a completely different sense and meaning in Jedwabne, where Laudański, rather than being a symbolic figure representing a certain type of attitude, is a neighbor, uncle, father-in-law, and cousin ${ }^{334}$. The town of Jedwabne is very real, possessing a long history, a church dating from 1935, a manorial complex that once belonged to the Rembieliński family, a historical market square and, above all, real inhabitants, who, although the debate has abated, not only have to live with the memory of a crime committed by their ancestors that is yet to be worked through, but also in the shadow of the symbol their small motherland became in 2001. One of the town's residents made the following comment in an interview: "Now Jedwabne goes under the banner of ' 41 and Jedwabne is only viewed through the prism of these events. They're even creating a promotion, making something, phoning wherever, whether it's for some postage stamp or postcard; there's even an ink stamp. Aaaah, that's Jedwabne, but whatever it is we're doing has a subtext, don't you think? And I suspect that

332 Gross, Neighbors, p. 136.

333 Gross, Neighbors, p. 136.

334 Kurkowska-Budzan, "My Jedwabne"; Kurkowska-Budzan, "Imaging Jedwabne”. 
Jedwabne has been branded like this and this is unlikely to ever change now" (F, ca. 35 years old, Jedwabne, August 2016).

As one local resident stresses, in 2001, a community that had never before had any role to play in the history of the nation, a community whose life had been guided by its own rhythms and problems, suddenly, due to the arrival of the sixtieth anniversary of the massacre, found itself at the very center of Grand History: "nothing of the kind had happened, no battle or other historical event that would have made some difference (...); this place had experienced nothing of the kind..." (M, ca. 60 years old, Jedwabne, June 2016). The erection of the new memorial by the Polish state and the remembrance ceremonies involving the President of the Republic of Poland, Aleksander Kwaśniewski, were events that historicized the life of this small town in Łomża County. To use the language of Pierre Nora, a traditional, small-town community had been cut off from its milieu of memory and inserted into the axis of history, which was rapidly gathering momentum in late 2000 and early $2001^{335}$.

As was mentioned earlier, researchers such as Marta Kurkowska-Budzan and Agnieszka Arnold did actually go to Jedwabne to speak with the local residents in person and observe the process that was transforming their attitudes. Both of these researchers showed that no matter how difficult it was for them, many Jedwabnians wanted to speak about what had happened in 1941. As Agnieszka Arnold wrote: "Such knowledge needs to be shared, these people need to be heard out, but during the PRL [Polish People's Republic], neither the party nor the Church nor anyone else wanted to listen to them. These people grew up with this memory. It accompanied them every evening. Every day, for 60 years, they woke up with it. These people's mentality was determined by that crime"336. Arnold's documentary proves that once sixty years had passed since the crime was committed and the political system had changed, Jedwabne's inhabitants became ready to talk and reflect on what they had done.

The witness statements recorded by Agnieszka Arnold and Marta KurkowskaBudzan reveal these witnesses' trauma. These people are unable to free themselves of the cries of the burning victims and the stench of their charred bodies. Arnold's documentary is shocking because it reveals how people were beginning

335 Pierre Nora, “Czas Pamięci”" Respublika Nowa, Vol. 7, No. 153, 2007, pp. 37-43.

336 Sebastian Matuszewski, “Ogarnął mnie Strach” (I Was Gripped by Fear), an interview with Agnieszka Arnold, Tygodnik Przeglą, 20 Jan. 2008. Retrieved from: https://www. tygodnikprzeglad.pl/ogarnal-mnie-strach/ (last accessed 5 June 2018). 
to openly speak about what had happened 60 years after their collective silence ${ }^{337}$. The town began to seek assistance with working through its traumatic past from outsiders, in particular, a director, a journalist and a researcher. However, the situation rapidly changed. When Anna Bikont, a journalist working for the Gazeta Wyborcza newspaper, visited Jedwabne not long after the publication of Gross's book she did in fact draw attention to the readiness of some people to talk, but her primary observation was that they were gripped by nervousness and fear before doing $\mathrm{so}^{338}$. As the national debate swelled, transforming Jedwabne into a symbol of Polish anti-Semitism, the Jedwabnians began to react defensively. They became reluctant to talk, a community organization called the Committee to Protect the Good Name of the Town of Jedwabne appeared in the town and those who had been giving interviews to the press began to be stigmatized and branded traitors to the good name of the town and that of the Polish nation.

In their texts from this period, Anna Bikont, Joanna Tokarska-Bakir, and Marta Kurkowska-Budzan reveal how the Jedwabnians' nascent reluctance was projected onto a number of local residents including the former mayor Krzysztof Godlewski and the Dziedzic family, who were accused of blackening the name of Jedwabne and that of Poland. However, the main target of the Jedwabnians' aversion was the plans for the national monument commemorating the massacre that was to be erected on the sixtieth anniversary of the crime. Joanna TokarskaBakir, who viewed these events with regret, claimed that the town's history had come full circle, as Jedwabne "once again performed a self-purification"339. The Jedwabnians who wanted the memory of the Jewish residents of their town murdered by their neighbors on 10 July 1941 to become a component of Jedwabne's collective memory and for the local community to commemorate the victims in a dignified manner had either emigrated from Jedwabne or died. But had the town's history, as Tokarska-Bakir, claims, really come full circle?

Those revisiting Jedwabne today cannot help but notice that the memory landscape has undergone a radical transformation since 2000 when Bikont visited the town for the first time. In 2000, the town was essentially lacking in any permanent repositories of memory or monuments that would confer meaning on the past. To use Alexander Etkind's terminology, the Jedwabnians' memory was "soft" at this time, that is, it exclusively functioned within the world of oral

337 Janina Parandowska, "Liczenie szkieletów” (Counting the Skeletons). Agnieszka Arnold, director of the film Neighbors, Polityka, 15/2001.

338 Bikont, The Crime and the Silence.

339 Joanna Tokarska-Bakir, Rzeczy mgliste. Sejny: Fundacja Pogranicze, 2004. 
transmission ${ }^{340}$. Moreover, in 2000, Jedwabne was continuously grappling with problems provoked by the post-communist political transformation ${ }^{341}$. After 2001, when the Jedwabnians sensed that people from the outside were beginning to compel them to show remorse and repent, they decided to undertake various activities aimed at the construction of an alternative narrative of their common past. In this sense, the local history had not really come full circle because the situation in the new millennium differed greatly from that in 1941, when the Jedwabnians did not know how to cope with the crime that had been committed so decided to keep silent about it. In 2001 they started to implement a kind of "monument-therapy".

When, in 2010, we visited Jedwabne for the first time, we gained the irresistible impression that the Jedwabnians were actually attempting to erase the past by enshrouding the crime that had been committed in their own suffering, transforming Jedwabne into a Polish domain of martyrdom ${ }^{342}$. For example, they had planted a huge cross - a monument commemorating those who had been deported to and murdered in the East - in the park overlooking the Main Market Square; and the walls of the parish church of St James the Apostle were bedecked with images of the Łomża region's blesseds: the Blessed Marianna Biernacka, who gave up her life for her daughter-in-law, the Blessed Father Michał Piaszczyński, who shared his bread with a Jew while he was being held at the Sachsenhausen (Oranienburg) camp and the Blessed Father Adam Biergielski, who went into German captivity in place of his local, eighty-year-old parish priest and died at Dachau as a "silent and imperceptible hero"343. The church also contained portraits of other hallowed Poles, notably the Polish pope, John Paul II, Stefan Wyszyński, who was Primate of Poland from 1948 to 1981, and the Blessed Father Jerzy Popiełuszko, who was murdered in 1984 by the security service of the Ministry of Internal Affairs. In 2011, these portraits were joined by a plaque commemorating those who had been deported to Siberia. Another important space of memory is the municipal cemetery. In front of the cemetery, a memorial to victims of the NKVD, Nazis and Stalinist UB (Office of Security) murdered between 1939 and 1956 has been erected (Fig. 3.2), and in the cemetery itself, there are the graves of

340 Aleksander Etkind, Warped mourning. Stories of the Undead in the Land of the Unburied. Stanford: Stanford University Press, 2013.

341 Bikont, The Crime and the Silence;

342 Lech M. Nijakowski, Domeny symboliczne: Konflikty narodowe i etniczne w wymiarze symbolicznym. Warsaw: Wydawnictwo Naukowe Scholar, 2006.

343 Sourced from the diocese of Łomża's website: http://www.diecezja.lomza.pl/diecezja/ blogoslawieni/bl-ks-adam-bargielski (last accessed 15 September 2016). 
AK soldiers and a Tomb of the Unknown Soldier (Fig. 3.5), by which a red and white flag waves on a high mast for 12 months of the year.

All these memory markers give the impression that Jedwabne's inhabitants erected them and devised the memory rituals revolving around them to counterbalance the Jewish memorial and neutralize its negative connotations by drawing attention to positive moments in the town's history. However, when, in 2016, we were conducting our research in Jedwabne devoted to the meaning of its monuments, we began to wonder when we were evaluating the Jedwabnians' attitude to their own past, whether we were misinterpreting the social function of the monuments erected by the local residents.

\section{The Jedwabnians as a Parish Community}

We observed during our research that everyday life within the Jedwabnian community is largely shaped by communal participation in the life of the parish. Furthermore, the pious Jedwabnians utilize many folkloric forms when interpreting reality. This type of religiosity is particularly notable for its powerful ritualization and the faith that is shown in the efficacy of certain symbolic acts $^{344}$. Such acts include the local population's penchant for erecting roadside shrines and crosses or asking for God's favor by making regular donations toward renovations to the church. One of our female interviews commented as follows: "For example, that Jude the Apostle, we made it. My husband was lying in hospital, almost dying, and I said (...) 'if he recovers, we'll make an altar.' (...) and we build this altar [dedicated to Jude the Apostle]. People come here to pray now" (F, 82 years old, Jedwabne, June 2016).

This traditional community has its authorities, the most prominent being the priest, who is not only God's anointed, which grants him a higher status, but also knows all the inhabitants better than anyone else (since they confess their sins to him), has an excellent knowledge of the systems in place in the countryside and is always able to offer his flock suitable advice on how they may avoid taking actions that contravene these systems. One of the female Sybiraks, ${ }^{345}$ who came up with the idea of placing a commemorative plaque in the local church recalls: "I was saying that I would sponsor it, but the priest said (...) 'if you pay,

344 Cf. Anna Niedźwiedź, The Image and the Figure: Our Lady of Częstochowa in Polish Culture and Popular Religion. Kraków: Jagiellonian University Press, 2010.

345 The term "Sybirak" is commonly used to described those who were deported into the Asian part of Russia during both the Russian Empire (from the eighteenth to the twentieth century) and the Soviet occupation (1940-1941). 
everyone will say that you made this plaque for your family' The priest then took it upon himself to sponsor the plaque himself. And now we have this plaque" (F, 76 years old, Jedwabne, June 2016).

The priest therefore tends to his parish community's memory and he is the one who often encourages members of his flock to tend to national memory, thereby situating his congregation within a wider context. As one female resident recalled, "it is in fact the priest, the dean, who takes great care to ensure that patriotic values are developed, and the initiative always comes from him, so maybe you've done something, maybe at the church, maybe the youngsters have prepared something and you always know; that's so precious" (F, ca. 50 years old, Jedwabne, June 2016).

The priest also exerts a very real influence on his parishioners' lives, which enables him to hold sway over the community and keep them within the religious milieu. As we learned during one of our more informal conversations with Jedwabne's inhabitants, if anyone misses Mass and fails to sign the attendance register, the priest can refuse, when they die, to take their body from their home to the church (this only applies to the moving of the body, not the burial itself). As a result, as one of our female interviewees underlines, "once a tendency for empty pews began - not anymore" (F, ca. 35 years old, Jedwabne, August 2016). The very existence of a bond of such strength between the community and church and the frequent evocation of religious notions to explain everyday life events have led to the meaning of events from the past being sought in such religious notions as well.

This process began to overlap with the local community's memory of the Jews, as evidenced by the materials Marta Kurkowska-Budzan collected in Jedwabne that we quoted from above. Unable to forget about the Jews, the local residents began to incorporate their memory of their Jewish neighbors into their own religion-based conceptual memory framework. This may explain why it was at the site where the young Jewish woman carrying a child was murdered that an employee of the municipal waste disposal company saw a cross. Ewa WolentarskaOchman interprets local vernacular practice of this nature as follows: "These two memory sites, with their mythologized narratives of events, enabled the community to express collectively what could only be acknowledged privately. By locating the tragedy in the Christian narrative tradition of the sinful man and punishment by God, the Jedwabnians could work through the tragedy and the two sites could accommodate the community's feelings of guilt and contrition"346.

346 Ewa Wolentarska-Ochman, “Collective Remembrance in Jedwabne”, p. 173. Sławomir Kapralski opposed such an interpretation, claiming that the way the Jedwabnians 
The manner in which memory of the Jews was beginning to function in Jedwabne before 2001 was reminiscent of the manner in which other tragic events function in communities characterized by religiosity imbued with elements of folklore. In such communities, the committing of a misdemeanor or crime is perceived as a sin to be atoned for. This explains the tradition of erecting penitential crosses at sites where crimes have been committed to relieve and cleanse collective guilt ${ }^{347}$; or the belief that such sites are particularly dangerous and need to be marked with a religious sign, so their negative influence can be neutralized through the power of prayer; or the common ritual of going in procession to a particular site on All Souls' Day to say prayers $^{348}$. It is worth mentioning at this juncture that it was in fact on the First of November, that is, All Souls' Day, that the Jedwabnians used, until 2000 , to lay burning candles by the memorial erected at the place where the burning barn had once stood.

Both folkloric religiosity and religious memory as a whole are characterized by a desire to seek parallels and explain existing situations by referring to a foundational event of fundamental importance to the religion in question. In the case of Catholics, this event is the life of Jesus Christ. Such an approach toward the explanation of a traumatic past event is evident in the homily delivered by Bishop Stanisław Stefanek at Jedwabne's local church on 11 March 2001, which also happened to be the culminating moment of the debate on Jedwabne ${ }^{349}$. The bishop began his homily with the following words:

commemorated Jews is a kind of forgetting and expulsion rather than local remembrance. Sławomir Kapralski, “The Jedwabne Village Green? The Memory and CounterMemory of Crime." History and Memory, 2006, No. 1, p. 182; compare Sendyka, "Niepamięć albo o sytuowaniu", p. 262.

347 Jan Adamowski, “Motywacje stawiania krzyży i kapliczek przydrożnych.” In: Krzyże i kapliczki przydrożne jako znaki społecznej, kulturowej i religijnej pamięci, eds. Jan Adamowski, Marta Wójcicka. Lublin: Wydawnictwo Uniwersytetu Marii CurieSkłodowskiej, 2011, pp. 34-35.

348 Agnieszka Pieńczak, "Wybrane kapliczki i krzyże przydrożne jako pomniki pamięci w krajobrazie kulturowym Śląska Cieszyńskiego.” In: Krzyże i kapliczki przydrożne jako znaki społecznej, kulturowej i religijnej pamięci, eds. Jan Adamowski and Marta Wójcicka. Lublin: Wydawnictwo Uniwersytetu Marii Curie-Skłodowskiej, 2011, p. 160.

349 Stanisław Stefanek is the Bishop of Łomża and participated in a Mass in Jedwabne to support local residents. He also met the Committee to Protect the Good Name of the Town of Jedwabne. 
Dearest in the Lord! The liturgy for the Second Sunday of Lent invites us to Mount Tabor, to the Mount of Transfiguration and bids us farewell after this deeply mystical experience with the following command: 'This is My beloved son, listen to him.' With this command we would also like to walk away today after experiencing the High Mass, after singing the Lenten Lamentations. Today we have a special commentary on Mount Tabor: it is coming to an end at this moment in Rome, in St Peter's Square, at a time when the Holy Father has raised 238 martyrs to the glory of the altar (...). We will remember this fact because it is not only an event of the most recent days of the Universal Church, but also the fulfilment of the deliberations that the holy liturgy outlines for us. There is also a social context to our meeting, which is being experienced by us all and by many inhabitants of our Motherland: the unprecedented attack on Jedwabne ${ }^{350}$.

In the first words of his homily, the bishop is domesticating Jedwabne's history by setting it within the broader context of events from the life of Christ and the history of the Universal Church. Rather than immediately consoling the Jedwabnians, the homily begins by reminding them of events that took place two thousand years ago on Mount Tabor and later became an important component of the religious memory of all Christians. Next, the Jedwabnians who have been accused of murder are advised of the need to remember the martyrs murdered during the war who happen to have just been canonized by the Universal Church. Only now do the recollection of events from Christ's life and explanation of their meaning become a starting point for reflecting on Jedwabne's history and interpreting current events.

After this opening statement, the bishop attempted to help the congregation understand what had happened on 10 July 1941 by speaking of a "history of love and hate, heroism and bestiality" which had led in the twentieth century to the murdering of "innocent people in Jedwabne, Katyn, Dachau, Auschwitz, (...) Rwanda, the Balkans, (...) and Palestine". He went on to stress that "the martyr, irrespective of what nation he comes from or what religion he belongs to, is a martyr of hatred" 351 . He did not condemn the murdered Jews, claiming instead that they were "our brothers" 352 . At the same time, however, he repeated some stereotypes about Jews that suggests that Jews sometimes invent accusations against others to achieve their goals. He also drew attention to the fact that even though it was Berlin and Moscow that had unleashed Nazism and Bolshevism on the world, nobody had accused these cities' inhabitants of the crimes that had been committed in the name of these ideologies. He went on to stress: "We

350 Stanisław Stefanek, "Miłość buduje historię", Ziemia Łomżyńska, 2001, No. 6, p. 433.

351 Stefanek, "Miłość buduje historię", p. 434.

352 Stefanek, "Miłość buduje historię", p. 435. 
have learned to understand history more profoundly and never oversimplify matters by associating with a nation, name or city ideologies that came from the fathers of all evil". The bishop used many parables in his homily that were meant to help the Jedwabnians to understand the ensuing situation. He spoke about Golgotha, which "has accompanied the Church for many centuries". Finally, he stressed that Jedwabne was "a place where consciences are molded and a school for characters and the creation of a new society. This is Jedwabne's future, this is Poland's future and this is the future of all places where people suffer in innocence" 353 .

Anna Bikont, who listened to the homily and learnt how the representatives of the Good Name committee welcomed the bishop stated that "Jedwabne has become a training ground for extremist nationalist groups" (Bikont 2015: 136). In his homily, the bishop attempted to reveal parallels to the local residents between the events of 1941 and 2001 by reminding the congregation that the evil that emanates throughout world history can take various forms, of which murder and the persecution of innocents are but examples. He went on to explain to the Jedwabnians that they had now become victims of hate and advised them that if they refused to give in, they would create a "better society".

Encouraged by the entreaties of local right-wing politicians, ${ }^{354}$ the Jedwabnians set about creating this "better society" by constructing monuments commemorating local victims "of the history of love and hate, heroism and bestiality" who had not yet been memorialized. The newly constructed monuments were meant to commemorate events that local residents believed could make a crucial contribution, from the perspective of the debate of 2001, to the process of building a positive image of their past. As Pierre Nora wrote, the objective of the secular monument is to preserve the memory of the event being commemorated, draw attention to its uniqueness and show why that event is important for a given community ${ }^{355}$. However, emphasizing the uniqueness of an event from a group's past is a somewhat alien notion to a community living within a religion-based conceptual memory framework, because, as Halbwachs writes, the religion in question forces memories of other events to be systematically adapted to conform to its premises. If this is not done, these memories are ignored, for nothing

353 Stefanek, "Miłość buduje historię", p. 439.

354 After Krzysztof Godlewski was dismissed from his duties as Mayor of Jedwabne, he was replaced on 29 November 2001 by Michał Chajewski from the Law and Justice party, who was later reelected several times.

355 Andrzej Szpociński, “Miejsca Pamięci.” Borussia, Vol. 29, 2003, p. 21. 
can eclipse an event forming the basis of a religion ${ }^{356}$. The past can never really become "the past" as such because it owes its existence to its ability to endure in the present, which is why stable memory landscapes tend to be created that are little more than "a space of values", which are then experienced by individuals throughout their lives ${ }^{357}$. This is why traditional parish communities, rather than constructing memorials, only erect roadside shrines and crosses. Even though they are very often erected in memory of specific past events, the shrines themselves are meant to organize and structure the space as well as sacralizing it by linking the ancient to the contemporary within a stable and enduring landscape of values ${ }^{358}$.

A good example of this phenomenon is a birch cross that was erected on the road from Orlikowo to Olszewo to commemorate the 150th anniversary of a division of January insurgents commanded by Colonel Józef Konstanty Ramotowski marching through Orlikowo (Fig. 3.1). The cross was unveiled on 15 April 2013 during ceremonies jointly organized by the commune and parish. Next to the cross, a stone containing information about what the cross commemorates has been set into the ground. However, the grass and nettles surrounding this stone have not been trimmed for so long that it is no longer visible from the road. In fact, it is impossible to get close enough to the stone to discover what the cross means. One of our interviewees mentioned that "flooring was meant to be laid, something a bit like that, but it was left as it was, so to speak; it was never done" (M, ca. 35 years old, Jedwabne, June 2016). As a result, rather than acting as a repository of knowledge about the January Uprising in Jedwabne Commune, the cross became a component of the local religious landscape, with little to tell it apart from other wooden crosses in the locality. Its construction was an important act of remembrance because the erection of a cross tends to unite a local community. However, its current role, much like that of other crosses, is to domesticate and structure space. As YiFu Tuan wrote, "visible signs serve to enhance a people's sense of identity; they encourage awareness of and loyalty to place" and community ${ }^{359}$.

356 Maurice Halbwachs, On Collective Memory. Chicago: Chicago University Press, 1992, pp. 91-92.

357 Compare Mikołaj Madurowicz, Sfera sacrum w przestrzeni miejskiej Warszawy. Warsaw: Wydawnictwo Akademickie DIALOG, 2002, p. 49.

358 Adam Białczak, "Krzyże i kapliczki przydrożne zachodniej Kurpiowszczyzny." Zeszyty Naukowe OTN, Vol. XVI, 2002, pp. 253-280.

359 Yi-Fu Tuan, Space and Place: The Perspective of Experience. Minneapolis: University of Minnesota Press, 2001, p. 159. 


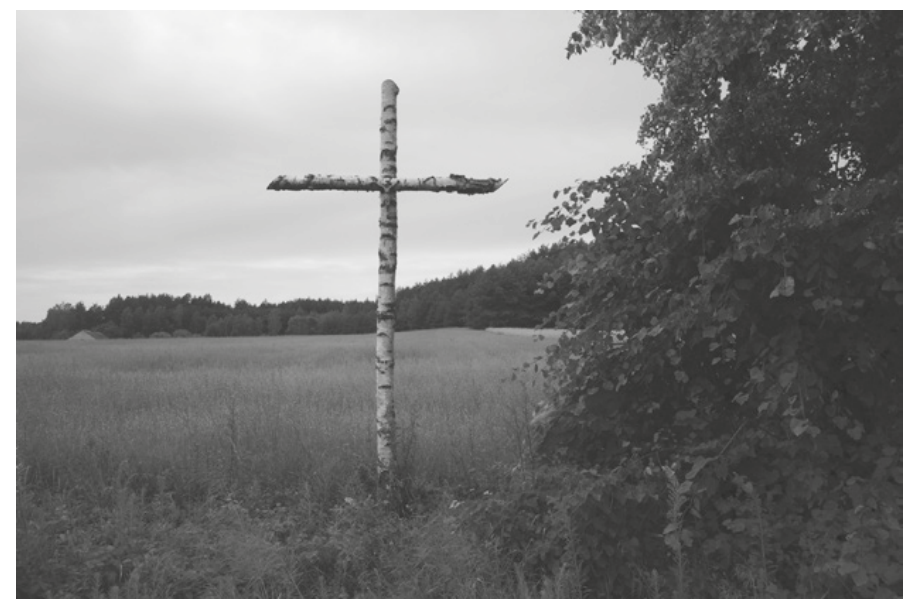

Fig. 3.1: The birch cross by the road from Orlikowo to Olszewo erected on the commune authorities' initiative in 2013 on the 150th anniversary of the January insurgents' march through Orlikowo under the command of Colonel Konstanty Ramotowski, known by the pseudonym "Wawer". Photograph by Zuzanna Bogumił.

Much like traditional roadside crosses, the cross in Orlikowo, rather than encouraging passers-by to directly reflect on the past, invites them to pray, which, according to Halbwachs, ${ }^{360}$ is a distinctive way of reflecting on the past. However, this does not, as would be the case with a memorial, equate to remembering the uniqueness of a specific historical event, because the event that is being remembered in this case needs to carry a moral charge that reminds passers-by of the need to give thanks to God. As we show below, the only memorials that began to function socially in Jedwabne were those that alluded to the tradition of erecting roadside crosses, making it possible for them to blend into the cultural landscape. However, each time this process of integration occurred, the original meaning a memorial's sponsor had attempted to give to it changed.

\section{The PRL Monuments in Jedwabne}

During the Polish People's Republic (PRL), Jedwabne's space was given over to symbolic transformations that complied with the requirements of the new 
system $^{361}$. The Main Market Square was renamed after a general from the Polish People's Army, Karol Świerczewski, and, as mentioned above, a memorial stone bearing the inscription "To those who fell in the struggle to preserve the power of the people" was placed in the same square. This was Jedwabne's most important monument and every official ceremony, including Labor Day (1 May) or the Rebirth of Poland National Holiday, ${ }^{362}$ took place in front of $i^{363}$. However, this monument, which marked the most important space for official ceremonies, is little remembered today. One of our interviewees recalled the monument as follows: "My memory of that's a bit foggy, but some rudimentary parade took place on 1 May. Over there, (...) where the Parkowa restaurant is now, to the center here, (...) there was a monument on the corner there dedicated, supposedly, to some secret police agents whod been shot, but, as sometimes happens with us Poles, there was something deeper there, someone else there... Anyway, this monument was named after those fighting to preserve this socialist power and this monument stood there" (M, ca. 50 years old, Jedwabne, June 2016). However, most of the people we spoke to could not recall that monument and the ceremonies that had been held in front of it.

Local residents' failure to fully comprehend this memorial's meaning was exemplified by a story recounted by Kurkowska-Budzan. On 22 July 1989, a scandal erupted in Jedwabne when someone from the Commune Administration Office laid flowers, as was the tradition, under this memorial having failed to take into account that the country's political system had changed in June. The researcher concludes from this that no one had devised any new memory rituals at that time ${ }^{364}$. By the following year, no one came to the memorial anymore and it was removed, ${ }^{365}$ though not without protest. The reluctance among some Jedwabnians to see it go not only laid bare frictions and political divisions that are still evident today, but also revealed local residents' profound misunderstanding of what erecting monuments means.

361 Kurkowska-Budzan, "Jedwabne and Wizna”, p 245.

362 The Rebirth of Poland National Holiday was the PRL's most important state holiday. It was celebrated annually on 22 July to commemorate the anniversary of the issuing of the Manifesto of the Polish Committee of National Liberation in 1944. The holiday was abolished in 1989.

363 Kurkowska-Budzan, "Jedwabne and Wizna”, p. 253.

364 Kurkowska-Budzan, "Jedwabne and Wizna", p. 253.

365 None of the people we interviewed remembered the exact date. 
In the early 1990s, the chairman of a citizens' commission that had just been established in Jedwabne proposed that the communist-era memorial be demolished. One of the people I interviewed related the incident as follows:

he [the man who tabled the proposal to demolish the memorial], being carried for a moment on this wave, not for the first time in his life, which is why, I'm not mincing my words, he proposed that this memorial be demolished. I was against this (...) when a Bastille is captured, the walls need to crumble; for that reason, the memorial was demolished even though this man was the person who initiated its construction. When the Soviet authorities got here in (...) '44, several sites were uncovered; there, some Jews were shot, there, some Home Army soldiers, here, some secret police agents. So the market square belongs to the agents, so let's build them a memorial. And they, like idiots, demolished this memorial, though it should still be standing today; it wasn't disturbing anyone; it would have created history rather than falsifying it, because there's nothing worse than demolishing these monuments. (M, ca. 50 years old, Jedwabne, June 2016)

It would appear to be symptomatic that the man quoted above perceived the memorial as a marker of history - something immutable that is permanently detached from the life of a given community - rather than a tool for shaping memory whose meaning is in constant flux.

No other monument was erected in place of the dismantled stone. However, at the beginning of the 1990s, a small stone was placed next to the cemetery, which bore the inscription: "In remembrance of ca. 180 people including 2 priests murdered in Jedwabne Commune in 1939-1956 by the NKVD Nazis and the UB. The community" (Fig. 3.2). In his book Neighbors, Gross comments that this inscription is an acknowledgment of blame for the murder of the Jews as the stone does not mention them and should have done if that crime had been committed by Nazis (2001: 170). However, there may be another explanation. It is more likely that Jedwabne's Jews were not mentioned on the memorial by the cemetery because they were already being commemorated by then by another memorial - the boulder at the site of the crime. The memory of victims who identified as Catholic was not commemorated at the time by any memory marker, so someone who had probably lost a family member in the atrocities came up with the initiative of constructing such a monument. It is worth stressing that the memorial did not mention those who had been deported to Siberia. At the time, the history of the Siberians, regarded today as so important, was not commemorated at all. Even though there was nothing to stop anyone doing this after 1989.

The memorial's location is telling. Rather than being placed on the main square, where the dismantled communist-era memorial had once stood, it was erected by a road leading to the cemetery. The Catholic cross and crowned eagle that were placed on it unequivocally describe the national and religious identity 


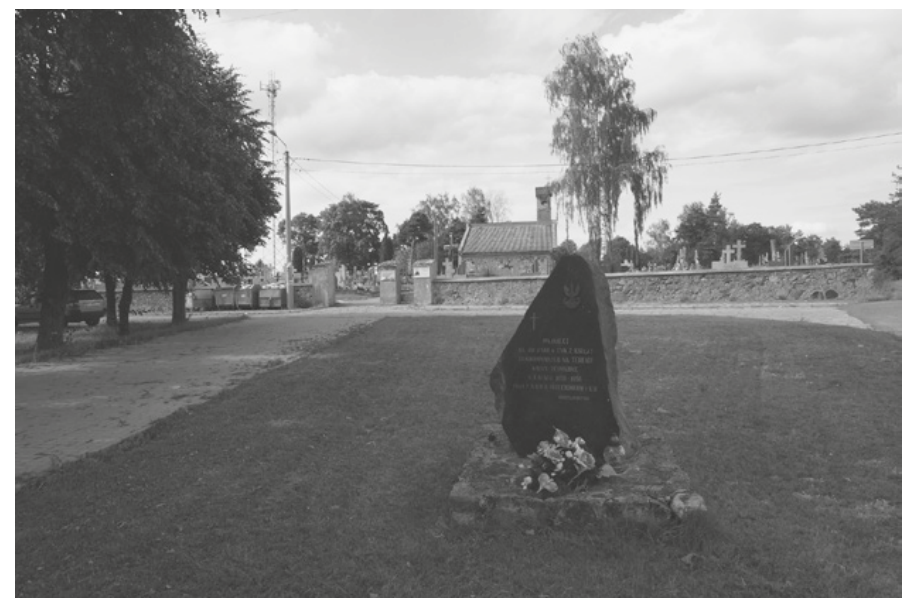

Fig. 3.2: The memorial by the path leading to the municipal cemetery commemorating the 180 people murdered within the Jedwabne Commune between 1939 and 1956 by the NKVD, Nazis and UB. It was erected in the 1990s on the initiative of the commune authorities. Photograph by Zuzanna Bogumił.

of the memorialized group and indicate that the memorial had been invested with a commemorative, rather than an ideological, function. KurkowskaBudzan writes that this memorial was an important focal point during the Jedwabne debate, with people gathering around it, burning candles and praying $^{366}$. However, in 2016, no one was able to tell us anything about it. Even a person working at the town hall who had access to a list of sites of memory not only did not have this memorial in his records, but also knew nothing about it. This is surprising given that there is no way of avoiding this cemetery when walking from the town center to the cemetery, and during ceremonies held on 17 September, there is a procession from the Sybiraks Memorial to the Tomb of the Unknown Soldier that pauses by the memorial by the cemetery to lay flowers and candles there.

The example of these two memorials shows that the Jedwabnians do not consider the role memorials play as receptacles of the past to be particularly important. This makes the question of why they reacted so negatively in 2001 to the construction of a state memorial even more intriguing.

366 Kurkowska-Budzan, "Jedwabne and Wizna”, p. 254. 


\section{The "Jewish" Monument - a Lost Milieu of Memory?}

In 2016, practically all our interviewees had something positive to say about the memorial commemorating murdered Jews constructed in 1961. It turns out from their comments that many Jedwabnians made a point of visiting the memorial, even when official memory rituals changed following the change of political system in 1989. Official delegations from the local high school continued to visit the Jewish memorial and pupils were responsible for tending to the site. What is more, everyone stressed that they took care of the site because they wanted to, rather than being coerced into doing so.

One of our interviewees confirmed how important this site of memory was for the Jedwabnians: "once there was a stone there, in the place where an obelisk is now. (....) Once there was a smaller stone fenced in by some ordinary fence. There, every year, on All Souls' Day, every class had their own duties; we went there, cleaned up, left candles, lay flowers. We didn't know that in that culture, laying flowers isn't allowed, but this was a mark of our respect. Some tragedy certainly happened there because our grandparents told us about it, so we went there out of reverence, guided by our faith" (F, ca. 35 years old, Jedwabne, August 2016). Kurkowska-Budzan, who grew up in Jedwabne, writes that everyone knew about what had happened on 10 July 1941 in Jedwabne (2010). This was confirmed by the interviewee cited above when she told us: "Our grandparents told us about it". This intergenerational transfer explains why young people tended to the memorial and prayed for the dead by it.

Before 2001, memory of the Jews in Jedwabne had a very vernacular char$\operatorname{acter}^{367}$. Community life in such areas is guided by Christian tradition, which is why candles were left by the memorial and the Jews themselves, rather than being commemorated on the day they died, were remembered on the First of November, also knowns as All Souls' Day, a national holiday celebrated throughout Poland. Information about this First of November tradition appeared in all the interviews. This shows that the Jewish memorial was treated like a symbolic cemetery at which the dead, rather than the event itself, were remembered. Even though it took the form of a stone, it began to function much like roadside shrines and crosses dedicated to the tragic fates of a community, which have been described by various ethnographers ${ }^{368}$. However, the national debate introduced

367 Olga Kaczmarek, “Jedwabne - wiedza obrzeży." Kultura Współczesna, Vol. 3, No. 87, 2015, pp. 37-44.

368 Jan Adamowski and Marta Wójcicka, eds. Krzyże i kapliczki przydrożne jako znaki społecznej, kulturowej i religijnej pamięci. Lublin: Wydawnictwo Uniwersytetu Marii Curie-Skłodowskiej, 2011. 


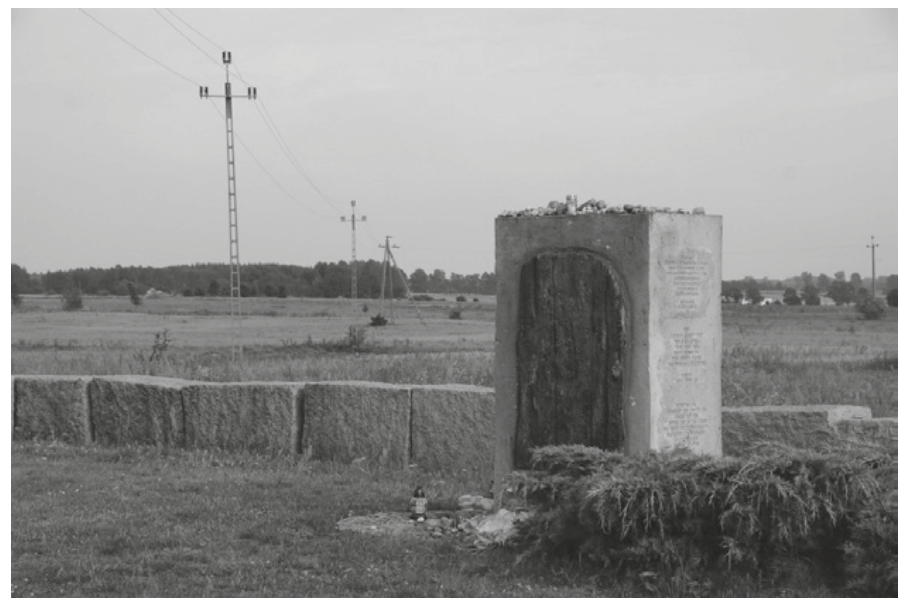

Fig. 3.3: The memorial commemorating the Jews murdered in Jedwabne in 1941, erected on the initiative of the Polish state in 2001. Photograph by Zuzanna Bogumił.

the massacre to the annals of Grand History, destroying its vernacular mode of remembrance in the process.

No one knows what happened to the memorial after it was removed. Space was made for the new, official memorial, which was built by the state in 2001 to coincide with the ceremonies marking the sixtieth anniversary of the massacre (Fig. 3.3). This act of remembrance diametrically changed the memory situation in the town. The new memorial is regarded as an alien object introduced by outsiders from Warsaw ${ }^{369}$. As one woman recalls, "I've been there maybe three times at the most. And that's not because I'm drawn there myself (...) rather to show it to someone. Someone from the family visited, 'go on, show me!'... because to be honest, these people come there, pray there, they have their own place; let them pray, nobody's going to take that away from them, but when it comes down to it, to be honest, there is nothing to draw us there at all" (F, 41 years old, Jedwabne, June 2016).

Many of those we interviewed said that they take visiting guests or family members to the memorial to show it to them. Rather than being a site of memory that the Jedwabnians identify with as "their" memorial, no one wants it but everyone knows where it is. Fifteen years after the debate, emotions had cooled

369 Kurkowska-Budzan, “Jedwabne and Wizna”, p. 246. 
and it was no problem for the local residents to indicate where the memorial is located. Yet the space itself has become alien to them. The construction of the new memorial deprived the Jedwabnians of a symbolic cemetery where they could remember the Jews who had died and replaced it with a place reminding them of their ancestors' sins. This state of affairs was extremely well described by one of our interviewees: "One can visit a neighbor's grave as long as one has a good relationship with it. If one has a lousy relationship with it, as is the case with this memorial I was talking about, the one made of stone and dedicated to the 1,600 victims, made by Poles, where scouts went, burned candles, stood guard, then no one's going to give it a second glance from that time onwards, from 2001, because... this is being interpreted as: you cannot go to the place they attacked you with" (M, ca. 50 years old, Jedwabne, June 2016).

The debate of 2001 appeared to the Jedwabnians to be making all of them, without exception, guilty of the crime of 1941. It created rhetorical figures such as homo jedvabicus to describe a human attitude that "is distinctive for its pettiness, hypocrisy, ostrich-like tendency to bury one's head in the sand, fluttering fear of the unpalatable truth and an inability to cope with the challenge of dispelling the Second World War myth of the suffering and heroic Pole"370. The Jedwabnians reacted to such provocation by entrenching themselves further in this "myth of the suffering and heroic Pole". The milieu was lost.

The feeling that the place has been taken away from the Jedwabnians is further strengthened by the fact that, as many interviewees explained, no one from outside Jedwabne, including Jews, had visited the old memorial for years. The Jedwabnians have always tended to it themselves and it took the events of 2001 to remind others of this place's existence.

Marta Kurkowska-Budzan writes that as recently as 2005, the incumbent head of the local school, Ewa Mańko, was burning candles at the old memorial with her pupils ${ }^{371}$. However, such a custom no longer exists, as we discovered in 2016: "The parents' stance is unequivocal; the school is not to get involved in Jewish ceremonies" (F, ca. 50 years old, Jedwabne, June 2016). This change shows that, at least officially, Jedwabne's stance is equally unequivocal: the massacre of the Jews is not to play any part in the local history.

Another important aspect of the tragedy of the debate of 2001 was that it deprived the Jedwabnians of their favored method of remembering and

370 Jerzy Sławomir Mac, "Homo jedvabicus", Wprost, 22 July 2001, retrieved from https:// www.wprost.pl/tygodnik/10579/Homo-jedvabicus.html (last accessed 5 June 2018).

371 Kurkowska-Budzan, "Jedwabne and Wizna", p. 257. 
commemorating the Jews, a strategy that involved living with feelings of guilt that in a sense invested the town's life with meaning (a need to atone for its guilt). The local residents were also deprived of their site of memory, which was transformed into an incomprehensible alien symbol. This resulted in a feeling of emptiness. During this period, as Kurkowska-Budzyn writes, even the Tomb of the Unknown Soldier in the municipal cemetery no longer served as an official site of remembrance. Certain individuals did in fact continue to lay flowers and candles there, but the official delegations from the school stopped going there in $1989^{372}$. The need therefore arose to devise a new tradition, create a new milieu that would replace the emotional vacuum left behind by the removal of the Jewish site of memory. The initiative was taken by the incumbent mayor, Adam Chojewski, who represented the Law and Justice party. He proposed that a memorial to Siberian deportees who had been native to Jedwabne should be built.

\section{Jedwabne's "Monument Therapy" - the Sybiraks Memorial}

According to one the woman we interviewed, "The Sybiraks Memorial was put up in 2003 and was a response to the year 2001. In 2001, President Kwaśniewski came and apologized for the Jedwabnians, for what they had done, without asking us for our permission, about our rights, about anything at all" (F, ca. 35 years old, Jedwabne, August 2016). Although the decision to construct the memorial was dictated by political concerns rather than the needs of the spirit, it received a positive response from the community. The Jedwabnians joined forces to build both a memorial and a common past (Fig. 3.4).

By this time, the Sybiraks were barely remembered by most Jedwabnians and their memory only really lived on in the minds of those who had experienced the deportations and their families. This memory only really began to function beyond the bounds of the lives of such families in 2001 because, as one of our interviewees explained: "The memory began to be important as soon as they started telling us those lies. The lies of Mr. Gross. That sparked off in people, in Jedwabnians, such, basically, wait, give me a moment, such negative emotions... 'that's not what happened!'. What our grandparents tell us is completely different to his scribblings and tall stories" (M, ca. 35 years old, Jedwabne, June 2016).

It is worth stressing that not everyone was in favor of the memorial being erected. One of our female interviewees recalled: "It probably wasn't a problem

372 Kurkowska-Budzan, "Jedwabne and Wizna", p. 252. 


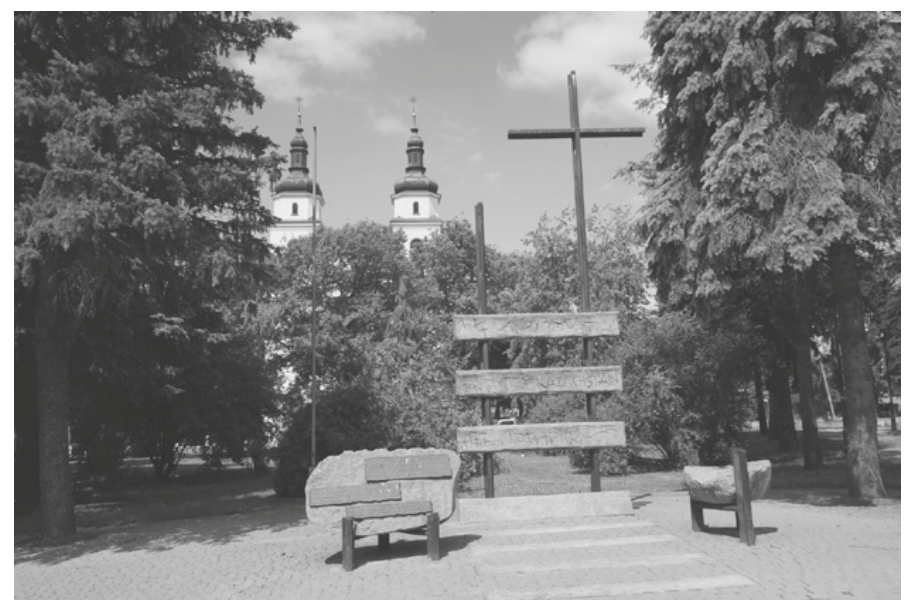

Fig. 3.4: The Sybiraks Memorial erected on the commune authorities' initiative in the town center in 2003. Photograph by Zuzanna Bogumił.

by this stage that this was a memorial for the Sybiraks because I think that was of no concern to anyone, only it was to be erected on the square, maybe it would be better, I don't know, that some flowerbed, say, was there rather than some site of memory, don't you think? But honestly speaking, I've no idea. Personally, I was surprised because I thought it was a good idea, but I don't want to speak for the others [or speculate] why some people didn't want this" (F, 41 years old, Jedwabne, June 2016). The new memorial's construction raised fresh concerns among the community, all the more so in that its unveiling was also very political in nature. The local residents were already tired of making newspaper headlines. The memorial was unveiled "on 3 May because it was as if it'd been ready for spring 2003 and we just didn't want to wait any longer (...) and besides, that 3 May we managed to gather together, which was actually a great surprise for us, but huge crowds of people, half of Poland, came here. [I don't know] why I'm saying that because there were around a dozen color parties. That's why [they came], there was a color party of cavalrymen" (M, ca. 50 years old, Jedwabne, June 2016). This is how the self-appointed defenders of Poland's good name, as Piotr Forecki ${ }^{373}$ defines them, demonstrated their solidarity with the Jedwabnians,

373 Piotr Forecki, Spór o Jedwabne. Analiza debaty publicznej. Poznań: Wydawnictwo Naukowe Instytutu Nauk Politycznych i Dziennikarstwa UAM, 2008. 
who, for the first time since 2001, were able to feel positive emotions toward their past. Twelve years later, the Jedwabne Wiadomości newspaper reported that "the atmosphere was splendid and the patriotic spirit lifted hearts even though the rain was streaming down from the sky" 374 .

Since then, the Sybiraks Memorial has become an integral part of Jedwabne's landscape and delineates the space for every official patriotic ceremony held in the town. These ceremonies take place on 3 May, 17 September, and 11 November, but the second of these, International Sybirak's Day, ${ }^{375}$ is the most important. A local woman gave us her own personal insight into why this might be: "I come from another part of Poland (...) yes, I moved here. It was the German occupation zone there (...) I come here and it's a little like I'm in another reality and that began to fascinate me. And that's why I related to the Sybiraks, because it was something different, something I couldn't read about in textbooks, something that was only in human stories" (F, ca. 50 years old, Jedwabne, June 2016). The same woman went on to explain how the 17 September is celebrated in the town: "this is a school holiday, we go from here with the color parties; off to the church we go for Holy Mass, then we pass by the Sybiraks Memorial and pray there, and then we go of course to the Tomb of the Unknown Soldier". The 3 May and 11 November ceremonies are only held at the church and by the Sybiraks Memorial and are always of a solemn nature. The artistic part of the day, which involves children from schools in Jedwabne, is held at the church, and this is followed by Holy Mass. The woman we spoke to stressed that there is a very clear division between the roles performed by the secular and the religious authorities: "Also, the priest speaks in the church, and here, by the Sybiraks Memorial, it's the mayor who speaks" (F, ca. 50 years old, Jedwabne, June 2016).

Schoolchildren also take part every year in the March of Living Memory, ${ }^{376}$ which takes place in Białystok. The few surviving Sybiraks are invited to a school,

374 Jedwabne Wiadomości, No. 10, Easter 2015.

375 International Sybirak's Day takes place annually on 17 September, the anniversary of the Soviet Union's invasion of Poland in 1939. Sybirak's Day has been organized by the Sybiraks' Association since 1991. The first International Sybirak's Day was held in 2004, and in 2013, the Polish Sejm officially established 17 September as Sybirak's Day. International Sybirak's Day, which takes place in Gdańsk by the Golgotha of the East monument at the Łostowicki Cemetery, and later in Szymbark in Kashubia, attracts several thousand Sybiraks from all of the world every year.

376 The International March of Living Memory of the Polish Sybirak has been organized since 2000 in Białystok and takes place every September. It enables the Sybirak community to preserve the memory of the tragic fates of Polish citizens who were exiled 
where they are treated with great respect by those around them. However, it needs to be considered whether memory of their fate is a living milieu of memory or only a site of memory in which the past resides. One of our interviewees commented that memory of the Sybiraks "will last for as long as some of them are still alive" (M, ca. 35 years old, Jedwabne, June 2016).

It seems that the Sybiraks are aware that their memory is not a permanent feature of the Jedwabnians' memory, a notion that is literally expressed in a commemorative plaque in the local church inscribed with the following words of Cardinal Wyszyński: "When human memory is extinguished - let the stone speak on". This explains why they have taken a number of measures to preserve memory of their suffering within the town's cultural landscape. For example, they collected money amongst themselves for the construction of the memorial in the market square: "[inspired by] that memorial in the park, we did this. There were thirty of us. So twice we contributed 100 zloty each" (F, ca. 75 years old, Jedwabne, June 2016). In 2009, a commemorative plaque appeared in the church. The Sybiraks also awarded "Honorary Sybirak" and silver "Siberian Exiles" badges of merit to various headteachers, the priest, and mayor so that they would continue to nurture the Sybiraks' memory after they had died. As one female Sybirak explained to us, "So now, because I'm the only one left and because I'm unsure when my own time will come, we have arranged to sponsor the school. Two teachers and the headteacher, yes, and the priest and mayor, are involved in this. When I'm no longer here, they're to manage this" (F, ca. 75 years old, Jedwabne, June 2016). The Sybiraks are also lobbying for one of Jedwabne's streets to be named Sybiraków Street, thereby converting soft memory of the deportees into hard memory ${ }^{377}$ by preserving it within Jedwabne's cultural landscape.

An important role in the incorporation of memory of the Sybiraks into the Jedwabnians' memory is played by the memorial's form, which resembles railway tracks inscribed with the names of deportation sites, surmounted by a cross. Apart from the tracks, there is a stone inscribed as follows: "In remembrance of deportees who died of hunger and cold, murdered in the camps of Siberia and Kazakhstan. Sybiraks grateful for the miracle of being rescued and Polish Patriots of Jedwabne. 2002". Below this inscription is another that reads: "In remembrance of the dead, as a warning to the living". The inscription's potential content

to the Soviet Union in the 1940s and 1950s. Marching Sybiraks accompanied by their children and grandchildren are joined by pupils and delegations from schools in Białystok and the Podlaskie Voivodeship. Every year, a delegation is sent to the ceremonies in Białystok from a school in Jedwabne.

377 Etkind, Warped Mourning. 
provoked a great deal of controversy before it was added. There were rumors, confirmed by two of the people we interviewed, that some people wanted the memorial to record "that the deportations were carried out by Jews" ${ }^{378}$. However, in the end, the decision was made, as the city's mayor explained in the Kurier Poranny newspaper, to "copy [the inscription] from another memorial to the Sybiraks in Poland"379.

Given the memorial's form, it perfectly blends in with the tradition of commemorative crosses and shrines while also constituting an intriguing invariant in the form of a sign of the region's religiousness. This aids the assimilation of the memory itself. However, this is not memory of a specific experience, but rather another parable "of the history of love and hate, heroism and bestiality" rooted in the Christian tradition. The history of the Soviet deportations embedded within such an interpretative framework turns memory of the Sybiraks into a new milieu. As one of the women we spoke to explained, "we emulate the Lord Jesus. Like the Lord Jesus bore the cross, every Sybirak bore that cross, that cross. Because that wasn't any kind of life, it was bearing the cross" (F, ca. 75 years old, Jedwabne, June 2016). Once this memory of the deportation experience is inscribed in religious memory, it becomes easier for both Sybiraks and the other members of the parish community to interpret and relate to it, ultimately helping them to integrate with each other. One Jedwabnian stressed: "I think it's good we have such a memorial in the center. Because it somehow helps the community to integrate, at both parish and commune level" (F, ca. 50 years old, Jedwabne, June 2016).

\section{Stage Two of "Monument Therapy" - the Tomb of the Unknown Soldier}

The next memorial to be created, or rather site to be rediscovered, was the Tomb of the Unknown Soldier at the municipal cemetery (Fig. 3.5). This site plays an important role during the annual Day of Remembrance on 17 September. After the Mass at the church and ceremonies by the Sybiraks Memorial, the local residents go to the Tomb of the Unknown Soldier to pray. Even so, it does not appear in the lists of Jedwabne's sites of memory posted on the local commune's website and the townspeople themselves either know little about it or have mixed feelings toward it. One of the people we interviewed told us the story of the origin of this site of memory that, in his view, trivialized the site's meaning:

378 “Tory do nieba”, Kurier Poranny, 26 March 2003.

379 “Tory do nieba”, Kurier Poranny, 26 March 2003. 


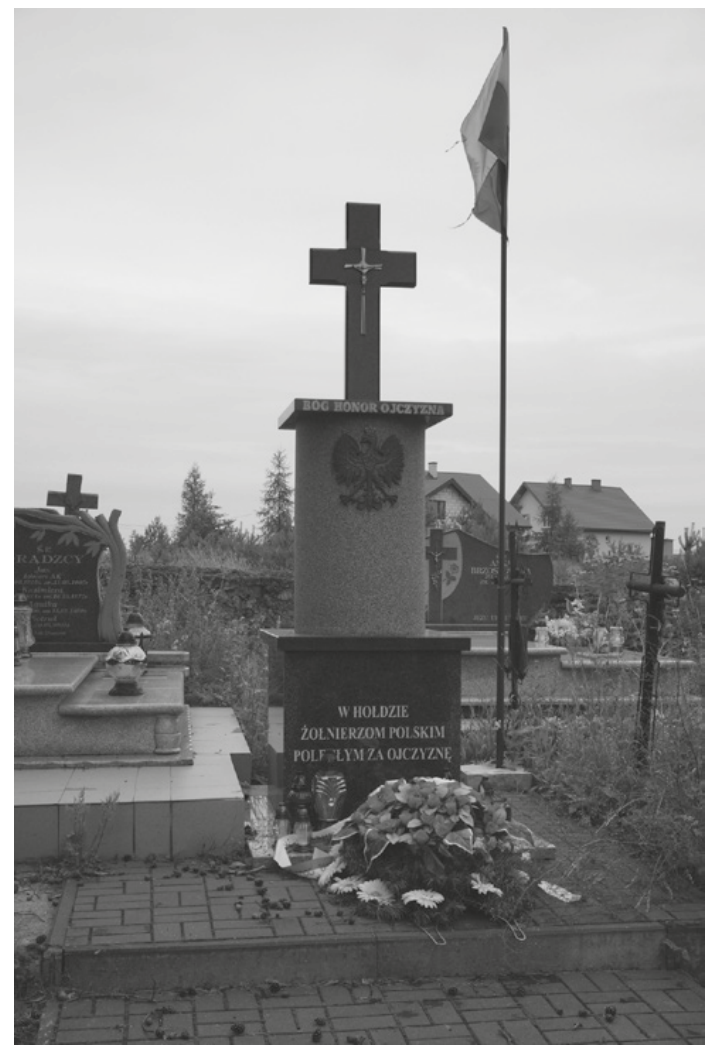

Fig. 3.5: The Tomb of the Unknown Soldier in Jedwabne's municipal cemetery. Its restoration at the beginning of the 21 st century was privately funded by a parishioner. Photograph by Zuzanna Bogumił.

this one monument called a memorial to an unknown soldier [commemorates] a soldier so well known that he was shot by the Germans, by a German patrol during the First World War, a German deserter, some young boy who ditched his unit and took off on his own. As soon as a patrol drove up to him to check his papers and discovered he didn't have a pass, they shot him in the head and moved on. (...) the people went to church on Sunday, and they found the corpse; a boy walked up to it [to take a closer look] - 'Yes, a German in uniform. He shouldn't be left lying in the ditch'; they laid him on a coat and carried him into the church and after the Mass, he was buried in the cemetery. (...) I heard that version from some people from Kubrzany, only there's nobody unknown here, only a deserter who was shot. (M, ca. 50 years old, Jedwabne, June 2016) 
Up until 1989, schoolchildren came to the memorial with an official delegation, but after ' 89 , local residents stopped looking after the monument and the monument fell into disrepair. One of Jedwabne's residents told us that it is was only when she returned to the city after a number of years that she noticed that "it was in such a pitiful state (...) I asked myself: 'where are the community?' The Jews are renovating, doing things. Where are the Poles? Many heroes lost their lives here, something must be [done] (...) and we carried out a reconstruction" (F, 82 years old, Jedwabne, June 2016).

It is worth stressing that the woman who funded the memorial's reconstruction did not know the story of how the memorial came into being. Her decision to sponsor the reconstruction project was guided by what her family had experienced rather than political motives:

My father died in '39. I was still a tiny child. The Germans invaded and took my father into captivity and my father was in captivity. He was 31, a person with higher education. And there were many young boys who didn't know Poland. They didn't want to leave, and my father said 'Don't worry, boys. I'll get you out of there' and they escaped. (...) He took them to Otwock and then said, 'I've no more strength, I'm ready to drop. He went to a priest, he was at confession and there he died (...) and that aroused such patriotism in me, [the fact] that my father had sacrificed his own life in the end. Why shouldn't I continue this? (F, 82 years old, Jedwabne, June 2016)

This history, in which patriotism becomes a value that is more strongly associated with family than nation, formed the basis for the decision to reconstruct the monument. Every year, on 17 September, the woman lays a wreath by the memorial bearing the inscription: "To heroes killed in action for the Motherland". It is worth stressing that she does not treat the memorial as her father's symbolic grave, but rather as "a grave for heroes of the Motherland". For this woman, words like "Motherland", "patriotism" and "hero" are redolent of a higher value with a religious tinge. In fact, she believes that the monument constitutes the materialization of all of these ideas. However, our conversations with other residents indicated that this is not a widely shared notion. One woman commented as follows: "I don't know who built it and on what initiative and who went there" (F, ca. 35 years old, Jedwabne, August 2016). Her words seem to be all the more symptomatic in that the monument is visited every year by a procession of the town's inhabitants marking the 17 September holiday.

There are other sites of memory in Jedwabne where various memory rituals of a patriotic religious nature are performed. For example, the Jedwabne chapter of the Polish scouts commemorates the outbreak of the Warsaw Uprising by gathering together by the Sybiraks Memorial for a moment of reflection and remembrance. One of our interviewees told us: "We don't have any other site 
with a connection [to the Warsaw Uprising], so it has to be here" (F, 41 years old, Jedwabne, June 2016). She went on to explain that this scouting tradition was imposed from above: "This has only been going on, from what I know, for maybe two or three years. The troop [impose] this from above, don't they? The troop from Łomża do this and told us that and [also] that the local teams were to do the same, so it was basically more of a top-down thing than something we wanted ourselves. Anyway, I think it's a good idea. Such moments, I often say, only last a moment, but at least there's this memory..." (F, 41 years old, Jedwabne, June 2016).

The scouts also help to hang red and white ribbon bows on the graves of AK insurgents. One of their teachers came up with this initiative. For several years, on the mayor's initiative, patriotic gatherings around bonfires have been organized for the 3 May and 11 November. As the man explained: "This is a nationwide campaign organized by a Catholic school. The people who came up with the idea posted a template for making posters on the Internet and descriptions of how to organize (a local event). That's why we decided that we should get involved - because it's very important" (M, ca. 50 years old, Jedwabne, June 2016). After the ceremonies at the Sybiraks Memorial, the townspeople gather together at the Jedwabne Commune Cultural Center to sing together and eat pea soup.

It is worth considering whether these activities reflect a genuine interest in national history or whether religious-national interpretations of the past form the basis of the Jedwabnians' local identity. Significantly, one of the women we asked about this responded as follows:

I don't think so, absolutely not. It's on the Third or the Eleventh of November that this can be seen most clearly, when it really seems that if it wasn't for the school - because the teachers demand it and the schoolchildren have to be there - even so, very few of the typical locals attend. And this is happening even more... I don't know, I sometimes think that's strange because everyone essentially regards themselves as Polish - on the Third and the Eleventh, at least, mothers and fathers should take their children and basically go there with them. But, honestly speaking, that's not what happens. (F, 41 years old, Jedwabne, June 2016)

What really brings the Jedwabnians together is not the patriotic holidays, but rather religious holidays and the religious life. A young woman native to Jedwabne was keen to stress: "Generally, there are various kinds of extra holidays (...) And now a kind of reconstruction is also beginning, maybe not reconstruction, but we have a Stations of the Cross [parade] through the town at Easter. Recently, there was a procession of the Three Kings, where everyone taking part, young and old, people of all shapes and sizes, were wearing crowns. The priests 
poured us tea and we marched, sang, prayed" (F, ca. 35 years old, Jedwabne, August 2016). One woman responded very directly when asked what brings the locals together: "church [holidays], church holidays along with the national ones, but the church ones more so, because that's when the procession takes place and people go along, leave their homes. Much depends of course on the parish priest at a particular parish" (F, 82 years old, Jedwabne, June 2016).

\section{The Jedwabnians' Post-Vernacular Memory}

The Jedwabnians have a distrustful attitude toward history, as one of our interviewees expressed extremely well: "for me, history, so to speak, is a bit of a taboo. Because even though there are people who tell as what they experienced, and so on, if someone hasn't experienced something themselves for real, they are so distrustful and don't believe, do they?” (F, 41 years old, Jedwabne, June 2016). Up until 2001, the Jedwabnians lived outside the annals of Grand History. They were a typical parish community that employed traditional strategies to cope with a collectively experienced sense of guilt. The acceleration of history that occurred in 2001 meant that Jedwabnians could no longer be indifferent toward Grand History because it had abruptly and unexpectedly thrust their small town into the very center of its national narrative. The traditional bottom-up strategies for coping with guilt that had been employed up to that point stopped being effective because the Jedwabnians found themselves in a new epistemological situation. External experts came to help them develop defense mechanisms typical of Grand History actors, such as rationalization, the employment of euphemism, guilt denial and victim blaming.

Despite the erection of new monuments that the municipal authorities hoped would historicize the town's past and act as a counterpoint to the historical memorial to the murdered Jews imposed from above, the meaning of these monuments imposed from above changed over time. Some of them were forgotten while others were adapted to the traditional religious landscape of the area, contributing to the milieu of the Jedwabnians' life. As Halbwachs noted, "[e]ven at the moment that it is evolving, society returns to its past. It enframes the new elements that it pushes to the forefront in a totality of remembrances, traditions, and familiar ideas" ${ }^{380}$.

However, Jedwabne's religiosity itself is undergoing change, as it gains an increasingly firm foothold in twentieth-century history. The church is now bedecked with portraits of the blesseds of the Łomża region. Although they had

380 Halbwachs, On Collective Memory, p. 86. 
not yet been noticed by most of our interviewees when we spoke to them in 2016, they still hang there, looking at the faithful during every Mass and the time will surely come when they will be more perceptible and important. One woman also recalled that the Jedwabnians' knowledge of the old saints did not always stand up to scrutiny: "we used to put on Three Kings Day and St Anthony's Day there, yes, they were held there, but everyone understood the point of what was going on, was familiar with the patron saints, well, maybe not entirely" (F, ca. 35 years old, Jedwabne, August 2016). Yet today, the town's religious life is focused around these saints.

A similar fate may greet the blesseds of the Łomża region because their biographies display great potential as instructional materials:

Because, after all, these are not saints taken from somewhere like Italy or Medjugorje. These saints are ours (...) From places around here (...) we have people who lived really close by, you know, for quite a number of years. Also, this is symbolic too and a signpost, in a manner of speaking. Because everyone knows that faith needs to be cultivated. It's not like we have some saints or apostles there showing us in the Holy Scriptures how we should live, but we have humble people who, like this woman, yes, she was blessed yet had no connection whatsoever with the Church, she was an ordinary person who showed what life's all about. (M, ca. 35 years old, Jedwabne, June 2016)

However, these people's life stories are yet to be told in the church because memory actors in the religious sphere take a different approach to those operating in the secular sphere. A cleric explained this approach to us as follows: "because everything in the church is fresh and we are also still creating history. Maybe in the future too" (M, ca. 40 years old, Jedwabne, June 2016). One important feature of religious memory is that it endures even if it is not immediately comprehended and utilized. It actually benefits from the passage of time because this enables new motifs to be adjusted to conform to the canon while motifs that could stand in opposition to it pass into oblivion. This is such a crucial process that it is not only provoking changes in local religiosity but also in Polish Catholicism.

In 2001, Anna Bikont was disturbed by the fact that not one representative of the Polish Catholic Church came to Jedwabne to deliver an official speech. However, the seventy-sixth anniversary remembrance ceremonies were attended for the first time by such a representative, Bishop Rafał Markowski, who apologized for the crime. Bishop Markowski said:

The Church mourns all those who experienced torture, suffering, indignity and humiliation, who unexpectedly met here the kind of death that no one here should have to meet, but at the same time, the Church embraces with great suffering those sons of the Polish nation, especially those who participated in the torment, who directly contributed to this suffering, humiliation and ultimately to their deaths. This is great suffering and 
remorse, suffering for which we apologize to all our brothers and sisters of the Jewish nation. As time reveals, when the human heart is gripped by evil and hatred, when a person is paralyzed from within, this leads to death: this leads to the victims' physical death and the perpetrators' spiritual death ${ }^{381}$.

There is no record of whether the bishop's words directly aimed at the Jedwabnians and expressed in religious language resonated with the local community as much as those about "the history of love and hate, heroism and bestiality" delivered by Bishop Stanisław Stefanek fifteen years before. Many national and nationalist environments defining themselves as Catholic ${ }^{382}$ criticized the bishop for his apology and the position he had adopted, employing arguments that weakened the impact of the evangelical message his speech carried. This highlights the differing positions held by religious memory actors on the question of how Catholics should be integrated into the religious memory of what happened in Jedwabne.

The issue is further muddied by the appearance of other actors exploiting Jedwabne's example in memory projects alluding to different value systems. For example, the Portuguese writer Joao Pinto Coelho alludes in his book Os loucos da rua Mazur, which was awarded a prestigious literary prize in 2017, to Jedwabne's history to demonstrate the scale of Polish anti-Semitism. When the discussion revolving around this book is examined, it soon becomes extremely clear that this book is making a further contribution to the global memory project partially instigated by Gross's Neighbors. However, the Jedwabnians are generally more interested in vernacular activities and vernacular memory projects offering an alternative perspective.

381 https://www.tvn24.pl/wiadomosci-z-kraju,3/pierwsze-przeprosiny-biskupa-wjedwabnem-wyglosil-bp-rafal-markowski,755890.html.

382 One of the most prominent critics was Paweł Lisicki, editor-in-chief of the Do Rzeczy weekly magazine, who said: "These words not only demonstrate the bishop's extreme lack of prudence, but also his stretching of the truth beyond all reasonable bounds. The fundamental question is for whom and on whose behalf Bishop Markowski is apologizing. He says that he is apologizing on behalf of Catholics. The second question is therefore whether Catholics murdered the Jews in Jedwabne. But that is blatantly absurd. This was not done by any Catholics, let alone Polish Catholics. Such a comprehensive apology on everyone's behalf is grist for the religion of the Holocaust's mill and can only accelerate the construction of guilt in Poles". "Za kogo przeprasza w Jedwabnem biskup Markowski?", Do Rzeczy, 11 July 2017. Retrieved from https:// dorzeczy.pl/kraj/35157/Za-kogo-przeprasza-w-Jedwabnem-biskup-Markowski.html (last accessed 2 June 2018). The bishop has also been criticized by other right-wing websites, including Wolna Polska and wPrawo.pl. 
Local memory of this kind is well exemplified by the activities of Kamil Mrozowicz, who was born in 1986 in Kucze Wielkie, a village near Jedwabne. In 2014, Mrozowicz was still explaining his presence at the 10 July ceremonies with comments such as "Memory is the key factor. This is my history and my town"383. Kamil Mrozowicz is an intriguing example of the postmemory generation described by Marianne Hirsch ${ }^{384}$. Even though he heard nothing about the Jews during his childhood, which was spent four kilometers from Jedwabne, he inherited the trauma of their loss. When the debate around the Neighbors book flared up, he was a junior high school student in Jedwabne. As Marcin Kołodziejczyk from the Polityka weekly magazine, who did an interview with Mrozowicz, writes: "For young people from the surrounding area, this was an archeological find - some Jews once lived here? Nearly all the houses in the market square belonged to Jews? They were killed by their Polish neighbors?" 385 . Kamil Mrozowicz stresses in press interviews that this was the time when his interest in his small motherland's Jewish past began. However, when he asked neighbors about the Jews, no one remembered anything or wanted to tell him anything. By contrast with the situation that Marta Kurkowska-Budzan, like him, a Jedwabne native, encountered at the end of the 1990s, when local residents were eager to talk to her about the Jews, no one wanted to speak about them anymore. This, for him, was doubly concerning.

As time passed, he realized that the Jews were continuously present in the town due to little sayings incomprehensible to children but used by adults in their everyday lives, for example, "when someone had something to sell they would say they needed to 'drive it to the Jew'. And when adults played with their children by tickling their knees, they would say: 'just checking if you have a Jew in your knees" "386. In 2017, Mrozowicz received a personal development grant from the Forum of Dialogue, a non-governmental organization engaged

383 Retrieved from:http://www.wspolczesna.pl/wiadomosci/lomza/gal/4898027,jedwabnew-uroczystosciach-rocznicy-mordu-zydow-uczestniczyl-jeden-mieszkaniec, 7684491,id,t,zid.html (last accessed 2 June 2018).

384 Marianne Hirsch, The Generation of Postmemory. Writing and Visual Culture After the Holocaust. New York: Columbia University Press, 2012.

385 “Strażnik pamięci z Jedwabnego. Jak powiedzieć przepraszam”, Polityka, 27 March 2018. Retrieved from: https://www.polityka.pl/tygodnikpolityka/twojemiasto/ 1742744,2,straznik-pamieci-z-jedwabnego.read (last accessed 5 June 2018).

386 Marcin Kołodziejczyk, “Strażnik pamięci z Jedwabnego. Jak powiedzieć przepraszam”, Polityka, 27 March 2018. Retrieved from https://www.polityka.pl/tygodnikpolityka/ 
in Polish-Jewish dialogue. The written justification for awarding Mrozowicz the grant stated: "In his youth, he read Jan Tomasz Gross's Neighbors and confronted the difficult history of his small motherland. He considered it his duty at the time to attend to memory, not only that of the pogrom tragedy in Jedwabne, but also that of the life of the local Jewish community before the war" 387 .

Mrozowicz set to work in a manner befitting of a representative of the postmemory generation. He wanted to tell the story of this past by creating a community library containing publications about Jews, Jewish culture and the Holocaust in Kucze Wielkie, where he grew up. The Białystok newspaper Gazeta Wyborcza was still enthusiastically informing its readers about the project in February 2018. However, by March, Polityka was writing that "few people in Jedwabne shake his hand, many have unfriended him on Facebook. Today, in Kucze and Jedwabne, there are those who walk away when Mrozowicz approaches and those who warn on the Internet that they'll make him dance by poking him with a fork." Marcin Kołodziejczyk concludes his article by writing that the community library will never be created in Kucze. Once again, the local community has defended itself from a new postmemory mode of commemoration.

Mrozowicz is planning to move to America, confirming the accuracy of Joanna Tokarska-Bakir's thesis about an existing tendency in Jedwabne toward self-purification ${ }^{388}$. However, the awful crime the local community committed cannot be escaped, so this self-purification only relates to a particular manner of speaking about the past, rather than the past itself. That needs to worked through in its own way.

It appears that the municipal authorities have found a new way of doing this. They are supporting Ewa Kurek, a historian from Lublin, in her efforts to carry out a new exhumation in Jedwabne that would explain how many people were killed and by what means. According to Kurek, an exhumation "will put an end once and for all to the unfounded conjectures of Polish and Jewish journalists, politicians and officials about Jedwabne, conjectures which both the inhabitants of this town in the Białystok region and most Poles and Polish Jews have had

twojemiasto/1742744,2,straznik-pamieci-z-jedwabnego.read (last accessed 5 June 2018).

387 Maciej Chołodowski, “Jedwabne. Pomóżmy zebrać książki o Zagładzie i kulturze żydowskiej”, Gazeta Wyborcza. Białystok, 5 February 2018. Retrieved from http:// bialystok.wyborcza.pl/bialystok/7,35241,22984095,jedwabne-pomozmy-zebracksiazki-o-zagladzie-i-kulturze-zydowskiej.html (last accessed 5 June 2018).

388 Tokarska-Bakir, Rzeczy mgliste. 
enough of" 389 . When we spoke with the people of Jedwabne in 2016, they did in fact stress that they wanted such an exhumation to be carried out. One woman we interviewed told us: "In 2001, when we had the exhumation, it turned out that the remains of several hundred people were found, but not one and a half thousand. This was not the scale of the tragedy... this was a tragedy and no one will ever deny that, but not to the extent to which they're trying to convince us it was. I hope that there'll be an exhumation now and the proof will be proclaimed, as it exists in reality, and not as they would wish to show it" (F, ca. 35 years old, Jedwabne, August 2016).

In 2001, the decision to exhume the bodies was suspended following an application by the Rabbi of Warsaw and Łódź, Michael Schudrich, who stated that "Respect for the victims' bones is more important to us than knowing who died and how, who killed and how" ${ }^{390}$. Ewa Kurek, initiator of the idea to carry out a new exhumation, is hopeful that her campaign will be successful this time. She has created a special website and has been collecting signatures for a pro-exhumation petition, with the support of the Mayor of Jedwabne ${ }^{391}$. The Białystok issue of the national Gazeta Wyborcza newspaper reported in July 2016 that signatures for the petition were being collected by the church and nearly all Jedwabne's Catholic residents had signed it ${ }^{392}$. As of May 2018, 51, 547 signatures had been collected according to Ewa Kurek's website ${ }^{393}$.

389 Tomasz Maciuszczak, "Historyk z Lublina chce ekshumacji Żydów w Jedwabnem. Zbiera podpisy pod projektem ustawy", Dziennik Wschodni, 19 July 0116. Retrieved from http://www.dziennikwschodni.pl/lublin/doktor-z-kul-chce-ekshumacji-zydoww-jedwabnem-zbiera-podpisy-pod-projektem-ustawy,n,1000183883.html (last accessed 3 June 2018).

390 Quoted from the following article: “'Tak naprawdę ta sprawa nie została wyjaśniona’. Wiceprezes IPN chce ekshumacji w Jedwabnem”. Retrieved from: https://www.fakt.pl/ wydarzenia/polityka/ipn-przeslucha-staruszke-z-jedwabnego-ma-nowe-informacjeo-pogromie/fpyj3gt (last accessed 3 June 2018).

391 The Żadamy Ekshumacji w Jedwabnem! (We Demand an Exhumation in Jedwabne!) website created by Ewa Kurek: https://www.jedwabne-ekshumacja.org/ (last accessed 3 June 2018).

392 Agnieszka Domanowska, “Ekshumacja w Jedwabnem?", Gazeta Wyborcza, 15 July 2016. Retrieved from: http://wyborcza.pl/7,75398,20401801,ekshumacja-wjedwabnem.html (last accessed 5 June 2018).

393 The Żadamy Ekshumacji w Jedwabnem! (We Demand an Exhumation in Jedwabne!) website created by Ewa Kurek: https://www.jedwabne-ekshumacja.org/ (last accessed 3 June 2018). 
In April 2018, the vice-chairman of the IPN, Krzysztof Szwagrzyk, stated: "My position is as follows: the investigation should be carried out and the work in Jedwabne resumed"394. By contrast, Jonny Daniels, chairman of the From the Depths Foundation, which is engaged in building relationships between Poles and Jews, has said: "Even if 40 million people agree with this initiative, there'll be no exhumation in Jedwabne. That is contrary to Jewish law. Jewish souls have suffered enough already and there is no need for them to suffer again"395.

Daniels' statement would appear to be the key to understanding the essence of the conflict that has been raging in Jedwabne since 1941. Rather than being a conflict between political opponents from the right and left, or Jews and Poles, this is a conflict between the living and the dead. Over the sixty years since the crime was committed, the local residents created rituals that have helped them to live among human remains and the souls of the victims. For many years, they visited their memorial on All Souls' Day, in an attempt to wash away their guilt and neutralize the adverse effect of the murder site. When their vernacular memory marker was taken away from them in 2001, their first response was to create new sites of memory that were meant to replace the lost milieu. When the monument therapy they administered to themselves failed to help them, they decided to rid themselves of the deceased by supporting an idea proposed by Kurek, who was calling for the remains to be exhumed and given a dignified burial ${ }^{396}$. However, the Jews did not want to leave Jedwabne, preferring to remain buried where they had burned to death. They have their vocal advocates, like the chairman

394 "Wiceprezes IPN chce nowego śledztwa w sprawie Jedwabnego. 'Sprawa nie została wyjaśniona”, an article published on 24 April 2018 on the gazeta.pl news website, retrieved from http://wiadomosci.gazeta.pl/wiadomosci/7,114883,23312034,wicep rezes-ipn-ekshumacje-w-jedwabnem-powinny-byc-wznowione.html (last accessed 3 June 2018).

395 Tomasz Maciuszczak, "Historyk z Lublina chce ekshumacji Żydów w Jedwabnem. Zbiera podpisy pod projektem ustawy", an article published in Dziennik Wschodni on 19 July 2016. Retrieved from http://www.dziennikwschodni.pl/lublin/doktorz-kul-chce-ekshumacji-zydow-w-jedwabnem-zbiera-podpisy-pod-projektemustawy,n,1000183883.html (last accessed 3 June 2018).

396 Tomasz Maciuszczak, "Historyk z Lublina chce ekshumacji Żydów w Jedwabnem. Zbiera podpisy pod projektem ustawy", an article published in Dziennik Wschodni on 19 July 2016., retrieved from http://www.dziennikwschodni.pl/lublin/doktorz-kul-chce-ekshumacji-zydow-w-jedwabnem-zbiera-podpisy-pod-projektemustawy,n,1000183883.html (last accessed 3 June 2018). 
of the From the Depths Foundation, who has stated: "Another exhumation in Jedwabne would ruin all relations between Poland and the international Jewish community" ${ }^{397}$. However, it would appear that for now the Jedwabnians will have to find a new method for living with the dead.

397 Tomasz Maciuszczak, "Historyk z Lublina chce ekshumacji Żydów w Jedwabnem. Zbiera podpisy pod projektem ustawy", an article published in Dziennik Wschodni on 19 July 2016. Retrieved from: http://www.dziennikwschodni.pl/lublin/doktorz-kul-chce-ekshumacji-zydow-w-jedwabnem-zbiera-podpisy-pod-projektemustawy,n,1000183883.html (last accessed 3 June 2018). 



\section{Markowa $^{398}$}

On 6 March 2018, the Polish parliament established a national holiday on 24 March officially titled the "National Day of Remembrance of the Poles Who Rescued Jews under German Occupation". The new holiday is meant to commemorate "Polish citizens - heroes who, in acts of heroic courage... rescued their Jewish neighbors from the Holocaust planned and implemented by the German occupiers"399. The choice of date was by no means fortuitous. It was meant to evoke 24 March 1944, the day when a Polish family, the Ulmas from the village of Markowa in the Podkarpackie (Subcarpathian) Voivodeship, were murdered for hiding eight Jews. By choosing to declare a holiday on this particular date, the state authorities effectively singled out the Ulmas as people who had made the ultimate sacrifice for helping Jews. By the same token, they indicated that it was this family that were a national symbol of "German crimes perpetrated in retaliation for rescuing Jews" 400 .

The previous year, the status of hero-symbols was being attributed to a completely different group of people. Although the Ulma family were being counted among the ranks of heroes, when it came to Poles who had rescued their Jewish compatriots, representatives of the uppermost echelons of government were most eager to point out the contribution made by Żegota, ${ }^{401}$ a humanitarian organization forming part of the Polish Underground State that organized

398 At this point, I would like to reiterate my gratitude for Marta Karkowka’s contribution to the creation of this chapter. Her manuscript for an article on Markowa provided us with inspiration and the information it contained about the history of Markowa and the Ulma family served as a reference point for these two subchapters. Marta Karkowska also took part in the selection of the interview citations.

399 Cited from the text of the Act of 6 March 2018 on the Establishment of Day of National Remembrance of Poles Who Rescued Jews under German Occupation. Retrieved from http://orka.sejm.gov.pl/opinie8.nsf/nazwa/1947_u/\$file/1947_u.pdf (last accessed 9 July 2018).

400 “Narodowy Dzień Pamięci Polaków ratujących Żydów pod okupacją niemiecką", The Institute of National Remembrance. Retrieved from https://ipn.gov.pl/pl/ aktualnosci/48598,Narodowy-Dzien-Pamieci-Polakow-ratujacych-Zydow-podokupacja-niemiecka-24-marca-.html (last accessed 9 July 2018).

401 Zegota was the codename for the Council to Aid Jews with the Government Delegation for Poland, which was active from 1942 to 1945 as an organ of the Polish government-in-exile. 
assistance for Jews both within and outside the ghettos. The members of Żegota were supposed to symbolize Poles who rescued Jews during the Second World War, and it was originally assumed that it was their contribution which was to be marked by a national holiday, on 17 March. In the end, however, the Polish parliament decided to make a slight change to the new holiday's name and postpone its date by several days. Although the Ulmas are not directly mentioned in the text of the act the parliament adopted, documents that had been adopted earlier and the fact that the new holiday is celebrated on anniversaries of the Ulmas' death show that it is they who have become a symbol of the assistance non-Jewish Poles gave to Jews during the war.

These modifications to the planned legislation also had another dimension. Only a dozen or so years earlier, the Ulma family were only remembered by living family members and the local community ${ }^{402}$. Their story was regarded as just one of many examples of the assistance that ethnic Poles provided to Jews during the German occupation and the risk they took when choosing to do $\mathrm{so}^{403}$. In 1995, they were honored with the title of Righteous Among the Nations, but only became more widely known by virtue of the actions of the Polish Catholic Church, which, in its quest for new blesseds, brought the Ulma family wider recognition by proclaiming them venerable servants of God (that is, deceased persons with respect to whom the beatification process has begun).

The granting of this distinction inspired the local community to take further measures to commemorate the family. Local activists from Markowa and the local commune authorities, who acted on behalf of the local community, funded a monument commemorating the family's death. Following this, the local school was renamed the Ulma Family Servants of God School (in 2006) and later on, the idea to build an Ulma Family Museum of Poles Saving Jews in World War II in Markowa was supported and actively pursued. The new museum was formally opened on 17 March 2016, and the opening ceremony proved to be more than just a local event. In fact, its opening attracted peak-time national media coverage. The opening day itself was not only notable for its spectacular and moving setting but also the exceptional caliber of the participants it attracted: the most

402 Krzysztof Malicki, Poza wspólnota pamięci Życie i Zagłada Żydów w pamięci mieszkańców regionu podkarpackiego. Warsaw: IFiS PAN, 2017.

403 Elżbieta Rączy, "Stosunki polsko-żydowskie w latach drugiej wojny światowej na Rzeszowszczyźnie.” In: Polacy i Żydzi pod okupacja niemiecka 1939-1945, ed. Andrzej Żbikowski. Warsaw: Instytut Pamięci Narodowej, 2006. 
important people in the country took part with the President, Andrzej Duda, at their head.

We arrived in Markowa in July 2016, barely a couple of months after the museum had opened. The museum itself, which is located about 10 kilometers from the famous center of culture at Łańcut, ${ }^{404}$ was already attracting many visitors and was directed at the time by Mateusz Szpytma, a researcher at the Rzeszów chapter of the Institute of National Remembrance (IPN) who is related to the Ulmas. It was mainly his idea to build the museum, and he played a key role as a researcher in the construction of a narrative for the story of the Ulma family.

The opening of the museum provoked another heated debate on wartime relations between ethnic Poles and Poles of Jewish descent. This primarily focused on non-Jewish Poles' attitudes toward their Jewish compatriots and the capacity, scale, and scope of the assistance these Jews were offered by the Polish community ${ }^{405}$. Over time, the museum became an important space for Polish domestic and foreign policy. In October 2016, the presidents of the member states of the Visegrád Group visited the Ulma Museum to lay flowers "by the monument to Victims of the Holocaust and their anonymous Helpers. They also lit candles by a wall containing a list of surnames of Poles who rescued Jews in the Subcarpathian region" ${ }^{\text {"06 }}$. Furthermore, it was here that the Prime Minister Mateusz Morawiecki chose to present foreign journalists with the content of an amendment, dated 26 January 2018, to an act relating to the IPN ${ }^{407}$. The provisions of this statute

404 Łańcut is a historical medieval town which was granted city rights under Magdeburg Law. It contains one of the most beautiful aristocratic residences in Poland and a historical coach house, which currently houses the Lańcut Castle Museum. The museum is an important center of cultural life in this region of Poland.

405 See Piotr Forecki, “Muzeum Zgody w Markowej." Zagłada Żydów. Studia i Materiały, Vol. 12, 2016, pp. 643-652; compare Jan Grabowski and Dariusz Libionka, "Distorting and Rewriting the History of the Holocaust in Poland: The Case of the Ulma Family Museum of Poles Saving Jews During World War II in Markowa." Yad Vashem Studies, Vol. 45, No. 1, 2017, p. 30.

406 “Prezydenci państw Grupy Wyszehradzkiej odwiedzili Muzeum Ulmów”, official website of the President of the Republic of Poland, 14 October 2016. Retrieved from http://www.prezydent.pl/aktualnosci/wizyty-krajowe/art,123,prezydenci-panstwgrupy-wyszehradzkiej-odwiedzili-muzeum-ulmow.html (last accessed 9 July 2018).

407 We are referring here to the act of 26 January 2018 on an amendment to the Act on the Institute of National Remembrance - the Commission for the Prosecution of Crimes Against the Polish, the Act on War Graves and Cemeteries, the Act on Museums, and the Act on the Liability of Collective Entities for Criminal Offences. The full text of the act can be accessed on the IPN's website at https://ipn.gov.pl/pl/o-ipn/ 
contained controversial wording relating to the introduction of penalties for anyone who contradicted the facts by attributing German crimes dating from the Second World War to Poland.

In March 2018, the story of the Ulmas resurfaced, this time as part of the permanent exhibition of the Museum of the Second World War in Gdańsk. As the museum's director Karol Nawrocki explained, "We recognized that the largest museum investment in Polish history simply had to include the Ulma family, brutally murdered by the Germans for assisting Jews" 408 . He went on to add: "I think the Ulma family and Polish Righteous Among the Nations complement this museum superbly". A month previously, in June 2018, the idea had appeared to create a branch of the Ulma Family Museum of Poles Saving Jews in World War II in New York. As the Deputy Minister of Culture Jarosław Sellin stressed, the American metropolis was regarded as the best location for a museum informing visitors of the Ulma family's history, because many of these visitors would be members of the large Jewish diaspora that had settled in the city ${ }^{409}$. This has led to the Ulmas becoming icons of the Polish official narrative tracing relations between ethnic Poles and Poles of Jewish descent during the Holocaust.

We show in this chapter how several decades after the end of the war, the story of the Ulma family suddenly attained the status of a national symbol despite having been relatively little known until then. We reconstruct the process whereby this family has been commemorated and symbolized locally by the state and by the church. We also show how these three dimensions are interlinked.

ustawa/24216,Ustawa.html. In June 2018, the Law and Justice government responded to international criticism and pressure by backing down and withdrawing a controversial provision contained within the act. This provided for the introduction of penalties for anyone who contradicted the facts by attributing German crimes dating from the Second World War to Poland.

408 On 17 March 2018, information about and photographs of the Ulma family were added to the main exposition at the Museum of the Second World War. "Rodzina Ulmów na wystawie głównej w Muzeum II Wojny Światowej!” Nawrocki: 'Jest doskonałym uzupełnieniem, published on the wPolityce.pl website on 20 March 2018. Retrieved from https://wpolityce.pl/historia/386754-rodzina-ulmow-na-wystawieglownej-w-muzeum-ii-wojny-swiatowej-nawrocki-jest-doskonalym-uzupelnieniem (last accessed 20 June 2018).

409 According to an article titled "Muzeum Polaków Ratujących Żydów będzie miało filię w USA. I to w prestiżowej lokalizacji na Manhattanie", Niezależna, 20 February 2018. Retrieved from http://niezalezna.pl/217516-muzeum-polakow-ratujacych-zydowbedzie-mialo-filie-w-usa-i-to-w-prestizowej-lokalizacji-na-manhattanie (last accessed 20 June 2018). 
Our primary objective is to explain why the village of Markowa has become, on the one hand, an important site for the conduction of state historical policy and, on the other, an important site for work being undertaken by the Catholic Church. However, we will also be considering how these activities are perceived by the local villagers and how they describe and interpret the past.

\section{The History of Markowa}

Markowa has a population of 4500 and is the administrative seat of a commune sharing the same name. It belonged to the Rzeszów Voivodeship until 1999, but is now located within the Podcarpathian Voivodeship, which lies in South-East Poland.

The village has a long history. It was founded in 1385. Originally called Markhof, it was settled by colonists from Upper Saxony, Lusatia, and Lower Silesia who were sent there by King Casimir II the Great after those lands were annexed by the Polish Crown. Over the centuries that followed, they were joined by more German settlers. As the authors of studies on the village have observed, Markowa's inhabitants were a close-knit group reluctant to admit newcomers to their inner circle and adopted the Polish language very late, probably between the sixteenth and seventeenth centuries ${ }^{410}$.

The settlement itself was known over the centuries for its imposing size and prosperity. As local residents point out today, Galicia differed from other regions of Poland incorporated into the Austrian Empire in that its inhabitants were granted land ownership rights and local self-government, so their ability to look after their local community's interests and contribute to its development was well-developed ${ }^{411}$. It was in this area that many community ventures such as rural cooperative health centers were first pioneered, but it was also known for its rich cultural and academic life; for example, the village published a local magazine for women called Kobieta Wiejska and the People's University was founded in the neighboring village of $\mathrm{Gac}^{412}$. At the beginning of the twentieth century, the village also contained a cooperative farming society, a cooperative bank, a fire station, theater group, and - in the interwar years - a dairy cooperative. Those living in the village today still not only point out that their homes

410 Małgorzata Drożdż-Szczybura, Wybrane problemy ochrony krajobrazu kulturowego polskiej wsi. Kraków: Wydawnictwo Politechniki Krakowskiej, 2000, p. 11.

411 Tadeusz Szylar, “Markowa wieś spółdzielcza”. In: Z dziejów wsi Markowa, ed. Janusz Półćwiartek. Rzeszów: Towarzystwo Przyjaciół Markowej, 1993, pp. 211-241.

412 Szylar, "Markowa wieś spółdzielcza." 
were constructed in the distinctive local Przysłup style but that they themselves are unique due to the values they uphold, which include thriftiness, industry, punctuality, responsibility, and a penchant for order. Their sense of being different and memory of their shared German ancestry are also evident in other spheres of social life.

In published materials that discuss the village, ${ }^{413}$ it is made clear that after the First World War, although the local inhabitants were aware of their German roots, they most definitely regarded themselves as Poles ${ }^{414}$. This issue turned out to be of key importance during the Second World War, when representatives from the Institut für Deutsche Ostarbeit (IDO) arrived in the village. The remit of this Institute for German Work in the East, which was founded by Governor General Hans Frank, was to collect material evidence for the German character of the Polish lands. After anthropometric tests had been carried out on the local population ${ }^{415}$ complemented by etymological studies of local surnames and ethnographic studies of the village's distinctive buildings, it was decided that the village of Markowa - like the neighboring villages of Gać and Białoboki - was suitable for re-Germanization ${ }^{416}$. As Mateusz Szpytma stresses, the inhabitants

413 The primary publications devoted to the village's history are: Blajer, Wojciech and Tejchma, Jacek (eds.). Markowa - sześć wieków tradycji: z dziejów kultury $i$ społeczeństwa, Mielec: Zakład Poligraficzny Zbigniew Grajek, 2005; Półćwiartek, Janusz (ed.). Z dziejów wsi Markowa. Rzeszów: Towarzystwo Przyjaciół Markowej, 1993. Otherwise, we mainly refer to the only comprehensive history in English devoted to the village's history: Szpytma, Mateusz, The Risk of Survival. The Rescue of the Jews by the Poles and the Tragic Consequences for the Ulma Family from Markowa, Warsaw: Institute of National Remembrance: 2009.

414 Mateusz Szpytma, The Risk of Survival. The Rescue of the Jews by the Poles and the Tragic Consequences for the Ulma Family from Markowa. Warsaw: Institute of National Remembrance, 2009; Szylar, "Markowa wieś spółdzielcza."

415 Jarosław Szarek and Mateusz Szpytma. Rodzina Ulmów. Przejmująca historia polskiej rodziny, która poświęciła swoje życie ratując Żydów. Kraków: Dom Wydawniczy Rafael, 2016.

416 Stanisław Dobosz, “W walce z okupantem hitlerowskim.” In: Z dziejów wsi Markowa, ed. Janusz Półćwiartek. Rzeszów: Towarzystwo Przyjaciół Markowej, 1993, pp. 92-115; Gisela Hildebrandt, Siedlungsgeographische Untersuchungen im Gebiet der deutschmittelalterrlichen Waldhufend"orfer um Landshut: Markowa, Gać und Bialoboki. Krakau: Institut für Deutsche Ostarbeit, 1942; Szpytma, Mateusz. "Stracili życie uratowali świat. Rozstrzelanie 24 marca 1944 r. Józefa i Wiktorii Ulmów i ich dzieci za ukrywanie Żydów.” In: Z przeszłości Żydów polskich. Polityka - Gospodarka - Kultura Społeczeństwo, eds. Jacek Wijaczka and Grzegorz Miernik. Kraków: Instytut Pamięci Narodowej, 2005, p. 212. 
were reluctant to be tested, and only two people ultimately declared themselves to be members of the German nation by signing the so-called Volksliste ${ }^{417}$. According to authors of works devoted to the village's history, this proves the village's Polishness and its allegiance to the Polish state.

Although the villagers were a close-knit community generally reluctant to welcome newcomers into their ranks, quite a large Jewish community had made Markowa their home. Before the war, between 30 and 40 Jewish families comprising a total of over 120 people lived in the village ${ }^{418}$. According to Szpytma, relations between the Jewish and non-Jewish communities were judged to be "satisfactory" ${ }^{419}$ but not very close. The two communities kept their distance from each other but cooperated when the need arose ${ }^{420}$. While living alongside one another, they also generally accepted that their own communities were distinctive and different, but that did not mean that there were no disputes or more serious conflicts before the outbreak of the Second World War, some of which were rooted in religious differences ${ }^{421}$. One of our interviewees described relations as follows: “... there were two nations - side by side, but not together" (M, ca. 80 years old, Markowa, July 2016).

The early stages of the Second World War and policies pursued by the occupying authorities significantly changed social relations in the village. As Jan Grabowski and Dariusz Libionka point out, "As in other areas of occupied Poland known then as the Generalgouvernement, immediately after the arrival of the Germans in September 1939, the Jewish population was subject to increasingly violent terror" ${ }^{\prime 22}$. Subsequently, the occupying forces carried out a number of campaigns resulting in the death of the village's Jewish residents. The largest massacres took place during the middle of 1942, as Grabowski and Libionka write: "Some Jews were taken to the not-too-distant extermination camp in Bełżec, while many others - the children and elderly — were shot on the spot; others fled, seeking refuge in the forests or with their Christian friends and neighbors" ${ }^{\prime 23}$. It was during these massacres that most of the Jews who had survived until then, about

417 Szpytma, The Risk of Survival, p. 55.

418 Grabowski and Libionka, "Distorting and Rewriting the History", p. 32.

419 Szpytma, The Risk of Survival, p. 52.

420 Malicki, Poza wspólnotą pamięci.

421 Szpytma, The Risk of Survival, p. 53.

422 Grabowski and Libionka, "Distorting and Rewriting the History", p. 32.

423 Grabowski and Libionka, "Distorting and Rewriting the History”, p. 33. 
50 people, were killed ${ }^{424}$. As Grabowski and Libionka describe, during "the final solution" in this region "The Germans were involved in concentrating the Jews in nearby Przeworsk and Łańcut, but left the smaller locations to their local enablers. This can explain why the local firefighters, other 'bystanders', and the Polish 'blue' police acquired such a prominent role in tracking down the Jewish refugees. It was impossible for the few gendarmes from Łańcut, Jarosław, or Przeworsk to find and kill the Jews who were hiding in an area in which they were born and raised, in an area which they knew so intimately" 425 . The local Polish community, especially members of the local fire-fighting brigades and blue policemen, were actively engaged in searching for and killing Jews, and this lasted till the end of the war ${ }^{426}$. Despite these very brutal campaigns, a few Polish

424 Rejestr miejsc i faktów zbrodni popetnionych przez okupanta hitlerowskiego na ziemiach polskich w latach 1939-1945. Województwo rzeszowskie. Warsaw: Ministerstwo Sprawiedliwości, Główna Komisja Badania Zbrodni Hitlerowskich w Polsce, 1984, pp. 114-115.

425 Grabowski and Libionka, "Distorting and Rewriting the History", p. 44.

426 Jan Grzybowski and Dariusz Libionka write about the participation of non-Jewish Polish neighbors in the Holocaust on pages 29-60 of an article titled "Distorting and Rewriting the History". Another well-documented example from this region are the events that took place in 1942 in the village of Gniewczyna Łańcucka, where Poles detained and tortured over a dozen Jews at the home of one of the victims in the village center before handing them over to their deaths in the hands of German gendarmes. SeeTadeusz Markiel and Alina Skibińska, 'Jakie to ma znaczenie, czy zrobili to z chciwości?': Zagłada domu Trynczerów. Warsaw: Stowarzyszenie Centrum Badań nad Zagładą Żydów, 2011; Magierowski, "Historyczne, kulturowe i społeczne czynniki", pp. 49-60; Grabowski and Libionka, "Distorting and Rewriting the History", p. 37-40). It is worth adding that over the last few years, several publications have been issued that show the attitude of the non-Jewish Polish population to the Holocaust and the co-participation of ethnic Polish villagers in the extermination of their Jewish neighbors: see Barbara Engelking, Jan Grabowski and Dariusz Libionka, eds., Dalej jest noc. Losy Żydów w wybranych powiatach okupowanej Polski. Warsaw. Vol. 1 and 2. Warsaw: Centrum Badań nad Zagładą Żydów, 2018; Barbara Engelking and Jan Grabowski, eds., Zarys Krajobrazu. Wieś polska wobec Zagłady Żydów 1942-1945. Warsaw: Stowarzyszenie Centrum Badań nad Zagładą Żydów, 2011; Jan Grabowski, Judenjagd. Polowanie na Żydów 1942-1945. Studium dziejów pewnego powiatu. Warsaw: Stowarzyszenie Centrum Badań nad Zagładą Żydów, 2011a; Adam Sitarek, Michał Trębacz and Ewa Wiatr, eds., Zagłada Żydów na polskiej prowincji. Łódź: Wydawnictw Uniwersytetu Łódzkiego, 2012; Joanna TokarskaBakir. Okrzyki pogromowe. Szkice z antropologii historycznej Polski lat 1939-1946. Wołowiec: Wydawnictwo Czarne, 2012. 
neighbors continued to hide Jews in Markowa. According to Szpytma's findings, when the Red Army entered these lands in 1944, it turned out that between 17 and 21 Jews had been saved by the village inhabitants ${ }^{427}$. However, all of them left Markowa after the war for fear of their lives ${ }^{428}$.

\section{The Ulma Family}

It would appear from these publications that Markowa's non-Jewish inhabitants had a friendly and helpful attitude toward their Jewish neighbors. Once the museum opened in Markowa, several publications were issued by Jan Grabowski and Dariusz Libionka that refuted such a vision of friendly cooperation in Markowa by showing that Markowa's non-Jewish inhabitants sometimes participated in the extermination of their Jewish neighbors ${ }^{429}$. These works describe the social conditions within which those who assisted Jews were functioning. However, the museum's founder and first director cast doubt on the veracity of the documents Grabowski and Libionka were citing from ${ }^{430}$. It is important

427 Szpytma, The Risk of Survival, p. 57; compare Grabowski and Libionka. "Bezdroża polityki historycznej", p. 623.

428 Grabowski and Libionka recall the testimony of the Riesenbachs family who survived by hiding in a house belonging to Józef and Julia Bar and wanted to reclaim their house after the war. However, the villagers who had lived in their house from 1942 did not welcome the fact that the Jewish family wanted to "reclaim their property". They were attacked by armed men one night and the next day escaped from Markowa, never to return. See Grabowski and Libionka, "Distorting and Rewriting the History", p. 57.

429 Here, we are primarily referring to pages 29-60 of Jan Grabowski and Dariusz Libionka's article "Distorting and Rewriting the History", p. 29-60; the Polish version of this article was published on pages 619-642 of a volume titled Zagłada Żydów. Studia i Materiaty, Grabowski and Libionka. "Bezdroża polityki historycznej”, pp. 619642. Markowa is also mentioend in the Engelking, Grabowski and Labionka, eds., Dalej jest noc. Losy Żydów. In 2011, Jan Grabowski and Mateusz Szptma polemicized on Markowa's non-Jewish residents' attitude to the Holocaust in the magazine Więź: Jan Grabowski, "Prawda leży w mogiłach", Więź 8-9 (634) 2011, pp. 103-6; Mateusz Szpytma, "Sprawiedliwi i inni”, Więź 10 (636), 2011.

430 Mateusz Szpytma, "Sprawiedliwi i inni”, Więź 10 (636), 2011; "Demaskujemy kłamstwo w 'Gazecie Wyborczej' na temat Polaków rzekomo mordujących Żydów." the wPolityce.pl website. 20 Dec. 2016. Retrieved from: https://wpolityce.pl/ historia/320314-demaskujemy-klamstwo-w-gazecie-wyborczej-na-temat-polakowrzekomo-mordujacych-zydow (last accessed 10 July 2018); Mateusz Szpytma, "Czyje te bezdroża? Polemika z tekstem 'Markowa. Żydowska śmierć, polska wina, wspólny strach'”. Gazeta Wyborcza. 6 Jan. 2017. Retrieved from: http://wyborcza. 
to stress that it is mostly Szpytma's books that have come to form the basis of public knowledge relating to the Ulma family's history and shaped the discourse relating to the events in the village.

Both Szpytma and other local historians stress that Józef Ulma was a wellknown figure in Markowa, respected for his industry and resourcefulness, qualities that were greatly appreciated by the local community ${ }^{431}$. He was regarded as a person involved in the life of the local community, as is clear from his activities as a member of the Wici Union of Rural Youth, which gathered together people interested in agrarianism, and his commitment to cultural education and other educational activities (including his involvement in the people's universities). He was also respected for his interest in technological advances, his innovative approach to fruit farming, and his professional commitment to beekeeping and sericulture ${ }^{432}$. He was also remembered as a person willing to take on new challenges, as evidenced by his plans to move his family to the eastern regions of Poland, where he purchased a farm. However, after military operations began in 1939 and the Red Army moved into the territory that contained his new farm, his family were forced to change their plans and stay in Markowa.

As soon as the war broke out, Józef Ulma went to the front, but had to return after becoming seriously ill. With the family living together under one roof again, Ulma devoted himself to farming and photography. He photographed his family, documented the life of the village, and took photographs for documents. From this work, but also farm work and extra jobs, the whole family managed to support themselves. During the German occupation, probably in late 1942, after the massacres of the village's Jewish inhabitants mentioned above, the Ulmas assisted a Jewish family by constructing a hideout in the forest ${ }^{433}$. Around the same time, the Ulmas provided shelter in their home for eight Jews who they had known before: Saul Goldman and his four sons, whose first names have not survived (known in neighboring Łańcut as the Szalls), and the two daughters and granddaughter of Chaim Goldman of Markowa - Leah (Layta) Didner and her

pl/magazyn/7,124059,21211362,czyje-te-bezdroza-polemika-z-tekstem-markowazydowska.html (last accessed 10 July 2018).

431 Wawrzeszczak, "Józef Ulma (1900-1944)." In: $Z$ dziejów wsi Markowa, ed. Janusz Półćwiartek. Rzeszów: Towarzystwo Przyjaciół Markowej, 1993; Szarek, Jarosław and Mateusz Szpytma. Rodzina Ulmów. Przejmująca historia polskiej rodziny, która poświęciła swoje życie ratując Żydów. Kraków: Dom Wydawniczy Rafael, 2016.

432 Wawrzeszczak, "Józef Ulma (1900-1944)."

433 Szarek and Szpytma. Rodzina Ulmów. 
daughter, whose name has not survived, and Genia (Golda) Grünfeld ${ }^{434}$. Mateusz Szpytma writes that every member of the Ulma household moved about quite freely and the Jews were operating an illegal tannery that helped to support the dozen or so people living in the small house. They were also helping with farm work. For Szpytma this is clear from surviving photographs ${ }^{435}$ as well as anonymous threats directed at Józef Ulma, which have also survived, which indicate the possibility of the whole family being turned in to the authorities ${ }^{436}$.

The Germans were probably informed that the Ulma family were hiding Jews by Włodzimierz Leś, a "blue" police officer from Łańcut ${ }^{437}$ who had hidden the Szalls earlier. On the morning of 24 March 1944, five German military policemen accompanied by several "blue" policemen appeared in front of the Ulma's home. They were commanded by a German - Lieutenant Eilert Dieken. The Łańcut-based unit were well-informed. Its commanders knew that Jews were being hidden in the Ulmas' home, so they headed straight for the Ulmas' home on the edge of the village. As dawn broke, they surrounded the house and forced their way inside.

The military police found all the Jews who were in hiding. They shot them first and then Józef and Wiktoria (who was seven months pregnant) and their six children (eight-year-old Stanisława, six-year-old Barbara, five-year-old Władysław, four-year-old Franciszek, three-year-old Antoni, and eighteenmonth-old Maria). According to the account given by Edward Nawojski, one of the cart drivers present at the executions, the children were shot by Joseph

434 Szpytma, The Risk of Survival.

435 Mateusz Szpytma Sprawiedliwi i ich świat. Markowa w fotografii Józefa Ulmy. Warsaw: Instytut Pamięci Narodowej - Komisja Ścigania Zbrodni Przeciwko Narodowi Polskiemu; Kraków: Instytut Studiów Strategicznych, 2015.

436 Szpytma, The Risk of Survival.

437 Documents produced by the underground resistance reveal that it was Włodzimierz Leś, a Blue Police officer from Łańcut, who was the chief suspect. At the beginning of the occupation, Leś offered assistance to the Szall family in return for a fee, but as soon as their money ran out, he threw them out of the hideout. In all likelihood, it was Leśs fear of losing the property he had seized that inspired him to rid himself of the Szalls when he established that they were being hidden by the Ulmas. On 25 March, he was present with the other Blue Police officers as the German military police officers carried out the executions. A few months later, on 10 September 1944, shortly after the Soviet army arrived, he was served the death penalty by the Polish Underground State. Retrieved from: http://dzieje.pl/aktualnosci/historyk-dowodzacyakcja-zamordowania-ulmow-uniknal-odpowiedzialnosci (last accessed 9 July 2018). 
Kokott ${ }^{438}$. The cart drivers attended the murders, so that they could serve as a warning that would strike fear into the rest of Markowa's inhabitants of the consequences of aiding Jews and also induce them to turn in those people who had found shelter with their neighbors. Jan Grabowski claims that this aim was in fact achieved because some local peasants did indeed murder some Jewish neighbors that had been hiding ${ }^{439}$.

Immediately after the execution, the German military policemen ordered that the family and Jews who had been in hiding be buried on the family's farmland in two separate graves. Any property belonging to the Ulmas and the Jews who had been hiding in their home was plundered by the Germans and transported to Łańcut. The local residents and the village leader, Teofil Kielar, arrived at the scene on the orders of the Germans just after the mass murder had been committed. They were tasked with digging pits and burying the victims in them. Despite the danger, five men from Markowa, either relatives or neighbors of the Ulmas, returned to the site that week under the cover of darkness to dig up the Ulmas' bodies and rebury them at the same place in coffins. In January 1945, after the front had moved westward and the Red Army had seized power of the area, the Ulmas' corpses were dug up again and moved to a Catholic cemetery, where they have lain in rest to this day (Fig. 4.1). In 1947, the corpses of the eight Jews were also exhumed and later buried at the Victims of Nazism Cemetery in Jagiełła-Niechciałki ${ }^{440}$.

\section{The Beginnings of the Ulmas' Commemoration}

There are no sociological studies capable of offering us any insight into the nature of vernacular memory of the Ulmas in Markowa before the commencement of the beatification process and the museum's construction. When we visited Markowa in 2016, the local residents were happy to talk to us about the village's

438 Joseph Kokott was the only one of the military policemen to face trial. In 1957, he was arrested on Czechoslovakian territory, from where he was extradited to Poland. In 1958, a court in Rzeszów sentenced him to death, a ruling that was later commuted to life imprisonment and then a 25 -year prison term. Kokott died in a penitentiary in 1980. Szpytma, The Risk of Survival, p. 16.

439 Jan Grabowski, "Prawda leży w mogiłach”, Więź, Vol. 8-9, No (634, 2011b, pp. 103-6).

440 This cemetery is the place of rest of people murdered during the Second World War. The collective graves contain the bodies of Soviet prisoners-of-war from the German camps in Wołka-Pełkińska and Pełkinie as well as Poles, Jews, and Roma. Some of the corpses that were brought there were exhumed after the war from graves in nearby settlements. 


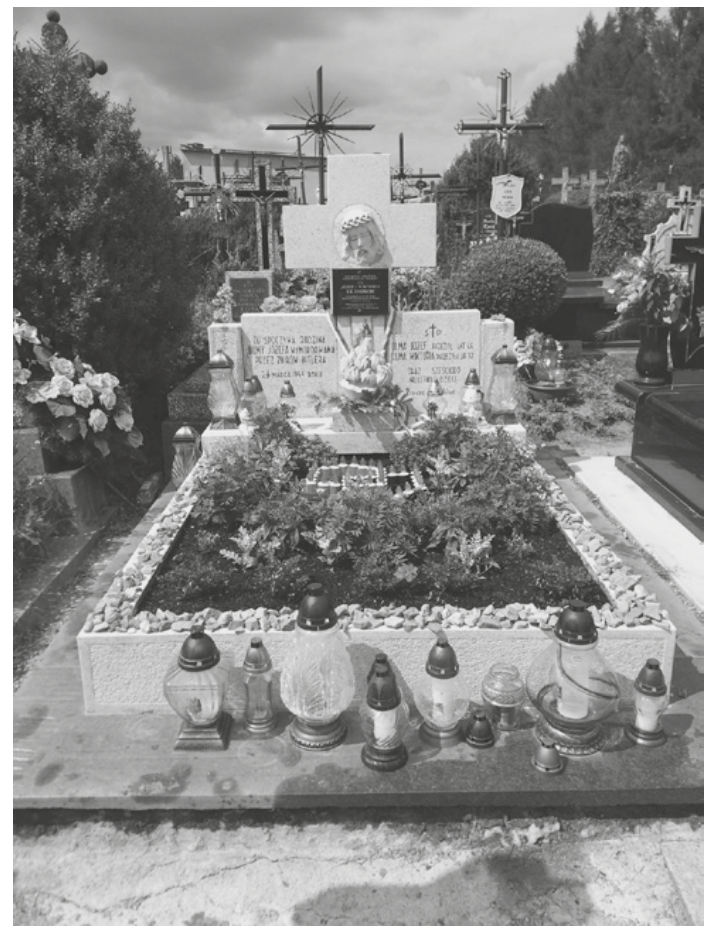

Fig. 4.1: Grave of the Ulma family at the Catholic cemetery in Markowa. Photograph by Marta Karkowska.

past, the Ulma family, and their commemoration. It was extremely evident that the manner in which they were speaking about the war was greatly influenced by Mateusz Szpytma's publications ${ }^{441}$ and the attempts, initiated in 2003, to

441 The first issue of Mateusz Szpytma and Jarosław Szarek's book about Ulma was published in 2004, bearing the title: Ofiara Sprawiedliwych. Rodzina Ulmów - oddali życie za ratowanie Żydów (The Sacrifice of the Righteous. The Ulma Family - They Surrendered Their Lives for Rescuing Jews). Kraków 2004; the second issue of the book, which was supplemented with new material, was published in 2007 with a new title: Sprawiedliwi wśród Narodów Świata. Przejmujaca historia polskiej rodziny, która poświęciła swoje życie, ratując Żydów (Righteous Among the Nations. The Moving Story of the Polish Family Who Sacrificed Their Lives Rescuing Jews). Kraków 2007. The third edition, which was published in 2014, was renamed: Ulmów. Przejmująca historia polskiej rodziny, która poświęciła swoje życie ratując Żydów (The Ulmas. The Moving 
secure the Ulmas' canonization. Everyone spoke proudly of the Ulmas' conduct and emphasized their fellow residents' positive attitude toward Jews. None of their statements mentioned the Jew hunts or local inhabitants' complicity in the Holocaust that we know about from archival documents. Even though this was before the discussion about the museum really flared up and the museum itself became a central element in Polish historical policy ${ }^{442}$, it was extremely evident that the local community had already reached a consensus over a vision of their past and that the conceptual framework of their vernacular memory had arisen from events that had taken place in Markowa after 2003.

Local residents recall that when news of the Ulmas' death reached their families and the other villagers, it came as a shock. Wiktoria's nephew made the following comments during an interview: "That morning, mum went to Holy Communion. The day before had been confession, but after afternoon confession, no one was allowed to go to communion, they had to go the next day, had to go after fasting. She went, found out what had happened on her way and even turned back. Also, before eight, because I still hadn't gone to school, she told us what had happened. (...) Well, it descended on us like a bolt from the blue" ${ }^{\text {"443 }}$. Another Markowa resident recalls the moment as follows: “(...) at that time, confession was on Saturday in Markowa and people came out of the church on Sunday, because that communion was the next day... That's all everyone was talking about, about that tragedy. And I also came out of the church, only then discovering that the whole family had been shot" (F, ca. 85 years old, Markowa, July 2016).

Significantly, all the people we interviewed stressed that this news reached them through unofficial sources, so they refrained from speaking about it in public places. One woman we spoke to pointed out that even during the Holy Mass at the church, the parish priest Ewaryst Dębicki made no mention of the tragedy (F, ca. 85 years old, Markowa, July 2016). Instead, it was discussed in small groups and within the family or with neighbors and acquaintances who were known well enough to be trusted.

Story of the Polish Family Who Sacrificed Their Lives Rescuing Jews). Kraków 2014; The fourth edition, which was published in 2016, bore the same title as the 2014 edition. In this book, we are referencing this 2016 edition.

442 Piotr Forecki, “Muzeum Zgody w Markowej." Zagłada Żydów. Studia i Materiały, Vol. 12, 2016, pp. 643-652.

443 From an interview with Stanisław Niemczak conducted for Radio FARA on 22 March 2018. Retrieved from http://przemyska.pl/2018/03/22/sympozjum-orodzinie-ulmow/ (last accessed 9 July 2018). 
The massacre influenced the attitude of local residents to Jews in hiding. Nevertheless, the people we interviewed, irrespective of whether they came from older or younger generations, stressed on many occasions that despite fearing for the lives of their families, the stress-laden atmosphere and tension, many people decided to continue helping. They were often supported by neighbors who assisted with everyday tasks and in cases when they justifiably feared that the fact they were sheltering Jews was about to be discovered. Many were keen to stress that "the people did not give out" the secrets of the non-Jewish residents of Markowa who had been assisting members of the Jewish population ${ }^{44}$. One of the people we interviewed mentioned that "Some people may have known because a few of these Jews had managed to survive there. They threatened some of them and they had to run away. Basically, they chased them out to avoid putting themselves at risk..." (M, ca. 65 years old, Markowa, July 2016). Information about hosts murdering the Jews they had been hiding can also be found at a permanent exposition at the museum in Markowa ${ }^{445}$.

It turns out from our conversations that what tormented the villagers most after the murders was the fact that the Ulmas were not buried in accordance with the religious rituals to which the community was bound. This explains why, when the war ended and the Red Army entered the region, the villagers secretly moved the bodies of the murdered family, without gaining the consent of the incumbent authorities, from the makeshift pit grave in which they had been buried to a Catholic cemetery. In this way, they honored an important social commitment obliging them to ensure that members of their own community received a dignified burial in consecrated land: "They took them away at night in the winter on sledges across the fields to the cemetery so that no one would see. There was no Mass at that point. Maybe later, I don't remember. Only that's how

444 Since we conducted our research, the dispute over the consequences of the Ulmas' deaths and the local community's reaction to it has become a topic of discussion in the Polish press, mainly in the Gazeta Wyborcza newspaper.

445 Holocaust researchers argue that this issue has not been given enough emphasis by drawing attention to the continual baiting of and pogroms against Jews in occupied Poland. According to them, the fact that the museum does not dedicate special attention to this issue is symptomatic of the falsification of history through the concealment of pertinent historical facts (Grabowski and Libionka. "Bezdroża polityki historycznej"; Grabowski and Libionka, "Distorting and Rewriting the History"; also see the conversation between Adam Leszczyński and Jan Grabowski titled "Na likwidację Żydów pojechałem. Jan Kowalski", which was published in Gazeta Wyborcza on 30 February 2016). 
they took them away and buried them all in a single grave" (F, ca. 85 years old, Markowa, July 2016).

For years, this swiftly dug makeshift grave did not stand out in any way from the other ones in the cemetery. Moreover, immediately after the war, the Ulmas' death was commemorated in a typical fashion rather than being afforded special status. It was not marked out as a supreme example of German repression. Not even by the state authorities or other institutions established to document and commemorate sites, events, or people associated with the Second World War. Locally, the murders were spoken of as an example of an exceptional family tragedy rather than an exemplification of German crimes or a watershed moment in the local community's history. Although the family were remembered, the story of their deaths was not treated as an example of martyrdom or exceptional sacrifice. Instead, the focus was placed on the actual tragedy of a whole family, especially as so many young children had been shot. At the same time, reasons were sought for this murder. It was recalled that Józef Ulma had been repeatedly warned that the village knew he was hiding Jews and such widely accessible knowledge could cause a tragedy. One of our interviewees commented as follows: "But they were warning him, continually telling him, 'Józek, chuck out those Jews, because it'll turn tragic for you some time'... But he said, 'Judge not, that ye be not judged'446. He was saying that all the time: 'Judge not, that ye be not judged'. But he didn't listen. (...) He was so sure his children [were safe]" (F, ca. 85 years old, Markowa, July 2016).

Evidently, however, these post-war discussions and deliberations on why the hiding Jews were not turned in or refused any more help did not extend beyond relatively closed circles of trusted people. Significantly, this convention of only discussing Jewish neighbors or acquaintances in hiding and the people who hosted them in private essentially continued unabated over the decades that followed. Although the local community knew or had worked out which of the

446 Ulma was responding by citing St Matthew’s Gospel (7:1): “Judge not, that ye be not judged". Using biblical quotes to express important ideas grounded in morality was very popular in the Polish countryside. As Magdalena Zowczak shows, Polish rural communities, rather than referring dogmatically to the teachings of the Church, creatively combined these teachings with the symbolism of non-Christian beliefs and religious motifs derived, for example, from the Jewish belief system. This led to the development of a kind of folk bible in which beliefs rooted in Old Polish culture co-occurred with contemporary beliefs. See Magdalena Zowczak, Biblia ludowa. Interpretacje wątków biblijnych w kulturze ludowej. Wrocław: Funna (Monografie Fundacji na rzecz Nauki Polskiej), 2000. 
Poles had been hiding Jews during the war, this was not a topic suitable for public discussion. The convention adopted during the war of keeping silent about the identities of those who had been hiding Jews continued after the war ${ }^{447}$. We recorded the following conversation between villagers during our research:

R1: After the war, they weren't admitting too much. But even then, it was said there'd been Jews among us.

R2: Well, that's because once they'd packed up and gone, no one was afraid anymore.

R: But no one saw it as anything to boast about. (F and M, ca. 75 and 80 years old, Markowa, July 2016).

We not only asked the people we interviewed whether the war period was spoken of in front of children or among acquaintances, but also whether the local community remembered the Ulma family as well as Jewish residents of the village and surrounding area being hidden or turned in. They responded by indicating that their only sources of such knowledge were the accounts they had heard from their close family members - mainly their mothers, fathers, or grandparents - or conversations they had witnessed by chance as children. One statement after another confirmed that this was not a topic brought up in daily conversation, even several decades after the war murders had been committed. The following statement given by one of our interviewees is typical: "You know, I didn't encounter [any information about the Ulmas' death]. Apart from what my mother told me, I didn't encounter anything. Even though something of the kind happened, even though that happened... I used to go to my friend's house, but nothing was ever said about it" (M, ca. 82 years old, Markowa, July 2016).

The lack of wider discussion on the rescued Jews and the Ulma family's deaths, even many years after the event, is reflected in the statements we took from representatives of the younger generation: "around such benches there were sometimes stories of various kinds... they were probably remembered, I'm convinced.

447 According to Joanna Tokarska-Bakir, keeping silent was the strategy favored by those who were hiding Jews while living in their communities. As she explains, "Rescuing Jews may be described in terms of a genuine war pitting Pole against Pole that involved lone rescuers (...) deprived of social support. (...) their communities perceived them as having turned their backs on bonds of loyalty due to their families, villages and even, according to the rightist definition popularized since before the war, their nation and faith" (Tokarska-Bakir, Okrzyki pogromowe, p. 36). What is more, this strategy was also employed after the war by those who had rescued Jews. As Tokarska-Bakir makes clear, many of the Righteous who testified before historical commissions asked for their personal data not to be revealed because they wanted to live in peace in their local communities. Tokarska-Bakir, Okrzyki pogromowe, p. 46. 
My father also generally had little to say about family stories. Mum was a little younger, and so on, so such things were of little interest to them, as it were. Such things were never of much interest to my family, or at least to my closest family" (M, ca. 40 years old, Markowa, July 2016).

Other villagers stressed, when reminiscing about the 1980s and 1990s, that although they themselves knew the Ulmas' story, they did not treat it as exceptional or worthy of special commemoration. This story was also not treated as a foundational event for the local community, as was the case in Michniów, or now is in Markowa. On the contrary, for many years memory of the events of 1944 did not form a basis for integration or the building of collective group identity and were therefore not perceived as being unusual enough to become a focus of ceremonial communication ${ }^{448}$. Essentially, apart from the standard, classic remembrance practices employed at the cemetery to commemorate the dead, the local community did not mark this tragedy out as being exceptional and therefore of importance to them:

Something could be heard about the Ulmas before, but I don't know if it ever occurred to anyone that they could be beatified. Basically, children were shown that the cemetery is here, that they were murdered in such a manner, that the grave is here. ( $M$, ca. 45 years old, Markowa, July 2016)

I knew something, my mum told me a little, that such a murder of the Ulma family had taken place. But such events were so commonplace that little more was said about it. (M, ca. 80 years old, Markowa, July 2016)

Actually, we only started chronicling this when everything began when the priest proposed the monument initiative. It was basically then. (M, ca. 82 years old, Markowa, July 2016)

The fact that the Ulmas' tragic death was not always a significant event in the village's life is extremely well exemplified by the extent to which this event made its presence felt in the work undertaken by the Society of Friends of Markowa, which was founded in 1979. On 25 August 1985, the six-hundredth anniversary of the village receiving its foundation charter, the Society launched the Museum of the Village of Markowa Prize. This was accompanied by a number of projects informing visitors about Markowa's history. Various materials ${ }^{449}$ were published, academic sessions for the general public were organized, and old photographs

448 Jan Assmann, Cultural Memory and Early Civilization: Writing, Remembrance, and Political Imagination. Cambridge: Cambridge University Press, 2011.

449 Janusz Półćwiartek, ed. Z dziejów wsi Markowa. Rzeszów: Towarzystwo Przyjaciół Markowej, 1993; Wojciech Blajer, “Z dziejów wsi Markowa - recenzja”, Rocznik Przemyski, Vol. 32, No. 1 (1996), pp. 141-147. 
and documents were gathered together. The published materials that have survived from this enterprise show that Józef Ulma, when he was mentioned at all by the Society members, was remembered for his involvement with the community and interest in agrarianism or as a photographer. Information about his death and those of his family was very much a side issue in their reflections on the war period ${ }^{450}$.

Furthermore, the site where the Ulmas and the Jews they had been hiding were murdered was not marked in a special way or frequently visited. However, there was an enamel plaque ${ }^{451}$ there, which had been installed by scouts. Some of our interviewees remembered this plaque and one of them commented: "As for [the event] being commemorated, because there was such a plaque there, it used to be at the crime site in the seventies and eighties, basically where they had been murdered, an enamel one, and it also disappeared, it wasn't there anymore (...) I don't remember it being there back in my day (...) The scouts erected one somewhere there in front of the house, an ordinary one (...) I don't know what happened to it" (M, ca. 40 years old, Markowa, July 2016).

There are many reasons for the lack, not only of more meaningful forms of remembrance, but also of structured and unified narratives of the Ulmas' deaths in the pre-2003 reminiscences of Markowa's residents.

Social notions (which developed after the war) of the motivations guiding those who helped the Jews were very important. The reasons for their decision to assist Jews were sought in their desire for profit. As two of our interviewees noted: "The Balawejders, who sheltered Jews, were like that, very industrious people, thrifty and anyway, they were doing some building work. This wasn't actually the case, but whenever they were putting something up, people were investigating whether they were getting rich on the back of Jews, but they really weren't profiting from Jews" (F and M, ca. 75 and 80 years old, Markowa, July 2016).

Quite possibly, the community was also reluctant to speak about the Ulmas' deaths because they were continuing, as it were, the convention surrounding the broaching of this subject they had adopted during the war. Essentially, keeping silent about wartime events, "not boasting" about helping others, and only mentioning cases of this kind in informal situations were still regarded as the best strategies to follow. After the war, the trials held in the 1950s could

450 Zbigniew Wawrzszczak, "Józef Ulma (1900-1944)”. In: Z dziejów wsi Markowa; Półćwiartek. Janusz (ed.), Rzeszów: The Society of Friends of Markowa, 1993, p 461.

451 The unveiling ceremony was extremely rarely remembered, or not at all, by our interviewees. 
also have influenced the villagers' reluctance to speak openly about the hiding of Jews during the war and the Ulmas' deaths. Much like in other regions of Poland, trials of people accused of collaborating with the Germans, colloquially known as sierpniówki, were being held in the region incorporated today into the Subcarpathian Voivodeship ${ }^{452}$. These criminal proceedings ${ }^{453}$ led to several people of local renown facing charges. They were accused of collaborating with the Germans by searching for Jews in hiding. The trials of Markowa's inhabitants became the main theme of an article written by Mateusz Szpytma, which was published when the museum was being built ${ }^{454}$. The author states:

I managed to trace the files of court proceedings against four inhabitants of Markowa and the prosecutor's investigation against another one, all of whom took part in the search for Jews ordered by the Germans in 1942 and took [those they found] to a provisional detention center in the commune administration building. It can be concluded on the basis of these documents that another 22 people with links to Markowa were also initially under suspicion, but the prosecutions of 20 of them, probably due to lack of evidence, were swiftly declined or their cases were dismissed. The cases of the other two progressed further but were dismissed ${ }^{455}$.

They were all acquitted, which does not however mean that they were innocent ${ }^{456}$. According to Grabowski and Libionka, there was hard evidence, notably

452 Sierpniówki were criminal proceedings brought against people tried under a decree issued by the Polish Committee of National Liberation (PKWN) on 31 August 1944 on "the appropriate punishment for fascist-Nazi criminals".

453 This topic is discussed in a number of works, including one authored by Barbara Engelking, Jan Grabowski and Dariusz Libionka titled Dalej jest noc. Losy Żydów w wybranych powiatach okupowanej Polski. Warsaw: Centrum Badań nad Zagładą Żydów, 2018.

454 Mateusz Szpytma, “Zbrodnie na ludności żydowskiej w Markowej w 1942 roku w kontekście postępowań karnych z lat 1949-1954.” Zeszyty Historyczne WiN-u, Vol. 40, 2014, pp. 39-66.

455 Szpytma M, Zbrodnie..., p. 15.

456 Grabowski and Libionka refer to Justice Władysław Piątkowski's justification of his sentence in a case in which four people accused of conducting a manhunt in the Rzeszów district were acquitted. The judge explained his decision as follows: "[I]t was similar to other acts committed by three-quarters of Polish society under the occupation. Should we [the judges - JG, DL] have prosecuted these actions in accordance with Articles $1 \& 2$ of the August 31, 1944 decree 42, we would have been forced to find several million Poles guilty, including at least tens of thousands of peasants, for acts identical with those of the accused, because the forcible participation of the peasants in manhunts occurred all over Poland." See Grabowski and Libionka, "Distorting and Rewriting the History", p. 52). For more on sierpniówki, 
the testimony of Jakub Einhorn, whose wife and child were killed next to "a provisional detention center" mentioned by Szpytma. However, the court chose to ignore his testimony and acquit the accused ${ }^{457}$.

The people we interviewed recollected the trials after the war. Evidently, it was still not easy for them to talk about them:

Yes, trials were held, but I don't know the details. Anyway, something certainly took place.

Someone even sat there [on the defendant's bench], I think, and was acquitted.

B. Of murdering Jews?

R. Not of murdering them, of looking for Jews. (M, ca. 82 years old, Markowa, July 2016)

Another factor that could have influenced the fact that the Ulmas' deaths were not remembered was that many similar events occurred in the immediate vicinity. The fact that the experiencing of death, irrespective of the accompanying circumstances, was a universal phenomenon must have exerted a crucial impact on the manner in which the importance of distinct cases was defined. It is worth adding that perception of the experiencing of death is hugely influenced by temporal distance. The experiencing of death is interpreted differently during a war than it is just after the war and differently again, sometime after the war ${ }^{458}$. As one of our interviewees noted, "But generally when it comes to topics of this type, it's not just about this family, this story. Not at all. Because other people died, for other reasons as well, as partisans, somewhere out there. In the countryside, the struggle was our daily bread, as it were" (M, ca. 40 years old, Markowa, July 2016).

The fact that the Ulmas were barely remembered could also have been influenced by the method of commemorating war victims developed in the Polish People's Republic (PRL) within the framework of state historical policy ${ }^{459}$. This political canon prioritized the remembrance of those who had fallen in battle over civilian victims of the war and occupation ${ }^{460}$. Even though political

see the chapter on Jedwabne in this volume. See also Alina Skibińska, “'Dostał 10 lat, ale za co?'. Analiza motywacji sprawców zbordni na Żydach na wsi kieleckiej w latach 1942-1944." In: Zarys Krajobrazu. Wieś polska wobec Zagłady Żydów 1942-1945, eds. Barbara Engelking and Jan Grabowski. Warsaw: Stowarzyszenie Centrum Badań nad Zagładą Żydów, 2011, p. 313-444; Zofia Wóycicka, Arrested Mourning. Memory of the Nazi Camps in Poland, 1944-1950. Frankfurt am Main: Peter Lang, 2013.

457 Grabowski and Libionka, "Distorting and Rewriting the History", pp. 45-53.

458 Marcin Zaremba, Wielka trwoga: Polska 1944-1947: Ludowa reakcja na kryzys. Kraków: Wydawnictwo Znak: Instytut Studiów Politycznych Polskiej Akademii Nauk, 2012.

459 Luczewski, Kapital moralny, p. 20.

460 tuczewski, Kapitał moralny, p. 68. 
policy in the late 1950s and early 1960s began to emphasize the martyrdom of the civilian population, ${ }^{461}$ the manner in which these victims were commemorated was subject to top-down assumptions held by the state that were still based on a heroic vision of fallen warriors. The Ulma family were never incorporated into the national canon. Furthermore, no one was willing to take the kind of measures that could make the Ulmas' story part of the national narrative.

The hierarchy of remembrance developed during the PRL period did not disappear after the changeover of power in 1989. This is clear from the publications local to Markowa created after the collapse of communism. The protagonists in these are often figures associated with the underground and resistance movements ${ }^{462}$. Janusz Półćwiartek's work $Z$ dziejów wsi Markowa (From the History of the Village of Markowa), which was published in 1993 through the efforts of the Society of Friends of Markowa, contains a short biographical entry for Józef Ulma that mainly focuses on his community and agrarian activities. The most emphatic accent is placed on his work as a rural photographer but a fair amount of space is also given to his work as a community worker who simultaneously functioned as an innovative fruit grower, gardener, beekeeper, and sericulturist. He is presented as one of the many figures who were important but not indispensable to the village. The deaths of Ulma and his family were recalled with a single sentence ${ }^{463}$.

\section{Family Memory and the Ulmas' Commemoration}

Wiktoria Ulma's family played a key role in the transformation of the narrative of the Ulma family. The first to contribute to the popularization of the family's history was Wiktoria Ulma's nephew, Stanisław Niemczak, who asked the Jewish Historical Institute in Warsaw in 1993 if the Ulmas could be honored with the Yad Vashem Martyrs and Heroes of the Holocaust Remembrance Authority's Righteous Among the Nations medal. He conceived the idea of putting forward the Ulmas for this honor after reading an article about the posthumous awarding of a similar distinction to some nuns ${ }^{464}$. He wrote in his letter of application:

461 Wawrzyniak, Veterans, Victims, and Memory, p. 197.

462 Janusz Półćwiartek (ed.), Z dziejów wsi Markowa. Rzeszów: Towarzystwo Przyjaciół Markowej, 1993.

463 Półćwiartek (ed.), Z dziejów wsi Markowa, p. 461.

464 Maria Szulikowska, "Nad grobem Ulmów wzeszło słońce”, Tygodnik katolicki niedziela, published 6 July 2018. Retrieved from http://www.niedziela.pl/artykul/131845/nd/ Nad-grobem-Ulmow-wzeszlo-slonce (last accessed 9 July 2018). 
I would be most grateful if you could inform me whether it would be possible to put forward a Polish family who sheltered Jews during the German occupation to be commemorated through the planting of a tree in Jerusalem (Righteous Among the Nations). A Polish family that took the name of Józef Ulma sheltered a Jewish family from Łańcut containing several members until they were murdered by the Germans in March 1944. At this point, the Polish family also died along with their young children. These people paid the ultimate price for the fact that they wanted to help others, because this price was their own lives and those of their young children. I will provide more details if it turns out that these people are deemed worthy of commemoration... ${ }^{465}$.

The Jewish Historical Institute reacted positively to Niemczak's question by sending him the necessary documents to complete. One of the most important witnesses to testify before the committee adjudicating on whether the Righteous Among the Nations medal should be awarded was Józef Ulma's brother, Władysław Ulma. In 1995, the Yad Vashem Martyrs and Heroes of the Holocaust Remembrance Authority posthumously awarded Józef and Wiktoria Ulma the Righteous Among the Nations medal ${ }^{466}$.

The huge success generated by the awarding of this title to the Ulmas encouraged the family of the murder victims to become even more actively involved in the commemoration of their forebears. Helena Majewska, Wiktoria's niece, marked the occasion of the Righteous Among the Nations title being awarded by painting the first portrait of the whole family ${ }^{467}$. After this, Stanisław Niemczak and his brother Antoni prepared a plaque containing information about the awarding of the title to the Ulmas and a copy of the family portrait Helena Majewska had painted. Both of these memory markers were placed on the Ulma's grave so "more people could learn about the Ulmas' honorary title" 468 .

It is worth adding that a few years later, Helena Majewska's painting became the official image of the family during the Ulmas' beatification process. Consequently, the portrait created by Wiktoria Ulma's niece became a "site of

465 Quoted after Maria Szulikowska, “Nad grobem Ulmów wzeszło słońce”, Tygodnik katolicki niedziela, 06.07.2018. Retrieved from http://www.niedziela.pl/artykul/131845/ nd/Nad-grobem-Ulmow-wzeszlo-slonce (last accessed 9 July 2018).

466 It is worth adding that several families from Markowa were honored in a similar way at the same time.

467 Maria Szulikowska, "Nad grobem Ulmów wzeszło słońce”, Tygodnik katolicki niedziela, published 6 July 2018. Retrieved from http://www.niedziela.pl/artykul/131845/nd/ Nad-grobem-Ulmow-wzeszlo-slonce (last accessed 9 July 2018).

468 Maria Szulikowska, "Nad grobem Ulmów wzeszło słońce”, Tygodnik katolicki niedziela, published 6 July 2018. Retrieved from http://www.niedziela.pl/artykul/131845/nd/ Nad-grobem-Ulmow-wzeszlo-slonce (last accessed 9 July 2018). 
memory" commemorating the Ulmas that appealed to both familial and religious memory. Furthermore, the family itself turned out to be an important memory actor creating and shaping public memory of the Ulmas. An active role in this process was also played by Urszula Niemczak, the daughter-in-law of Wiktoria Ulma's brother, who became involved in religious commemorations of the family. As she explained in one of the interviews she gave in 2018, when she first lived in her father-in-law's home, which had also been Wiktoria's family home, she did not realize how important the Ulma family were: "being there in that house, at my parents-in-law's, I also began to experience this warmth, only I maybe wasn't able to take it all in at the beginning, [take in] that it can be like that. But it was this kindness that I, as a stranger, received from my parentsin-law, because dad was Wiktoria's nephew, that aroused in me [the desire to] offer all of myself up to this love that is the most beautiful of gifts" ${ }^{369}$. Urszula Niemczak involved herself in the process of commemorating the Ulmas by distributing pictures and books among local residents and supporting the museum's construction. In 2016, during the museum opening, the President of Poland awarded Urszula Niemczak the Gold Cross of Merit for her "services to the cultivation of the memory of and dissemination of knowledge about Poles who rescued Jews and contribution to the creation of the museum in Markowa" ${ }^{\text {"470. }}$.

For years, members of the family have been constructing a narrative of the Ulmas portraying them as unsung heroes who were not able to sit quietly by when others were suffering harm. Wiktoria Ulma's nephew explained the family's motivations as follows in an interview given in 2018 during a symposium on the Ulma family, "why did they take them in? That's the question. In my view, for such human, humanitarian reasons. Basically, people in trouble had to be rescued. And the conditions they had were very convenient in a way because they lived away from the center. The house was surrounded by various bushes, it wasn't so easy to see what was happening around this house and that they were keeping Jews there. (...)". He went on to add: “To this day, I still wonder how so many people managed to squeeze into such a small house. It seems inconceivable today when homes can have several bedrooms, everyone has their own place, but there in this tiny house, there were seven of them, that is, six children, with their

469 “Sympozjum o Rodzinie Ulmów”, Radio FARA, 22 March 2018. Retrieved from http:// przemyska.pl/2018/03/22/sympozjum-o-rodzinie-ulmow/ (last accessed 9 July).

470 "Markowa: otwarcie Muzeum Polaków Ratujących Żydów im. Rodziny Ulmów”, Tygodnik katolicki niedziela, 17 March 2016. Retrieved from http://niedziela.pl/ artykul/21302/Markowa-otwarcie-Muzeum-Polakow (last accessed 9 July 2018). 
parents, that makes eight, eight Jews, and somehow they lived in harmony with each other for over a year" ${ }^{\prime 71}$. He also stressed that the Ulmas did not take money from the Jews for hiding them: "They were poor themselves and took in people who were even poorer" ${ }^{\prime 42}$.

However, a key role was played in the transmission of family memory to the public domain by a representative of the third generation, Mateusz Szpytma, who, as previously mentioned, was related to Wiktoria Ulma. It was he who created the first historical narrative of the Ulmas and initiated the construction of the Ulma Family Museum of Poles Saving Jews. It could be argued that it was Szpytma who became the guardian of their memory ${ }^{473}$. Two of the people we interviewed described his role as follows:

Mateusz Szpytma from the IPN, who is local to the area, he became interested because he also has family ties with the Ulma servants of God family, there is some family connection there, which is why he had a double interest, as it were. Firstly, a historical interest, and secondly, a family interest, so for this reason, he is such a promoter of this case and this testimony who wants to pass on the word about them. Later, he also supported the actions of the Church in this respect to ensure that this history would not fade into oblivion but go on instead to... (F \& M, group interview, Markowa, July 2016) Later, that monograph was confirmed by these well-known figures. Yes, and later the matter was publicized, I'd say, by Mateusz Szpytma. And what he did is to his credit. $\mathrm{He}$ was this driving force, this pioneer of learning about this family. (M, ca. 80 years old, Markowa, July 2016)

The involvement of the Ulma family's relatives has played and continues to play a vital role in the documentation of their history. It not only turned out to be

471 From an interview with Stanisław Niemczak, Radio FARA, 22 March 2018. Retrieved from http://przemyska.pl/2018/03/22/sympozjum-o-rodzinie-ulmow/ (last accessed 9 July 2018).

472 From an interview with Stanisław Niemczak, Radio FARA, 22 March 2018. Retrieved from http://przemyska.pl/2018/03/22/sympozjum-o-rodzinie-ulmow/ (last accessed 9 July 2018).

473 The notion of cultural memory (which had already begun to form in this case at a local level) may be evoked to justify the claim that this person had been appointed as a guardian of memory. Szpytma was by the same token regarded as a qualified person with broad knowledge and skills at his disposal who had been preparing a long time for his role. He had been tasked with designating, naming, and interpreting events, figures, or phenomena from the past; it was also he who possessed knowledge of the past and could determine which content was to be transmitted. See Jan Assmann, Cultural Memory and Early Civilization: Writing, Remembrance, and Political Imagination. Cambridge: Cambridge University Press, 2011. 
important that subsequent generations were making efforts to honor the murdered family but also that they were doing this at a particular time, a period, in fact, when the needs of completely different memory actors, including the Catholic Church, were beginning to come into play.

\section{The Beginnings of Religious Commemoration - 2003: The Watershed Year}

Although the Ulmas received the Righteous Among the Nations medal in 1995, the story was yet to be recognized at the time as an example of something exceptional. The Ulmas were not in fact the first residents of Markowa to join the ranks of the Righteous. Three years earlier, in February 1992, the Szylar family ${ }^{474}$ were similarly honored and subsequently, in August 1999, the Bar family ${ }^{475}$ also received the title. Quite possibly, the reason that the Ulmas did not attract greater interest in the village was that local residents who had helped Jews during the war were still alive at the time. Even so, the Ulmas' grave was increasingly visited by Jews arriving from Israel ${ }^{476}$.

The situation diametrically changed following events connected with the Catholic cult of martyrs that took place at the turn of the millennium. Following the beatification of 108 Second World War martyrs on 13 June 1999, the Polish Catholic Church began to search for and identify other people that could be honored in this way. Among those shortlisted for the second beatification process were the Ulma family. The moment that massively influenced the subsequent course of events was a sermon delivered by Fr. Stanisław Leja during Easter 2003. The parish priest from Markowa's church used this to ask his parishioners to help him find documents that could serve as evidence during the Ulma family's beatification process.

474 Information can be found on the Szylar family on the website of The Righteous Among the Nations. Retrieved from http://db.yadvashem.org/righteous/family.html?languag e=en\&itemId=4041109 (last accessed 9 July 2018).

475 Information on the Bar family can be found on the website of The Righteous Among the Nations. Retrieved from http://db.yadvashem.org/righteous/family.html?langua ge $=$ en\&itemId=4039634 (last accessed 9 July 2018).

476 Witold Półtorak and Grzegorz Bielec: “Znaczenie tragicznych wydarzeń historycznych dla turystyki na przykładzie rodziny Ulmów w Markowej”. In: Turystyka. Moda na sukces, Joanna Kowalczyk-Anioł, Marzena Makowska-Iskierka (eds.), Łódź: Uniwersytet Łódzki, 2012, pp. 135-146. 
Father Leja came from Grodzisko Dolne, a village that was home before the war to many Jews and contained a functioning ghetto during the occupation ${ }^{477}$. During his ministry, ${ }^{478}$ he was frequently reminded of the war murders. When he became Markowa's parish priest in 1993, he became interested in the Ulma family's story. It was through his own initiative and the support of the Diocese of Przemyśl that the Ulma family were included among the 122 people from the whole of Poland involved in the collective beatification process opened on 17 September 2003. For the local Catholic community, this was a special honor.

The diocesan stage of the beatification process concluded in 2008, at which point the files were passed on to the Diocese of Pelplin. The second stage of the process, which incorporated the whole of Poland, was concluded on 24 May 2011 in Pelplin, during a ceremonial Holy Mass presided over by Bishop Jan Bernard Szlaga. The documents from this stage were passed on to the Vatican, where further action was taken by the Vatican Congregation for the Causes of Saints. Shortly after we had completed our research, the Holy See's Congregation for the Causes of Saints issued a rescript, dated 31 January 2017, which approved a request, dated 31 January 2017, made by Archbishop Adam Szal, Metropolitan of Przemysł, thereby agreeing to withdraw the Ulma case from the collective beatification process. In an interview, the director for canonical affairs at the Diocesan Curia in Przemyśl, Father Roman Chowaniec, accounted for the bishop's actions as follows: "Bishop Adam Szal requested that the Congregation withdraw the Ulma family from the collective process because we are also noting greater interest in this family in Poland. One of the reasons for this is the foundation of the Ulma Family Museum of Poles Saving Jews in World War II in Markowa, near Łańcut"479.

477 See the article titled "History" on the Virtual Shtetl website managed by the Museum of the History of Polish Jews: https://sztetl.org.pl/en/towns/g/102-grodzisko-dolne/99history/137345-history-of-community (last accessed 9 July 2018).

478 The priest spent several years in the parish of Lutowiska. This village was mainly settled by Jews before the Second World War. During the war, a year before the German Army invaded this area (in June 1942), ca. 450 local Jews as well as Poles and 30 Romani were shot there. After the Jews were murdered, the wooden buildings around the market square and the synagogue, all of which had belonged to them, were burned down. Father Leja became involved in the commemoration of these events.

479 "Proces beatyfikacyjny rodziny Ulmów”, Niezależna, 9 March 2017. Retrieved from http://niezalezna.pl/95094-proces-beatyfikacyjny-rodziny-ulmow (last accessed 9 July 2018). 
In practice, this means that veneration of the Ulmas will be able to develop independently of the cult surrounding the other martyrs of the Second World War, thus highlighting the uniqueness of their example and the special recognition afforded to them by the Church. The very fact of the bishop issuing a decree triggering the commencement of canonization proceedings enabled each member of the Ulma family to be granted the official title of servant of God (Lat. Servus Dei). This has made it possible for the Ulmas to become objects of private veneration ${ }^{480}$.

It is worth adding that this is an exceptional situation, as there are no other examples in the history of the Catholic Church of a whole family, including children, being beatified. In an interview for the tvp.info website, a well-known Catholic features writer, Tomasz Terlikowski, offered the following explanation: "We have an example in the Russian Orthodox Church. The Orthodox Church canonized - because there is no two-stage process there - the whole Romanov family, Tsar Nicholas, his wife Alexandra and their five children, who were murdered by the communists. In the Catholic Church, however, we have two married couples that were beatified together - the parents of the 'Little Flower', Thérèse of Lisieux of the Child Jesus, that is, Louis Martin and Maria

480 The veneration of saints in the Catholic Church is defined by the Codex of Canon Law. As Father Henryk Misztal writes, two conflicting tendencies are evident in these rules. On the one hand, the law prohibits the granting of a public cult to people who have not been canonized, and therefore also to candidates whose beatification process is still ongoing. This explains why, as Father Misztal writes: "The diocesan bishop acting through his delegate is duty bound at the end of the canonization process to carefully inspect the servant of God's grave and the apartment where they lived or died as well as other sites where this candidate for beatification could be venerated. The aim [of this inspection] is to verify whether Urban VIII's regulations (of 1634) prohibiting the granting of a public cult to anyone whom the Holy See has not raised to the altar are being observed." See Henryk Misztal, Prawo kanonizacyjne według ustawodawstwa Jana Pawła II. Instytucje kanonizacyjnego prawa materialnego. Zarys historii procedury kanonizacyjnej. Postępowanie w diecezji i Kongregacji. Wzory pism i formularzy. Lublin-Sandomierz: Wydawnictwo Diecezjalne, 1997, p. 99. On the other hand, "the postulator should, by virtue of his office and the role he plays in the process (he represents the claimant), strive to develop a private cult for the servant of God, but always within the bounds of current practice within the Church and Congregation jurisprudence." See Misztal, Prawo kanonizacyjne, p. 100. Private veneration therefore prepares the ground for future Church-sanctioned public veneration, but should also comply with certain requirements. This explains why certain preparatory actions were taken in Markowa's church. 
Zélie Martin, and the Italian married couple, Luigi and Maria Quattrorocchi”481. If the Ulmas are beatified, this will be an event without precedence in the life of the Catholic Church, not just the Polish Church.

The commencement of the beatification process means that in the Ulmas' case, increasing attention is beginning to be devoted to the moment of death and how this was inflicted. According to the doctrine of the Catholic Church, a martyr's death should be the consequence of the martyr defending their faith (or virtue) and the persecutor should be acting out of hatred for this faith, a "good deed" or a particular virtue. At the same time, the martyr needs to accept the fact that death is being inflicted on them, display positive willingness to accept their martyrdom (implicitly as well), and maintain this state of mind until their death ${ }^{482}$. This explains the need during the canonization process to "affirm the heroic nature of the servant of God's virtues and canonically confirm that through their intercession at least one miracle was performed" 483 . The material response to these requirements in Markowa's church is a "book of graces", which contains entries from the faithful and pilgrims.

Although the final decision about which martyrdoms should be recognized is taken by the pope, the whole process is overseen by the Congregation for the Causes of Saints in Rome and the diocese to which the candidate belonged should prepare the basic documents. It is on the diocese's initiative that a postulator is appointed whose task it is to prove the heroic nature of the candidate's virtues (Lat. Positio super virtutibus) and collect the relevant documentation, including secret witness testimonies.

When the local residents we spoke to were asked to account for the exceptional nature of the Ulmas' case, most of them drew attention to the inspiration and actions of the Catholic clergy. As one of them noted (and the others spontaneously confirmed), the key figure turned out to be the parish priest from St Dorothy's Church in Markowa, Stanisław Leja. It was he who was remembered as the person who marked out the Ulma family as potential martyrdom candidates.

481 “Czy Ulmowie będą pierwszą rodziną wyniesioną na ołtarze?” TVP Info, 17 March 2017. Retrieved from https://www.tvp.info/29519122/czy-ulmowie-bedapierwsza-rodzina-wyniesiona-na-oltarze (Last accessed 9 July 2018).

482 “Sobór Watykański II, Konstytucja dogmatyczna o Kościele 'Lumen gentium.'”. 21 November 1964. In. Sobór Watykański II, Konstytucje Dekrety Deklaracje. Poznań: Pallottinum, 2002.

483 “Czy Ulmowie będą pierwszą rodziną wyniesioną na ołtarze?” TVP Info, 17 March 2017. Retrieved from https:/www.tvp.info/29519122/czy-ulmowie-bedapierwsza-rodzina-wyniesiona-na-oltarze (last accessed 9 July 2018). 
He went on to become involved in the search for evidence that would allow the episcopal curia to proceed with the beatification process:

... and this happened during the last parish priest's [ministry], the rescuing of this family from practical oblivion, such total [oblivion]. For sure, there was some awareness among their closest relatives, yet somehow this was absent among the community, there was no reflection on the fact that, in everyone's opinion, this should be remembered. On the other hand, Father Leja, Stanisław, who has passed on now, it was he who extracted this history from such content and went to such trouble, then with the episcopal curia too, and especially Father Stanisław Zygarowicz, our teacher, father confessor, he became involved in these matters, uncovered those testimonies. This was what was passed on to him. And then this matter began to progress [helped on by] this element of what was now wider interest. (M, ca. 40 years old, Markowa, July 2016)

It is clear from what our interviewees told us that the key event in this case turned out to be the parish priest appealing to Markowa's residents (especially his parishioners) to help him and get involved in the whole enterprise. The key moment was the Easter Mass in 2003, during which the Ulmas were spoken of as potential martyrdom candidates (M, ca. 40 years old, Markowa, July 2016). This was followed by hearings, locally known as confessions, conducted by priests that were meant to document the beatification process. As one of our interviewees recalled, "I was at church at the time and the priest made it known that [Józef Ulma's case] was being checked and the parishioners should give their views on whether there were any impediments. Because that's how it's done, the first thing to be checked is whether there are any impediments" (M, ca. 40 years old, Markowa, July 2016).

Although the hearings themselves and their content were secret, the fact that they were being conducted at all turned out to be extremely significant. These procedures led to the Ulmas' story being discussed within what was then a new context - what had once been only a local event that was both exceptional and terrible had now taken on a religious dimension. During our research, the family were already recognized as servants of God, and their beatification was being prayed for as follows: "Eternal Father, who sent your own Son into the world to give up his life for us out of love, we ask that you verify [the Ulmas' candidature]; may testimony to the heroic love between husband and wife Józef and Wiktoria and their Children, who gave up their own lives to rescue persecuted Jews, bear the fruits of salvation and fill the world with Your peace" ${ }^{\prime 44}$.

484 “Modlitwa o beatyfikację Józefa i Wiktorii Ulmów z dziećmi”. Retrieved from: http:// mtrojnar.rzeszow.opoka.org.pl/swieci/ulmowie/ (last accessed 9 July 2018). 
The possibility of the villagers obtaining their own blesseds, who would be commemorated in the official liturgical calendar, is also perceived as testament to the exceptional nature of a local community that has not only become heir to but also a depository of memory of the Ulmas. As Archbishop Józef Michalik said during a ceremony commemorating the seventy-fourth anniversary of the Ulma family's murder: “The Ulmas were the pearl in Markowa's crown; this was an exceptional family. Simple people, it would appear, like all of us, how holy they are. After all, they are saints. Their willingness to demonstrate their faith in the Lord God needs to be respected. This duty falls to today's inhabitants of Markowa. This is not an act of mercy, this is a duty, a privilege that God has given unto you. You need to accept and develop it" ${ }^{385}$. Comments made by other interviewees indicate how important the religious honoring of the Ulmas turned out to be for representatives of the local community: "I tell you what, Markowa would be very proud and happy because we [would] have our own advocates in heaven. I'd like to live to see that moment" (M, ca. 45 years old, Markowa, July 2016).

While the beatification process is still in progress, initial preparations are being made in a side aisle of Markowa's church. Once the process has reached a positive conclusion, this aisle is to be dedicated to the Ulmas. While we were conducting our research in the church, all it contained was a painting depicting the Ulmas, servants of God (Fig. 4.2). It is worth adding that since 2004, the site where the Ulmas died has become a component of a religious ritual, the Lenten Stations of the Cross procession (Fig. 4.3). One of Markowa's residents noted:

This Lent we attended such a Stations of the Cross [procession]... This was connected with Lent, with the celebration of the Stations of the Cross, so we planned the route there for this and the Stations of the Cross took place there. Also, this is the place where that site is marked where they lived, experienced their history, including the last moments. Also, annually now, ceremonies connected with this testimony of the servants of God are held, right now, of the Ulma Family, servants of God; there's also this act of prayer, which also enables us to come in touch with that sacrificial love of people who died then along with their children. Also, this is a grand testament, which I think offers inspiration here and [allows] the community somehow to reflect on this life that is supposed to be not only the experiencing of daily reality, but also

485 “W Markowej uczczono 74. rocznicę śmierci rodziny Ulmów”, Niedziela Przemyska, 22 March 2018. Retrieved from http://www.niedziela.pl/artykul/34493/W-Markowejuczczono-74-rocznice-smierci (last accessed 9 July 2018). 


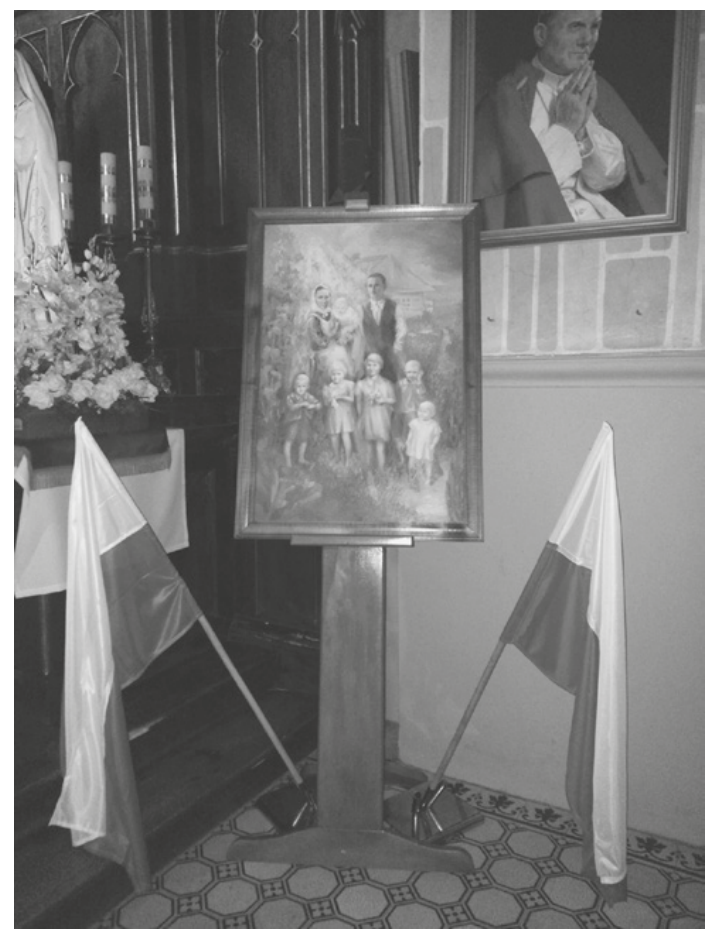

Fig. 4.2: Painting of the Ulma family located in the left nave of St Dorothy's Parish Church in Markowa. Photograph by Marta Karkowska.

a testimony for others, so this is what happened in the Ulma family. ( $M$, ca. 40 years old, Markowa, July 2016)

All these actions show how the Ulmas are being incorporated into the prevailing religious context and how very important this is for the manner in which the family are thought or spoken of. Furthermore, once this family from Markowa are incorporated into the Catholic martyrdom narrative, their fate begins to form part of a universally familiar religious message that is one of the elements of faith.

\section{Between Religious and Secular Remembrance}

Conferring the title of servants of God on the Ulma family has also led to the creation of the first secular remembrance practices. The need has also arisen to source new documents and information from the circumstances of the family's 


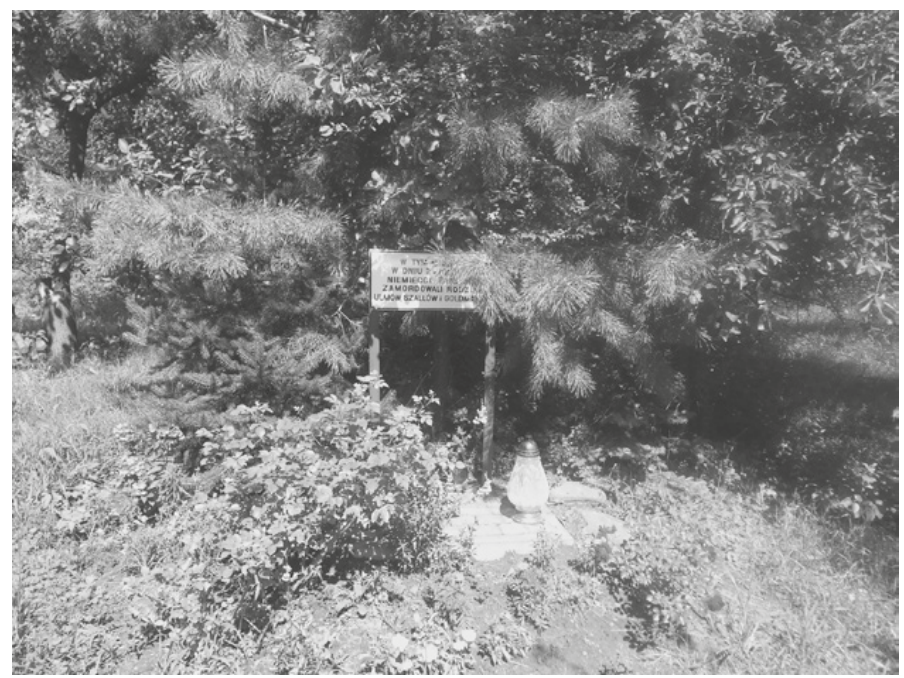

Fig. 4.3: The site where the Ulmas' house once stood and where they and the Jews they were hiding were killed on 24 March 1944. Photograph by Marta Karkowska.

death. There are in fact some discrepancies in how various members of the local community describe the course of events, as one of our interviewees made clear:

However, there are also matters of discrepancy. Because the village leader was not at the murder. Nevertheless, some tell it differently, but he was not there. He was summoned when it was all over. And there are also two versions; it's true the Jews were [killed] first, but [some say that] the children were next and then the parents. The second version [is that] the parents were first, then, after some consultation, the children. What really happened? There's a question mark over that. [...] She [one of the witnesses] says that the children were killed first, and then the Ulmas. [...] What really happened is probably not important, but nevertheless [I am curious about] what the order of this was, of this event. (M, ca. 82 years old, Markowa, July 2016)

The singling out of the Ulmas as martyrdom candidates has begun to remind local residents of the fact they were earlier rewarded the Righteous Among the Nations medal. The decision by the Yad Vashem Institute in Jerusalem to award the Ulmas this title has begun to be treated as evidence confirming the importance of their death and legitimizing the need to take further steps to commemorate them. As one of our interviewees stated:

... if this cause is to be commemorated, it is extremely important that they are certified, as it were - that's an ugly word, but they are certified, as it were, by both parties, as it 
were, to this discourse. I don't know if this should be divided into sides, or not divided, but in the sense of [there being] a Jewish and a Polish side, because the Righteous Among the Nations is there and the beatification process is here, so it's harder to obtain more clarity, as it were, on the situation, because the Jews are really afraid and I understand that and really appreciate that. The Jews are very afraid of becoming involved in any causes that are doubtful. [Their dilemma is whether] to come to some opening of a memorial dedicated to someone who we regard as a Pole who rescued Jews and no one knows whether we have invented someone or whether he really did rescue someone; there are always doubts. When we have the Righteous Among the Nations medal, that means that they have been checked in all manner of ways. In this case, in fact, this was all checked. (M, ca. 40 years old, Markowa, July 2016)

The commencement of the beatification process also gave rise to the first publications examining the circumstances of the Ulmas' deaths: “yes, something was being done to this end, but it wasn't yet the case that some publications were coming out. It wasn't really until 2003 or 2004 that the more official ones began to come out, because earlier there were no photographs of [the family] to make the [publications] accessible" (M, ca. 82 years old, Markowa, July 2016).

Szyptma quickly found support among the representatives of the local Society of Friends of Markowa, the local authorities and, importantly, the local community as well. As one of the society members noted:

And then Dr Mateusz Szyptma came to us. Being the older generation, we didn't know him. [...] Anyway, we listened to what he wanted to tell us. And he told us then that the next year, 2004, would be the sixtieth anniversary of that terrible murder of the Ulma family. And it would be fitting to commemorate this anniversary in some way. Anyway, these words of his dropped on fertile ground. The society was more than willing to agree to the erection of a memorial. The authorities were even a little worried, the commune authorities of course, because it somehow turned out that in the budget, it was March, it was the case at the time that the budget had already been set, there wasn't any money. Anyway, the society decided with the village council to organize a collection in the village for the memorial. And that's what happened. The local council went around from door to door. (M, ca. 82 years old, Markowa, July 2016)

However, the erection of the memorial turned out to be no easy task. There was some disagreement over its meaning and purpose. In the end, it was agreed that it should display a symbolism that, as one of our interviewees explained, was meant to resolve these doubts. (Fig. 4.4):

On the front are two mighty boulders and one boulder is suspended from the top. The idea was for it to be an altar table. [...] However, while it was being built, or even before its construction, there was such a long version of the explanation of the fact that this is the letter pi, this is such an infinite letter. The point was that memory of this family would be infinite. If you look at it from the front, you will clearly see that this is the letter 


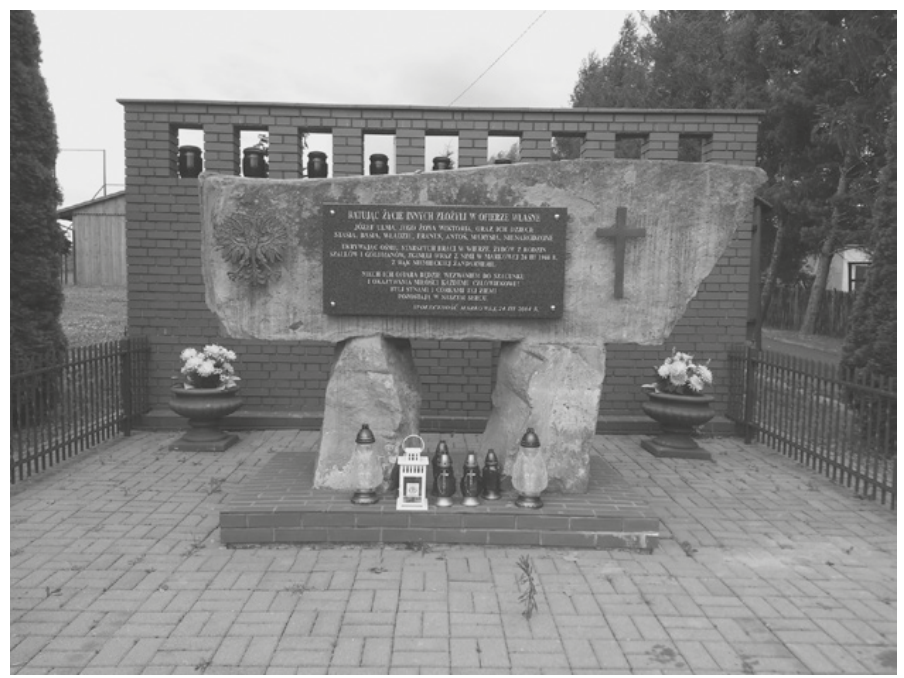

Fig. 4.4: The Ulma family monument in Markowa. It was founded by the villagers and erected next to the Village of Markowa Skansen (see picture). In 2017, the monument was moved several hundred meters further on to the Orchard of Remembrance. Photograph by Dariusz Bogumił.

pi. But we never explained - I'm speaking about this now for the first time - we didn't explain, or only amongst ourselves, what we were building there and what the conception was. And the point the whole time was not to speak [about the conception] and just let everyone interpret it in their own way. [...] And we wanted this cross and eagle, I also had to disclose this, to emphasize that these are Catholics. (...). It was necessary to convince people a little that this was a worthy family, that they should commemorate them. [...] this cross and eagle were added to emphasize that this was a family that was Catholic and Polish. (M, ca. 65 years old, Markowa, July 2016)

The history of the memorial's erection shows that this was not an easy process and by contrast with the religious commemoration, which did not provoke any polemics or debates, certain differences of opinions emerged in the case of the secular monument. However, these were resolved through the efforts of local leaders who managed to prevent them from turning into open conflict. They proposed that the memorial's symbolism should allude to the "Catholic Pole". This was meant to aid the incorporation of the Ulmas' story into a broader national and religious discourse. The Markowa example shows what a significant role local leaders play in the memory negotiation process and also that the actions they take determine whether this process proceeds smoothly rather than 
being disrupted by disagreement and to what extent the consensus that is eventually negotiated is accepted by the local community.

The local community also regarded the separate commemoration of every member of the family as something important enough to be worth pursuing. As a result, nine urns were placed behind the monument - two large ones symbolizing Józef and Wiktoria and six smaller ones symbolizing each child in turn. The smallest urn symbolizes the unborn child. Representatives of the local Catholic pro-life movement requested that it be placed there, accounting for their actions as follows: "We would consider it to be a citizen. That's why every Ulma - Józef, Wiktoria, the children and this tiny unborn child - has their place there. That's why there are as many as there are" (F, ca. 65, Markowa, July 2016).

At the same time, however, it was decided that the inscription on the commemorative plaque would be prepared by historians from the Institute of National Remembrance. This decision was based on the belief that they were better equipped to provide a factual explanation of the event the monument commemorates. The memorial bears the following inscription: "While rescuing the lives of others, they sacrificed their own. Józef Ulma, his wife Wiktoria and their children: Stasia, Basia, Władziu, Franuś, Antoś, Marysia, ${ }^{486}$ the Unborn Child, through hiding eight elder brothers in faith, Jews from the Szall and Goldman families, died with them in Markowa on 24 March 1944 at the hands of the German military police. May their sacrifice be a testament to respect and the expression of love toward every human being! They were sons and daughters of this earth. They will remain in our hearts. The Markowa community, 24 March 2004".

This plaque inscription shows which issues were regarded in 2004 as being crucial for comprehending what had happened in 1944. First, the actual act of hiding Jews is highlighted and interpreted as "sacrificing one's life" for the benefit of others, in this case "elder brothers in faith". Second, rather than the Ulma family being commemorated, every member of this family - including an unborn child - is commemorated separately. The individualization of the Polish victims by mentioning them by name and the collective presentation of the Jewish victims shows the hierarchy of the victims the monument is commemorating. At the same time, the words that follow offer a clear interpretation

486 The diminutive forms of the children's names have been engraved on the memorial, lending them the character of vivid, affectionate, everyday language and making the memorial a less official and more private site of memory. 
of the meaning of the Ulma family members' deaths. They are meant to serve as an example to others, a lodestar worthy of emulation.

The memorial unveiling ceremonies were an important event in Markowa life. They not only involved representatives of the local authorities and hierarchs of the church, but also a Jew rescued by a family from Markowa. As one of our interviewees recalled, "On 24 March 2004, the memorial was consecrated by Archbishop Józef Michalik. A grand ceremony, and this ceremony was also attended by Abrahan Segal - A Jew who was rescued by the Cwynar family in Markowa. That ceremony was also grand" (M, ca. 45 years old, Markowa, July 2016).

The memorial erected in 2003 performs a dual function. On the one hand, it is perceived as a monument commemorating the Ulma family within the secular domain and evidence that the village remembers this family and its history. On the other hand, it is a place at which visitors, regardless of professed religion, can pay homage to the murder victims. As one of our interviewees stated, "Jews visit, they can approach this memorial and remember the Ulma family there in a prayerful manner, even more so than at a cemetery. Because at a cemetery, there are restrictions, it is Catholic [...] However, they meditate for so long by the memorial. A memorial is also the kind of place where one can speak openly as well. At a cemetery, it's different, people could be treated differently, made an example of, or something. A memorial is such a good place" (M, ca. 40 years old, Markowa, July 2016).

For Markowa's inhabitants, the monument's erection came to express their secular local memory of their compatriots, but also became a source of pride for those visiting the site. It is increasingly to here that tourists are directing their steps. Being a secular site, it is particularly important for people visiting from Israel, whose numbers grew considerably after $2004^{487}$.

The memorial's erection led to other acts of local remembrance. In 2006, on the day before the forty-second anniversary of the murder, a combined primary and middle school in Markowa was renamed The Ulma Family Servants of God School. As Anna Kątnik, the head of the middle school in Markowa says, "For our children, it is important that the patrons of their school are people who are

487 Półtorak and Bielec, “Znaczenie tragicznych wydarzeń historycznych dla turystyki na przykładzie rodziny Ulmów w Markowej.” In: Turystyka. Moda na sukces, eds. Joanna Kowalczyk-Anioł and Marzena Makowska-Iskierka. Łódź: Uniwersytet Łódzki, 2012, pp. 135-146; Potocki, Andrzej. Żydzi w Podkarpackiem. Rzeszów: Wydawnictwo Libra,: 2004, p. 92-105. 
neighbors of their families" ${ }^{\prime 48}$. It is worth adding that these ceremonies involved representatives of the Chancellery of the President of the Republic of Poland, the Minister of Culture, Kazimierz Jaworski, chairman of the IPN, Janusz Kurtyka, and over 40 schoolchildren from Jerusalem ${ }^{489}$. This event showed that the Ulmas' story is beginning to become an important part not only of local history, but also of Polish political policy.

\section{The Museum Memory Project and National Memory of the Ulmas}

The idea to build a museum surfaced almost immediately after the unveiling of the memorial and initially only related to the Ulma family. As one of our interviewees mentioned, "this was not supposed to be a hall of memory, only a genuine museum. But also not one devoted to Poles who rescued Jews. Only devoted to the Ulma family [...] the IPN book about Poles who had rescued Jews came out in Rzeszów [...] as this topic has been researched, it should be devoted to this region, as it were, to those Poles who are here" (M, ca. 40 years old, Markowa, July 2016).

Mateusz Szyptma instigated the idea, but also brought the whole venture to realization. As one of our interviewees noted, "As a matter of fact, such a situation has really emerged that this Dr Mateusz Szpytma, for whom the Ulmas are family, he has become involved in this. He got the priest, Leja, who is no longer alive, interested and somehow together, [Leja] from the church's side, beatification, and so on, and Mateusz from the historical academic side. And then things really got off the ground. And everything was somehow carried on a wave, yes, for now it has become, let's say, fashionable - in quotes - so it's been a success" (M, ca. 45 years old, Markowa, July 2016).

As the museum in Markowa's website records, the idea to create the Ulma Family Museum of Poles Saving Jews in World War II (MPRŻ) in Markowa officially appeared at the end of $2007^{490}$. The decision to build the museum was

488 Anna Gorczyca, "Gimnazjum i szkoła podstawowa w Markowej noszą imię Sług Bożych Rodziny Ulmów”, Gazeta Wyborcza (Rzeszów), 24 March 2006. Retrieved from http://rzeszow.wyborcza.pl/rzeszow/1,34962,3234743.html (last accessed 9 July 2018).

489 Szarek and Szpytma, Rodzina Ulmów. Przejmująca historia, p. 89.

490 For more information, see the official website of the Ulma Family Museum of Poles Saving Jews during the Second World War (MPRŻ). Retrieved from https:// muzeumulmow.pl/pl/muzeum/o-muzeum/ (last accessed 9 July 2018). 


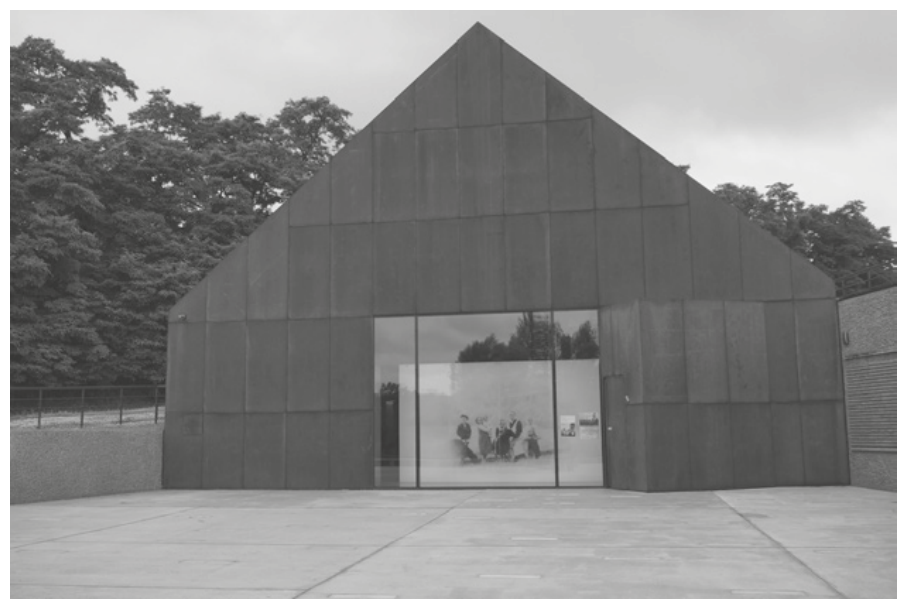

Fig. 4.5: The Ulma Family Museum of Poles Saving Jews in World War II in Markowa. Photograph by Dariusz Bogumił.

taken by the Subcarpathian Voivodeship Regional Council in June 2008, a site for its construction was granted by the Commune of Markowa Local Council, and the new administration unit was to be part of the Castle Museum in Łańcut. The MPRŻ's construction took place from October 2013 to October 2015. The museum was opened on 17 March 2016 (Fig. 4.5).

The opening ceremonies began with Jewish and Christian prayers at the cemetery in the village of Jagiełła, where the Jews murdered with the Ulma family were laid to rest. Afterwards, similar prayers were said in Markowa, where the Ulma's grave is located. The prayers were said by the Przemysł Metropolitan Archibishop Józef Michalik and Michael Schudrich, Poland's chief rabbi. At St Dorothy's Parish Church in Markowa, a Holy Mass was also celebrated, during which a homily was given by one of the most important dignitaries in the Catholic Church, President of the Polish Episcopal Conference, Archbishop Stanisław Gądecki. The ceremonies were also attended by an envoy from the Vatican, Bishop Carlos Azavedo ${ }^{491}$.

491 "Markowa: otwarcie Muzeum Polaków Ratujących Żydów im. Rodziny Ulmów”, the Niedziela Catholic weekly, 17 March 2016. Retrieved from http://niedziela.pl/ artykul/21302/Markowa-otwarcie-Muzeum-Polakow. (Last accessed 9 July 2018). 
The museum's inauguration was also attended by the President of Poland, Andrzej Duda, with his wife Agata Kornhauser-Duda and serving ministers. During the evening ceremonies, Duda and his wife planted a fruit tree in the Orchard of Remembrance, which was to be created next to the museum. The president gave a speech in which he reminded his audience that Poland was a country where helping Jews was punishable by death ${ }^{492}$. He went on to call Markowa "a grand place for the history of the Republic of Poland, for it manifestly exemplifies why we, a Polish people, can feel worthy" ${ }^{\text {"993 }}$. He also presented state honors to 54 people who "did not close the doors of their homes to Jews" during the German occupation ${ }^{494}$. This was followed by a multimedia show broadcast on national public television that offered an interpretation of the Ulma family's fate. The visualization was accompanied by a soundtrack that evoked episodes from the life of Markowa's residents ${ }^{495}$.

The museum itself is a small modern building on sloping terrain. Its architects intended its form, which symbolizes a country cottage cutting through the slope like a ploughshare, to underscore the tragic history of the museum's patrons.

492 The President said that when saving Jewish fellow citizens, they were well aware of the risk they were taking. "A large risk, the risk of death, because helping Jews here in occupied Poland was punishable by death like nowhere else in the world and this sentence was ruthlessly executed, as it was here", quoted from the article "Prezydent Duda otworzył Muzeum Polaków Ratujących Żydów”, PAP, 17 March 2016. Retrieved from http://www.pap.pl/multimedia/news,488865, prezydent-duda-otworzyl-muzeumpolakow-ratujacych-zydow.html (last accessed 9 July 2018). This is not in fact true because Poland is not the only country where people were killed for providing help to Jews. Similar legislation operated in Serbia and Ukraine. "Kara śmierci za ukrywanie Żydów - wywiad z prof. Andrzejem Żbikowskim”, an interview given to Waldemar Kowalski by Prof. Andrzej Żbikowski, portal dzieje.pl, 15 October 2016. Retrieved from http://dzieje.pl/aktualnosci/kara-smierci-za-ukrywanie-zydow-wywiad-z-profandrzejem-zbikowskim (last accessed 9 July 2018).

493 Address by the President of Poland at the opening ceremony of the Ulma Family Museum (official English version), 17 March 2016, Retrieved From: http://www. president.pl/en/news/art,123, address-by-the-president-of-poland-at-the-openingceremony-of-the-ulms-family-museum-.html (last accessed 9 July 2018.).

494 “'Kto sieje i podsyca antysemityzm, depcze po grobie rodziny Ulmów’. Prezydent na uroczystościach w Markowej”, TVP Info, 17 March 2016. Retrieved from https://www. tvp.info/24472955/kto-sieje-i-podsyca-antysemityzm-depcze-po-grobie-rodzinyulmow-prezydent-na-uroczystosciach-w-markowej. (last accessed: 21 June 2018).

495 http://infopodkarpacie.pl/wiadomosci/pokaz/1950, uroczyste-otwarcie-muzeumpolakow-ratujacych-zydow-im-rodziny-ulmow-w-markowej-zdjecia (last accessed: 21 June 2018). 
A relatively small area of $500 \mathrm{~m}^{2}$ includes a research laboratory, a lecture hall, and an exhibition space. In the center is a $5 \times 8 \mathrm{~m}$ glass cuboid which is a 1:1 scale model of the Ulmas' house ${ }^{496}$. According to the Museum's website, ${ }^{497}$ the form of this austere minimalist structure alludes to a primitive country house. Inside, the floorplan of the Ulma family's original home has been reconstructed, a collection of family mementos is on display, and there are a number of multimedia installations - for example, a family album in which photos are projected. As Florian Peters, a historian who has analyzed this exhibition, wrote, "This illuminated glass structure is surrounded by a rather dark room with exposed concrete walls and exhibition panels made from black metal, which makes for a somewhat sacral atmosphere" ${ }^{\text {498 }}$.

The exhibition hall in which the permanent exhibition is presented consists of a single space. Nearly all the exhibits have been described in three languages: Polish, English, and Hebrew. According to the English version of the museum's website, "To a large extent, [the exhibition] is based on research carried out by the Institute of National Remembrance of the Republic of Poland - the local branch in Rzeszów, from which the album 'Poles Rescuing Jews in the Rzeszów Region in the Years 1939-1945’ by Elżbieta Rączy and Igor Witowicz, published in 2011, resulted. Another source of information for the exhibition constituted research conducted by Mateusz Szpytma" ${ }^{399}$.

The exhibition presents archival materials (printed matter and photographs, but also documentary films). It is worth stressing that the story of the Ulmas that is presented in the glass cuboid reconstruction of their home is mainly told by means of authentic objects and photographs that have survived the family. As Florian Peters writes, "One of the most touching exhibits relating to this act of charity is a Bible used by Józef and Wiktoria Ulma, on the pages of which they

496 The original house has not survived.

497 For more information, see the Ulma Family Museum of Poles Saving Jews in World War II’s (MPRŻ) official website. Retrieved from: https://muzeumulmow.pl/pl/ muzeum/o-muzeum/ (last accessed 9 July 2018).

498 Florian Peters: "Towards a Balanced Tribute to the Polish Righteous? The Ulma Family Museum of Poles Saving Jews in Markowa". In: Cultures of History Forum (8 December 2016), Retrieved from http://www.culture-of-history.uni-jena.de// exhibitions/poland/towards-a-balanced-tribute-to-the-polish-righteous-the-ulmafamily-museum-of-poles-saving-jews-in-markowa/ (last accessed 9 July 2018).

499 For more information, see the Ulma Family Museum of Poles Saving Jews in World War II’s (MPRŻ) official website. Retrieved from: https://muzeumulmow.pl/en/exhibition/permanent-exhibition/ (last accessed 9 July 2018). 
had marked the passage on the Good Samaritan from Luke". By contrast, the rest of the exhibition (which contains information about Poles and Jews living in the Subcarpathian region, the German occupation before 1939, Poles rescuing Jews, Jewish hideouts and refuges, Poles murdered for assisting Jews, and the period after the war) only includes a few authentic artifacts. Most of it is based on documents, archival photographs, and photocopies of prints dating from this period. This decision to create this contrast was not taken by chance. The objects belonging to the Ulmas make their story more immediate and intimate, while the documents testify to the museum narrative's accuracy and objectivity ${ }^{500}$.

In the lecture hall, temporary exhibitions are presented, talks are given, and educational projects of various kinds are implemented. Importantly, the guests at these events are often actually local residents, as we would have the opportunity to observe during our research.

In front of the museum building is a small square with illuminated plaques containing the names of Poles murdered for assisting Jews. The center of the square is occupied by a stone slab containing an inscription which is a memorial dedicated to the memory of both the Jewish victims of the Holocaust and the anonymous Poles who helped them. A wall next to the museum building contains plaques containing the names of inhabitants of the Subcarpathian region who rescued Jews during the occupation. The aforementioned Orchard of Remembrance is also next to the museum. The fruit trees that have been planted there allude to the Garden of the Righteous at Yad Vashem, but also remind visitors that fruit farming was one of Józef Ulma's passions. In 2017, plaques were placed among the trees that contained the names of the 1,500 places from where Polish Righteous Among the Nations came $e^{501}$.

The architectural design for the museum was created by Mirosław Nizio's studio, which also designed the Mausoleum in Michniów and part of the Warsaw

500 In her interpretation of the permanent exhibition in the Markowa museum, Zofia Wóycicka drew different conclusions about the manner in which it presented the Ulmas. In her view, the fact that the Ulmas were placed at the end of the exhibition equated to their story being of secondary importance, just one of many examples of assistance being provided to Jews. See Zofia Wóycicka, "Global Patterns, Local Interpretations: New Polish Museums Dedicated to the Rescue of Jews during the Holocaust", Holocaust Studies: A Journal of Culture and History, Special Issue: Disputed Holocaust Memory in Poland (upcoming).

501 Krzysztof Kuchaj, "Przy Muzeum w Markowej powstał Sad Pamięci”, TVP 3 Rzeszów, 15 October 2017, Retrieved from https://rzeszow.tvp.pl/34407236/przy-muzeum-wmarkowej-powstal-sad-pamieci (last accessed 9 July 2018). 
Uprising Museum as well as others places important for national memory, such as the Museum-Site of Memory in Bełżec or the Gross-Rosen Concentration Camp Stone Hell.

The concept for the museum evolved over time. Initially, the museum was planned as a regional institution. However, once the work had started, the decision was taken, with the support of the IPN, to make the museum a state institution $^{502}$. Following this decision, the purpose of the museum as an institution commemorating the Ulma family became to "demonstrate the heroic attitudes of Poles who were assisting Jews during the German occupation, risking their lives and those of their families" ${ }^{\prime 503}$. From then on, rather than being a purely local cultural institution, it became the first institution in Poland to "engage with the subject of the rescuing of the Jewish population on the occupied Polish lands during the Holocaust". As a result, the Ulmas' story became an important component of the debate on relations between ethnic and Jewish Poles and issues relating to the situation Poles and Jews found themselves in during the Second World War.

The museum attracted over 20,000 guests (M, ca. 40 years old, Markowa, July 2016) during its first four months of operation, which was regarded as a great success, especially given the fact that Markowa itself is rather out of the way and takes some time to get to. During our research, both individuals and organized tour groups were eager to visit the museum. Guests also arrived there from other countries, mainly Israel. As of 2012, the records at the Markowa Commune Cultural Center were indicating that it was this last group that was most interested in the Ulmas' story ${ }^{504}$. The opening of the museum and the popularization of the Ulmas' story not only led to a rise in the number of groups from Israel, but the museum was also increasingly visited by consecrated persons and groups of pilgrims. As one of our interviewees noted, "groups are visiting, especially now, when this beatification process is still going on, [they come] from different places, even more so now the museum has been opened. Now, as a matter of course, they are not only going to the museum or the memorial, but also coming to the church, so it's as if they're conflating this issue of remembering those who died with the servants of God, the Ulmas. Well, in any case, this inspires them to go to the church as well” (M, ca. 40 years old, Markowa, July 2016).

502 For more details on the museum history see Wóycicka, "Global Patterns, Local Interpretations".

503 For more information, see the Ulma Family Museum of Poles Saving Jews in World War II's (MPRŻ) official website. Retrieved from: https://muzeumulmow.pl/pl/ muzeum/o-muzeum/ (last accessed 9 July 2018).

504 Półtorak and Bielec, "Znaczenie tragicznych wydarzeń historycznych”. 
In 2016, plans were afoot to accommodate more groups by creating a new square forming part of the Orchard of Remembrance (also known as the Orchard of the Righteous). In 2017, the memorial the local community built in 2004 was moved to that square, where large groups of people are able to join in paying homage to the Ulmas in front of the memorial. While no objections were raised to the idea of moving the memorial a few hundred meters from its original site, the Nizio Design International architecture studio's idea to preserve the slab itself but integrate it into a completely new architectural form met with resolute opposition from Markowa's residents. It turned out from one conversation after another we had with the villagers that it was important to them that there were no changes made to a memorial that was widely recognized as having been created on their initiative, from their own funds and as a result of their own efforts. One of our interviewees characterized Mirosław Nizio's studio's plans as follows:

He wanted to dismantle this monument, that one there, because it was supposed to be here in this orchard and here, as if there would be no great controversy. But he only wanted this for a new monument [...] I knew how the village would have reacted. Not only because I protested, that I was personally against this, but I knew that this would provoke protests in the village and be extremely badly received [...] It has to be moved, the monument is supposed to be moved. Any modifications need to be minimal. I understand that the clinker brick was not to his liking [...] there won't be any clinker [...] There'll be urns. There'll be a wall like that one, but it'll be constructed from concrete rather than clinker. (M, ca. 40 years old, Markowa, July 2016)

The studies conducted in 2016 to determine the impact of the memorial being moved and its form being changed provoked animated discussion in the village. Importantly, however, this small conflict had little effect on villagers' positive disposition and attitude toward the museum. They assured us that they were still eager to visit whenever they could and treated it as the outcome of their own efforts and enterprise, a place that was a source of both pride and prestige for Markowa. As one person noted, "[This] friendly attitude [towards the museum] is clear to see. It was nothing like that, I didn't encounter, and I don't think anyone else did either, anyone, even individuals, displaying any aversion here" (F, ca. 35 years old, Markowa, July 2016).

When in 2017, the memorial was moved to the square in front of the museum, the clinker wall on which urns were being placed was replaced by a lower, concrete one. Such an approach enabled the preservation of the concept, so important to Markowa's residents, of each member of the Ulma family being separately commemorated. As a result, the moving of the monument failed to provoke a conflict between local and state remembrance practices. 


\section{The Meaning of Material Repositories for Memory of the Ulmas}

When seeking the reasons for the success of a local history that over a very short period of time became a component of the national and state memory discourse, the role of the material legacy left by the Ulmas should not be forgotten. During the interviews we conducted, many people pointed out that Józef Ulma had left behind many mementoes providing details of his family history. The Ulma family members who are still alive have kept objects that once belonged to the murder victims, which include furniture and books as well as photographs. The objects and everyday items that were being stored in their attics have turned out to be unique mementoes of the deceased that the museum has used as artifacts, making its narrative personal and authentic.

The most important of these mementoes turned out to be the photographs Józef Ulma took ${ }^{505}$. Those he took during the harvest festival and other rural festivities have been used on many occasions before by such organizations as the Society of Friends of Markowa to tell the village's history. However, after 2003, these photographs lost some of their significance as the family photographs became more important. The latter not only made it possible to recreate images of each member of the family, but also document their life as they went about their daily activities. Many of the photographs depict the children and Wiktoria Ulma posing for the lens both in their house, in front of it and in their garden or a field. Many photographs also captured family members' spontaneous behavior. By and large, all the surviving photographs portray relatively idyllic scenes devoid of any elements that could arouse negative emotions such as fear or a sense of threat.

The surviving photographs not only enable the family's way of life to be seen in close focus, but also present the Ulmas as ordinary amiable people whose daily life is almost within touching distance. It can be seen from a unique photograph taken of the Ulma couple in 1935, probably just after their wedding, that they were two people in love. In turn, the photographs that Ulma took of his children show the pleasant, healthy, well-groomed offspring of loving, caring parents enjoying life as much as them.

The photographs are a kind of visual chronicle of the life of a family that tell of the world in which the Ulmas lived: "in the photographs he took of his wife Wiktoria and their children, one emotion can almost be felt - love" ${ }^{\text {"506. }}$. Even so,

505 Szpytma, Sprawiedliwi i ich świat.

506 “Osiemset zdjeć Józefa Ulmy”, Tygodnik Powszechny, 28 March 2016. Retrieved from: https://www.tygodnikpowszechny.pl/osiemset-zdjec-jozefa-ulmy-33004 (last accessed 9 July 2018). 
the image that became a visual icon of the family is a collage created from different photographs that is supposed to present how the family could have looked just before their tragic deaths. It is this image that can be found on the cover of the book Rodzina Ulma (The Ulma Family) ${ }^{507}$. It presents the married couple with their six children portrayed in various day-to-day life situations. The oldest girl is feeding her younger siblings, one of the children is holding a cup and the others are playing, ${ }^{508}$ and the pregnant Wiktoria is standing with the latest child to be born on her arm.

It may therefore be said that the photographs have become the basis for familiarizing the wider public with the figures of the blesseds-to-be and museum patrons as well as an element in the creation of images of them, both religious and secular. Without a doubt, they have also had a significant impact on the construction of images of their deaths. The idyllic family image portrayed in the photographs contrasts with the knowledge of the brutal deaths they suffered. The photographs enable the contrast to be sensed between life and death that has made the Ulma's story appeal so much to those who encounter it.

"Two photographs from this album may be regarded as a symbolic epilogue to this - photographic - narrative" 509 . One shows four men chopping firewood on the Ulmas' farm. These are the Goldmans: the Jews who died along with the Ulmas.

Another photograph, probably taken as late as 1942, shows two women with a child. Both of them are sitting on a blanket on some grass. They are wearing Star of David armbands. Although the identity of both these women and the child has not been confirmed, it is supposed that they are Markowa residents shot after one of the manhunts organized by the German military police. In all likelihood, they are the women hiding in a dugout in the forest who the Ulmas were helping. Such an interpretation of this photograph has to all intents and purposes become obligatory in the public discourse despite the doubts it raises. In fact, there is no evidence able to confirm the history of this photograph ${ }^{510}$.

According to accounts currently circulating about this photograph, it was found by people who, on entering the Ulmas' home after their execution, found it on the floor by the corpses of the murder victims. Since it contains traces of

507 Szarek and Szpytma, Rodzina Ulmów.

508 The photograph was taken in 1942 (Szarek, Szpytma 2014: 53).

509 “Osiemset zdjeć Józefa Ulmy”, Tygodnik Powszechny, 28 March 2016. Retrieved from: https://www.tygodnikpowszechny.pl/osiemset-zdjec-jozefa-ulmy-33004 (last accessed 9 July 2018).

510 Szpytma, Sprawiedliwi i ich świat. 
the Ulmas' and their Jewish guests' congealed blood, the photograph has become proof of the price the Ulmas paid for offering the help they provided and even a relic of the Ulmas, servants of God.

\section{Not only the Ulmas - On the Polish Righteous}

When the Jedwabne debate broke out in 2001, Shevah Weiss ${ }^{511}$ stressed that Poland must work through the consequences of what had happened in the barn in Jedwabne. However, he added that he himself remembered other barns in which Poles were hiding Jews. Subsequently, he repeated on many occasions that "There were two barns: in one they were murdering, in the other I was rescued" ${ }^{12}$. This reflection of an Israeli politician rescued from the Holocaust thanks to the help provided by Poles led Irena Steinfeldt, head of the Righteous Among the Nations Department at the Yad Vashem Institute, to the conclusion that PolishJewish history "lies somewhere between Markowa and Jedwabne" ${ }^{13}$. Steifeldt's statement clearly shows that these two places are symbols of the attitudes found at opposite poles of the spectrum. However, the Ulmas are not the only Polish Righteous. According to data released by the Yad Vashem Institute, as of 1 January 2018, the Polish Righteous numbered 6,863 ${ }^{514}$.

When reviewing Polish publications discussing the Polish Righteous that have been published over the last few years, it is difficult not to observe that the Ulmas

511 Shevah Weiss, an Israeli politician who served as Israeli ambassador to Poland from 2001 to 2003; he was rescued from the Holocaust thanks to the help he received from a Ukrainian woman and some Poles. For the role Polish neighors played in hiding Jews and the phenomenon of hideouts being employed by Jews persecuted during the Second World War, see Marta Cobel-Tokarska, Desert Island, Burrow, Grave: Wartime Hiding Places of Jews in Occupied Poland. Peter Lang: Berlin, Bern, Bruxelles, New York, Oxford, Warsaw, Vienna, 2018

512 "Szewach Weiss: Były dwie stodoły: w jednej mordowano, w drugiej mnie uratowano", an interview with Shevah Weiss. Retrieved from http://wiadomosci.dziennik.pl/ opinie/artykuly/569787,szewach-weiss-rozmowa-ustawa-o-ipn-weszla-w-zycie.html (last accessed 9 July 2018).

513 From an interview Karolina Przewrocka-Aderet conducted with Irena Steinfeldt: "Wciąż dostajemy wiele świadectw", Tygodnik Powszechny, 28 March 2016. Retrieved from https://www.tygodnikpowszechny.pl/wciaz-dostajemy-wiele-swiadectw-32997. (last accessed 9 July 2018).

514 "Names and Numbers of Righteous Among the Nations - per Country and Ethnic Origin, as of January 1, 2018". Retrieved from: http://www.yadvashem.org/righteous/ statistics.html (last accessed 9 July 2018). 
have become a recognizable symbol of Polish help provided to Jews and a key example used in the top-down management of Polish historical policy. However, it is worth noting that the decision to choose this particular family was the outcome of a chain of events that happened at the beginning of the twenty-first century. As we wrote earlier, the Ulmas did not function within public memory until 2003. By and large, before the museum in Markowa opened, attention had been drawn to other symbols of Polish memory of assisting Jews. These included the figure of Irena Sendler or the Żegota organization established in 1942 as part of the Polish Underground State, which was responsible for the rescuing of Jews. From a diachronic perspective, the success of memory of the Ulmas can be interpreted as an outcome of the evolution of discourse relating to the Righteous. It is therefore worth reflecting on how this state of affairs came about.

Regardless of whether we turn to the liberal-leftist or conservative literature on the Righteous discourse, researchers situated within these two perspectives single out similar moments in its development. However, they assign different meanings to them. An article written by Dariusz Libionka, a researcher from the Center for Holocaust Research, ${ }^{515}$ is symptomatic of one side of the debate and a book written by Jan Żaryn, a right-wing historian from the IPN, represents the other ${ }^{516}$. Both authors wrote about the Righteous historiography from 1945 to the first decade of the twenty-first century, yet they define the key nuances and watershed moments differently. Dariusz Libionka draws attention to 1963 as the turning point in the process of shaping memory of the Righteous. This was the twentieth anniversary of the outbreak of the uprising in the Warsaw ghetto. It was during this period, as Libionka writes, that official propaganda began to highlight the massive scale of the assistance provided to Jews. At the same time, it began to mention not only the merits of the communists, but also those of the Home Army or clergy, which led to the official narrative gaining the support of the Tygodnik Powszechny ${ }^{517}$ milieu and Gierdoyc's Paris-based

515 Dariusz Libionka, "Polskie studia i piśmiennictwo na temat zorganizowanej i indywidualnej pomocy Żydom (1945-2008)”, in: Zagłada Żydów. Studia i Materiały, Warsaw: Centrum Badań nad Zagładą Żydów, no. 4; 2008, pp. 17-80.

516 Jan Żaryn, "Polacy ratujący Żydów w świetle nowych źródeł”, in: Jan Żaryn, Tomasz Sudoł (eds.), Polacy ratujący Żydów. Historie niezwykłe. Warsaw: Wydawnictwo Neriton, 2014: 11-94.

517 Tygodnik Powszechny is a Catholic weekly magazine published since 1945 that discusses cultural and social topics. It tries to combine liberal values and the tenets of faith. During the Polish People's Republic, it was an important organ of the opposition, where it was possible to an extent to voice opinions that were critical of the authorities. It currently focuses on criticizing the inner workings of the church and promotes 
journal Kultura ${ }^{518}$. However, Jan Żaryn's review of the literature singles out the point when Tygodnik Powszechny became involved as being important for the development of the Righteous discourse. Żaryn mentions a survey on the Righteous Tygodnik Powszechny created in 1963, which resulted in the publication of a work of historiography titled Ten jest $z$ ojczyzny mojej. Polacy $z$ pomoca Żydom 1939-1945 [This One is from my homeland. Poles Who Assisted Jews 1939-1945 ${ }^{519}$. For Żaryn, this is a very important moment even though, as he himself writes, the survey was directed at the Polish Catholic intelligentsia, so "the accounts that flooded in at the time could not have been representative of the whole community" 520 .

Another important book from this period about Poles rescuing Jews was written by a Holocaust survivor, Szymon Datner, who worked after the war at the Jewish Historical Institute in Warsaw. In 1968, Datner published Las sprawiedliwych. Karta $z$ dziejów ratownictwa Żydów w okupowanej Polsce (The Forest of the Righteous. A Page from the History of the Rescuing of Jews in Occupied Poland $)^{521}$, in which he described Poles' motives for hiding Jews and the methods they used to do this. On the basis of a collection of documents and testimonies, he presented the first register listing the names of those who had lost their lives for rescuing Jews. The Ulmas do not appear on this list. The book was written during the anti-Semitic campaign of 1968. Since Datner was a Jew who also happened to work for the Investigation of Nazi Crimes in Poland, the authorities

open Catholicism. For the role played by Tygodnik Powszechny under communism, see Norbert Zmijewski, "Vicissitudes of Political Realism in Poland: Tygodnik Powszechny and Znak", Soviet Studies. 1991, 43(1):83-106; for the contemporary role played by Tygodnik Powszechny and Catholic intellectuals, see: Obirek, Stanislaw, "Intellectuals and Catholicism in Today's Poland”, Dialogue \& Universalism, 2003, 13 (5):77-86.

518 The Kultura monthly journal was published by Jerzy Władysław Giedroyc, a politician and publicist before the war and émigré publisher from 1947 to 2000, initially based in Rome and later in Paris, where he published through the Instytut Literacki publishing house. For Giedoyc and Kultura, see Jan Zieliński, “ 5 minutes, 94 years and much longer' (Jerzy Giedroyc, 1906-2000)", Studies in East European Thought 52: 327-331, 2000.

519 Władysław Bartoszewski and Zofia Lewinówna (ed.).Ten jest z ojczyzny mojej: Polacy z pomoca Żydom 1939-1945. Kraków: Znak, 1966.

520 Jan Żaryn, "Polacy ratujący Żydów w świetle nowych źródeł." In: Polacy ratujący Żydów. Historie niezwykłe, eds. Jan Żaryn and Tomasz Sudoł. Warsaw: Wydawnictwo Neriton, 2014, p. 21.

521 Szymon Datner, Las sprawiedliwych. Karta z dziejów ratownictwa Żydów w okupowanej Polsce. Warsaw: "Książka i Wiedza", 1968. 
expected him to make his voice heard during this politically sensitive period. As soon as the book was published, they used it as an important political evidence of the assistance that ethnic Poles had given to their Jewish compatriots. As the researchers point out, those who helped Jews during the war from the very beginning have been used as proof that Poles are not anti-Semites ${ }^{522}$. As Florian Peters writes, "the Polish Righteous have been exploited by self-proclaimed guardians of the Polish nation to counter any challenges to the heroic-martyrological selfperception of Poles" 523 .

The events of 1968 influenced the manner in which memory of the Righteous functioned within the PRL. The first film directed by Janusz Kidawa and Ryszard Gontarz, The Righteous, dates from this period. According to Elżbieta Janicka, it was "from this production that the contemporary works such as the Sprawiedliwi [The Righteous] television serial (...) Czas honoru [Days of Honor], and others, draw their inspiration" ${ }^{524}$. Since 1968, an increasing number of publications describing the Righteous' heroic deeds have appeared. A typical example of this kind of literature is a historiography of the peasant movement that emphasizes "the countryside's selfless and loyal assistance to the persecuted Jews" when describing the attitude of Poles toward the Holocaust ${ }^{525}$. At the same time, however, as Jan Grabowski maintains, "many of the Righteous preferred to hide the distinctions they had been awarded by Yad Vashem for fear of [having to face] their neighbors' irony, anger or even revenge" 526 .

522 Tomasz Żukowski, “Sprawiedliwi - sposób dyskryminacji Żydów.” Przekrój. 8 Oct. 2008, pp 20-22; Zofia Wóycicka, "Global Patterns, Local Interpretations."

523 Florian Peters, "Towards a Balanced Tribute to the Polish Righteous? The Ulma Family Museum of Poles Saving Jews in Markowa”. In: Cultures of History Forum (8 December 2016), Retrieved from http://www.culture-of-history.uni-jena.de// exhibitions/poland/towards-a-balanced-tribute-to-the-polish-righteous-the-ulmafamily-museum-of-poles-saving-jews-in-markowa/ (last accessed 9 July 2018).

524 “Elżbieta Janicka: Zderzenie cywilizacji”. Michał Siermińśki talks to Elżbieta Janicka about memorials to the Righteous, lewica.pl, 29 August 2014. Retrieved from http:// lewica.pl/?id=29760\&tytul=El\%BFbieta-Janicka:-Zderzenie-cywilizacji\%20\# (last accessed 10 July 2018).

525 Krzysztof Persak, “Wstęp.” In: Zarys Krajobrazu. Wieś polska wobec Zagłady Żydów 1942-1945, eds. Engelking, Barbara and Jan Grabowski. Warsaw: Stowarzyszenie Centrum Badań nad Zagładą Żydów, 2011, p. 11.

526 Jan Grabowski, “W sprawie Zagłady Polska gola!”, Gazeta Wyborcza, 25 April 2014. Retrieved from http://wyborcza.pl/magazyn/1,124059,15859357,W_sprawie_ Zaglady_Polska_gola_.html (last accessed 10 July 2018). 
After the political breakthrough of 1989, other hotly debated topics and missing pieces of Polish history considered to be more important for Polish national identity surfaced, such as the Soviet crimes, Warsaw uprising, and dark episodes in twentieth-century relations between Poland and Ukraine. The books about the Righteous published during this period served as a kind of tribute to them rather than acting as an important voice in the ongoing discussion on Polish attitudes during the Holocaust ${ }^{527}$.

The situation remained unchanged until the beginning of the twenty-first century. On the one hand, the Jedwabne debate activated right-wing circles that evoked the Righteous as a defensive argument and a synecdoche for the Polish attitude to Jews during the war. On the other hand, the famous words uttered by an Israeli politician who survived the Holocaust about there being two kinds of barn in occupied Poland highlighted the fact that wartime relations between Poles and Jews were much more complex and should not be perceived exclusively through the prism of what had happened in Jedwabne.

These words fell on fertile ground, especially as the sixtieth anniversary of the launch of Operation Reinhardt, which led to the extermination of the Jews in the General Government, fell in 2002. The liquidation of the ghettos meant that Jews became dependent for their survival on help from their Polish neighbors. The commemoration of this round anniversary led to the Righteous becoming a very topical subject. In Lublin, an international conference was held under the honorary patronship of the President of the Federal Republic of Germany, Johannes Rau and the President of the Republic of Poland, Aleksander Kwaśniewski, during which the subjects under discussion included the complexity of Polish-Jewish wartime relations ${ }^{528}$. The same year saw the release of the first films devoted to the Righteous, a documentary film directed by Willy Lindwer titled Messengers without an Audience ${ }^{529}$ and another documentary,

527 Two examples of this are Michał Grynberg's book, Ksiega sprawiedliwych, Warsaw: Wydaw. Naukowe PWN, 1993 and the translation of Arieh L. Bauminger's book, The Righteous Among the Nations, Warsaw: Wydawnictwo Naukowe PWN, 1994.

528 The "Aktion Reinhardt" - Zagłada Żydów w Generalnym Gubernatorstwie International Academic Conference Lublin, 7-9 November 2002, The Institute of National Remembrance. Retrieved from: https://ipn.gov.pl/pl/nauka/konferencjenaukowe/26793,Miedzynarodowa-konferencja-naukowa-Aktion-Reinhardt-ZagladaZydow-w-Generalnym-G.html (last accessed 10 July 2018).

529 The film Messengers without an Audience tells of the mission of Jan Karski and other Poles who attempted to draw the attention of the West to the Holocaust taking place in occupied Poland. 
Sendler's List, which was directed by Michał Dudziewicz. In 2004, the first film about the Ulmas, which was titled The Price of Life, was commissioned from the director Andrzej Baczyński by Polish Television Kraków. A number of feature films telling the Ulma's story were also created, such as Ulmowie. Swiadectwo sprawiedliwych (The Ulmas. Testimony to the Righteous), which was directed in 2004 by Dariusz Walusiak and updated in 2014.

In 2006, on the day before the sixty-second anniversary of the crime perpetrated against the Ulma family, when the combined primary and middle school in Markowa was being renamed the Ulma Family Servants of God School, the Minister of Culture Kazimierz Ujazdowski and chairman of the Institute of National Remembrance Janusz Kurtyka signed a joint declaration titled "Witnesses of History", in which they acknowledged the urgency of "initiating programs benefiting the preservation and dissemination of the accounts of witnesses to Polish twentieth-century history". Although the declaration speaks of the need to commemorate all witnesses to events of the twentieth century, it contains wording making it clear that "Commemoration not only requires the accounts of witnesses of watershed events familiar from the pages of history textbooks, but also the fates of such people as the inhabitants of Markowa" ${ }^{330}$. In the same year, the Institute of National Remembrance launched the "Index of Poles murdered and repressed by Nazis for assisting Jews" program, which aimed to recognize the scale of Nazi repressions against Poles who had assisted Jews during the occupation, establish their names, and describe their histories ${ }^{531}$.

The following year, President Lech Kaczyński began to decorate the Righteous with the Commander's Cross of the Order of Polonia Restituta, ${ }^{532}$ and the Museum of the History of Polish Jews began rolling out the Polish Righteous - Recalling Forgotten History project. This aims to popularize knowledge about the Righteous. In the same year, the Senate of the Republic of Poland adopted a resolution on honoring the exploits of Irena Sendler and the Żegota Council to Aid Jews during the Second World War.

During this period, an increasing number of publications about Jews being rescued during the war began to appear ${ }^{533}$. In the fall of 2008, the Gazeta Wyborcza

530 Szarek and Szpytma, Rodzina Ulmów, pp. 82-83.

531 Żaryn, "Polacy ratujący Żydów w świetle nowych źródeł”, see footnote 2, p. 12.

532 Information sourced from the website of the Polish Society of the Righteous among Nations. Retrieved from: http://www.sprawiedliwi.org/index.php/o-nas/ (last accessed 10 July 2018).

533 These include: Jacek Leociak, Ratowanie. Opowieści Polaków i Żydów, Wydawnictwo Literackie, Kraków, 2010; the Zagłada Żydów. Studia i Materiały journal, Vol. 4, 2008, 
newspaper published a series of articles by Teresa Torańska titled Sasiędzi ponad strachem (Neighbors Above Fear). As she herself explained, she was motivated to write them because "Over the last few years, much has been written about Jewish fear and Polish neighbors. It is time to also remember the Polish heroes who overcame fear, and frequently the opposition of their neighbors, to rescue Jews. (...) Let's rescue memory of them [the Polish Righteous]"534.

Sites of memory devoted to the Righteous, increasingly common in Poland, are supposed to serve as a reminder of these "Polish heroes", yet these sites provoke a great deal of controversy. As Barbara Engelking, head of the Polish Center for Holocaust Research, has written about the commemoration of Jews in Warsaw's Muranów distict, "The Tree of Common Polish-Jewish Memory, a stone commemorating Żegota, Sendler Avenue. And also the Willy Brandt Memorial erected at the back of the current museum in 2000, which presents the German Chancellor kneeling before the Monument to the Ghetto Heroes in December 1970. In the 'quiet zone', it is getting crowded and noisy" 535 . Elżbieta Janicka, the author of the book Festung Warschau, ${ }^{536}$ in which she accuses Polish memory of the martyrdom of the Polish nation of appropriating sites belonging to Jewish memory, makes the following comment about the concurrence of two memories in one place: "These monuments and counter-monuments - erected on an industrial scale according to an unremittingly predictable formula - are nothing more than a running round in circles that is spinning the community into a state of bewilderment. The situation has reached such a point that a state of symbolic natural disaster is being declared across the entire country. Some anti-monument barriers would be useful, something like floodbanks, because

which is almost totally devoted to assistance provided to Jews; publications released by the Institute of National Remembrance between 2006 and 2010, e.g., Kazimierz Iranek-Osmecki, Kto ratuje jedno życie... Polacy i Żydzi 1939-1945, Warsaw, Instytut Pamięci Narodowej, 2009; “Kto w takich czasach Żydów przechowuje?...” Polacy niosący pomoc ludności żydowskiej w okresie okupacji niemieckiej, ed. Aleksandra Namysło, Warsaw, Instytut Pamięci Narodowej, 2009.

534 “Sąsiedzi ponad strachem” - cykl artykułów Teresy Trojańskiej”, The Museum of the History of Polish Jews, 13 November 2008. Retrieved from: https://sprawiedliwi.org. pl/pl/aktualnosci/sasiedzi-ponad-strachem-cykl-artykulow-teresy-toranskiej (last accessed 10 July 2018).

535 Quoted after Jacek Leociak, "Warszawa upamiętnia Sprawiedliwych.” Nigdy Więcej, Vol. 22, 2016.

536 Elżbieta Janicka, Festung Warschau. Warsaw: Wydawnictwo Krytyki Politycznej, 2011. 
we are drowning in a deluge of commemorations. The crisis team won't be able to help out this time. We need to wake ourselves up and confront the reality"537.

It was the plan to erect a memorial to the Polish Righteous Among Nations in close proximity to the POLIN Museum of the History of Polish Jews that provoked heated debate on the meaning of Polish-Jewish memory ${ }^{538}$. The cause of this conflict could be summarized using two quotations at opposite poles of the debate. On the one hand, Barbara Engelking, a researcher from the Center for Holocaust Research, argued as follows in an article she wrote for Gazeta Wyborcza: "The Righteous undoubtedly deserve a monument. Their actions, which ran against the current of most Polish attitudes to the Holocaust, required genuine courage and heroism. Nevertheless, I think that such a monument should not be erected at this site, a site that tells the story of Jewish suffering rather than that of the Poles. This tiny part of Warsaw belongs to the Jews and must not be appropriated"539. On the other hand, Agnieszka Graff and Rafał Szymczak argued that:

The monument's design and the problem of its location are being interpreted according to an us-them, familiar-foreign, Poles-Jews matrix. When we employ the logic of the political conflict, it turns out that the memorial is a Polish sign in a Jewish district, a sign marking the appropriation of the sufferings of the Jewish nation, a pretext for comparing who suffered more or died in the most fearful circumstances. Or even a voice in the Jedwabne debate - memory of the Righteous is allegedly supposed to invalidate the pettiness and baseness of those Poles who were indifferent to the crime or participated in the Holocaust. Each one of these interpretations arouses our profound opposition ${ }^{540}$.

This opposition arises from the fact that, as Graff and Szymczak explained, "We have a sense of belonging to both nations to which this issue relates. Simply put, we are Polish Jews (or, as some may prefer, Poles of Jewish descent). We are - in

537 "Elżbieta Janicka: Zderzenie cywilizacji”. An interview about memorials to the Righteous given by Elżbieta Janicka to Michał Siermiński, lewica.pl, 29 August 2014. Retrieved from http://lewica.pl/?id=29760\&tytul=El\%BFbieta-Janicka:-Zderzeniecywilizacji\%20\# (last accessed 10 July 2018).

538 Maria Niziołek, "Gdzie jest miejsce dla polskich Sprawiedliwych? Strategie pamięci na warszawskim Muranowie”, Teksty Drugie, Vol. 1, 2014, p. 127.

539 Barbara Engelking, "Getto, powstanie, pomnik Sprawiedliwych. Cierpienie wymaga ciszy i przestrzeni." Gazeta Wyborcza, 4 Apr. 2013. Retrieved from http://wyborcza. pl/1,75968,13673789,Getto__powstanie__pomnik_Sprawiedliwych_Cierpienie. html (last accessed 10 July 2018).

540 Agnieszka Graff, Rafał Szymczak, "Wokół pomnika Sprawiedliwych. To są Nasi Sprawiedliwi”, Gazeta Wyborcza, 23 April 2013. Retrieved from: http://wyborcza. pl/1,75968,13787660,Wokol_pomnika_Sprawiedliwych_To_sa_Nasi_Sprawiedliwi. html (last accessed 10 July 2018). 
a deep ethnic or ontological sense - the grandchildren and great-grandchildren of the Righteous. We would not be in the world if it were not for Them. In this sense, they are OURS, they belong to us, and we to them"541.

The desire Agnieszka Graff and Rafał Szymczak expressed to construct a sense of Polish-Jewish unity cannot be reconciled with the objectives of the official discourse on the Righteous, which aims to incorporate the Righteous into the pantheon of Polish national heroes. This is perfectly exemplified by how the discussion on the Memorial to the Righteous in Warsaw concluded. The decision was taken to erect the state memorial in Grzybowski Square near the All Saints parish church, while Jewish Holocaust survivors would erect their own memorial near the Museum of the History of Polish Jews. As Maria Niziołek concludes in an article summarizing the debate on the memorial: "The Jews will construct their own monument at a site that belongs to them and the Poles will do exactly the same" (Niziołek 2014: 140). According to Niziołek, such a solution "squanders [the opportunity] (...) to design a mutually complementary PolishJewish memory" ${ }^{442}$. However, Elżbieta Janicka assesses this situation much more harshly, writing that "'as far as this narrative is concerned, a Catholic-Polish memorial' and 'Jewish memorial' are two sides of the same coin"543.

The importance of both this interpretative dispute and the creation of "new" Righteous modeled on Polish national heroes is also evidenced by the National Bank of Poland's decision to issue a series of numismatic coins portraying Poles rescuing Jews. The first such coin was issued in 2009. It depicts three women, Zofia Kossak, Sister Matylda Getter, and Irena Sendler. Three years later, in 2012, the National Bank of Poland issued the next coins in the series, this time featuring an image of three families who had rescued Jews: the Ulmas, Baraneks, and Kowalskis.

In 2009, the Kowalski family were the first to be posthumously awarded the Commander's Cross of the Order of Polonia Restituta. This honor was conferred on them by President Lech Kaczyński for their "heroic attitude and

541 Agnieszka Graff, Rafał Szymczak, "Wokół pomnika Sprawiedliwych. To są Nasi Sprawiedliwi”, Gazeta Wyborcza, 23 April 2013. Retrieved from: http://wyborcza. pl/1,75968,13787660,Wokol_pomnika_Sprawiedliwych_To_sa_Nasi_Sprawiedliwi. html (last accessed 10 July 2018).

542 Niziołek, „Gdzie jest miejsce dla polskich Sprawiedliwych?, p. 140.

543 “Elżbieta Janicka: Zderzenie cywilizacji”. An interview about memorials to the Righteous given by Elżbieta Janicka to Michał Siermiński, lewica.pl, 29 August 2014. Retrieved from http://lewica.pl/?id=29760\&tytul=El\%BFbieta-Janicka:-Zderzeniecywilizacji\%20\# (last accessed 10 July 2018). 
extraordinary courage shown when saving the lives of Jews during the Second World War, and for outstanding services rendered in the defence of human dignity and human rights" ${ }^{344}$. Subsequently, the same posthumous honor was granted to the members of the Ulma family (by President Lech Kaczyński on 25 January 2010) and Baranek family (by President Bronisław Komorowski on 15 November 2013). It is worth adding that the other two families, the Kowalskis and the Baraneks, were much better known at the time. Information about their deaths first appeared in the earlier mentioned book that Szymon Datner published in 1968. The issuance of the commemorative coins depicting the three families in 2012 was timed to mark the occasion of the ceremonial celebration of the sixty-ninth anniversary of the Baranek family's death $s^{545}$. The following year, Grzegorz Górny, a well-known Polish right-wing columnist and editor-in-chief of the Frond $a^{546}$ quarterly for over a decade, wrote a book titled Sprawiedliwi. Jak Polacy ratowali Żydów przed Zagłada ${ }^{547}$ (The Righteous. How Poles Rescued Jews from the Holocaust). Its introduction was written by the famous British historian Norman Davis. In his book, Górny provides an in-depth description of the fates of the Baraneks and Kowalskis, and a photograph of the Kowalskis was chosen for its cover. The Ulmas are only mentioned in passing.

The decision to reward and honor "ordinary people" was evidently a turning point in the shaping of memory of the Righteous. The women honored in 2009, namely Zofia Kossak, Sister Matylda Getter, and Irena Sendler, were social activists from intelligentsia circles who cooperated with the Polish Underground State and were active Żegota members. All of them survived the war. The Baraneks, Kowalskis, and Ulmas were peasant families who were cruelly murdered with

544 "Postanowienie Prezydenta RP o pośmiertnym nadaniu orderów Krzyża Odrodzenia Polski”, Monitor Polski No. 28, item 319. Retrieved from: http://prawo.sejm.gov. pl/isap.nsf/download.xsp/WMP20100280319/O/M20100319.pdf (last accessed 15 April 2018).

545 "Obchody 69. rocznicy zbrodni na rodzinie Baranków i ukrywanych przez nich Żydach oraz promocja monet "Polacy ratujący Żydów - rodzina Ulmów, Baranków, Kowalskich” - Miechów, 15 March 2012”, Instytut Pamięci Narodowej. Retrieved from https://ipn.gov.pl/pl/aktualnosci/8359,Obchody-69-rocznicy-zbrodni-na-rodzinieBarankow-i-ukrywanych-przez-nich-Zydach-.html (last acessed 10 July 2018).

546 Fronda is a sociopolitical quarterly with a conservative profile first published in 1994 by Grzegorz Górny and Rafał Smoczyński.

547 Grzegorz Górny and Norman Davis, Sprawiedliwi. Jak Polacy ratowali Żydów przed Zagłada. Warsaw: Rosikon Press, 2013. 
their children, and in the Kowalskis' case with their neighbors, for assisting Jews. The decision to honor such families resulted in "ordinary" Righteous from the peasantry joining the ranks of official examples of the "terrible price Poles often paid for their courage and heroism when providing assistance to the persecuted Jews" 548 .

From a domestic perspective, this turn within Poland toward the positive reevaluation of previously little-known histories of peasant families who had rescued Jews during the war may be interpreted as an response to the Jedwabne case and the accusation that the peasant population (or even the Polish nation as a whole) had participated in the Holocaust. From a global perspective, it may be interpreted as a side effect of a global turn toward "ordinary people" that has been observable for years within the sphere of social life ${ }^{549}$. Another cause is the appearance of victimhood nationalism ${ }^{550}$. What is at stake in this new type of nationalism is moral capital, ${ }^{551}$ which provides a state of victimhood of a sacrifice type. The Righteous are a paradigmatic example of moral victimhood, and this is best exemplified by the Ulmas. They are not only globally recognized thanks to Yad Vashem awarding them their medal, but the fact that they have been beatified by the Catholic Church further enhances the moral capital they have produced. This explains why, of the three Righteous families, it is the Ulmas that have turned out to be the most popular and significant example. However, it should be remembered that an important role was played in the emergence of the Ulmas' story by the fact that the family left behind material remembrances, especially the numerous photographs. However, the active engagement of memory actors, in particular the Ulmas' living relatives and local community, in developing this story's moral dimension, was no less important.

548 "NBP upamiętni Polaków ratujących Żydów na nowych monetach okolicznościowych", The National Bank of Poland, 13 March 2012. Retrieved from http://www.nbp.pl/ home.aspx?f=/aktualnosci/wiadomosci_2012/monety_rodziny.html (last accessed 10 July 2018).

549 Piotr T. Kwiatkowski, Pamięć zbiorowa społeczeństwa polskiego w okresie transformacji, Warsaw 2008; Marta Kurkowska-Budzan, Historia zwykłych ludzi. Współczesna angielska historiografia dziejów społecznych, Towarzystwo Wydawnicze "Historia Iagellonica”, Kraków 2003, pp. 176-187.

550 Lim, "Victimhood Nationalism".

551 Łuczewski, Kapitał moralny. 


\section{The Religious and National Political Dimensions of Memory of the Ulmas}

After the museum opened in Markowa, the Ulmas' story not only gained exposure in new places (for example, the Museum of the Second World War in Gdańsk, where their images and a description of their story was incorporated into its permanent exhibition), but was portrayed in new contexts. A number of ecclesiastical publishing houses have published books based on their story, ${ }^{552}$ and poetry about the Ulmas has become more popular, in particular a hagiographic poem by Maria Szulikowska titled $Z$ ziemi do nieba ${ }^{553}$. The Ulmas' story has also began to appear in fictionalized form. In 2009, Rafał Wierczyński shot a documentary film about the Ulma family titled Świat Józefa (Józef's World) and is currently creating a full-length feature film titled Spójrz mi w oczy (Look Me in the Eyes $)^{554}$.

The Ulmas' example has therefore become a premise and argument in discussions far removed from the original assumptions of the creators of the museum named after them. It has been used both in discussions on attitudes of Poles during the war and to manage historical policy and contemporary methods of exploiting and interpreting events from the past. The discussion conducted in Gazeta Wyborcza between historians from the Center for Holocaust Research and Mateusz Szpytma, by then vice-chairman of the Institute of National Remembrance, turned out to be particularly heated in this respect ${ }^{555}$. It occurred

552 Maria Szulikowska, Markowskie bociany: opowieść o bohaterskiej rodzinie Wiktorii i Józefa Ulmów. Przemyśl: Wydawnictwo Archidiecezji Przemyskiej, 2017.

553 Stanisław Gęsiorski, “Z ziemi do nieba!” Radio FAR, 24 August 2017. Retrieved from http://przemyska.pl/2017/08/24/z-ziemi-do-nieba/ (last accessed 10 July 2018).

554 Wieczyński has also created such well-known films as a biographical film about Blessed Jerzy Popiełuszko titled Popiełuszko. Wolność jest w nas (Popiełuszko. Freedom is within Us).

555 See the following articles: Adam Leszczyński, "Na likwidację Żydów pojechałem. Kowalski Jan.” Gazeta Wyborcza. 30 Juy 2016. Retrieved from: http://wyborcza. pl/magazyn/1,124059,20473795,na-likwidacje-zydow-pojechalem-kowalski-jan. html (last accessed 10 July 2018); Jan Grabowski and Dariusz Libionka. "Markowa. Żydowska śmierć, polska wina, wspólny strach.” Gazeta Wyborcza. 9 Dec. 2016. Retrieved from: http://wyborcza.pl/magazyn/7,124059,21097043,markowazydowska-smierc-polska-wina-wspolny-strach.html (last accessed 10 July 2018); “Demaskujemy kłamstwo w 'Gazecie Wyborczej' na temat Polaków rzekomo mordujących Żydów.” the wPolityce.pl website. 20 Dec. 2016. Retrieved from: https:// wpolityce.pl/historia/320314-demaskujemy-klamstwo-w-gazecie-wyborczejna-temat-polakow-rzekomo-mordujacych-zydow (last accessed 10 July 2018); 
during a time when studies were being published on the role played by Polish firefighters in the massacring of Jews in the Subcarpathian region, in such places as Markowa and its environs ${ }^{556}$. This led to Markowa's example becoming a starting point not only for the revealing of a heroic vision of the past, but also for discussions about Polish society's perceived reluctance to remember and commemorate examples of the expulsion of people in hiding, Jew "hunts", Poles collaborating with the German authorities and, ultimately, massacres of Jews perpetrated by Poles and postwar anti-Semitism and anti-Jewish violence. The exhibition at the museum in Markowa also formed the basis for a discussion in Poland's daily newspaper about the actual transmission of knowledge about the Holocaust, the manner in which past events were being presented and, ultimately, the manner in which witness statements should be treated when being compared with sources that form the basis of the classical historical method, such as court documents or statistics. Over the years and publications that followed, such concerns returned in various contexts. However, two opposing positions were particularly evident within this discourse. On the one hand, the Ulma family, Poles who had rescued Jews or the museum itself were discussed within the context of criticism of Polish historical policy ${ }^{557}$. On the other hand, successive publications appeared that acted as apologies which praised the family and focused on the positive aspects of Poles' attitudes toward the Jews during the Second World War ${ }^{558}$.

Memory of the Ulmas shows how many factors influence narratives of past events and how this influence varies in strength and affects different fields. These factors may be the conflicting needs and aspirations of various groups coming from various levels of a social aggregate (for example, a local aspiration to commemorate a family and a top-down need to use local history to serve

Mateusz Szpytma, "Czyje te bezdroża? Polemika z tekstem 'Markowa. Żydowska śmierć, polska wina, wspólny strach””. Gazeta Wyborcza. 6 Jan. 2017. Retrieved from: http://wyborcza.pl/magazyn/7,124059,21211362,czyje-te-bezdroza-polemikaz-tekstem-markowa-zydowska.html (last accessed 10 July 2018); Jan Grabowski and Dariusz Libionka, "Polacy pomagali Żydom i ich zabijali. Dyskusja o Muzeum w Markowej”. Gazeta Wyborcza. 6 Jan. 2017. Retrieved from: http://wyborcza.pl/ magazyn/7,124059,21211571,polacy-pomagali-zydom-i-ich-zabijali-dyskusja-omuzeum-w-markowej.html (last accessed 10 July 2018).

556 Grabowski and Dariusz Libionka, "Bezdroża polityki historycznej”.

557 Grabowski and Dariusz Libionka, "Bezdroża polityki historycznej”; Forecki, "Muzeum Zgody w Markowej."

558 Szulikowska, Markowskie bociany. 
current policy). On the other hand, these factors could also be the differing perspectives of people crucial to a given narrative (exemplified by the discussion between Jan Grabowski and Mateusz Szpytma). Ultimately, different goals and forms of remembering and commemorating influence the manner in which the past is narrated (a hagiographic narrative of religious commemorations is quite different from the secular historiographical narrative of memory specialists expressed through a museum exhibition). The only questions that remain are which of these factors will come to dominate which area and which actors will be most influential and for how long.

The situation is better contextualized by taking into account another memory project relating to the Righteous being developed by Father Tadeusz Rydzyk. Despite being well-known for the anti-Semitic views he presents on air at Radio Maryja, he has been developing his own project dedicated to the Polish Righteous. In 2002, the Radio Maryja community published the testimonies of the Righteous they had collected as a book titled Godni synowie naszej Ojczyzny. Świadectwa nadestane na apel Radia Maryja ${ }^{559}$ (Worthy Sons of Our Homeland. Testimonies Sent at the Behest of Radio Maryja). The intellectual and academic value of this book was appreciated by right-wing scholars ${ }^{560}$. As soon as Law and Justice became the party of government, Father Rydzyk's projects began to receive state funding. In 2016, a Chapel of Remembrance dedicated to the Polish Righteous was opened in the catacombs of the Our Lady, Star of the New Evangelization and St John Paul II Sanctuary in Torun ${ }^{561}$. The architecture and symbolism of this church fully express the essence of Father Rydzyk's vision of the Catholic Church's role and importance for the history of the Polish nation. The dedication of one of its chapels to the story of the Righteous, known there as "twentieth-century Polish martyrs", shows how important this history is to the vision of Polish history created by the Radio Maryja community. The chapel's symbolism is in itself symptomatic:

The central position is occupied by the figure of Our Lady Immaculate symbolically crushing the head of a serpent with her foot. On the wall behind her are the reliquaries of various Polish martyrs (including Maximilian Kolbe, Blessed Father Jerzy Popiełuszko, Blessed Father Wincenty Frelichowski and the Blessed Eleven Sisters of the Holy Family

559 Alicja Augustyniak (wybór tekstów), Godni synowie naszej Ojczyzny: świadectwa nadestane na apel Radia Maryja. Warsaw: Wydawnictwo Sióstr Loretanek, 2002.

560 Żaryn, "Polacy ratujący Żydów w świetle nowych źródeł”, p. 22.

561 Sourced from the website of the Chapel of Memory. Retrieved from http://kaplicapamieci.pl/ (last accessed 10 July 2018). 
of Nazareth ${ }^{562}$ ) and further back, a wall of polished black granite inscribed with the names of Poles murdered by the Germans for rescuing Jews during the Second World War. The heroism of these Poles is recalled using a quote from the Holy Scriptures: 'There is no greater love than to lay down one's life for one's friends. The chapel's window frames are filled with four large stained-glass windows - each one containing a scene from the pontificate of John Paul II $^{563}$.

By the entrance to the chapel, there are multimedia boxes containing information about the importance of the Righteous' stories to twentieth-century Polish history.

It was in this chapel in November 2017 that the Remembrance and Hope International Conference devoted to the attitudes of Poles who had saved Jews during the Second World War was held ${ }^{564}$. It was attended by senior representatives from the state authorities headed by incumbent prime minister Beata Szydło and future prime minister Mateusz Morawiecki. Beata Szydło spoke the following words in the speech she gave: "We are friends, we are brothers. Today we must, as one voice, speak aloud the truth about those times. We must talk of heroic Jews and heroic Poles. It is we Poles and Jews - Poland and Israel - who have most to say on this issue. For this is our common cause, common hope, common truth, common love" ${ }^{565}$. The President, Andrzej Duda, underlined the

562 All these people were active in the life of the Catholic Church and engaged in proindependence activities. They were murdered, thereby becoming important symbols of the suffering that both the Catholic Church and Poles as a nation endured under German occupation and during communist times. Saint Maximilian Kolbe was an Auschwitz prisoner who decided to surrender his own life in exchange for the life of a fellow prisoner. Blessed Father Stefan Frelichowski was a committed activist for the Polish scouting movement. In 1945, he died of typhus at the Dachau Concentration Camp. He was beatified in 1999 and is currently the Polish scouts' patron. The sisters from the convent of the Congregation of the Sisters of the Holy Family of Nazareth in Nowogródek (now Navahrudak, in Belarus) volunteered to die in place of a Polish family and their superior, Father Aleksander Zienkiewicz. The people were to be shot in retaliation for the operations of local partisan units. In 2000, they were beatified by the Catholic Church.

563 "Kaplica Pamięci", Toruński Serwis Turytyczny, 30 April 2017. Retrieved from http:// www.turystyka.torun.pl/art/1711/kaplica-pamieci.html (last accessed 10 July 2018).

564 "Prezydent o Polakach ratujących Żydów: zasłużyli na miano największych bohaterów", TVP Info, 26 November 2017. Retrieved from https://www.tvp.info/34965531/ prezydent-o-polakach-ratujacych-zydow-zasluzyli-na-miano-najwiekszychbohaterow (last accessed 10 July 2018).

565 "W Toruniu odbyła się konferencja 'Pamięć i Nadzieja”, Radio Maryja, 26 November 2017. Retrieved from http://www.radiomaryja.pl/informacje/toruniuodbyla-sie-konferencja-pamiec-nadzieja// (last accessed 10 July 2018). 
following in a letter that he addressed to the conference attendees: "Torun's sanctuary (...) is becoming one of the most important sites of memory commemorating people who, like the soldiers of the AK and civilian activists of the Polish Underground State, deserve to be called our most important national heroes" ${ }^{\prime 566}$.

The history of the Righteous as national heroes is supposed to become one of the most important themes presented in the new multimedia Memory and Identity Museum whose establishment is being funded by the Ministry of Culture and National Heritage. The museum will present the history of Poland in a manner that stresses the importance of religion and the Catholic Church to the nation's past. It has been emphasized that "in the museum witness accounts from those times will be exhibited that have been collected over many years by the Torun Center (over 40,000 records collected since 1995)"'567. As the Deputy Prime Minister and Minister of Culture and National Heritage Piotr Gliński emphasized while signing the agreement to construct the new museum, "The Memory and Identity Museum fills a significant gap in the package offered by our museums, which continues to insufficiently cover both the axiology of John Paul II and the issue of Polish-Jewish relations during the Second World War"568. It may be supposed that the story of the Ulmas, who have been given so much exposure in Toruńs Chapel of Remembrance, will also be on display at the new Memory and Identity Museum. It is beyond question, therefore, that the local, national, and religious dimensions of memory of the Ulmas will continue to evolve.

566 "Prezydent o Polakach ratujących Żydów: zasłużyli na miano największych bohaterów", TVP Info, 26 November 2017. Retrieved from https://www.tvp.info/34965531/ prezydent-o-polakach-ratujacych-zydow-zasluzyli-na-miano-najwiekszychbohaterow (last accessed 10 July 2018).

567 “W Toruniu powstanie Muzeum 'Pamięć i Tożsamość' im. św. Jana Pawła II. Wicepremier Gliński: 'Wypełni istotną lukę w naszej ofercie muzealnej”', wPolityce. pl, 21 June 2018. Retrieved from https://wpolityce.pl/kultura/400693-powstaniemuzeum-pamiec-i-tozsamosc-im-sw-jana-pawla-ii (last accessed 10 July 2018).

568 “W Toruniu powstanie Muzeum 'Pamięć i Tożsamość' im. św. Jana Pawła II. Wicepremier Gliński: 'Wypełni istotną lukę w naszej ofercie muzealnej”', wPolityce. pl, 21 June 2018. Retrieved from https://wpolityce.pl/kultura/400693-powstaniemuzeum-pamiec-i-tozsamosc-im-sw-jana-pawla-ii (last accessed 10 July 2018). 


\section{Conclusion}

By the side of five roads leading to Wojsławice, a small village in southeastern Poland, there are five shrines. When local residents are asked about these shrines' historical origins, they tell a tragic story that took place in their village in the eighteenth century. At the time, Wojsławice was a small town with a large Jewish community. At the invitation of a local noblewoman, Marianna Daniłowicz Potocka, a Jewish sect appeared in the town that conspired to take over the businesses of local Jewish merchants, who were accused of committing ritual murder. This led to a rabbi being sentenced to death by quartering and a pogrom being perpetrated against local Jews. Those who survived were banished from the town. Before he met his death, the rabbi cast a curse on the local townspeople, and it was their wish to protect themselves from that curse that led to them building the five roadside shrines. Three of them were dedicated, in turn, to the following saints who were supposed to protect them from potential consequences (given in brackets) of the curse's realization: St John Nepomucen (floods), St Florian (fires), and St Thecla (bubonic plague). The fourth one was dedicated to St Barbara, who was the patron saint of the Good Death and the fifth to St Michael the Archangel, who is the defender against the forces of evil. Despite the attempts undertaken to protect itself from the curse, the town fell into decline, lost its municipal rights, and never regained the splendor it had possessed before the tragic pogrom. The story of the history of the shrines' origin was passed down from generation to generation and has been confirmed by archival documents ${ }^{569}$.

Even though the shrines in Wojsławice come from a different historical period to those analyzed in this book, the example of these memorials is still worth evoking in the conclusion of a book discussing the manner in which local communities commemorate the past. This is the case because, despite the passage of three hundred years, which included the partitioning of Poland and two world wars, the tragic story that played out in Wojsławice in 1762 is still remembered by residents of this village in the twenty-first century. It functions in the form of a legend yet possesses a clear moral message. The shrines themselves are tended to as memory markers of those events and serve as a place of prayer for

569 Jolanta Pawlak-Paluszek, "Świat świątków i wspomnień - kapliczki świadkami dziejów ziemi chełmskiej.” In: Krzyże i kapliczki przydrożne jako znaki społecznej, kulturowej i religijnej pamięci, eds. Jan Adamowski and Marta Wójcicka. Lublin: Wydawnictwo Uniwersytetu Marii Curie-Skłodowskiej, 2011. 
older villagers during religious rituals. Furthermore, they have been entered on the register of local objects of cultural heritage and are currently being promoted as a tourist attraction by the local commune. It may therefore be said that they continue to serve as functioning sites of memory despite the fact that their social function has changed through time. Nevertheless, their story has been passed on to successive generations through the centuries in a form that has remained almost unchanged. Consequently, the example of the shrines in Wojsławice shows that certain past events bearing the hallmarks of local trauma are able to live on in the memory of this community despite the extinction of communicative memory of these events and global transformations in worldview that have political, social, and cultural ramifications ${ }^{570}$. In Wojsławice the past has been preserved in the distinctive form of cultural memory that has a religious dimension yet is global in character, because it exemplifies the local reworking of a global Christian pattern of working through group feelings of guilt and fear. At the same time, this example shows that in cases when collective trauma has been experienced, memory of a tragic event can even endure within a local community for over a dozen generations.

In this book, we have reflected on how local communities remember events that were traumatic for them by conducting in-depth analyses of four examples of memory of wartime events functioning within the local communities residing in Kałków, Michniów, Jedwabne, and Markowa. We have attempted to describe what shapes this memory or influences the form it takes, how it functions, and what social function it performs. Since, at first sight, the modes of remembrance employed by the various local communities, namely shrines, crosses, and rituals of a religious nature, would appear to greatly resemble each other, we considered whether these similarities arose from certain processes relating to the functioning of memory that are shared by different local communities. However, we quickly realized that each of the processes occurring in these four local environments has a different provenance and fulfills a different role. We therefore take a dual approach in this conclusion. On the one hand, we summarize the four case studies we have presented of the functioning of memory of wartime/ traumatic events within local memory, showing what the analyzed cases have

570 After Michel Foucault, we might claim that from the eighteenth century to today a complete transformation of the episteme, the system of explaining and comprehending the world, has taken place. In spite of this, in Wojsławice, explanations of the history of the pogrom have continuously taken the form of a legend embedded in the interpretative framework of religion (see Michael Foucault, The Order of Things: An Archaeology of the Human Sciences. New York: Pantheon Books, 1970). 
in common and how they differ. On the other hand, we draw attention to those research issues that we believe are key to the understanding of how memory functions within local communities yet require further research and analysis.

In each of the places we analyzed, before either the state or Church appeared as a "memory actor", proposing its own meta-framework for the interpretation of local events, memory of the wartime events that took place in the places in question functioned in the distinctive form of local memory. In the case of Kałków and Michniów, local memory manifested itself as community prayers for the dead said on the anniversary of the tragedy at their place of burial. In Kałków's case, this place was the cemetery in Krynki and the mass graves in Żuchowiec and Gębice. In the case of Michniów, these prayers took place at the chapel specially built for the purpose near the murder victims' collective grave. In Jedwabne, local strategies appeared for coping with a collective sense of guilt driven by beliefs about divine punishment and the need to atone for such guilt. Tending to memorials commemorating murdered Jews and their official remembrance on a Catholic holiday, All Saints' Day, has become one of the forms of global atonement for collective guilt. In Markowa's case, memory of the Ulmas mainly functioned within family memory as a tribute paid to the family ancestors, and if it were not for the appearance of external actors interested in this family's history, it does not appear that their story would have lived on in local cultural memory. It may therefore be said that in the case of all four local communities, up until the point when external actors emerged, it was first and foremost religion that set the boundaries of a framework for remembering and commemorating wartime events. On the one hand, this framework was delineated by religious rituals for remembering the dead typical of Catholic rite and on the other, by popular notions of the manner in which God intervenes in the life of a community ("divine punishment") rooted in a Christian vision of the world.

At the same time, however, these examples demonstrate how important a community's determination and a group desire to preserve memory can be. After all, in both Kałków and Michniów, group prayers for the deceased began to be held. However, the inhabitants of Michniów not only constructed a collective grave but also erected a chapel where they could pray together and created local songs and a local prayer for those who died in the pacification. Consequently, memory of the pacification began to function in different, mutually complementary vernacular repositories of memory, leading to it assuming the form of cultural memory that was vernacular in character. On the one hand, it drew on a religious conceptual framework for commemoration (manifested in the chapel and prayers) and on the other, it drew on modes of remembrance typical of high culture (poetry and song). As a result, memory of the pacifications became an 
important component of local identity. A similar process did not occur in Kałków because both the pacified villages became part of a new village rather than being rebuilt. Moreover, no additional repositories of memory were created there to support the local community's memory. This memory functioned exclusively in the form of individual cases of a religious ritual being performed to remember the dead, which arose from the conviction that everyone needs to remember deceased loved ones. However, since the time horizon receded into the distant past as one generation replaced another, the new, young local inhabitants did not feel any need to continue remembering the dead. Our interviews show that they had begun to lose a sense of continuity with a generation that had vanished some time before and the story of how they had lived and died.

The situation is complicated further when local history begins to fall into the orbit of interest of external institutions, in particular the state or Church. The cases we analyzed of local history being incorporated into a national or religious discourse demonstrate what an important role in the process of making local history public knowledge is played by memory activists who insert local history into external interpretative frameworks. In the case of Kałków, it was the local parish priest Father Czesław Wala who took on this role, because he was moved so much by the history of the local pacifications that he decided to create the Catholic Sanctuary dedicated to human suffering. In the case of Jedwabne, it was Tomasz Gross who used his Neighbors book, which was based on Jedwabne's local history, to call on Polish society to reflect on the relations between ethnic Poles and their Jewish compatriots during the war. Markowa's memory activists were the relatives of the Ulmas, who initiated the process whereby the murdered family were awarded the title of Righteous Among the Nations, which in turn enabled them to launch remembrance activities taking place on a national, or even international, rather than local or regional scale. Responsibility for these activities was later assumed by Father Stanisław Leja, who, in his role as local parish priest, became an advocate for the Ulmas' canonization, and Mateusz Szpytma, a Markowa native with a university education who inspired the foundation of a museum of which he became the first director. These examples show that both local and supralocal narratives and forms of commemoration need specific individuals who will become involved in remembrance practices for specific reasons. At the same time, however, these examples show how important a role is played in the process of increasing public awareness of local history by the social and symbolic capital held by a producer of memory.

Both Father Czesław Wala and Father Stanisław Leja were unquestioned authorities for Kałków and Markowa, the local communities they served as parish priests, so they possessed the tools to mobilize the local inhabitants. On 
the other hand, as priests of the Catholic Church, they also had access to broader religious interpretations and could count on the support of their superiors, which made it possible for them to create supralocal religious projects based on the local history of the parishes they served. Likewise, Mateusz Szpytma's heightened social status and academic title had led to him becoming an unquestioned authority for Markowa's inhabitants. The situation was different in Gross's case. He was unknown in Jedwabne when he published his book, which would not have been noticed locally if it had not been for the standing he enjoyed among the leftist liberal intelligentsia of large Polish cities and international academia. It was precisely this social and symbolic capital that Gross enjoys among this social group that caused Jedwabne's history to become the focus of public debate and provoked the erection of a memorial of national importance in the town. Although the earlier criminal trials and Danuta and Aleksander Wroniszewski's article had increased public awareness of Jedwabne's history, they had not led to it being incorporated into national memory.

Therefore, rather than being a unidirectional process, the manner in which memory functions in local communities and local memory becomes a component of national memory dependent on many factors. The nature of the event that occurred itself and the manner in which that event is spoken of and commemorated are equally relevant. Both local and supralocal forms of remembrance not only arise from the competing needs and aspirations of various groups from various levels of a social aggregate (for example, a local aspiration to commemorate a family and a top-down need to use this family's history to serve existing policy), but also the varying perspectives of the people crucial to a given narrative (as exemplified by the discussion between Jan Grabowski and Mateusz Szpytma in Markowa or Jan Gross and Tomasz Strzembosz in Jedwabne) or ultimately, the varying aims and forms of remembering or commemoration that influence the manner in which the past is discussed (for example, the hagiographic narrative of religious commemorations and the historiographic secular narrative of memory specialists, which is expressed through museum exhibitions).

Our research also shows that local history functions differently depending on whether it becomes part of the ecclesiastical metanarrative or the state narrative. In all the cases we analyzed, there was a point when both the religious and secular narratives became prominent. In the case of Kałków, the religious narrative was dominated by Father Wala and his notion of building a sanctuary dedicated to human suffering and the secular narrative was dominated by the Polish People's Party (PSL) and that party's historical policy, which was centered around turning Kałków into a central site of memory dedicated to peasants. In Jedwabne's case, the secular narrative was appropriated by the President's Chancellery, which 
struggled to establish a memorial proposing a secular method of working through the past that reflected European memory of the Holocaust, while the religious narrative was steered by the local parish priest, who supported the idea of constructing a memorial rooted in religious notions to those murdered in the East and was in favor of changing Jedwabne's parish church into a place for commemorating twentieth-century martyrs from the Łomża region. In Markowa's case, the two sides are represented by the secular museum dedicated to Poles that rescued Jews and the Catholic sanctuary dedicated to the Ulma family that is being created in the local parish church. In Michniów's case, it is symptomatic that the whole community stands guard over the religious language of remembrance and accepts any new forms of commemoration as long as they possess religious elements. This explains why a new chapel will be an integral component of the secular Mausoleum and also why the chapel currently existing in the village will not be moved.

At the same time, however, the examples we have analyzed show that at the point when religious interpretative frameworks began to dominate, social discussion centered around the narrative in question tails off. This process is exemplified by the Sanctuary in Kałków, a place that provoked heated political debate during the 1980s. The communist authorities did everything in their power to prevent the building being constructed. Nowadays, the Sanctuary is beyond the horizon of interests of secular memory activists, who make no attempt to either support or oppose the interpretation of the past the Sanctuary is proposing. This place is changing into a Catholic sanctuary even though it is a historicized site of memory telling Poland's twentieth-century history. Likewise, the controversies and discussions in Markowa are focused around the secular museum, while the Ulmas' canonization process and the pilgrimage movement developing in the village function beyond the horizon of interests of secular memory actors (and even researchers of this memory). As a matter of fact, religious actors do not appear to show much interest in secular memory projects either, with the exception of the state memorial in Jedwabne, which initially provoked a lively response from the church community. However, when the Jedwabne debate subsided, opposition to the memorial also tailed off. The Catholic Church has found a way to make the monument more palatable by conferring on it the role of a site of memory marking a space for the manifestation of internal ecumenical policy.

This lack of interest shown by both secular and religious activists in pursuing mutually beneficial memory-shaping activities may give the impression that both systems function on two parallel levels that never come into contact with each other. However, this is not entirely true. As we have shown in this book, religious and secular forms of commemoration interpenetrate, inspiring, complementing, 
neutralizing, or reinforcing each other. They are permanently directly dependent on one another, as is clear from the form assumed by the memory landscape in Michniów or Markowa. Consequently, both systems of remembrance - religious and secular - need to be examined from a holistic perspective if we are to understand the manner in which memory of past events, some of which may be traumatic, functions within the memory of local communities. It is worth stressing that this turn towards a post-secular approach to the investigation of the manner in which memory of traumatic events functions in local communities is increasingly evident in the literature, ${ }^{571}$ although it requires further research and theoretical development.

Such a post-secular approach is all the more important because it is evident that the global turn towards religious interpretations of twentieth-century history is gathering momentum ${ }^{572}$. In Central and Eastern Europe this is most visible in the actions of the Catholic and Russian Orthodox Churches. Each of these churches, in its own way, perceives the twentieth century as a time when members of its own communities suffered persecution, so both Churches, each in its own fashion, have canonized many victims of wars and repressions, perceiving them as martyrs to their faith and Christian values. The Russian Catholic Church calls these twentieth-century saints New Martyrs, thereby showing how unique they are in the Church's history. The actions of these Churches are providing new frameworks for interpreting the past that enable old models to be loaded with new meanings. This memory mobilization being undertaken by Christian Churches is not without influence on the functioning of secular memory. It is also creating new opportunities for local memory actors to take action, a process that is excellently exemplified by the involvement of Markowa's inhabitants in the Ulma family's canonization process.

Our research also showed that the memory of local communities is conditioned by class. Transmission of peasant memory mainly occurs within the family or local environment. This happens because poorly educated villagers only know one method of transmitting narratives of the past - by recalling them within the company of their loved ones and then commemorating the deceased in a religious form (the grave, the cross, and Masses for the souls of the dead). Apart from a few exceptional cases, they do not have the sociocultural competencies

571 Magdalena Lubańska, "Postmemory of Killings in the Woods at Dębrzyna (194546): A Post-Secular Anthropological Perspective.” Ethnologia Polona, Vol. 38, 2018.

572 Karin Hyldal Christensen, The Making of the New Martyrs of Russia. Soviet Repression in Orthodox Memory. London \& New York: Routledge, 2018. 
to break through to the public sphere with their memories, but also do not feel much of a need to do this. As our research shows, up until the appearance of external actors who expand local communities' horizons of opportunities and show them how they can exploit their memory of a given event for their own particularist ends, memory of the war fulfills a very specific function in these places. Since it preserves social relations with the deceased and the community in question's place of residence, it is a vital element of community life.

External memory producers who increase public awareness of local history also have other sociocultural competencies. These people possess the knowledge and skills to make them "manufacturers" and "sellers" of narratives of the past. They know how to make local stories (relating to the family, specific people, and individual places) part of national culture and the historical narrative. They can also cause the local history mentioned above to assume the status of a national (and sometimes even universal) symbol, something which is beyond the capabilities of memories produced by the peasant class. Moreover, the conviction reigns among members of the intelligentsia that their experiences and reflections should be made available to others, while the opinion is commonly encountered among the lower social classes that their experiences are of no interest to anyone and so performing their religious duty to the souls of the dead should be sufficient. In fact, recalling these experiences outside their close community would be tantamount to "the unnecessary reopening of old wounds". By contrast, the intelligentsia, as the Jedwabne debate or discussions centered around the museum in Markowa show, see the "reopening of wounds" as a public duty they perform to fulfill a social obligation to memory or satiate a need to continually reshape national and civic identity. At the same time, however, there is a constant need for new examples that will allow the intelligentsia to preserve the sense of importance and authenticity proposed by their narrative. This explains why they so enthusiastically turn to local histories that appear to be genuine and authentic.

We have also shown in the book that the interest shown by memory producers in local histories has arisen from the ongoing global quest for authentic "anchors of memory". On the one hand, as contemporary societies, we are faced with the overproduction of forms of remembrance and omnipresence of memory centered around us (in public space, media production, state rituals, and political discussions and conflicts). On the other hand, as many researchers of the contemporary situation underline, memory has become detached from day-to-day life, and so is seeking authentic and genuine anchorage points. When a vision of the past situates itself in a given landscape, it begins to create metaphors that are more real than their referents and becomes a part of the scenery that is genuinely 
experienced ${ }^{573}$. This process explains the global turn towards landscapes of memory and the quest for authentic, yet-to-be-discovered places of the kind perfectly exemplified by Kałków, Michniów, Jedwabne, or Markowa. These places do in fact possess histories yet to be fully investigated by professional historians that also seem to be "authentic", not only on a factographical level (enabling historical research to be evaluated) but also on an emotional-social level (as evidenced by the memory of a local community that is united through its common origin with the people it chooses to commemorate). This explains why such concrete places and microhistories enable experiencing of the past to become almost tangible.

These places possess one more important attribute - they are moral spaces. As we have shown in this book, the actions local communities undertake and memory markers they erect, such as the roadside crosses described in the chapter devoted to Jedwabne or the chapel in Reguly referred to in the introduction, rather than being simple memory markers, are repositories of values the group upholds. Consequently, authentic places possessing morally authentic landscapes of memory are becoming attractive to the state's historical policymakers. The role of these policymakers, as Michał Łuczewski, who was quoted in the introduction, writes, is to find histories that will help to build the national community's moral capital in the international arena. The Polish state's determined attempts to promote the Ulma Museum show how important accumulation of moral capital is in contemporary international politics ${ }^{574}$. At the same time, it shows what a valuable stake in this game local histories have become.

573 Simon Schama, Landscape and memory. Fontana Press: London, 1995, p. 61.

574 The Ulmas have not only been awarded the Yad Vashem Institute's Righteous Among the Nations medal, but are also sainthood candidates in the Catholic Church, so the moral capital they generate is even greater, hence the idea to create a branch of the Ulma Museum in New York. This location was not chosen by chance. It was important for the Polish government that the institution should be created in a place containing a strong and active Jewish community that has been loudly articulating their belief that the Poles bear a measure of responsibility for the Holocaust. By locating the museum in New York, the Polish government wants to influence and neutralize the effects of that community's stance. As the Deputy Minister of Culture, Jarosław Selin explained, "We plan in New York - for this, rather than Jerusalem or Tel Aviv, is the place where the most Jews in the world live - to construct a branch of the Ulma Family Museum of Poles Saving Jews, at a worthy site, in a central location in Manhattan, so this history will be in close proximity to this community". "Muzeum Polaków Ratujących Żydów będzie miało filię w USA. I to w prestiżowej lokalizacji na Manhattanie”, 20 February. Retrieved from http://niezalezna.pl/217516-muzeum-polakow-ratujacychzydow-bedzie-mialo-filie-w-usa-i-to-w-prestizowej-lokalizacji-na-manhattanie (last accessed 29 Sep. 2018). 



\section{List of Figures}

Fig. 1.1: The Golgotha of the Polish Nation in the Our Holy Cross Lady of Sorrows Sanctuary in Kałków-Godów. Photograph by Dariusz Bogumił.

Fig. 1.2: The mass grave of the victims of the November 1943 pacification. The plaque contains the inscription: "The place of eternal rest of 28 people murdered by the Nazis at the lodge, 11.XI.1943, Honor their memory!" Photograph by Dariusz Bogumił.

Fig. 1.3: The monument erected at the site of the mass pacification that took place in May 1943. The inscription provides the following information: "At this site on 24 May 1943 Nazis murdered 27 residents of the village of Żuchowiec. Hail to their Memory". The monument was erected in May 1970. Photograph by Dariusz Bogumił.

Fig. 1.4: The monument erected on site of the mass pacification that took place in May 1943. The inscription provides the following information: "A place sanctified by the martyrs' blood of 52 residents of the village of Gębice murdered by Nazis 24 May 1943. Honor to their Memory". Photograph by Marta Karkowska.

Fig. 1.5: The collective grave at the cemetery in Krynki, which was constructed in the 1980s and funded by donations from villagers. Photograph by Dariusz Bogumił.

Fig. 1.6: Pieta - a memorial alongside the entrance to the Our Holy Cross Lady of Sorrows Sanctuary in Kałków-Godów dedicated to those killed in action in the Holy Cross region during the war and the stone monument containing a plaque commemorating the victims of Żuchowiec and Gębice, the villages pacified in 1943. Photograph by Marta Karkowska.

Fig. 1.7: The Pantheon of Polish Peasants in the Our Holy Cross Lady of Sorrows Sanctuary in Kałków-Godów. Photograph by Dariusz Bogumił.

Fig. 2.1: The collective grave of victims of the pacification that took place in Michniów on 12th-13th July 1943. The inscription provides the following information: "The collective 
grave [containing] the remains of those undeservedly murdered and burned alive by the Germans on 12th and 13th July 1943 in Michniów". In the background, the Mausoleum of the Martyrdom of Polish Villages in Michniów is visible. Photograph by Dariusz Bogumił.

Fig. 2.2: The small brick chapel to the right, which was dedicated to St Margaret, was erected next to the collective grave in Michniów in 1953. Photograph by Dariusz Bogumił.

Fig. 2.3: Pieta Michniowska (The Michniów Pieta) erected in 1993. In the background, the Mausoleum of the Martyrdom of Polish Villages in Michniów is visible. Photograph by Dariusz Bogumił.

Fig. 3.1: The birch cross by the road from Orlikowo to Olszewo erected on the commune authorities' initiative in 2013 on the 150th anniversary of the January insurgents' march through Orlikowo under the command of Colonel Konstanty Ramotowski, known by the pseudonym Wawer. Photograph by Zuzanna Bogumił.

Fig. 3.2: The memorial by the path leading to the municipal cemetery commemorating the 180 people murdered within the Jedwabne Commune between 1939 and 1956 by the NKVD, Nazis and UB. It was erected in the nineties on the initiative of the commune authorities. Photograph by Zuzanna Bogumił. 166

Fig. 3.3: The memorial commemorating the Jews murdered in Jedwabne in 1941, erected on the initiative of the Polish state in 2001. Photograph by Zuzanna Bogumił.

Fig. 3.4: The Sybiraks Memorial erected on the commune authorities' initiative in the town center in 2003. Photograph by Zuzanna Bogumił.

Fig. 3.5: The Tomb of the Unknown Soldier in Jedwabne's municipal cemetery. Its restoration at the beginning of the 21 st century was privately funded by a parishioner. Photograph by Zuzanna Bogumił.

Fig. 4.1: Grave of the Ulma family at the Catholic cemetery in Markowa. Photograph by Marta Karkowska.

Fig. 4.2: Painting of the Ulma family located in the left nave of St Dorothy's Parish Church in Markowa. Photograph by Marta Karkowska. 
Fig. 4.3: The site where the Ulmas' house once stood and where they and the Jews they were hiding were killed on 24 March 1944. Photograph by Marta Karkowska.

Fig. 4.4: The Ulma family monument in Markowa. It was founded by the villagers and erected next to the Village of Markowa Skansen (see picture). In 2017 the monument was moved several hundred meters further on to the Orchard of Remembrance. Photograph by Dariusz Bogumił.

Fig. 4.5: The Ulma Family Museum of Poles Saving Jews in World War II in Markowa. Photograph by Dariusz Bogumił. 225 



\section{Bibliography}

Adamowski, Jan. "Motywacje stawiania krzyży i kapliczek przydrożnych." In: Krzyże i kapliczki przydrożne jako znaki społecznej, kulturowej i religijnej pamięci, eds. Jan Adamowski, Marta Wójcicka. Lublin: Wydawnictwo Uniwersytetu Marii Curie-Skłodowskiej, 2011, pp. 17-41.

Adamowski, Jan and Marta Wójcicka, eds. Krzyże i kapliczki przydrożne jako znaki społecznej, kulturowej i religijnej pamięci. Lublin: Wydawnictwo Uniwersytetu Marii Curie-Skłodowskiej, 2011.

Alexander, Jeffrey and Elizabeth Butler Breese. "Introduction: On Social Suffering and Its Cultural Construction." In: Narrating Trauma: On the Impact of Collective Suffering, eds. Ronald Eyerman, Jeffrey C. Alexander and Elizabeth Butler Breese. New York: Routledge, 2011, pp. xi-xxxv.

Ashis, Nandy. "History's Forgotten Doubles." History and Theory, Vol. 34, No. 2, 1995, pp. 44-66.

Assmann, Aleida. "1998 - między historią a pamięcią." Translated by Magdalena Saryusz-Wolska. In: Pamięć zbiorow i kulturowa; współczesna perspektywa niemiecka, ed. Magdalena Sarytusz-Wolska. Kraków: Universitas, 2009, pp. 142-173.

Assmann, Jan. Cultural Memory and Early Civilization: Writing, Remembrance, and Political Imagination. Cambridge: Cambridge University Press, 2011.

Augustyniak, Alicja (a selection of texts). Godni synowie naszej Ojczyzny: świadectwa nadesłane na apel Radia Maryja. Warsaw: Wydawnictwo Sióstr Loretanek, 2002.

Baraniecka-Olszewska, Kamila.The Crucified: Contemporary Passion Plays in Poland. Berlin/ Boston: De Gruyter, 2017.

Barnes, Harry Elmer and Howard Becker. Social Thought from Lore to Science. New York: Dover Publications, 1961.

Bartoszewski, Władysław and Zofia Lewinówna (ed.). Ten jest z ojczyzny mojej: Polacy z pomoca Żydom 1939-1945. Kraków: Znak, 1966.

Bauminger, Arieh Leon. The Righteous among the Nations. Warsaw: Wydawnictwo Naukowe PWN, 1994.

Bagley, Tennent H. Spy Wars: Moles, Mysteries, and Deadly Games. Yale: Yale University Press, 2007.

Bernard-Donals, Michael and Richard Glejzer. "Between Witness and Testimony: Survivor Narratives and the Shoah." College Literature, Vol. 27, No. 2, 2000, pp. 1-20. 
Bernhard, Michael and Jan Kubik, eds. Twenty Years after Communism: The Politics of Memory and Commemoration. Oxford: Oxford University Press, 2014.

Białczak, Adam. "Krzyże i kapliczki przydrożne zachodniej Kurpiowszczyzny." Zeszyty Naukowe OTN, Vol. XVI, 2002, pp. 253-280.

Bikont, Anna. My z Jedwabnego. Warsaw: Prószyński i S-ka, 2004.

Bikont, Anna. The Crime and the Silence: Confronting the Memory of the Burning of Jews by Their Neighbors in Wartime Jedwabne. Translated by Alissa Valles. New York: Farrar, Straus and Giroux, 2015.

Bilewicz, Michał and Katarzyna Jabłońska. "Dobrze być ofiarą? -rozmowa." Więź, Vol. 53, No. 2-3, 2010, pp. 35-43.

Blajer, Wojciech. “Z dziejów wsi Markowa - recenzja.” Rocznik Przemyski, Vol. 32, No. 1, 1996, pp. 141-147.

Blajer, Wojciech, Jacek Tejchma, eds. Markowa - sześć wieków tradycji: z dziejów kultury i społeczeństwa, Mielec: Zakład Poligraficzny Zbigniew Grajek, 2005.

Bogumił, Zuzanna. "Miejsce pamięci versus symulacja przeszłości - druga wojna światowa na wystawach historycznych." Kultura i Społeczeństwo, Vol. LV, No. 4, 2011, pp. 149-170.

Bogumił, Zuzanna. "The Blessed Jerzy Popiełuszko Museum in Warsaw: Between History and Religion." Cultures of History Forum. 12 Jan 2018. http://www.culture-of-history.uni-jena.de//exhibitions/poland/the-blessedjerzy-popieluszko-museum-in-warsaw-between-history-and-religion/ (16 Sept. 2018).

Bogumił Zuzanna and Andrzej Szpociński, eds. Stare i nowe tendencje w obszarze pamięci społecznej. Warsaw: Scholar, 2018.

Bogumił, Zuzanna, Joanna Wawrzyniak, Tim Buchen, Christian Ganzer and Maria Senina. The Enemy on Display. The Second World War in Eastern European Museums. Oxford and New York: Berghahn Books, 2015.

Borodziej, Włodzimierz. The Warsaw Uprising of 1944. Madison: University of Wisconsin Press, 2006.

Can, Ozan. "Religion and Cultural Memory: A Case Study of Roman Catholic Sacraments, Monumental Statues, and Iconography", Anthropology of Communication, 5 December 2017, Budapest Metropolitan University, manuscript.

Cappelletto, Francesca. "Long-Term Memory of Extreme Events: From Autobiography to History." The Journal of the Royal Anthropological Institute, Vol. 9, No. 2, 2003, pp. 241-260. 
Caruth, Cathy. Unclaimed Experience. Trauma, Narrative and History. Baltimore: Johns Hopkins University Press, 1995.

Casanova, José. Public Religions in the Modern World. Chicago: Chicago University Press, 1994.

Casanova, José. Religion, European Secular Identities and European Integration. 2004. http:/www.bpb.de/system/files/pdf/XLKRLX.pdf (25 Feb. 2016).

Casanova, José. “The Religious Situation in Europe." In: Secularization and the World Religions, eds. Hans Joas and Klaus Wiegandt. Liverpool: Liverpool University Press, 2009, pp. 206-227.

Charbonnier, Georges, ed. Conversations with Claude Lévi-Strauss. London: Cape, 1973.

Chodakiewicz, Marek Jan. The Massacre in Jedwabne, July 10, 1941: Before, During and After. Boulder: Columbia University Press, 2005.

Christensen, Karin Hyldal. The Making of the New Martyrs of Russia. Soviet Repression in Orthodox Memory. London \& New York: Routledge, 2017.

Chwiedź Tadeusz, Hieronima Dzierma, Mieczysław Pluta, Jerzy Koffer, Józef Panasiuk, Mateusz Hołownia and Dawid Gromadzki. Znaki Pamięci Polskiej Golgoty Wschodu województwa podlaskiego. Białystok: Buniak-Druk, 2015.

Cobel-Tokarska, Marta. Desert Island, Burrow, Grave: Wartime Hiding Places of Jews in Occupied Poland. Berlin, Bern, Bruxelles, New York, Oxford, Warsaw, Vienna: Peter Lang, 2018.

Coelho, João Pinto. Os Loucos da Rua Mazur. Alfragide: Leya, SA, 2017.

Czubryt-Borkowski Czesław and Jerzy Michasiewicz, eds., Przewodnik po upamiętnionych miejscach walk i męczeństwa: lata wojny 1939-1945, . Warsaw: Wydawnictwo "Sport i Turystyka", 1980.

Czubryt-Borkowski Czesław and Zygmunt Czarnocki [et al.], eds..Przewodnik po upamiętnionych miejscach walk i męczeństwa: lata wojny 1939-1945, Warsaw: Wydawnictwo "Sport i Turystyka”, 1988.

Czyżewski, Marek. "Debata na temat Jedwabnego oraz spór o 'politykę historyczną z punktu widzenia analizy dyskursu publicznego.” In: Pamięć i polityka historyczna. Doświadczenia Polski i jej sasiadów, eds. Sławomir M. Nowinowski, Jan Pomorski and Rafał Stobiecki. Łódź: Instytut Pamięci Narodowej, 2008.

Czyżewski, Marek. "Polski spór o Strach Jana Tomasza Grossa w perspektywie 'pośredniczącej' analizy dyskursu." Studia Socjologiczne, Vol. 3, No. 194, 2009, pp. 5-26.

Danilecki, Tomasz, ed. Podziemie Niepodległościowe w województwie białostockim. Warsaw: IPN, 2004. 
Datner, Szymon. Walka i Zagłada białostockiego getta. Łódź: Wojewódzka Żydowska Komisja Historyczna w Białymstoku, 1946.

Datner Szymon. Las sprawiedliwych. Karta $z$ dziejów ratownictwa Żydów w okupowanej Polsce. Warsaw: "Książka i Wiedza", 1968.

Davis, Norman. God's Playground: A History of Poland, Vol. 1: The Origins to 1795. New York: Columbia University Press, 1982.

Davis, Norman. Heart of Europe: The Past in Poland's Present. Oxford: Oxford University Press, 2001.

Davis, Norman. God's Playground: A History of Poland, Vol. 2: 1795 to the Present (Revised 2nd Edition). New York: Columbia University Press, 2005.

Dobosz, Stanisław. “W walce z okupantem hitlerowskim”. In: $Z$ dziejów wsi Markowa, ed. Janusz Półćwiartek. Rzeszów: Towarzystwo Przyjaciół Markowej, 1993, pp. 92-115.

Domański, Tomasz. "I nie widziatem ich więcej wśród żywych..." Pacyfikacja Michniowa 12 i 13 lipca 1943 r. w dokumentach i relacjach. Kraków: IPN, 2013.

Domański, Tomasz and Andrzej Jankowski. Represje niemieckie na wsi kieleckiej 1939-1945. Kielce: IPN, 2011.

Domber, Gregory. Empowering Revolution: America, Poland, and the End of the Cold War (The New Cold War History). Chapel Hill: The University of North Carolina Press, 2014.

Drozdowski, Marian Marek. Warszawa w obronie Rzeczypospolitej. Czerwiecsierpień 1920. Warsaw: Warszawska Oficyna Wydawnicza “Gryf”, Instytut Historii PAN, 1993.

Drożdż-Szczybura, Małgorzata. Wybrane problemy ochrony krajobrazu kulturowego polskiej wsi. Kraków: Wydawnictwo Politechniki Krakowskiej, 2000.

Duncan, Peter. Russian Messianism. Third Rome, Revolution, Communism and After. London: Routledge, 2000.

Durlej, Stanisław and Janusz Gmitruk. Panteon chłopów polskich na ziemi świętokrzyskiej. Kielce and Warsaw: Ludowe Towarzystwo Naukowo-Kulturalne Oddział w Kielcach, Muzeum Historii Polskiego Ruchu Ludowego, 2008.

Engelking, Barbara. “'Po zamordowaniu udaliśmy się do domu'. Wydawanie i mordowanie Żydów na wsi polskiej w latach 1942-1945.” In: Zarys Krajobrazu. Wieś polska wobec Zagłady Żydów 1942-1945, eds. Barbara Engelking and Jan Grabowski. Warsaw: Stowarzyszenie Centrum Badań nad Zagładą Żydów, 2011, p. 259-311. 
Engelking, Barbara and Jan Grabowski, eds. Zarys Krajobrazu. Wieś polska wobec Zagłady Żydów 1942-1945. Warsaw: Stowarzyszenie Centrum Badań nad Zagładą Żydów, 2011.

Engelking, Barbara, Jan Grabowski and Dariusz Libionka, eds. Dalej jest noc Losy Żydów w wybranych powiatach okupowanej Polski. Vol. 1 and 2. Warsaw: Centrum Badań nad Zagładą Żydów, 2018.

Esbenshade, Richard S. "Remembering to Forget: Memory, History, National Identity in Postwar East-Central Europe." Representations, Vol. 49, 1995, pp. 72-96.

Espín, Orlando O. and James B. Nickoloff. An Introductory Dictionary of Theology and Religious Studies. Collegeville: Liturgical Press, 2007.

Etkind, Aleksander. Warped Mourning. Stories of the Undead in the Land of the Unburied. Stanford: Stanford University Press, 2013.

Etkind, Aleksander, Rory Finnin, Uilleam Blacker, Julie Fedor, Simon Lewis, Maria Malksoo and Matilda Mroz. Remembering Katyn. Cambridge: Polity, 2012.

Forecki, Piotr. Spór o Jedwabne. Analiza debaty publicznej. Poznań:

Wydawnictwo Naukowe Instytutu Nauk Politycznych i Dziennikarstwa UAM, 2008.

Forecki, Piotr. Od Shoah do Strachu. Spory o polsko-żydowska przeszłość i pamięć $w$ debatach publicznych. Poznań: Wydawnictwo Poznańskie, 2010.

Forecki, Piotr. "Muzeum Zgody w Markowej." Zagłada Żydów. Studia $i$ Materiały, Vol. 12, 2016, pp. 643-652.

Foucault, Michael. The Order of Things: An Archaeology of the Human Sciences. New York: Pantheon Books, 1970.

Friszke, Andrzej. Polska. Losy państwa i narodu 1939-1989. Warsaw: Iskry, 2003. Giddens, Anthony. The Consequences of Modernity. Cambridge: Polity Press, 1999.

Głowacka-Grajper, Małgorzata. „Pamięć jako kapitał społeczności lokalnej. Narracje o Bitwie Warszawskiej 1920 roku w Radzyminie." In: Stare i nowe tendencje w obszarze pamięci społecznej, eds. Zuzanna Bogumił and Andrzej Szpociński. Warsaw: Scholar, 2018, pp. 318-352.

Gmitruk, Janusz. "Geneza Wielkiego Strajku Chłopskiego w sierpniu 1937 roku." In: Wielki Strajk Chłopski w 1937 roku. Uwarunkowania $i$ konsekwencje, ed. Wacław Wierzbieniec. Rzeszów: Wydawnictwo Uniwersytetu Rzeszowskiego, 2008.

Gmitruk, Janusz and Longin Kaczanowski. Płonęty niebo i ziemia/ Mauzoleum Walki i Męczeństwa Wsi Polskiej w Michniowie. Warsaw and Michniów: MHPRL, 1998. 
Górny, Grzegorz and Norman Davis. Sprawiedliwi. Jak Polacy ratowali Żydów przed Zagłada. Warsaw: Rosikon Press, 2013.

Grabowski, Jan. Judenjagd. Polowanie na Żydów 1942-1945. Studium dziejów pewnego powiatu. Warsaw: Stowarzyszenie Centrum Badań nad Zagładą Żydów, 2011a.

Grabowski, Jan. “Prawda leży w mogiłach.” Więź, Vol. 8-9, No. 634, 2011d, pp. 103-106.

Grabowski, Jan and Dariusz Libionka. "Bezdroża polityki historycznej. Wokół Markowej, czyli o czym nie mówi Muzeum Polaków Ratujących Żydów podczas II Wojny Światowej im. Rodziny Ulmów." Zagłada Żydów. Studia i Materiaty, Vol. 12, 2016, pp. 619-642.

Grabowski, Jan and Dariusz Libionka. "Distorting and Rewriting the History of the Holocaust in Poland: The Case of the Ulma Family Museum of Poles Saving Jews during World War II in Markowa." Yad Vashem Studies, Vol. 45, No. 1, 2017, pp. 29-60.

Gross, Tadeusz. Neighbors: The Destruction of the Jewish Community in Jedwabne, Poland. Princeton, Oxford: Princeton University Press, 2001.

Grynberg, Michał. Ksiega sprawiedliwych. Warsaw: Wydaw. Naukowe PWN, 1993.

Grzesiuk-Olszewska, Irena. Polska rzeźba pomnikowa w latach 1945-1995. Warsaw: Wydawnictwo Neriton, 1995.

Grzesiuk-Olszewska, Irena. “Pomniki stolicy ostatniego dziesięciolecia." In: Warszawa o czym mówia pomniki i kamienie, eds. Karol Mórawski and Andrzej Stawarz. Warsaw: Muzeum Niepodległości, 2000, pp. 276-284.

Gubała-Czyżewska, Joanna. "Upamiętnienie Holocaustu w Łodzi. Stare i nowe tendencje." In: Stare i nowe tendencje w obszarze pamięci społecznej, eds. Zuzanna Bogumił and Andrzej Szpociński. Warsaw: Scholar, 2018, pp. $77-109$.

Halbwachs, Maurice. On Collective Memory. Chicago: Chicago University Press, 1992.

Heins, Volker and Andreas Langenhol. "A Fire That Doesn't Burn? The Allied Bombing of Germany and the Cultural Politics of Trauma." In: Narrating Trauma: On the Impact of Collective Suffering, eds. Ronald Eyerman, Jeffrey C. Alexander and Elizabeth Butler Breese. New York: Routledge, 2011, pp. 3-26.

Hervieu-Léger, Daniele. Religion as a Chain of Memory. (Translated from La religion pour mémoire by Simon Lee.). New Brunswick, New Jersey: Rutgers University Press, 2000. 
Hildebrandt, Gisela. Siedlungsgeographische Untersuchungen im Gebiet der deutsch-mittelalterrlichen Waldhufend"orfer um Landshut: Markowa, Gać und Bialoboki. Krakau: Institut für Deutsche Ostarbeit, 1942.

Hirsch, Marianne. The Generation of Postmemory. Writing and Visual Culture After the Holocaust. New York: Columbia University Press, 2012.

Iranek-Osmecki, Kazimierz. Kto ratuje jedno życie... Polacy i Żydzi 1939-1945. Warsaw: Instytut Pamięci Narodowej, 2009.

Janicka, Elżbieta. Festung Warschau. Warsaw: Wydawnictwo Krytyki Politycznej, 2011.

Janion, Maria. Do Europy - tak, ale z naszymi zmarlymi. Warsaw: Wydawnictwo Sic! 2000.

Jankowski, Andrzej and Włodzimierz Sadowski. Kielce i okolice. Przewodnik. Warsaw: Sport i Turystyka, 1983.

Jarosz, Aleksandra. “Zbrodnia katyńska. niespójna pamięć w kontekście miejsc pamięci o Katyniu na terenie Warszawy." In: Stare i nowe tendencje w obszarze pamięci społecznej, eds. Zuzanna Bogumił and Andrzej Szpociński. Warsaw: Scholar, 2018, pp. 145-176.

Kaczanowski, Longin. Zagłada Michniowa. Warsaw: Muzeum Historii Polskiego Ruchu Ludowego i Muzeum Wsi Kieleckiej, 2013.

Kaczanowski, Longin and Bogusław Paprocki. Miejsca pamięci narodowej w województwie kieleckim 1939-1945. Biuro Dokumentacji Zabytków: Kielce, 1989.

Kaczmarek, Olga. "Jedwabne - wiedza obrzeży." Kultura Wspótczesna, Vol. 3, No. 87, 2015, pp. 37-44.

Kaindl, Raimund Friedrich. Geschichte der Deutschen in den Karpatenländern. Gotha: Friedrich Andreas Perthes, Vol. 3, 1907.

Kapralski, Sławomir. "The Jedwabne Village Green?: The Memory and CounterMemory of the Crime." History and Memory, Vol. 18, No. 1, 2006, pp. 179-194.

Kapralski, Sławomir. Naród z popiołów. Pamięć Zagłady a tożsamość Romów. Warsaw: Wydawnictwo Naukowe Scholar, 2012.

Karkowska, Marta. "Międzypokoleniowe Transmisje pamięci. Na podstawie badań we wsiach świętokrzyskich." Studia Socjologiczne, Vol. 222, 2016a, pp. 101-132.

Karkowska, Marta. "Pamięć społeczności lokalnej w jej publicznej i prywatnej odsłonie. Przykład Michniowa." In: Przemiany kulturowe we współczesnej Polsce: ramy, właściwości, epizody, ed. Joanna Kurczewska. Warsaw: Wydawnictwo IFiS PAN, 2016b, pp. 376-401. 
Kieniewicz, Stefan. "Polish Society and the Insurrection of 1863.” Past \& Present, Vol. 37, 1967, pp. 130-148.

Kobielska, Maria. Polska kultura pamięci w XXI wieku: dominanty. Zbrodnia katyńska, powstanie warszawskie i stan wojenny. Warsaw: IBL Wydawnictwo, 2016.

Kołomańska, Ewa. Michniów. Mauzoleum martyrologii wsi polskich. Kielce: Muzeum Wsi Kieleckiej, 2010.

Korzeniewski, Bartosz. "World War II in the Politics of Memory of the Polish People's Republic 1944-1970.” In: World War II and Two Occupations. Dilemmas of Polish Memory, eds. Anna Wolff-Powęska, Piotr Forecki, Frankfurt am Main, Berlin, Bern, Bruxelles, New York, Oxford, Vienna: Peter Lang, 2016, pp. 61-80.

Kosicki, Piotr. "Forests, Families, and Films: Polish Memory of Katyń, 19432015." East European Politics and Societies and Cultures, Vol. 29, No. 4, 2015, pp. $730-760$.

Kostov, Chris. The Communist Century: From Revolution to Decay: 1917 to 2000. Luton: AUK Authors, 2015.

Kucia, Marek, Marta Duch-Dyngosz and Mateusz Magierowski. "The Collective Memory of Auschwitz and World War II among Catholics in Poland: A Qualitative Study of Three Communities," History and Memory, Vol. 25, No. 2, 2013, pp. 132-173.

Kunert, Andrzej Krzysztof and Andrzej Friszke. “Żegota”. Rada Pomocy Żydom 1942-1945. Wybór dokumentów. Warsaw: ROPWiM, 2002.

Kurek, Ewa. Jedwabne - anatomia kłamstwa. Lublin: Wydawnictwo Clio, 2018.

Kurkowska-Budzan, Marta. "Imaging Jedwabne. The Symbolic and the Real." Polish Sociological Review, Vol. 1, No. 137, 2002, pp. 113-117.

Kurkowska-Budzan, Marta. Historia zwykłych ludzi. Współczesna angielska historiografia dziejów społecznych. Kraków: Towarzystwo Wydawnicze "Historia Iagellonica", 2003.

Kurkowska-Budzan, Marta. "My Jedwabne." In: The Neighbors Respond. The Controversy over the Jedwabne Massacre in Poland, eds. Antony Polonsky and Joanna B. Michlic. Princeton and Oxford: Princeton University Press, 2004, pp. 200-206.

Kurkowska-Budzan, Marta. "Jedwabne and Wizna. Monuments and Memory in the Łomża Region." Polin. Studies in Polish Jewry, Vol. 20, 2007, pp. 244-270.

Kurkowska-Budzan, Marta. Antykomunistyczne podziemie zbrojne na Białostocczyźnie: analiza współczesnej symbolizacji przeszłości. Kraków: Towarzystwo Wydawnicze "Historia Iagellonica", 2009. 
Kwiatkowski, Piotr. Pamięć zbiorowa społeczeństwa polskiego w okresie transformacji. Warsaw: Scholar, 2008.

Kwiatkowski, Piotr. "World War II as Collective Experience for Polish Society." In: World War II and Two Occupations. Dilemmas of Polish Memory, eds. Anna Wolff-Powęska, Piotr Forecki, Frankfurt am Main, Berlin, Bern, Bruxelles, New York, Oxford, Vienna: Peter Lang, 2016, pp. 13-38.

Leder, Andrzej. Prześniona rewolucja. Ćwiczenia z logiki historycznej. Warsaw: Wydawnictwo Krytyki Politycznej, 2013.

Le Goff, Jacques. History and Memory. New York: Columbia University Press, 1996.

Leociak, Jacek. Ratowanie. Opowieści Polaków i Żydów. Kraków: Wydawnictwo Literackie, 2010.

Leociak, Jacek. "Warszawa upamiętnia Sprawiedliwych.” Nigdy Więcej, Vol. 22, 2016. http://www.nigdywiecej.org/pdf/pl/pismo/22/warszawa_upamietnia_ sprawiedliwych.pdf.

Libionka, Dariusz. "Duchowieństwo diecezji łomżyńskiej wobec antysemityzmu i zagłady Żydów." In: Wokół Jedwabnego. Tom 1. Studia, eds. Paweł Machcewicz and Krzysztof Persak. Warsaw: Instytut Pamięci Narodowej, 2002, pp. 105-128.

Libionka, Dariusz. "Polskie studia i piśmiennictwo na temat zorganizowanej i indywidualnej pomocy Żydom (1945-2008)." In: Zagłada Żydów. Studia i Materiały. Warsaw: Centrum Badań nad Zagładą Żydów, No. 4, 2008, pp. 17-80.

Lim, Jie-Hyun. "Victimhood Nationalism and History Reconciliation in East Asia." History Compass, Vol. 8, No. 1, 2008, pp. 1-10.

Lim, Jie-Hyun. "Victimhood Nationalism in Contested Memories: National Mourning and Global Accountability." In: Memory in a Global Age. Discourses, Practices and Trajectories, eds. Aleida Assmann and Sebastian Conrad. Houndmills: Palgrave Macmillan, 2010, pp. 138-162.

Lityński, Adam. Historia prawa Polski Ludowej. Warsaw: LexisNexis, 2005.

Lubańska, Magdalena. "Problemy etnograficznych badań nad religijnością." In: Religijność Chrześcijan obrządku Wschodniego na pograniczu polsko-ukraińskim, ed. Magdalena Lubańska. Warsaw: Wydawnictwo DIG, 2007, pp. 7-31.

Lubańska, Magdalena. "Postmemory of Killings in the Woods at Dębrzyna (1945-46): A Post-Secular Anthropological Perspective," Ethnologia Polona, Vol. 38, 2018, pp. 15-45.

Łuczewski, Michał. Odwieczny naród. Polak i katolik w Żmiacej. Toruń: Wydawnictwo Naukowe Umk, 2012. 
Łuczewski, Michał. Kapitał moralny. Polityki historyczne w późnej nowoczesności. Kraków: Ośrodek Myśli Politycznej, 2017.

Maciejczak, Zuzanna. "Murale na warszawskim Muranowie jako nośniki pamięci miejsca." In: Stare i nowe tendencje w obszarze pamięci społecznej, eds. Zuzanna Bogumił and Andrzej Szpociński. Warsaw: Scholar, 2018, pp. 196-232.

Machcewicz, Paweł. “Wokół Jedwabnego." In: Wokół Jedwabnego. Tom 1. Studia, eds. Paweł Machcewicz and Krzysztof Persak. Warsaw: Instytut Pamięci Narodowej, 2002, pp. 9-61.

Madurowicz, Mikołaj. Sfera sacrum w przestrzeni miejskiej Warszawy. Warsaw: Wydawnictwo Akademickie DIALOG, 2002.

Magierowski, Mateusz. ““Trauma sprawców” jako przedmiot społecznie kształtowanych procesów pamiętania i zapominania w społeczności lokalnej. Przypadek Gniewczyny." Studia Humanistyczne AGH, Vol. 13, No. 3, 2014, pp. 247-258.

Magierowski, Mateusz. "Historyczne, kulturowe i społeczne czynniki kształtujące społeczną (nie-) pamięć o zbrodniach popełnionych przez Polaków na przedstawicielach innych grup etnicznych w Gniewczynie i Pawłokomie." Sensus Historiae, Vol. XX, 2015, pp. 49-60.

Magierowski, Mateusz. "(A)symmetry of (Non-)memory. The Missed Opportunity to Work Through the Traumatic Memory of the Polish-Ukrainian Ethnic Conflict in Pawłokoma." East European Politics and Societies and Cultures, Vol. 30, No. 4, 2016, pp. 766-784.

Magierowski, Mateusz. "Between Dissonance and Convergence: The Dynamics of Interactions between Vernacular and Official (Non-)Memories of the Mass Murder of Germans by Poles in Nieszawa." Polish Sociological Review, Vol. 1, No. 197, 2017, pp. 83-94.

Malacki, Zygmunt, Grzegorz Pfeifer and Ewa Anna Zając. Muzeum Sługi Bożego Ks. Jerzego Popiełuszki. Warsaw: Wydawnictwo Sióstr Loretanek, 2005.

Malicki, Krzysztof. Poza wspólnota pamięci Życie i Zagłada Żydów w pamięci mieszkańców regionu podkarpackiego. Warsaw: IFiS PAN, 2017.

Markiel, Tadeusz and Alina Skibińska, 'Jakie to ma znaczenie, czy zrobili to $z$ chciwości?’: zagłada domu Trynczerów. Warsaw: Stowarzyszenie Centrum Badań nad Zagładą Żydów, 2011.

Marschall, Sabine. "Collective Memory and Cultural Difference: Official vs. Vernacular Forms of Commemorating the Past." Safundi. The Journal of South African and American Studies, Vol. 14, No. 1, 2013, pp. 77-92.

Matusak Piotr. Ruch oporu w Polsce: 1939-1945. Katowice: KAW, 1987.

Miernik, Ryszard. Pieśń o Michniowie. Łódź: Wydawnictwo Łódzkie, 1970. 
Misztal, Henryk. Prawo kanonizacyjne według ustawodawstwa Jana Pawła II. Instytucje kanonizacyjnego prawa materialnego. Zarys historii procedury kanonizacyjnej. Postepowanie $w$ diecezji i Kongregacji. Wzory pism $i$ formularzy. Lublin-Sandomierz: Wydawnictwo Diecezjalne, 1997.

Mithander, Conny, John Sundholm and Arien Velicu, eds. European Cultural Memory Post-89. Amsterdam and New York: Rodopi, 2013.

Mróz, Lech. "Niepamięć nie jest zapomnieniem. Cyganie-romowie a Holocaust." Przeglad Socjologiczny, Vol. 2, 2000, pp. 89-114.

Namysło, Aleksandra, ed. “Kto w takich czasach Żydów przechowuje?...” Polacy niosacy pomoc ludności żydowskiej w okresie okupacji niemieckiej. Warsaw: Instytut Pamięci Narodowej, 2009.

Niedźwiedź, Anna. The Image and the Figure: Our Lady of Częstochowa in Polish Culture and Popular Religion. Kraków: Jagiellonian University Press, 2010.

Nijakowski, Lech Michał. Domeny symboliczne: Konflikty narodowe i etniczne w wymiarze symbolicznym. Warsaw: Wydawnictwo Naukowe Scholar, 2006.

Nijakowski Lech Michał. "Pamięć o II wojnie światowej a relacje Polaków z innymi narodami.” In: Między codziennością a wielką historią. Druga wojna światowa w pamięci zbiorowej społeczeństwa polskiego, eds. Piotr T. Kwiatkowski, Lech M. Nijakowski, Barbara Szacka and Andrzej Szpociński. Warsaw: Scholar, 2010, pp. 239-286.

Niziołek, Maria. "Gdzie jest miejsce dla polskich Sprawiedliwych? Strategie pamięci na warszawskim Muranowie." Teksty Drugie, Vol. 1, 2014, p. 127-141.

Nora, Pierre. "Between Memory and History: Les Lieux de Memoire." Representations, Vol. 26, 1989, pp. 7-24.

Nora, Pierre. “Czas Pamięci.” Respublika Nowa, Vol. 7, No. 153, 2007, pp. 37-43.

Nowak, Jacek. Społeczne reguły pamiętania. Antropologia pamięci zbiorowej. Kraków: Nomos, 2011.

Nowak, Jerzy Robert. Sto kłamstw J. T. Grossa o Jedwabnem i żydowskich sasiadach. Warsaw: Wydawnictwo von Borowiecky, 2001.

Nowicka, Magdalena. "Dynamika pamięci publicznej. Debata wokół książki Jana Tomasza Grossa a wybrane spory o pamięć zbiorową." Kultura i Społeczeństwo, Vol. 3, 2014, pp. 237-258.

Nowik, Grzegorz. Wojna światów. 1920 - Bitwa Warszawska. Poznań: G\&P Oficyna Wydawnicza, Muzeum Józefa Piłsudskiego w Sulejówku, 2011.

Obara, Tadeusz and Stanisław Durlej. Męczeństwo i pamięć. Kielce: Ludowe Towarzystwo Naukowo-Kulturalne, 2001.

Obirek, Stanislaw. "Intellectuals and Catholicism in Today's Poland." Dialogue \& Universalism, Vol. 13, No. 5, 2003, pp. 77-86. 
Obrębska, Karolina. "Muzeum ks. Jerzego Popiełuszki w Warszawie jako miejsce kształtowania tożsamości społecznej poprzez doświadczenie religijne." In: Stare i nowe tendencje w obszarze pamięci społecznej, eds. Zuzanna Bogumił and Andrzej Szpociński. Warsaw: Scholar, 2018, pp. 233-263.

Olick, Jeffrey K. "Genre Memories and Memory Genres: A Dialogical Analysis of May 8, 1945 Commemorations in the Federal Republic of Germany." American Sociological Review, Vol. 64, 1999, pp. 381-402.

Olick, Jeffrey K. The Politics of Regret. On Collective Memory and Historical Responsibility. New York: Routledge, 2007.

Onacik, Jan. Przewodnik po miejscach walk i męczeństwa woj. białostockiego, lata wojny 1939-1945. Warsaw: Wydawnictwo Sport i Turystyka, 1970.

Oryszczszyn, Radosław. "Postawy i sympatie polityczne mieszkańców Polski północno-wschodniej po 1989 r." In: Między systemami: społeczeństwo Polski pótnocno-wschodniej wobec przemian ustrojowych 1989 roku: studia $i$ materiały, eds. Marcin Markiewicz and Anna Pyżewska. Białystok: Instytut Pamięci Narodowej, Oddział w Białymstoku, 2014.

Paczkowski, Andrzej. Pót wieku dziejów Polski. Warsaw: Wydawnictwo Naukowe PWN, 2005.

Pałyga, Jan. Golgota. Ząbki: Wydawnictwo Apostolicum, 1996.

Pamięć wiecznie żywa. 40 lat działalności Rady Ochrony Pomników Walki i Męczeństwa 1947-1987. Warsaw: Rada Ochrony Pomników Walki i Męczeństwa, 1988.

Pawełczyńska, Anna. Żywa historia - pamięć i ocena lat okupacji. Warsaw: OBOPSP, 1977.

Pawlak-Paluszek, Jolanta. "Świat świątków i wspomnień - kapliczki świadkami dziejów ziemi chełmskiej.” In: Krzyże i kapliczki przydrożne jako znaki społecznej, kulturowej i religijnej pamięci, eds. Jan Adamowski and Marta Wójcicka. Lublin: Wydawnictwo Uniwersytetu Marii Curie-Skłodowskiej, 2011, pp. 287-294.

Persak, Krzysztof. "Akta postępowań cywilnych z lat 1947-1949 w sprawach dotyczących zmarłych żydowskim mieszkańców Jedwabnego." In: Wokót Jedwabnego. Tom 2. Dokumenty, eds. Paweł Machcewicz and Krzysztof Persak. Warsaw: Instytut Pamięci Narodowej, 2002a, pp. 375-413.

Persak, Krzysztof. "Akta procesu z 1949 roku dwudziestu dwóch oskarżonych o udział w zbrodni na ludności żydowskiej w Jedwabnem." In: Wokół Jedwabnego. Tom 2. Dokumenty, eds. Paweł Machcewicz and Krzysztof Persak. Warsaw: Instytut Pamięci Narodowej, 2002, pp. 415-712.

Persak Krzysztof, "Akta procesu z 1953 roku Józefa Sobuty oskarżonego o udział w zbrodn na ludności żydowskiej w Jedwabnem." In: Wokót 
Jedwabnego. Vol. 2. Dokumenty, eds. Paweł Machcewicz and Krzysztof Persak. Warsaw: Instytut Pamięci Narodowej, 2002c, pp. 713-816.

Persak, Krzysztof. "Akta śledztwa z lat 1967-1974 prowadzonego przez Okręgową Komisję Badania Zbrodni Hitlerowskich w Białymstoku w sprawie zbrodni na ludności żydowskiej w Jedwabnem." In: Wokót Jedwabnego. Tom 2. Dokumenty, eds. Paweł Machcewicz and Krzysztof Persak. Warsaw: Instytut Pamięci Narodowej, 2002d, pp. 817-862.

Persak, Krzysztof. “Wstęp.” In: Zarys Krajobrazu. Wieś polska wobec Zagłady Żydów 1942-1945, eds. Engelking Barbara and Jan Grabowski. Warsaw: Stowarzyszenie Centrum Badań nad Zagładą Żydów, 2011, pp. 7-29.

Peters, Florian. "Towards a Balanced Tribute to the Polish Righteous? The Ulma Family Museum of Poles Saving Jews in Markowa." Cultures of History Forum. 8 Dec. 2016. http://www.culture-of-history.uni-jena.de (9 July 2018).

Pieńczak, Agnieszka. "Wybrane kapliczki i krzyże przydrożne jako pomniki pamięci w krajobrazie kulturowym Śląska Cieszyńskiego.” In: Krzyże i kapliczki przydrożne jako znaki społecznej, kulturowej i religijnej pamięci, eds. Jan Adamowski and Marta Wójcicka. Lublin: Wydawnictwo Uniwersytetu Marii Curie-Skłodowskiej, 2011, pp. 153-166.

Pilichowski, Czesław. Obozy hitlerowskie na ziemiach polskich 1939-1945. Informator encyklopedyczny. Warsaw: Państwowe Wydawnictwo Naukowe, 1979.

Półćwiartek, Janusz, ed. $Z$ dziejów wsi Markowa. Rzeszów: Towarzystwo Przyjaciół Markowej, 1993.

Półtorak, Witold and Grzegorz Bielec. "Znaczenie tragicznych wydarzeń historycznych dla turystyki na przykładzie rodziny Ulmów w Markowej.” In: Turystyka. Moda na sukces, eds. Joanna Kowalczyk-Anioł and Marzena Makowska-Iskierka. Łódź: Uniwersytet Łódzki, 2012, pp. 135-146.

Portnov, Andrii. "Clash of Victimhoods: The Volhynia Massacre in Polish and Ukrainian Memory." 16 Nov. 2016. https://www.opendemocracy.net/ od-russia/andrii-portnov/clash-of-victimhood-1943-volhynian-massacrein-polish-and-ukrainian-culture (9 July 2018).

Potocki, Andrzej. Żydzi w Podkarpackiem. Rzeszów: Wydawnictwo Libra, 2004.

Przewodnik po upamiętnionych miejscach walk i męczeństwa: lata wojny 19391945. Warsaw: Wydawnictwo Sport i Turystyka, 1964.

Rączy, Elżbieta. "Stosunki polsko-żydowskie w latach drugiej wojny światowej na Rzeszowszczyźnie.” In: Polacy i Żydzi pod okupacja niemiecka 1939-1945, ed. Andrzej Żbikowski. Warsaw: Instytut Pamięci Narodowej, 2006. 
Rejestr miejsc i faktów zbrodni popetnionych przez okupanta hitlerowskiego na ziemiach polskich w latach 1939-1945. Województwo kieleckie. Warsaw: Ministerstwo Sprawiedliwości, Główna Komisja Badania Zbrodni Hitlerowskich w Polsce, 1980.

Rejestr miejsc i faktów zbrodni popetnionych przez okupanta hitlerowskiego na ziemiach polskich w latach 1939-1945. Województwo rzeszowskie.

Warsaw: Ministerstwo Sprawiedliwości, Główna Komisja Badania Zbrodni Hitlerowskich w Polsce, 1984.

Richie, Alexandra. Warsaw 1944: Hitler, Himmler, and the Warsaw Uprising. New York: Farrar, Straus and Giroux, 2013.

Rothberg, Michael. Multidirectional Memory. Remembering the Holocaust in the Age of Decolonization. Stanford: Stanford University Press, 2009.

Ryszka, Czesław. Kałków-Godów: Sanktuarium pod Świętym Krzyżem. Warsaw: Wydawnictwo Sióstr Loretanek, 2002.

Ryszka, Czesław. Sanktuarium pod Świętym Krzyżem: Kałków-Godów. Kraków and Radom: Wydawnictwo Sióstr Loretanek, 2007.

Rzepliński, Andrzej. "Ten jest z ojczyzny mojej? Sprawy karne oskarżonych o wymordowanie Żydów w Jedwabnem w świetle zasady rzetelnego procesu." In: Wokół Jedwabnego. Tom 1. Studia, eds. Paweł Machcewicz and Krzysztof Persak. Warsaw: Instytut Pamięci Narodowej, 2002, pp. 353-459.

Schama, Simon. Landscape and memory. Fontana Press: London, 1995.

Sekerdej, Kinga, Agnieszka Pasieka and Marta Warat. "Popular Religion and Postsocialist Nostalgia. Lichen as a Polysemic Pilgrimage Centre in Poland." The Polish Sociological Review, Vol. 4, No. 160, 2007, pp. 431-444.

Sendyka, Roma. "Pryzma - zrozumieć nie-miejsce pamięci (non-lieux de mémoire)." Teksty Drugie, Vol. 1/2, 2014, pp. 323-344.

Sendyka, Roma. "Niepamięć albo o sytuowaniu wiedzy w formach pamiętania." Teksty Drugie, Vol. 6, 2016, pp. 250-267.

Sendyka, Roma. "Nie-miejsca pamięci i ich nie-ludzkie pomniki." Teksty Drugie, Vol. 2, 2017, pp. 86-108.

Sędziak, Zdzisław. "Napiętnowani znakiem śmierci." Ziemia łomżyńska, Vol. 2, 1986, pp. 185-197.

Siarko, Vitali. Teologia męczeństwa w ujęciu Jana Pawła II. Kraków: Uniwersytet Papieski Jan Pawła II, 2013.

Siomkajło, Alina. Katyń w pomnikach świata. Warsaw: Agencja Wydawnicza CB, 2002. 
Sitarek, Adam, Michał Trębacz and Ewa Wiatr, eds. Zagłada Żydów na polskiej prowincji. Łódź: Wydawnictw Uniwersytetu Łódzkiego, 2012.

Skibińska Alina. "Guide to the Sources on the Holocaust in Occupied Poland (Translated, revised and updated edition of the original Polish Źródła do badań nad zagłada Żydów na okupowanych ziemiach polskich by Alina Skibińska, Warsaw, 2007)”. 4 Aprl. 2019. https://jri-poland.org/help/Sourceson-the-Holocaust-in-Occupied-Poland.pdf

Skibiński, Paweł, Tomasz Wiścicki and Michał Wysocki. Polityka czy propaganda. PRL wobec historii. Warsaw: Muzeum Historii Polski, 2009.

Snyder, Timothy. Bloodlands: Europe Between Hitler and Stalin. New York: Basic Books, 2010.

"Sobór Watykański II, Konstytucja dogmatyczna o Kościele 'Lumen gentium."' 21 Nov. 1964. In. Sobór Watykański II, Konstytucje Dekrety Deklaracje. Poznań: Pallottinum, 2002.

Stangl, Paul. "The Vernacular and the Monumental: Memory and Landscape in Post-war Berlin.” GeoJournal, Vol. 73, No. 3, 2008, pp. 245-253.

Stefanek, Stanisław. "Miłość buduje historię." Ziemia Łomżyńska, 2001, No. 6, pp. 433-439.

Steinlauf, Michael C. "Poland." In: The World Reacts to the Holocaust, ed. David S. Wyman. Baltimore and London: The Johns Hopkins University Press, 1996.

Stola, Dariusz. “The Anti-Zionist Campaign in Poland 1967-1968." http://web. ceu.hu/jewishstudies/pdf/02_stola.pdf (17 Sept. 2018).

Strzembosz, Tomasz. "Jedwabne 1941." Translated by Mariusz Wesolowski. 2000. http://www.antyk.org.pl/ojczyzna/jedwabne/strzembosz.htmhttp:// www.antyk.org.pl/ojczyzna/jedwabne/strzembosz.htm/ (1 June 2018).

Sułek, Antoni. "Both Researcher and Second Generation Witness - On Rescuing Local Memory of the Holocaust in Poland." East European Politics and Societies and Cultures, 2018, DOI: 10.1177/0888325418798692.

Szacka, Barbara. Czas przeszły, pamięć, mit. Warsaw: Wydawnictwo Naukowe Scholar, 2006.

Szacki, Jerzy. Tradycja. Warsaw: WUW, 2011.

Szarek, Jarosław and Mateusz Szpytma. Ofiara Sprawiedliwych. Rodzina Ulmów - oddali życie za ratowanie Żydów. Kraków: Dom Wydawniczy "Rafael”, 2004.

Szarek, Jarosław and Mateusz Szpytma. Sprawiedliwi wśród Narodów Świata. Przejmująca historia polskiej rodziny, która poświęciła swoje życie, ratując Żydów. Kraków: Dom Wydawniczy “Rafael”, 2007. 
Szarek, Jarosław and Mateusz Szpytma. Rodzina Ulmów. Przejmująca historia polskiej rodziny, która poświęciła swoje życie ratując Żydów. Kraków: Dom Wydawniczy "Rafael”, 2014.

Szarek, Jarosław and Mateusz Szpytma. Rodzina Ulmów. Przejmująca historia polskiej rodziny, która poświęciła swoje życie ratując Żydów. Kraków: Dom Wydawniczy "Rafael”, 2016.

Szarota, Tomasz. "Mord w Jedwabnem. Dokumenty, publikacje i interpretacje z lat 1941-2000. Kalendarium.” In: Wokół Jedwabnego. Vol. 1. Studia, eds. Paweł Machcewicz and Krzysztof Persak. Warsaw: Instytut Pamięci Narodowej, 2002, pp. 461-488.

Szpociński, Andrzej. "Miejsca Pamięci.” Borussia, Vol. 29, 2003, pp 16-27.

Szpytma, Mateusz. "Stracili życie - uratowali świat. Rozstrzelanie 24 marca 1944 r. Józefa i Wiktorii Ulmów i ich dzieci za ukrywanie Żydów." In: $Z$ przeszłości Żydów polskich. Polityka - Gospodarka - Kultura - Społeczeństwo, eds. Jacek Wijaczka and Grzegorz Miernik. Kraków: Instytut Pamięci Narodowej, 2005, pp. 205-229.

Szpytma, Mateusz. The Risk of Survival. The Rescue of the Jews by the Poles and the Tragic Consequences for the Ulma Family from Markowa. Warsaw: Institute of National Remembrance, 2009.

Szpytma, Mateusz. "Sprawiedliwi i inni.” Więź, Vol. 10, No. 636, 2011, pp. 100-101.

Szpytma, Mateusz. "Zbrodnie na ludności żydowskiej w Markowej w 1942 roku w kontekście postępowań karnych z lat 1949-1954." Zeszyty Historyczne WiN-u, Vol. 40, 2014, pp. 39-66.

Szpytma, Mateusz. Sprawiedliwi i ich świat. Markowa w fotografii Józefa Ulmy. Warsaw: Instytut Pamięci Narodowej - Komisja Ścigania Zbrodni Przeciwko Narodowi Polskiemu; Kraków: Instytut Studiów Strategicznych, 2015.

Sztompka, Piotr. Trauma Wielkiej zmiany. Społeczne koszty transformacji. Warsaw: Instytut Studiów Politycznych PAN, 2000.

Szulikowska, Maria. Markowskie bociany: opowieść o bohaterskiej rodzinie Wiktorii i Józefa Ulmów. Przemyśl: Wydawnictwo Archidiecezji Przemyskiej, 2017.

Szylar, Tadeusz. "Markowa wieś spółdzielcza." In: $Z$ dziejów wsi Markowa, ed. Janusz Półćwiartek. Rzeszów: Towarzystwo Przyjaciół Markowej, 1993, pp. 211-241.

Szymańska, Sylwia and Andrzej Żbikowski. "Relacje ocalałych Żydów o losach ludności Żydowskiej w Łomżyńskiem i na Białostocczyźnie po 22 czerwca 1941 roku." In: Wokół Jedwabnego. Tom 2. Dokumenty, eds. Paweł 
Machcewicz and Krzysztof Persak. Warsaw: Instytut Pamięci Narodowej, 2002, pp. 179-374.

Taborska, Halina. Miasto, które nie zginęło. Ludność cywilna Warszawy 19391945 i pomniki jej poświęcone. Warsaw: Bellona, 2014.

Tarczyński, Marek. Cud nad Wisła. Bitwa Warszawska 1920. Warsaw: Instytut Wydawniczy Związków Zawodowych, 1990.

Tokarska-Bakir, Joanna. "Dalsze losy syna marnotrawnego: projekt etnografii nieprzezroczystej”. Konteksty: Polska Sztuka Ludowa, Vol. 1, 1995, pp. 13-22.

Tokarska-Bakir, Joanna. Rzeczy mgliste. Sejny: Fundacja Pogranicze, 2004.

Tokarska-Bakir, Joanna. Okrzyki pogromowe. Szkice z antropologii historycznej Polski lat 1939-1946. Wołowiec: Wydawnictwo Czarne, 2012.

Tomasz, Rakowski, “Etnografia, pamieć, eksperyment: w stronę alternatywnej historii społecznej." Teksty Drugie, Vol. 6, 2016, pp. 268-281.

Tomicki, Ryszard. "Kultura-Dziedzictwo-Tradycja." In: Etnografia Polski: przemiany kultury ludowej, Vol. 2, ed. Maria Biernacka et al. Wrocław: Ossolineum, 1981, pp. 353-370.

Törnquist-Plewa, Barbara. "The Jedwabne Killings - A Challenge for Polish Collective Memory." In: Echoes of the Holocaust. Historical Cultures in Contemporary Europe, eds. Klas-Görnan Karlsson and Ulf Zander. Lund: Nordic Academy Press, 2003, pp. 141-177.

Tschuggnall, Karoline and Harald Welzer, "Rewriting Memories: Family Recollections of the National Socialist Past in Germany." Culture \& Psychology, Vol. 8, No. 1, pp. 130-145.

Tuan, Yi-Fu. Space and Place: The Perspective of Experience. Minneapolis: University of Minnesota Press, 2001.

Urbaniak, Jakub. "Religion as Memory: How Has the Continuity of Tradition Produced Collective Meanings? - Part One." Theological Studies, Vol. 71, No. 3, 2015, pp. 1-8.

Urynowicz, Marcin. "Ludność żydowska w Jedwabnem. Zmiany demograficzne od końca XIX wieku do 1941 roku na tle regionu łomżyńskiego." In: Wokół Jedwabnego. Tom 1. Studia, eds. Paweł Machcewicz and Krzysztof Persak. Warsaw: Instytut Pamięci Narodowej, 2002, pp. 83-104.

van der Merwe, Chris N. "Rethinking Religion in a Time of Trauma." In: Trauma, Memory, and Narrative in the Contemporary South African Novel: Essays, eds. Ewald Mengel and Michela Borzaga. Amsderdam and New York: Rodopi, pp. 195-215.

Vansina, Jan. Oral Tradition as History. Madison: University of Wisconsin Press, 1985. 
Walicki, Andrzej. Filozofia polskiego romantyzmu. Kraków: Universitas, 2009.

Walzer, Michael. Spheres of Justice: A Defense of Pluralism and Equality. New York: Basic Books Publishers, 1983.

Wawrzeszczak, Zbigniew. “Józef Ulma (1900-1944).” In: Z dziejów wsi Markowa, ed. Janusz Półćwiartek. Rzeszów: Towarzystwo Przyjaciół Markowej, 1993, pp. 461.

Wawrzyniak, Joanna. Veterans, Victims, and Memory. The Politics of the Second World War in Communist Poland. Translated by Simon Lewis. Frankfurt a.M.: Peter Lang, 2015.

Wierzbieniec, Wacław. Wielki Strajk Chłopski w 1937 roku. Uwarunkowania $i$ konsekwencje. Rzeszów: Wydawnictwo Uniwersytetu Rzeszowskiego, 2008.

Wierzbicki, Marek. "Stosunki polsko-żydowskie na Zachodniej Białorusi w latach 1939-1941.” In: Wokót Jedwabnego. Tom 1. Studia, eds. Paweł Machcewicz and Krzysztof Persak. Warsaw: Instytut Pamięci Narodowej, 2002, pp. 129-158.

Winter, Jay. Remembering War: The Great War between Memory and History in the Twentieth Century. New Haven: Yale University Press, 2006.

Winter, Jay. "Sites of Memory and the Shadow of War." In: Cultural Memory Studies: An International and Interdisciplinary Handbook, eds. Astrid Erll, Ansgar Nünning, in collaboration with Sara B. Young. Berlin/New York: de Gruyter, 2008, pp. 61-73.

Wolentarska-Ochman, Ewa. "Collective Remembrance in Jedwabne. Unsettled Memory of World War II in Postcommunist Poland." History and Memory, Vol. 18, No. 1, 2006, pp. 152-178.

Wolny, Helena. "Pieśń ludowa epicka jako obraz i utrwalenie wydarzeń autentycznych o martyrologii wsi polskiej w latach 1939-1945." In: Druga wojna światowa w literaturze polskiej i obcej, ed. Lech Ludorowski. Lublin: Wydawnictwo UMCS, 1992, pp. 117-141.

Wóycicka, Zofia. Arrested Mourning. Memory of Nazi Camps in Poland, 19441950. Frankfurt am Main: Peter Lang, 2013.

Wóycicka, Zofia. "Global Patterns, Local Interpretations: New Polish Museums Dedicated to the Rescue of Jews during the Holocaust." Holocaust Studies: A Journal of Culture and History, Special Issue: Disputed Holocaust Memory in Poland (upcoming).

Wroniszewski, Danuta and Aleksander. “...aby żyć,” Kontakty (Łomżyński Tygodnik Społeczny, Pismo PZPR). Vol. 27, No. 403, 1988, pp. 1-9.

Wylegała, Anna. „Krajobraz po wojnie: anatomia rozpdu świata społecznego na przykładzie Polski w okresie II wojny światowej." Studia Socjologiczne, 3, 2016, pp. 133-163. 
Zalewska, Joanna. Człowiek stary wobec zmiany kulturowej. Warsaw: Wydawnictwo Scholar, 2015.

Zalewska, Joanna. „Consumer revolution in People's Poland: Technologies in everyday life and the negotiation between custom and fashion (1945-1980)." Journal of Consumer Culture, 17(2), 2017, pp. 321-339.

Zaremba, Marcin. Komunizm, legitymizacja, nacjonalizm. Nacjonalistyczna legitymizacja władzy w komunistycznej Polsce. Warsaw: Wydawnictwo Trio, 2001.

Zaremba, Marcin. Wielka trwoga: Polska 1944-1947: Ludowa reakcja na kryzys. Kraków: Wydawnictwo Znak: Instytut Studiów Politycznych Polskiej Akademii Nauk, 2012.

Zieliński, Jan. ““5 Minutes, 94 Years and Much Longer” (Jerzy Giedroyc, 19062000)." Studies in East European Thought, Vol. 52, 2000, pp. 327-331.

Ziembiński, Wojciech. “Pomnik Ofiar Agresji Sowieckiej 17 IX 1939.” In: Warszawa o czym mówia pomniki i kamienie, eds. Karol Mórawski and Andrzej Stwarza. Warsaw: Muzeum Niepodległości, 2000, pp. 260-263.

Zmijewski, Norbert. "Vicissitudes of Political Realism in Poland: Tygodnik Powszechny and Znak." Soviet Studies, Vol. 43, No. 1, 1991, pp. 83-106.

Zowczak, Magdalena. Biblia ludowa. Interpretacje wątków biblijnych w kulturze ludowej. Wrocław: Funna (Monografie Fundacji na rzecz Nauki Polskiej), 2000.

Zubrzycki, Geneviève. The Crosses of Auschwitz: Nationalism and Religion in Post-Communist Poland. Chicago: The University of Chicago Press, 2006.

Zwolski, Marcin. Śladami zbrodni okresu stalinowskiego w województwie białostockim. Białystok: IPN Bialystok, 2013.

Żaryn, Jan. "Polacy ratujący Żydów w świetle nowych źródeł." In: Polacy ratujacy Żydów. Historie niezwykłe, eds. Jan Żaryn and Tomasz Sudoł. Warsaw: Wydawnictwo Neriton, 2014, pp. 11-94.

Żbikowski, Andrzej. "Pogromy i mordy ludności żydowskiej w Łomżynskiem i na Białostocczyźnie latem 1941 roku w świetle relacji ocalałych Żydów i dokumentów sądowych.” In: Wokół Jedwabnego. Tom 1. Studia, eds. Paweł Machcewicz and Krzysztof Persak. Warsaw: Instytut Pamięci Narodowej, 2002, pp. 159-271.

Żukowski, Tomasz. "Sprawiedliwi - sposób dyskryminacji Żydów." Przekrój. 8 Oct. 2008, pp. 20-22.

Żychlińska, Monika. "Muzeum Powstania Warszawskiego jako wehikuł polskiej pamięci zbiorowej." Kultura i Społeczeństwo, Vol. 53, No. 3, 2009, pp. 89-113. 



\section{Note on Authors}

Zuzanna Bogumił is an assistant professor at the Maria Grzegorzewska University in Warsaw. Her research to date has dealt with religious conflicts in Ukraine and Russian memory of twentieth-century Soviet repressions, as well as the symbolic meanings of historical exhibitions in Central and Eastern Europe. Her recent books include: Gulag Memories: The Rediscovery and Commemoration of Russia's Repressive Past (Berghahn Books 2018), The Enemy on Display: The Second World War in Eastern European Museums (co-author, Berghahn Books 2015), and Stare i nowe tendencje w obszarze pamięci społecznej [(Old and New Tendencies in Social Memory)] (co-editor, Scholar 2018).

Małgorzata Głowacka-Grajper is a sociologist, social anthropologist, and assistant professor at the Institute of Sociology, University of Warsaw. Her research interests include: social memory, ethnic tradition, contemporary developments in ethnic identity, and minority group activism. Her current research projects concern the relation between memory and religion and the class dimension of social memory. She is the author of the book Transmisja pamięci. Działacze sfery pamięci i przekaz o Kresach Wschodnich we wspótczesnej Polsce [The Transmission of Memory. Memory Activists and Narratives of Former Eastern Borderlands in Contemporary Poland] (Wydawnictwo Uniwersytetu Warszawskiego 2016). 



\section{Index}

Terms that occur extremely often, like church, commemoration, community, cross, death, Germans, local community, memory, Poles, suffering, and victim are not included in this index.

A

Alexander, Jeffrey 31, 32, 127, 155, 263, 268

All Souls' Day 102, 159, 167, 184

anti-Semitic see anti-Semitism

anti-Semitism 127, 148, 155,

180, 245

Arnold, Agnieszka see also Neighbors film 142, 149-155

Assmann, Aleida 30, 31, 34, 263, 271

August, Decree 134

Auschwitz 28, 29, 35, 37, 40, 47, 67, $87,89,92,125,160,247,270,281$

Azavedo, Carlos 225

B

Baczyński, Andrzej 238

Balkans 160

Bar (family) 195, 212

Baranek (family) 241, 242

Bardoń, Karol 135

Bełżec 193

Berlin 18, 28, 38, 111, 119, 160, 233, 263, 265, 270, 271, 277, 280

Bezirk Bialystok 25

Będzin 68

Białoboki 192

Białystok 25, 41-43, 129, 132-134, $136,139,142,143,146,172,173$, $182,183,265,274,281$

Biebrza (river) 132

Biernacka, Marianna 22, 156, 279

Biergielski, Adam 156
Bierut, Bolesław 93, 135

Bikont, Anna 130-133, 137, 140, 142, 155, 156, 161, 179, 264

Birkner, Wolfgang 139

Blue Police 194, 197

Bodzentyn 68, 88

Bolsheviks 78, 79

Böttcher, Herbert 95

Brandt, Willy 192, 239, 269

Brody 83

Bug (river) 24

Butler Breese, Elizabeth 31, 32, 263, 268

Bydgoszcz 40, 68

C

Camp of Great Poland 130

Can Ozan 35, 264

Casanova, José 33-35, 265

Catholicism 26, 35, 179, 235, 273

Catholic Church 23, 34, 35, 40, 49, $53,70,77,79,84,130,138,142$, $179,188,191,212,214,215,225$, 243, 246, 247, 248, 253-255, 257

Center for Holocaust Research 234, 239, 240, 244

Chajewski, Michał 161

Chodak, Zbigniew 97, 140, 265

Chodakiewicz, Marek Jan 140, 265

Ciepielewska, Wanda 61

Civic Platform 45

Coelho, Joao Pinto 180, 265

Commission for the Investigation of Nazi Crimes 36, 54, 95, 96, 136, 146 
Commission for the Prosecution of Crimes against the Polish Nation 36, 101, 102, 146, 189

Committee to Protect the Good Name of the Town of Jedwabne 155,159

Communist 19, 25, 28, 29, 33, 35-37, 39, 41, 45, 57, 66, 70, 72, 73, 82, 94, 96-98, 108, 127, 135, $143,144,149,156,165,214,234$, $247,254,270,280,281$

Congregation for the Causes of Saints 213, 215

Council for the Protection of Struggle and Martyrdom Sites 13, $38,45,57$

Council to Aid Jews see Żegota

Cross of Grunwald 96

Czech 87, 198

Częstochowa 69, 157, 273

D

Dachau 156, 160, 247

Daniels, Jonny see also Depths Foundation 184

Daniłowicz Potocka, Marianna 249

Datner, Szymon 143, 235, 242, 266

Davis, Norman 23, 24, 26, 242, 266, 268

Dąbrowa, Stefan 90, 104

Deportation 131, 132, 141, 170, 173,174

Depths Foundation see also Daniels, Jonny 184, 185

Dębicki, Ewaryst 200

Didner, Leah (Layta) 196

Dieken, Eilert 197

Diocese of Pelplin 213

Diocese of Przemyśl 213

Directorate of Civil Resistance 25

Directorate of Sabotage (Kedyw) 88

District of Galicia 24

Dmowski, Roman 130
Doły Biskupie 54, 55, 60

Domagalski, Alfred 98

Duda, Andrzej 189, 226, 247

Dudziewicz, Michał 238

Dziedzic, Janusz 22, 151, 155, 279

E

Einhorn, Jakub 207

Engelking, Barbara 194, 195, 206, 207, 236, 239, 240, 266, 267, 275

environments of memory see milieux de mémoire 16 episteme 250

Etkind, Alexander 28, 71, 155, 156, 173, 267

European Solidarity Center 43, 45

Exhumation 115, 182-185

F

Falkiewicz, Krzysztof 102

Feliński Szczęsny, Zygmunt 70

Finkelstein, Rachel 133

First Polish Republic 23

First Suchedniów Scouting Troop 91

First World War 19, 20, 97, 171, 188

Forecki, Piotr 28, 38, 127, 171, 189, 200, 245, 267, 270, 271

Forest of Crosses 99, 113, 116, 126

Foucault, Michel 250, 267

Foundation for Polish-German Reconciliation 98, 101

France 25, 87, 121, 264

Francis of Assisi St. 143

Frank, Hans 24, 192

Freedom and Independence 13, 38, 70

Frelichowski, Stefan 246, 247

G

Gać (village) 187, 188, 265

Galicia, see also District of Galicia 20, 187 
Gapys, Jerzy 97

Gazeta Wyborcza 151, 178, 179, 191, 197, 220, 232, 234, 236, 237, 240, 241

Gądecki, Stanisław 221

Gdańsk 35, 37, 39, 97, 168, 186, 240

Gdańsk Agreement 35

General Government 20, 21, 116, 128,233

Gestapo 85, 132, 144

Getter, Matylda 237, 238

Gębice 49-51, 53-58, 64, 68, 78, 247, 255

Gębski, Józef 94

Ghetto 21, 22, 129, 139, 184, 209, 230, 233, 235

Giedroyc, Jerzy Władysław 231, 277

Gliński, Piotr 244

Gmitruk, Janusz 48, 73-77, 81, 83, $88,90,94,97,262,263$

Godlewski, Krzysztof 133, 151, 157

Goldman, Chaim 192, 218

Goldman, Saul 192, 228

Golgotha 37, 42, 47-49, 64-73, $75,77,79,80,81,95,109,157$, 168,255

Golgotha of the Polish Nation 47, $48,64,70-73,75,79,255$

Gostomski, Henryk 92

Górny, Grzegorz 238, 264

Górski, Roman 142

Grabarka 109

Grabińska, Maria 92

Grabowski, Jan 140, 185, 189, 190, 191, 194, 197, 202, 203, 232, 240, $241,242,249,262-264,271$

Graff, Agnieszka 236, 237

Grand History 61, 164, 174

Gray, Ranks 87

Grądowski, Izrael see Józef Grądowski

Grądowski, Józef 129, 142, 143

Great Peasant Uprising 75, 76
Greece 83

Grodzisko, Dolne 209

Gross, Jan Tomasz see also Neighbors book 123, 129, 133, 135, 136, 148, $149,151,161,166,176,178,225$, $248,249,261,269$

Gross-Rosen 225

Grünfeld, Genia (Golda) 193

Grzegorczyk, Rozalia and Wojciech 88, 91

Grzymała, Antoni 143

Gwardia Ludowa (People's

Guard) 21, 50, 84, 104

\section{H}

Halbwachs, Maurice 81, 157-159, 174,264

Hein, Julian 91, 264

Heroe 37, 205, 235

Hervieu-Léger, Danièle 29, 30, 264

Hirsch, Marianne 177, 265

historical policy $17,26,27,39,41$, $46,78,80,81,98,99,101,103$, $105,107,109,111,113,187,196$, 203, 230, 240, 241, 249, 253

Holocaust 14, 15, 22, 25, 26, 32, 40, $120,121,123,124,126,130,148$, 176-178, 183, 185, 186, 190, 191, 196, 197, 204, 205, 224, 225, 229-233, 235, 236-241, 250, 253, 264, 265, 269, 272, 273, 275, 276

Holy Cross Mountain 53, 62, 64, 73, 105, 109

Holy Cross Voivodeship (region) 47, 51, 58, 60, 66, 77, 83, 96

Home Army 21, 22, 24, 35, 37, 53, $61,62,64,66,84,88,90,94,95$, $104,105,128,129,142,161,230$

I

Identity $15,16,18,24-26,28,33$, $40,45,66,69,70,72,79,105$, 
$110,115,124,134,149,158,161$, $173,200,228,233,244,248,252$, 263, 279

Ignatiew, Radosław 133

Ilża 50

Institut für Deutsche Ostarbeit 9, 188,265

Institute of National

Remembrance 9, 32, 41, 97, 124, $133,134,136,183,185,188,204$, 218, 223, 233, 234, 235, 240, 274

International War Tribunal in

Nuremburg 83

Iwonicz-Zdrój 65

J

Jagiełła-Niechciałki (cemetery) 194 Janczewko 128

Janicka, Elżbieta 232, 235, 236, 237, 265

Jankowski, Andrzej 49, 50, 85, 91, $92,262,265$

January Uprising 125,158

Jasna Góra 65, 81

Jaworski, Kazimierz 220

John Paul II 40, 76, 97, 152, 242,

$243,244,273$

Jedwabne $16,35,36,42,44,45$, 123-181, 203, 229, 233, 236, 239, 246-250, 252, 253, 256, 260, 261, $263,264-277$

Jedwabnians 125, 136-138, 141, 144-146, 149-157, 160, 162-167, $169,173-177,179,181$

Jedynak, Katarzyna 97

Jewish Historical

Commission 129, 139

Jewish Historical Institute 129, 133, 204, 205, 231

Jewish population see Jews Jews 21, 22, 39-41, 45, 66, 96, 97, 120-148, 154-157, 161, 163-166,
$170,172,174,176,177,178,180$, 183-186, 188-199, 201-203, 205-209, 212, 215, 216, 218-225, 228-239, 241, 243, 245, 247, 250, 253, 256, 257, 260, 261, 264, 271, $274,276,277$

K

Kaczanowski, Longin 51, 83-90, 92, 94, 95, 104, 263, 265

Kaczyński, Lech 234, 237, 238

Kalinowski, Jarosław 95

Kalwaria, Zebrzydowska 81

Kałków-Godów 16, 42, 44, 45, 47-54, 56-68, 70-81, 255, 272

Karolak, Marian 128, 131, 140, 149

Katyn

- Katyn Families 37, 38

- Katyn Massacre 24, 35, 87

- Katyn Museum 38

Kazakhstan 127, 169

Kątnik, Anna 219

Kielce 48-51, 73, 84, 85, 91-97, 104, 262, 265, 266, 269

Kielar, Teofil 194

Kobielno 128

Kokott, Joseph 194

Kolbe, Maximilian Maria 63, 66, 242, 243

Kołodziejczyk, Marcin 177, 178

Kołomańska, Ewa 92, 95, 97, 266

Komorowski, Bronisław 238

Kossak, Zofia 237, 238

Kowalczyk, Józef 73, 208, 219, 271

Kowalski (family) 237

Krajewski, Kazimierz 97

Kraków 15, 17, 20, 26, 29, 39, 43, 53, $81,84,85,94,98,153,187,188$, 192, 193, 195, 196, 203, 231, 234, $239,259,262,266-269,272-274$, 276, 277

Krogulec Hipolit 90 
Krynki 50-52, 54-58, 68, 78, 247, 255

Kucze Wielkie 177, 178

Kunów 50, 79

Kupiecki, Czesław 132

Kura, Antoni 97

Kurek, Ewa 136, 178-180, 266

Kurkowska-Budzan, Marta 43, 138, 139, 145-151, 154, 160, 162-166, $177,239,266$

Kurtyka, Janusz 220, 234

Kwaśniewski, Aleksander 95, 123, 124, 150, 166, 233

Kwiecień, Józef 60

L

late modernity $17,26,29$

Laudański brothers see also Laudański Jerzy 128, 142

Laudański Jerzy see also Laudański brothers 131

Law and Justice party 40,41, 157, 166,242

Leja, Stanisław 208, 209, 211, 212, 220, 248

Lenin monument 134

Leś, Włodzimierz 193

Libionka, Dariusz 126-128, 134, 185, 189-191, 197, 202, 203, 230, $240,241,263,264,267$

Licheń 63,81

Lidice 83

lieu de mémoire, see site of memory

Lim, Jie-Hyun 31, 33

Lindwer, Willy 237

London 22, 25, 33, 92, 130, 139, 255, 257, 265, 266, 276, 277

Lubańska, Magdalena 17, 22, 32, 255, 271

Lublin $37,91,140,159,167$, 182-185, 214, 237, 249, 263, 270, 273-275, 280
Łagiewniki 85

Łańcut 189, 194, 196-198, 209, 213, 225

Łojewski, Franciszek 146

Łomża 129, 130, 133, 135-137, $142,144,145,147,154,156,159$, 177-179, 254, 270

Łomża County see Łomża

Łódź 44, 95, 127, 143, 183, 194, 212, $223,265,266,272,277$

Łuczewski, Michał 21, 22, 30, 31, 207, 243, 257, 271, 272

M

Machcewicz, Paweł 129-132, 134$136,138,139,142,143,145,146$, $271,272,274-281$

Majdanek 35, 37, 92

Majewska, Helena 209

Malinowski, Roman 80, 97, 103

Mańko, Ewa 169

March 1968 148, 149

March of Living Memory 172

Marczewski, Katarzyna and Maciek 51, 52, 73

Markowa 20, 43, 46, 48, 50, 101, 187-234, 236, 238, 240, 242, 244-246, 248, 250-257, 260, 261, 264, 266, 268, 269, 275, 278, 280

Markowski, Rafał 179, 180, 244, 245, 278

Marschall, Sabine 16-18, 272

martyrdom $13,33,36,38,43,45$, $55,57,67,69,71,73,75,81,83$, $87,93,96,97,100,109,116,125$, $149,150,156,202,208,215,216$, $218,219,239,260$

mass execution $25,31,88,137$, 151, 198

mass killings see mass execution mass media 19, 28, 56, 136, 137, $143,146,149,160,179,193,198$ 
mass murder see mass execution

Materek (family) 117

Materek, Władysław see also Materek (family) 89

Mausoleum of the Martyrdom of Polish Villages $81,87,93,96,97$, $100,109,125,260$

Messianism 33, 34, 266

Michalik, Józef 217, 223, 225

Michniów 20, 39, 43, 46, 48, 49, 81-83, 87-126, 204, 228, 250, 251, $254,255,257,259,260,267,270$

Mickiewicz, Adam 35

Miernik, Ryszard 95, 96, 118, 192, 272, 278

Migdał, Całka 134

Mikołajczyk, Stanisław 80

milieux de mémoire, see also environments of memory;

vernacular 7, 15, 16, 21, 22, 46, 47

Ministry of Culture and National

Heritage 100, 248

Misztal, Henryk 214, 273

Mithander, Conny 29, 273

Monkiewicz, Waldemar 136

Montevideo 134

monument

- in Jedwabne see also

Jedwabne 129, 157, 163-165

- in Markowa 221-223, 261

- to Martyrs of the Communist

Terror 1944-1956 41

- to the Heroes of the Warsaw

Uprising 41, 176

monument therapy $129,156,170$, 174,184

moral capital $21,30,31,43,81$, 243, 257

moral narrative $29,31,33$

Morawiecki, Mateusz 189, 247

Morawski, Adolf 92

Moscow 33, 34, 160
Mother of God 61, 77

Motor, see Jerzy Wojnowski

Mount Tabor 160

Mrozowicz, Kamil 181, 182

Mróz, Lech 18, 273

Muranów 44, 239

museum

- Historical Museum of the City of Kraków 43

- Museum of Polish History 43

- Museum of the Martyrdom of Polish Villages 43, 96, 97, 100

- Museum of the Second World War 43, 190, 244

- Museum of the Siberian Deportee 43

- Oskar Schindler's Enamel Factory Museum 43

- POLIN Museum of the History of Polish Jews 43, 45, 240

- Polish Army Museum 42

- Ulma Family Museum of Poles Saving Jews during Second World War

- See also Katyn Museum; Warsaw Uprising Museum 13, 43, 101, 188, 190, 213, 224, 229

$\mathbf{N}$

narrative $16,19-23,28-33,42$, $43,46,48,56,62,64,66-69,71$, 73-77, 80-82, 84, 85, 87, 88, $102-109,123,125,126,152$, $156,158,178,189,190,205,208$, $210,211,218,228,231,232,234$, $241,245,246,252-256,263,265$, 279, 283

nation $20,21,28,30,31,35,40,41$, $45,51-53,64,66,68,71-75,77$, $79,81-85,101,102,119,134,149$, $150,154,155,160,161,176,179$, $180,190,193,199,203,208,212$, 
$219,220,228,233,236,239,240$, 246, 247, 257, 259, 263

National Armed Forces 13, $25,42,70$

National Democracy $13,96,130$

national history $19,20,44,64,67$, $76,80,82-84,106$

National Independence Day

(11 November) 61

National Rebirth of Poland Day 96, 164

Nationalism see also victimhood nationalism 28, 31, 33, 34, 130, 243, 271, 281

Nawojski, Edward 197

Nawrocki, Karol 190

Navahrudak 66, 98, 247

Nazi 15, 18, 25, 35, 36, 38, 39, 45, 54-60, 87, 95, 96, 98, 109, 134, $136,143,146,151,156,160,165$, $166,198,206,207,235,238,259$, 260, 280

Neighbors

- book see also Jan Tomasz Gross 127, 133, 153, 165, 252

- film see also Agnieszka Arnold 142, 149, 151, 155

New York 22-25, 28-30, 32, 38, $130,181,190,233,250,255,257$, 263-271, 273, 274, 276, 277, 279, 280

Niemczak, Stanisław 196, 204, 205, 207

Niemczak, Urszula 206

Niepokalanów 81

Nizio International Design 96, 120, 226

Niziołek, Maria 236, 237, 269

Niziurski, Mirosław 91 non-lieux de memoire, see also non-site of memory 13, 272 non-site of memory 13
Nora, Pierre 11, 12, 18, 150, 157, 269

Nowak, Jerzy Robert 136, 269

O

obelisk 27, 163

Olszewo 158, 159, 256

Operation Reinhardt see Reinhardt Operation

Orchard of Remembrance 217, 222, 224, 226, 257

Ordnungspolizei 85

Orlikowo 158, 159, 256

Oświęcim, see Auschwitz

Our Holy Cross Lady of Sorrows Sanctuary 36, 47, 48, 58, 63, 64, 74, 255

$\mathbf{P}$

pacification $44,49-57,59-61,64$, 68, 78-81, 85-95, 97-102, 105, $108,112-118,120,121,122,247$, 248, 255

Pająk, Leon 92, 93

Pałyga, Jan 65, 270

Pantheon of Polish Peasants 74-77, 81, 255

Papierniak, Henryk 91

Paprocki, Bogusław 51, 265

Parish

- community 63, 153-155, 157, $158,170,174$

- cemetery 51, 54, 56, 57, 68, 78, $152,170,171$

- church 14, 16, 49, 52, 56-58, 152, 196, 214, 221, 237, 248, 250, 256

Parliament of the Republic of Poland 41

partisan $49,50,53,61,62,64,84-88$, $90,94,95,100-105,112,116,120$, 128, 129, 140, 203, 243

Pawlak, Waldemar 95, 96, 245, 270 
Pawłoś, Dariusz 97

Pawłów 47, 64, 79

peasant

- Peasant Action Day 74-76, 81, 95, 202

- Peasant Battalions 21, 64, 104

People's Party $66,73,75,77,78,80$, 94-96, 105, 249

perpetrator $26,27,91,97,98,133$, 134, 140, 144, 176

Persak, Krzysztof 125-135, 138-144, 232, 267, 268, 270-272, 274-277

Peszkowski, Zdzisław 37

Peters, Florian 223, 232, 271

Piaszczyński, Michał 152

Piątkowski, Władysław 202

Pieta Michniowska (Michniów

Pieta) 93, 94, 112, 256

Pieta, see also Pieta

Michniowska 57, 58, 64, 95, 113, 255

Piłsudski, Józef 74, 75, 269

Piwnik, Jan (Ponury) 84, 85

Podkarpackie Voivodeship see Subcarpathian

Podlaskie Voivodeship 125, 169

Polish Council of State 26, 96

Polish People's Party 13, 70, 77, 81, 82, 84, 98-100, 109, 253

Polish People's Republic 13, 27, 37, $45,79,100,108,147,148,154$, 163, 207, 234, 270

Polish Tourist and Sightseeing Society 13, 96

Polish Underground State 25, 134, 187, 197, 234, 242, 248

Polish Workers' Party 25

Pol, Wincenty 92

Ponury see Jan Piwnik

Popiełuszko, Jerzy 7, 8, 40, 43, 44, 70, 74, 156, 244, 246, 264
Powązki 40

Półćwiartek, Janusz 191, 192, 196, 204, 205, 208, 266, 275, 278, 280 prisoners-of-war 109, 132, 134, 198 Pruszków 15

Q

Queen of Poland 57, 61, 83

$\mathbf{R}$

Radio Maryja 246, 247

Radom 57, 77, 89, 95, 276

Radziłów 130, 132

Radzymin 7, 39, 69, 267

Ramotowski, Bolesław 146

Ramotowski, Józef Konstanty 162, 163,260

Ramotowski, Stanisław 133

Rataj, Maciej 68, 80

Rataje 68

Recovered Territories 147

Red Army 25, 26, 131, 132, 195, 196, 198, 201

Reguły 15, 19, 257, 273

Reinhardt Operation 25, 26, 237

Religiosity 113, 157, 159, 178, 179

Rembieliński family 153

Ribbentrop-Molotov Pact 24

Righteous Among the Nations

- see also museum/ Ulma Family Museum of Poles Saving Jews in World War II 70, 133, 188, 190, 199, 208, 209, 212, 219, 220, 228, 233, 237, 238, 240, 252, 257, 263

ritual $15,16,18,23,62,83,119,129$, $157,159,164,176,180,184,201$, 217, 249-252, 256

Roma see also Sinti 18, 88, 198

Roman Catholic religion, see also

Catholicism 18, 26, 33, 35, 112, 264

Romanov (family) 214 
Rudnik nad Sanem 62

Russian Orthodox Church 214, 255

Rwanda 160

Rydzyk, Tadeusz 246

Ryszka, Czesław 56, 57, 67-71, 75, 77, 276

Rzepin 65

Rzeszów 79, 189, 191, 192, 196, 198, 204-206, 208, 223, 223, 227, 228, $266,267,275,278,280$

\section{$S$}

Sachsenhausen (Oranienburg) 156 sanctuary

- Sanctuary of the Martyred Polish Brothers 40

- Sanctuary to the Fallen and Murdered in the East 40, 41

- See also Our Holy Cross Lady of Sorrows Sanctuary

Schudrich, Michael 183, 225

scout 90-92, 169, 176, 177, 205, 247

Second Polish Republic 24, 79, 100

Second World War 13, 18-20, $23-30,35,37,38,43,45,48,53$, $55,57,59,61,63,65-67,70,72$, 84, 87-89, 92, 95, 97-101, 109, 124-127, 129, 131, 133, 135, 137, $138,147,150,160,169,172,188$, 190, 192, 193, 198, 202, 212-214, $224,229,233,238,242,244,245$, 247, 248, 264, 277, 280, 283

Secular 17, 19, 20, 31, 33, 34, 37, 44, $64,69,83,111,112,143,161,172$, $179,218,219,221,223,232,246$, 253-255, 265, 271

Segal, Abrahan 223

Sellin, Jarosław 190

Sendler, Irena 234, 238, 239, 241, 242

Sendyka, Roma 17, 159, 276 servants of God

- The Ulma Family Servants of God School 50, 188, 211, 216-218, 223, 229, 233, 238

Sędziak, Zdzisław 137, 276

shrine $15,16,35,37,39,67,76,157$, $162,167,174,249,250$

Siberia 41-43, 131, 141, 156, 165, 170, 173

Sicherheitspolizei 13,89

Siemaszko, Ewa 101

Sieradowice 88

sierpniówki see August Decree

Sinti see also Roma 18

site of memory $15-18,20,23$, $35,36,38-40,45,47,53,58$, $66,68,77,79,81-84,92,94$, $99,113,119,125,143,149,150$, $166,168,170,171,173,174,176$, $184,222,229,239,248,250,253$, 254, 280

Smolensk 70, 71

Sobuta, Józef 135, 146

Society of Fighters for Freedom and Democracy 13, 96, 136

Society of Friends of Markowa 204, 205, 208, 220, 231

Sokołowska, Julia 145, 148

Solidarity Independent SelfGoverning Labor Union see Solidarity

Solidarity $39,40,43,45,70,79$, 80,171

Soviet occupation 92, 131, 132, 136, 138, 157

Starachowice $51,60,61,81,83$

Stations of the Cross 75, 139, 177, 217

Stawarz, Wincenty 77, 80, 268

Stawicki, Wacław 98

Stefanek, Stanisław 159, 160, 161, 160, 180, 277 
Steinfeldt, Irena 233

Stockholm Declaration 128

Strzembosz, Tomasz 140, 253, 277

Styków 54

Subcarpathian 62, 187, 189, 206, $225,228,245$

Suchedniów 88, 91, 98, 118

Sułek, Antoni 18, 277

Sundholm, John 29, 30, 273

Surowiecki, Antoni 147

Sybiraks

- Sybiraks Memorial see also Jedwabne 166, 170-174, 176, 177,260

Szacki, Jerzy 22, 34, 277

Szal, Adam 213

Szalls (family) 196, 197

Szarek, Jarosław 192, 196, 199, 224, 232, 238, 277, 278

Szarota, Tomasz 132, 136, 139, 143, 278

Szlaga, Jan Bernard 213

Szpytma, Mateusz 101, 189, 192, 193, 195-199, 206, 207, 211, 224, $227,231,232,238,244-246,252$, 253, 277, 278

Sztompka, Piotr 128, 278

Szubarczyk, Piotr 101

Szulikowska, Maria 208, 209, 244, 245, 278

Szwagrzyk, Krzysztof 184

Szydło, Beata 247

Szylar (family) 212

Szymańska, Sylwia 139, 278

Szymczak, Rafał 240, 241

Śleszyński, Bronisław 132, 135, 138, 147

Świerczewski, Karol 164

Święta, Katarzyna 68

Świętokrzyskie Voivodeship, see Holy Cross Voivodeship
$\mathrm{T}$

Tchorek, Karol 36

Tehran Conference 26

Terlikowski, Tomasz 214

Third Reich 24, 46, 90, 138, 139

Tokarska-Bakir, Joanna 155, 182, 194, 203, 279

Tomb of the Unknown Soldier 41, $157,166,170,172,174,175$, 177,260

Tomicki, Ryszard 22, 279

Torańska, Teresa 239

Toruń 22, 246-248, 271

tradition 15-19, 21, 22, 27, 33-37, $43,45,60,61,64,65,81,85,102$, $114,116,129,154,157-159$, 162-164, 167, 170, 174, 177, 178, 279,283

trauma

- collective trauma 31,32, 250

- cultural trauma 128, 129

Treaty on Borders and

Friendship 24

Treblinka 133

Tuan YiFu 162

Turk Manachem 143

Tygodnik Powszechny 231-235, 281

Tylicz 68

U

Ujazdowski, Kazimierz 238

Ukraine 114, 226, 237, 283

Ukrainian Insurgent Army 13, 99

Ulma family see also museum/ Ulma Family Museum of Poles Saving Jews during Second World War 13, 43, 50, 101, 187-190, 192, 195-205, 207-218, 220-227, 229-232, 236, 238, 242, 244, 245, $251,254,255,257,260,261,268$, 275, 278

Ulmas see Ulma family 
Ulma, Józef see also Ulma family $192,196,197,202,205$, 208, 209, 216, 222, 227, 228, 231, $232,278,280$

Ulma Wiktoria see also Ulma family $197,200,208-211,216$, 222, 227, 231, 232

Union of Armed Struggle 25

Union of Soviet Socialist Republics 24

Uruguay 134

Urynowicz, Marcin 129, 130, 143, 279

USSR see Union of Soviet Socialist Republics 13, 24, 46, 131, 138

V

van der Merwe, Chris N. 32, 279

Vatican 213, 225

Velicu, Arien 29, 30, 273

Vernacular see also milieux de mémoire

- vernacular commemoration 16-18, $47,48,55,64$

- vernacular communities $34,37,46$

- vernacular memory $17,18,48,55$, $57,59,61,63,94,126,129,178-181$, $183-185,198,200,251$

victimhood nationalism $31,33,34$, 343, 271

Virgin Mary see also Queen of Poland 15, 67, 69, 79

Virtuti Militari Cross 94

Volhynia 39, 46, 99, 101, 275

Volksliste 193

\section{W}

Wadowice 44

Wala, Czesław 55-57, 61, 66, 67, 70, $75,77,80,81,252,253$

Walusiak, Dariusz 238
Walzer, Michael 30, 280

Warsaw Uprising 25, 28, 39, 41, 76, $176,177,237,264,276$

Warsaw Uprising Museum 42, 43, 52,124

Wasserstein, Shmuel 132-134, 137, $139,143,144$

Wawrzyniak, Joanna $19,28,37,96$, 136, 148, 149, 208, 264, 280

Wąchock 98

Wąsosz 132

Weiss, Shevah 233

Westerplatte 37

Wierczyński, Rafał 244

Wierzbicki, Marek 131, 132, 280

Wikło, Władysław 89

Winter, Jay 23, 119, 280

Witos, Wincenty 77, 78, 80, 81, 82

Wojnowski, Jerzy (Motor) 89

Wojsławice 249, 250

Wola 36

Wolentarska-Ochman, Ewa 127, $152,158,280$

Wolny, Helena 91, 92, 280

Wroniszewski, Danuta and Aleksandra 137, 142, 144, 145, 147, 149, 150, 253, 280

Wujek Coal Mine 70, 76

Wykus 66, 68, 88, 89, 98

Wyrzykowski, Aleksander 144

Wyrzykowska, Antonina 133

Wyrzykowski family 132, 133

Wyrzykowskis see Wyrzykowski family

Wyszyński, Stefan 70, 80, 156, 173

Wzdół Rządowy 114

$\mathbf{Y}$

Yad Vashem $69,129,185,204$, 205, 208, 215, 224, 229, 232, 239, 253, 264

Yalta Conference 22 
Yugoslavia 83

Z

Zalewska, Joanna 23, 277

Zegadło, Adam 92

Zejer, Stanisław 131

Zienkiewicz, Aleksander 243

Zimowski, Zygmunt 73

Zowczak, Magdalena 198, 277

Żaryn, Jan 230, 231, 234, 242, 277
Żbikowski, Andrzej 135, 184, 222, 271, 274, 277

Żegota 22, 183, 184, 230, 234, 235, 238, 266

Żoliborz 40

Żuchowiec 49-54, 56-58, 64, 78, 247, 255

Żydokomuna (Jew

Commune) 126, 137

Żyluk, Feliks 143 


\section{Geschichte - Erinnerung - Politik Studies in History, Memory and Politics}

Herausgegeben von / Edited by Anna Wolff-Powęska \& Piotr Forecki

Bd./Vol. 1 Machteld Venken: Stradding the Iron Curtain? Immigrants, Immigrant Organisations, War Memories. 2011.

Bd./Vol. 2 Anna Wolff-Powęska / Piotr Forecki: Der Holocaust in der polnischen Erinnerungskultur. 2012.

Bd./Vol. 3 Marta Grzechnik: Regional Histories and Historical Regions. The Concept of the Baltic Sea Region in Polish and Swedish Historiographies. 2012.

Bd./Vol. 4 Lutz Niethammer: Memory and History. Essays in Contemporary History. 2012.

Bd./Vol. 5 Piotr Forecki: Reconstructing Memory. The Holocaust in Polish Public Debates. 2013.

Bd./Vol. 6 Marek Słon (ed.): Historical Atlas of Poland in the 2nd Half of the 16th Century. Voivodeships of Cracow, Sandomierz, Lublin, Sieradz, Łęczyca, Rawa, Płock and Mazovia. Volume 1-4. Translated by Agata Staszewska, Editorial Assistance Martha Brożyna. 2014.

Bd./Vol. 7 Maciej Janowski: Birth of the Intelligentsia 1750-1831. A History of the Polish Intelligentsia - Part 1. Edited by Jerzy Jedlicki. Translated by Tristan Korecki. 2014.

Bd./Vol. 8 Jerzy Jedlicki: The Vicious Circle 1832-1864. A History of the Polish Intelligentsia - Part 2. Edited by Jerzy Jedlicki. Translated by Tristan Korecki. 2014.

Bd./Vol. 9 Magdalena Micińska: At the Crossroads 1865-1918. A History of the Polish Intelligentsia - Part 3. Edited by Jerzy Jedlicki. Translated by Tristan Korecki. 2014.

Bd./Vol. 10 Anna Wolff-Powęska: Memory as Burden and Liberation. Germans and their Nazi Past (1945-2010). Translated by Marta Skowrońska. 2015.

Bd./Vol. 11 Thomasz Szarota: On the Threshold of the Holocaust. Anti-Jewish Riots and Pogroms in Occupied Europe. Warsaw - Paris - The Hague - Amsterdam Antwerp - Kaunas. Translated by Tristan Korecki. 2015.

Bd./Vol. 12 Anna Wolff-Powęska / Piotr Forecki (eds.): World War II and Two Occupations. Dilemmas of Polish Memory. Translated by Marta Skowrońska and Blanka Zahorjanova. 2016.

Bd./Vol. 13 Elżbieta Katarzyna Dzikowska / Agata Handley / Piotr Zawilski (eds.): The Great War. Insights and Perspectives. 2016.

Bd./Vol. 14 Jerzy Jedlicki: A Degenerate World. Translated by Tristan Korecki. Edited by Elena Rozbicka. 2016.

Bd./Vol. 15 Miroslaw Matyja: Zwischen Krieg und Hoffnung. Internierung der 2. polnischen Infanterieschützen-Division in der Schweiz 1940-45. 2016.

Bd./Vol. 16 Adam Leszczyński: Leap into Modernity - Political Economy of Growth on the Periphery, 1943-1980. 2017.

Bd./Vol. 17 Antoine Marès / Wojciech Prażuch / Inga Kawka (eds.) : Les exilés polonais en France et la réorganisation pacifique de l'Europe (1940-1989). 2017. 
Bd./Vol. 18 Dominika Gortych / Guido Hinterkeuser / Łukasz Skoczylas: Erinnerungsimplantate - Der (Wieder-)Aufbau der Schlösser in Posen und Berlin im interdisziplinären Vergleich. Unter Mitwirkung von Karsten Holste. 2017.

Bd./Vol. 19 Elżbieta Katarzyna Dzikowska / Agata G. Handley / Piotr Zawilski (eds.): Beyond the Trenches - The Social and Cultural Impact of the Great War. 2017.

Bd./Vol. 20 Marcin Zaremba: Communism - Legitimacy - Nationalism. Nationalist Legitimization of the Communist Regime in Poland. 2019

Bd./Vol. 21 Klaus Bachmann: Genocidal Empires. German Colonialism in Africa and the Third Reich. Edited by Barbara Kurowska. 2018.

Bd./Vol. 22 Krzysztof Trybuś / Michael Düring / Maciej Junkiert (Hrsg.): Polen und Deutsche in Europa. Polacy i Niemcy w Europie. Beiträge zur internationalen Konferenz, 16. und 17. November 2015, Poznań. Tom podsumowujący międzynarodową konferencję, 16 i 17 listopada 2015, Poznań. 2018.

Bd./Vol. 23 Monika Jaglarz / Katarzyna Jaśtal (Hrsg.): Bestände der ehemaligen Preußischen Staatsbibliothek zu Berlin in der Jagiellonen-Bibliothek. Forschungsstand und -perspektiven. 2018.

Bd./Vol. 24 Zuzanna Bogumił / Małgorzata Głowacka-Grajper: Milieux de mémoire in Late Modernity. Local Community, Religion and Historical Politics. 2019.

www.peterlang.com 